\title{
CARACTERIZAÇÃO FÍSICO-QUÍMICA E FOTODINÂMICA DE FOTOSSENSIBILIZADORES: EFEITO DA MODIFICAÇÃO QUÍMICA PARA AUMENTAR A SOLUBILIDADE EM MEIO AQUOSO
}

\author{
JOYCE LAURA DA SILVA GONÇALVES
}

Tese apresentada ao Instituto de Química de São Carlos da Universidade de São Paulo como parte dos requisitos para obtenção do título de Doutor em Ciências.

Área de concentração: Química Analítica e Inorgânica

Orientador: Prof. Dr. Hidetake Imasato

Co-orientadora: Profa. Dra. Janice Rodrigues Perussi

São Carlos

2015 
Autorizo a reprodução e divulgação total ou parcial deste trabalho, por qualquer meio convencional ou eletrônico para fins de estudo e pesquisa, desde que citada a fonte.

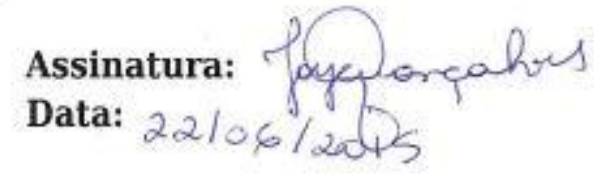

\section{Gonçalves, Joyce Laura da Silva}

Caracterização físico-química e fotodinâmica de fotossensibilizadores: efeito da modificaçăo química para aumentar a solubilidade em meio aquoso. / Joyce Laura da Silva Gonçalves. - São Carlos, 2015.

$132 \mathrm{f}$.

Tese (Doutorado em Química Analítica e Inorgânica) - Instituto de Química de São Carlos / Universidade de São Carlos, 2015.

Ediçäo revisada

Orientador: Prof. Dr. Hidetake Imasato

Coorientadora: Profa. Dra. Janice Rodrigues Perussi

1. Fototerapia. 2. Fotossensibilizador. 3. Hidrossolubilidade. 4. Planejamento fatorial. I. Título. 
"Quem avança confiante na direção de seus sonhos e se empenha em viver a vida que imaginou, encontra um sucesso inesperado em seu dia a dia." 
Aos meus pais Antonio e Maria, pois eles são a fonte incessante e inesgotável que restauram as minhas forças: meu porto seguro em todos os momentos. 


\section{AGRADECIMENTOS}

Ao professor Dr. Hidetake Imasato, pela confiança em mim depositada e oportunidade concedida além de sua incansável dedicação, paciência e atenção despendidas durante a orientação deste trabalho.

À professora Dra. Janice Rodrigues Perussi, por sua co-orientação, e por seus exemplos profissionais e humanos que guardarei carinhosamente na memória.

Aos professores Dr. Kleber Thiago de Oliveira e Dr. Anderson Orzari Ribeiro por fornecer os compostos estudados no presente trabalho.

À professora Dra. Carla Cristina Schimitt Cavalheiro por permitir o uso dos equipamentos do Laboratório de Fotoquímica e Dra. Alessandra Poli pelas ricas discussões sobre este trabalho.

À “Craudia” por me acolher como filha em São Carlos, sua sinceridade hilária, cafés divertidos e contribuições nas metodologias e escrita desta tese.

Aos meus colegas de grupo Anna Cecília, Lucas, Thayz, Alex, Adriel, Yara, Milene, Larissa e Marília pelo apoio e ótimo convívio diário.

Ao pessoal das secretarias Veroneide, Claudia, Gislei, Silvia, Andréia e Gustavo pela simpatia, atenção e pelo excelente atendimento.

Aos meus pais, Antonio e Maria, pelo amor, carinho, compreensão e incentivo além do apoio financeiro. Agradeço ainda pela dádiva da vida, por seus ensinamentos e a confiança em mim depositada ao longo de todos esses anos.

Ao meu noivo Paulo, grande incentivador desta minha conquista, por seu amor, dedicação e companheirismo. Agradeço ainda a família dele, por me receberem tão carinhosamente em suas vidas.

Aos meus irmãos Márcio e Sandra e meus cunhados Adriana e Tiago por entenderem os meus momentos de ausência, e aos meus sobrinhos Tiago, Gabriela e Maria Clara, por sua alegria.

Ao Silvano por sua "malvadeza divertida", por aguentar minhas infindáveis crises de existência e, sobretudo pela amizade incondicional além de sua contribuição neste trabalho.

À Andressa Pilonetto e Christiane S. M Kolc por marcarem importante presença na minha vida acadêmica.

À USP pela oportunidade e á Capes pela bolsa de doutorado concedida.

A Deus por me presentear com uma vida repleta de realizações e oportunidades, me dar forças para superar os obstáculos que encontrei nos caminhos que escolhi e principalmente por ter colocado cada uma destas pessoas maravilhosas em minha vida. 


\section{RESUMO}

A hidrofobicidade e a estrutura planar do orbital $\pi$ estendido de fotossensibilizadores do tipo clorina e hipericina podem favorecer a agregação destes compostos em meio aquoso. Esta agregação pode reduzir a eficiência fotodinâmica e a aplicabilidade destes compostos em diagnósticos e na Terapia fotodinâmica. Uma estratégia para minimizar esta limitação é a modificação destas moléculas pela inserção de grupos hidrofílicos. Neste trabalho foram utilizadas técnicas espectroscópicas para caracterizar as propriedades físico-químicas e fotodinâmicas de derivados de clorina (CHL), e hipericina (HY) obtidos por meio de inserções dos grupos hidrofílicos trizma e glucamina, respectivamente: Clorina-Trizma (CHL-T) e Hipericina Glucamina (HY-G). Os resultados mostraram que estas modificações estruturais aumentaram em até $20 \%$ a solubilidade destes compostos em meio aquoso. No entanto, devido à solubilidade parcial dos fotossensibilizadores na ausência de cargas elétricas foram identificados agregados do tipo $\mathrm{H}$ em meio ácido, neutro e na presença de íons em solução aquosa. Tais agregados foram solubilizados em meio alcalino e por microambientes micelares dos surfactantes CTAB, SDS e Tween 20. Os agregados do tipo H acarretaram ainda na redução da constante de velocidade de fotobranqueamento e da formação de oxigênio singleto dos fotossensibilizadores em meio aquoso. Contudo, as clorinas foram cerca de 15 vezes mais eficientes do que a hipericinas na geração deste radical citotóxico. A análise sistemática do potencial fotodinâmico dos fotossensibilizadores em células VERO e HUVEC (não tumorais) e HEp-2 (tumoral) foi realizada por meio de um planejamento fatorial combinando-se a concentração, tempo de acumulação do fotossensibilizador no interior da célula e a dose de luz. Esta análise mostrou que o tempo de acumulação do fotossensibilizador é um parâmetro significante para se erradicar seletivamente as células cancerígenas. Ao contrário das células não tumorais, nas células HEp-2 a quantidade de fotossensibilizador acumulado foi proporcional à lipoficilidade dos fotossensibilizadores. A análise quimiométrica resultou ainda em um modelo matemático para a estimativa dos valores da concentração inibitória média que foi validada por meio de comparação estatística com os valores experimentais determinados para os fotossensibilizadores. As hipericinas foram mais fototóxicas para as células tumorais do que as clorinas. Nas células não tumorais os derivados foram menos citotóxicos, sugerindo o uso destes compostos para a inativação seletiva de células tumorais. Todas essas características permitem que os compostos sejam empregados como fotossensibilizadores em diagnósticos e tratamentos fotodinâmicos.

Palavras-chave: fotossensibilizador, hidrossolubilidade e planejamento fatorial. 


\begin{abstract}
The hydrophobicity and planar structure of $\pi$ extended orbital of photosensitizers like chlorine and hypericin may favor the aggregation of these compounds in aqueous medium. This aggregation can reduce their photodynamic efficiency and applicability in Photodynamic Therapy and diagnosis. A strategy to minimize this limitation is the modification of these molecules by the inclusion of hydrophilic groups. In this study spectroscopic techniques were used to characterize the physical-chemistry and photodynamic properties of chlorin (CHL) and hypericin (HY) derivatives obtained by insertion of trizma glucamine and hydrophilic groups, respectively: Trizma-Chlorin (CHL-T) and glucamine Hypericin (HY-G). The results showed that these structural modifications increased by $20 \%$ the solubility of these compounds in an aqueous medium. However, due to partial solubility of the photosensitizers in electric charges absence, $\mathrm{H}$-aggregates were found in acid, neutral and ions presence in aqueous solution. These aggregates were solubilized by alkaline medium and micelar microenvironments of CTAB, SDS and Tween 20. H-aggregates were also responsible for the minor photobleaching rate constant and singlet oxygen formation by photosensitizers in an aqueous medium. Although, chlorins were about 15 times more efficient than hypericins on the singlet oxygen generation. The systematic analysis of photosensitizers photodynamic potential in Vero and HUVEC (non-tumor cells) and HEp-2 (tumor cells) was done using a factorial design combining the concentration of the photosensitizer, accumulation time of it into the cell and light doses. This analysis showed that the photosensitizer accumulation time is a significant parameter to eradicate selectively tumor cells. In contrast to non-tumor cells, in HEp-2 cells the accumulation rate was proportional of the lipophylicity of photosensitizer. The chemometric analysis resulted also in a mathematical model to estimate the half inhibitory concentration values. It had been statistical validated by comparing the experimental values determined for the photosensitizers. The hypericins have been more phototoxic to tumor cells than chlorines. In non-tumor cells derivatives were more cytotoxic than original compounds suggesting the use of these compounds for the selective inactivation of tumor cells. All these characteristics allow the use of these compounds as photosensitizers in photodynamic diagnostics and treatments.
\end{abstract}

Key-words: photosensitizer, water solubility and factorial design. 


\section{LISTA DE FIGURAS}

Figura 1: Diagrama de Jablonski: processos fotofísicos presentes na TFD. 21

Figura 2- Estrutura molecular genérica das clorinas. 25

Figura 3- Estrutura molecular da hipericina (HY) 28

Figura 4- Representação gráfica da formação de agregados do tipo H e J para moléculas com orbitais $\pi$ estendidos e seus respectivos espectros de absorção. 32

Figura 5- Estrutura molecular da (a) Clorina (CHL) e (b) Clorina Trizma (CHL-T). ... 37 Figura 6- Estrutura molecular da (a) Hipericina (HY) e (b) Hipericina Glucamina (HYG). 38

Figura 7: Espectros de absorção (a) CHL e (b) CHL-T em DMSO e tampão fosfato de sódio $2,0 \times 10^{-2} \mathrm{~mol} \mathrm{~L}^{-1}, \mathrm{pH} 7,0$. 52

Figura 8: Espectros de absorção da (a) HY e (b) HY-G em DMSO e tampão fosfato de sódio $2,0 \times 10^{-2} \mathrm{~mol} \mathrm{~L}^{-1}, \mathrm{pH} \mathrm{7,0.}$. 53

Figura 9: Espectros de emissão de fluorescência dos fotossensibilizadores em DMSO para (a) CHL e CHL-T e (b) HY e HY-G. Concentração dos fotossensibilizadores $1,7 \times 10^{-7} \mathrm{~mol} \mathrm{~L}^{-1}$ 55

Figura 10: Espectro de absorção em DMSO no período de 180 dias para (a) CHL, (b) CHL-T e (c) HY e (d) HY-G.

Figura 11: Espectros de absorção de (a) CHL, (b) CHL-T e (c) HY e (d) HY-G em função da concentração de $\mathrm{NaCl}, \mathrm{pH} 7,0$. Concentração do fotossensibilizadores $4,5 \times 10^{-6} \mathrm{~mol} \mathrm{~L}^{-1}$ 59

Figura 12: Absorbância em $\lambda$ em função concentração dos fotossensibilizadores, em tampão fosfato de sódio $2,0 \times 10^{-2} \mathrm{~mol} \mathrm{~L}^{-1}$ e $\mathrm{pH} 7,0(\lambda=690 \mathrm{~nm}$ para $\mathrm{CHL}, 680 \mathrm{~nm}$ para CHL-T e 556nm para HY e HY-G).

Figura 13: Espectros de emissão de fluorescência de soluções em DMSO de (a) CHL, (b) CHL-T, (c) HY e (d) HY-G em função da porcentagem de água em solução. (CHL e CHL-T $\lambda_{\text {ex }}=610 \mathrm{~nm}$ e HY e HY-G $\lambda_{\text {ex }}=545 \mathrm{~nm}$ )

Figura 14: Fluorescência integrada de (a) CHL e CHL-T e (b) HY e HY-G em função da porcentagem de água em solução. 
Figura 15: Espectros de absorção da (a) CHL e (b) CHL-T em função do pH em solução de fosfato de sódio $2,0 \times 10^{-2} \mathrm{~mol} \mathrm{~L}^{-1}$. (Fotossensibilizadores $6,5 \times 10^{-6} \mathrm{~mol} \mathrm{~L}^{-1}$ ). 66

Figura 16: Absorbância em 368 nm para (a) CHL e (b) CHL-T em função do pH. (Tampão fosfato de sódio $2,0 \times 10^{-2} \mathrm{~mol} \mathrm{~L}^{-1}$ ).

Figura 17: (a) Componentes da deconvolução dos espectros de absorção da CHL (fosfato de sódio $2,0 \times 10^{-2} \mathrm{~mol} \mathrm{~L}^{-1}$ ) e (b) contribuições das frações destas espécies existentes no equilíbrio em função do $\mathrm{pH}$.

Figura 18: Espectros de emissão de fluorescência da (a) CHL e (b) CHL-T em função do pH. (Tampão de fosfato de sódio $2,0 \times 10^{-2} \mathrm{~mol} \mathrm{~L}^{-1}$ e $\lambda_{\mathrm{ex}}=610 \mathrm{~nm}$ ). 70

Figura 19: Espectros de absorção da (a) HY e (b) HY-G em solução de fosfato de sódio $2,0 \times 10^{-2} \mathrm{~mol} \mathrm{~L}-1$ em função do pH. (HY 5,0 ×10 $0^{-6} \mathrm{~mol} \mathrm{~L}^{-1}$ e HY-G $\left.1,1 \times 10^{-5} \mathrm{~mol} \mathrm{~L}^{-1}\right) .71$ Figura 20: Absorbância em 600 nm para (a) HY e (b) HY-G em função do pH. (Tampão fosfato de sódio $2,0 \times 10^{-2} \mathrm{~mol} \mathrm{~L}^{-1}$ ). 73

Figura 21: (a) Componentes da deconvolução dos espectros de absorção da HY-G (fosfato de sódio $2,0 \times 10^{-2} \mathrm{~mol} \mathrm{~L}^{-1}$ ) e (b) contribuições das frações destas espécies existentes no equilíbrio em função do $\mathrm{pH}$. 74

Figura 22: Espectros de emissão de fluorescência da (a) HY e (b) HY-G em função do pH. (Tampão de fosfato de sódio $2,0 \times 10^{-2} \mathrm{~mol} \mathrm{L-1} \mathrm{e} \lambda \mathrm{ex}=545 \mathrm{~nm}$ ). 75

Figura 23- Espectros de absorção da CHL-T em função da concentração dos

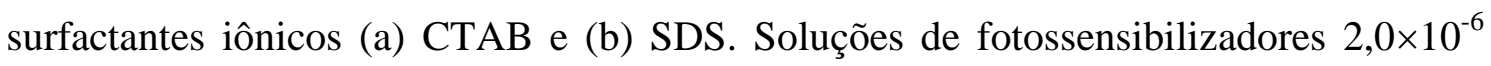
mol L $\mathrm{L}^{-1}$ em tampão fosfato de sódio $2,0 \times 10^{-2} \mathrm{~mol} \mathrm{~L}^{-1}$ e $\mathrm{pH} 7,0$. 77

Figura 24-Espectros de absorção da HY-G em função da concentração dos surfactantes iônicos (a) CTAB e (b) SDS. Soluções de HY-G 5,0×10-6 $\mathrm{mol} \mathrm{L}^{-1}$ em tampão fosfato de sódio $2,0 \times 10^{-2} \mathrm{~mol} \mathrm{~L}^{-1}$ e $\mathrm{pH} 7,0$ 79

Figura 25-Espectros de absorção da (a) CHL-T e (b) HY-G em função da concentração do surfactante não iônico Tween 20. Soluções de fotossensibilizadores $2,0 \times 10^{-6} \mathrm{~mol} \mathrm{~L}-1$ em tampão fosfato de sódio $2,0 \times 10^{-2} \mathrm{~mol} \mathrm{L-1} \mathrm{e} \mathrm{pH} \mathrm{7,0.}$ 80

Figura 26: Espectros de absorção e fluorescência dos FS $1,5 \times 10^{-6} \mathrm{~mol} \mathrm{~L}^{-1}$ em DMSO irradiados por até 3600s. (a) e (b) CHL-T empregando LED vermelho $660 \pm 10 \mathrm{~nm}$ com irradiância de $26,7 \mathrm{~mW} \mathrm{~cm}^{-2}$ e (c) e (d) HY-G empregando LED amarelo 590 $\pm 10 \mathrm{~nm}$ irradiância de $15,8 \mathrm{~mW} \mathrm{~cm}^{-2}$. 81 
Figura 27: Porcentagem dos fotossensibilizadores remanescentes em solução após a irradiação com LED de comprimento de onda adequado em função do tempo em (a) DMSO e (b) tampão fosfato de sódio $2,0 \times 10^{-2} \mathrm{~mol} \mathrm{~L}^{-1} \mathrm{pH} 7,0$.

Figura 28- Intensidade de fluorescência em $\lambda$ fixo em função da concentração de (a) CHL e CHL-T e (b) HY e HY-G em tampão fosfato de sódio $2,0 \times 10^{-2} \mathrm{~mol} \mathrm{~L}^{-1}$ acrescido de $0,001 \%$ de Tween 20 ( $\lambda_{\text {ex }}=610 \mathrm{~nm}$ para CHL e CHL-T e $545 \mathrm{~nm}$ para HY e HY-G).

Figura 29- Espectro de absorção do ácido úrico $1,20 \times 10^{-4} \mathrm{~mol} \mathrm{~L}^{-1}$ em solução em tampão fosfato de sódio $2,0 \times 10^{-2} \mathrm{~mol} \mathrm{~L}^{-1} \mathrm{pH} 7,0$ acrescido de $0,001 \%$ de Tween $20 \ldots 87$

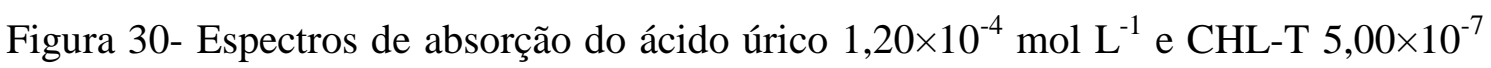
mol L ${ }^{-1}$ em função do tempo de irradiação. Solução em tampão fosfato de sódio $2,0 \times 10^{-}$ ${ }^{2}$ mol L ${ }^{-1}$ pH 7,0 contendo 0,001\% de Tween 20, irradiado com LED $660 \mathrm{~nm}, \mathrm{I}=27,6$ $\mathrm{mW} \mathrm{cm} \mathrm{cm}^{-2}$. 88

Figura 31- Valores de AF em função da concentração de (a) CHL e CHL-T e (b) HY e HY-G. AF $\left(\mathrm{m}^{2} \mathrm{~J}^{-1}\right)$ calculados através da Equação $4(\Delta \mathrm{t}=300 \mathrm{~s})$.

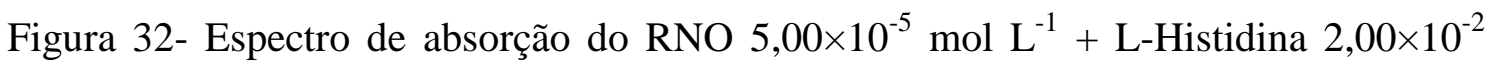
mol L $\mathrm{L}^{-1}$ em solução de tampão fosfato de sódio $2,0 \times 10^{-2} \mathrm{~mol} \mathrm{~L}^{-1} \mathrm{pH} \mathrm{7,0}$ acrescido de $0,001 \%$ de Tween 20 .

Figura 33- Valores da constante de velocidade de decomposição do RNO em função da concentração dos fotossensibilizadores.

Figura 34- Espectros de absorção do DPBF 5,00×10 ${ }^{-5} \mathrm{~mol} \mathrm{~L}^{-1}$ em etanol. 94

Figura 35- (a) Espectros de emissão de fluorescência da CHL-T em etanol em função da concentração e (b) curva analítica da CHL-T obtida a partir das intensidades de fluorescência integradas em função da concentração $\left(\lambda_{\text {ex }}=610 \mathrm{~nm}\right)$.

Figura 36- Acumulação dos fotossensibilizadores em células HEp-2 normalizada pela concentração de proteína em função do tempo de incubação $(n=3)$.

Figura 37- Acumulação dos fotossensibilizadores em células (a) Vero e (b) HUVEC normalizadas pela concentração de proteína em função do tempo de incubação $(n=3)$.

Figura 38- Índice de sobrevivência para as linhagens celulares HEp-2, Vero e HUVEC em função da dose de luz incidida para (a) LED 590 nm e (b) LED 660 nm. (n=6) ... 102 
Figura 39- Diagrama de Pareto para os efeitos principais e secundários dos fotossensibilizadores na linhagem celular HEp-2. * valores não significativos estatisticamente (teste t de Student, 95\% de confiança).............................................. 105

Figura 40- Diagrama de Pareto para os efeitos principais e secundários dos fotossensibilizadores na linhagem celular Vero. * valores não significativos estatisticamente (teste t de Student, 95\% de confiança)........................................... 106 Figura 41- Diagrama de Pareto para os efeitos principais e secundários dos fotossensibilizadores na linhagem celular HUVEC. * valores não significativos estatisticamente (teste t de Student, 95\% de confiança). 107

Figura 42- Valores de $\mathrm{IC}_{50}$ experimentais e teóricos em função da dose de luz para (a) CHL e CHL-T e (b) HY e HY-G para a linhagem celular HUVEC. 113 


\section{LISTA DE TABELAS}

Tabela 1- Propriedades dos surfactantes utilizados neste estudo.

Tabela 2- Matriz de planejamento aplicado nos experimentos de citotoxicidade dos fotossensibilizadores para o planejamento fatorial $2^{3}$. 48

Tabela 3- Concentrações molares dos fotossensibilizadores empregados no

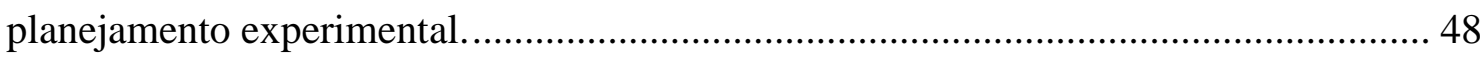

Tabela 4- Parâmetros fotofísicos dos fotossensibilizadores. .......................................... 56

Tabela 5- Valores de coeficiente de absortividade molar para os fotossensibilizadores em DMSO. 58

Tabela 6- Valores de concentração salina crítica para os fotossensibilizadores. 59

Tabela 7- Coeficientes de partição calculados para os fotossensibilizadores $1,43 \times 10^{-5}$ mol L $\mathrm{L}^{-1}$ utilizando-se o sistema previamente saturado de 1-octanol/ tampão fosfato de sódio $2,0 \times 10^{-2} \mathrm{~mol} \mathrm{~L}^{-1}, \mathrm{pH} \mathrm{7,0}$.

Tabela 8- Valores de coeficiente de absortividade molar para os fotossensibilizadores em tampão fosfato de sódio $2,0 \times 10^{-2} \mathrm{~mol} \mathrm{~L}^{-1}, \mathrm{pH} 7,0$.

Tabela 9- Valores de \% de água críticos para solubilização dos fotossensibilizadores. 65 Tabela 10- Valores de constante de fotobranqueamento para os fotossensibilizadores em DMSO e meio aquoso.

Tabela 11- Valores de constante de velocidade de atividade fotodinâmica para os fotossensibilizadores 90

Tabela 12- Valores de constante de velocidade de formação de oxigênio singleto para os fotossensibilizadores

Tabela 13- Valores de rendimento quântico de formação de oxigênio singleto para os fotossensibilizadores utilizando DPBF como sequestrador químico.

Tabela 14- Valores de rendimento quântico de fluorescência para fotossensibilizadores descritos na literatura.

Tabela 15- Parâmetros analíticos da curva padrão de fluorescência para os fotossensibilizadores 98

Tabela 16- Planejamento fatorial $2^{3}$ completo para avaliação da citoxicidade dos fotossensibilizadores na linhagem celular HEp-2. 
Tabela 17- Valores de $\mathrm{IC}_{50}\left(\mathrm{nmol} \mathrm{L} \mathrm{L}^{-1}\right)$ para os fotossensibilizadores para a linhagem HEp-2 em função da dose de luz. Tempo de incubação 2 h. Clorinas irradiadas com LED $660 \mathrm{~nm}, \mathrm{I}=27,6 \mathrm{~mW} \mathrm{~cm}{ }^{-2}$ e hipericinas com LED $590 \mathrm{~nm}, \mathrm{I}=15,8 \mathrm{~mW} \mathrm{~cm} \mathrm{~m}^{-2}$ $(n=3)$.

Tabela 18- Valores de $\mathrm{IC}_{50}\left(\mathrm{nmol} \mathrm{L}{ }^{-1}\right)$ para os fotossensibilizadores para a linhagem Vero em função da dose de luz. Tempo de incubação $2 \mathrm{~h}$. Clorinas irradiadas com LED $660 \mathrm{~nm}, \mathrm{I}=27,6 \mathrm{~mW} \mathrm{~cm}^{-2}$ e hipericinas com LED $590 \mathrm{~nm}, \mathrm{I}=15,8 \mathrm{~mW} \mathrm{~cm}^{-2} \quad(\mathrm{n}=3)$.

Tabela 19- Valores de $\mathrm{IC}_{50}\left(\mathrm{nmol} \mathrm{L} \mathrm{L}^{-1}\right)$ para os fotossensibilizadores para a linhagem HUVEC em função da dose de luz. Tempo de incubação $2 \mathrm{~h}$. Clorinas irradiadas com LED $660 \mathrm{~nm}, \mathrm{I}=27,6 \mathrm{~mW} \mathrm{~cm}^{-2}$ e hipericinas com LED $590 \mathrm{~nm}, \mathrm{I}=15,8 \mathrm{~mW} \mathrm{~cm}{ }^{-2}$ $(\mathrm{n}=3)$.

Tabela 20- Efeitos calculados para o planejamento fatorial $2^{3}$ para a HY-G na linhagem celular HUVEC.

Tabela 21-Valores de $\mathrm{IC}_{50}$ experimentais e teóricos $\left(\mathrm{nmol} \mathrm{L}{ }^{-1}\right)$ em função da dose de luz para os fotossensibilizadores nas linhagens celulares HEp-2 e VERO. 114 


\section{LISTA DE ABREVIAÇÕES E SIGLAS}

AU- ácido úrico

CHL- Clorina

CHL-T- Clorina Trizma

CTAB- hexadeciltrimetilamônio

DMSO- dimetilsulfóxido

DPBF- 1,3-Difenilisobenzofurano

ERO- espécie(s) reativa(s) de oxigênio

HEp-2- linhagem celular epitelial tumoral de laringe humana

HUVEC- linhagem celular endotelial não tumoral de cordão umbilical humano

HY- Hipericina

HY-G- Hipericina Glucamina

$\mathrm{IC}_{50^{-}}$concentração inibitória média

IS- índice de sobrevivência

LED- Ligth Emitting Diode (diodos emissores de luz)

$\log$ P- logaritmo do coeficiente de partição

MA- microambiente(s)

MTT-3-4,5-dimetiltiazol-2-il-2,5-difenil brometo de tetrazolio

RNO- p-nitroso dimetilanilina

SDS- dodecil sulfato de sódio

TFD- Terapia Fotodinâmica

Tween 20- polioxietilenosorbitan

UV-Vis- ultravioleta e visível

VERO-linhagem celular epitelial não tumoral de rim de macaco 


\section{SUMÁRIO}

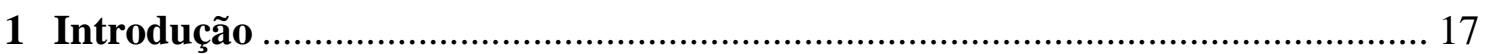

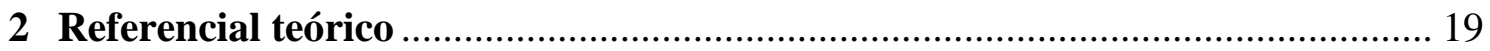

2.1 Tratamentos e diagnósticos fotodinâmicos: princípios e aplicações .................. 19

2.1.1 Processos fotofísicos envolvidos nas aplicações dos fotossensibilizadores ......... 20

2.1.2 A janela terapêutica e os sistemas óticos para fotossensibilização ........................ 22

2.2 Fotossensibilizadores: propriedades e aplicações ......................................... 23

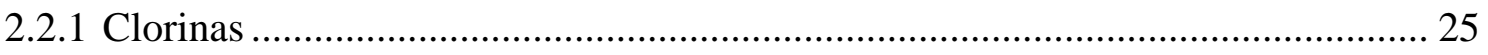

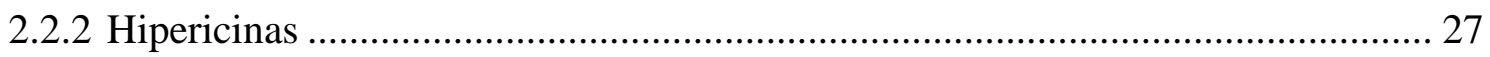

2.3 Avaliação da eficiência dos fotossensibilizadores ............................................ 29

2.3.1 Formação de oxigênio singleto em ambientes micelares .................................... 29

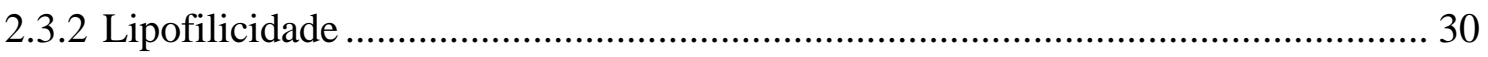

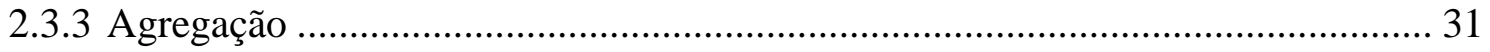

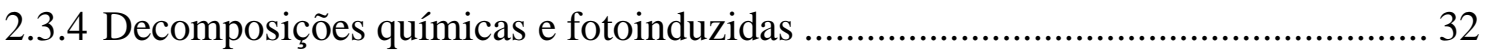

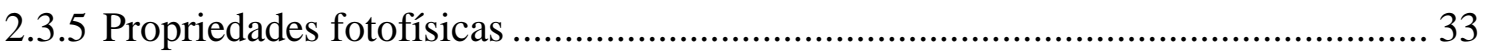

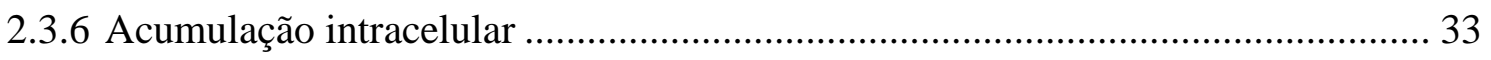

2.3.7 Ensaios citotóxicos em culturas celulares e o planejamento fatorial .................... 34

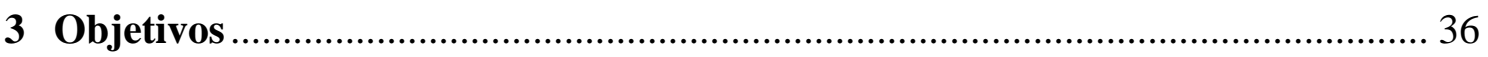

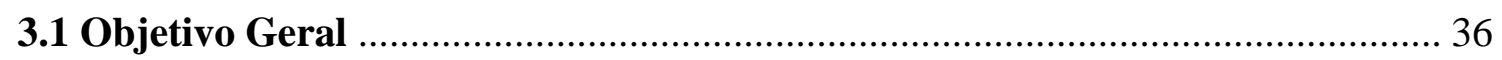

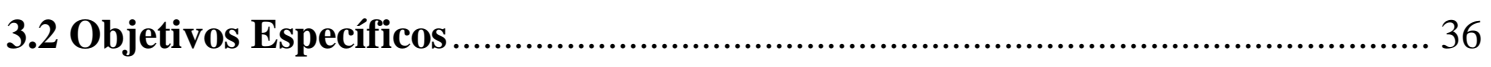

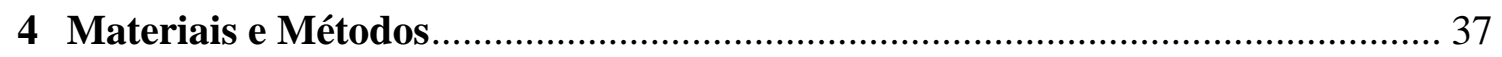

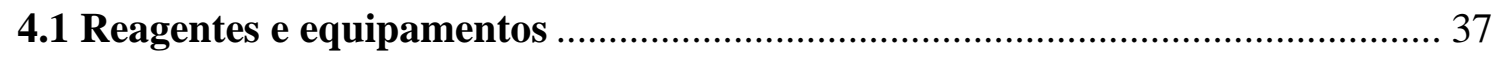

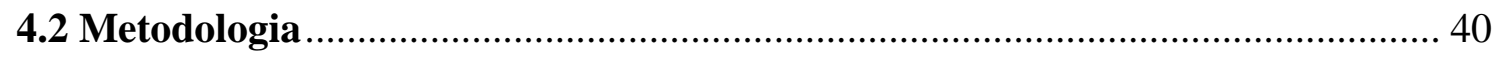

4.2.1 Determinação do rendimento quântico de fluorescência $(\Phi F)$ e do tempo de vida

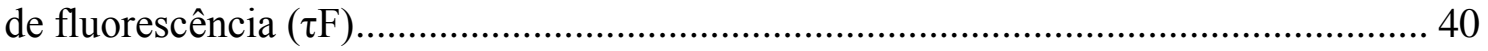

4.2.2 Determinação dos coeficientes de partição dos fotossensibilizadores $(\log \mathrm{P})$...... 41 


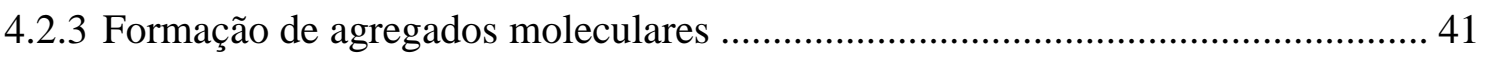

4.2.4 Influência do pH e da força iônica no meio reacional ........................................... 42

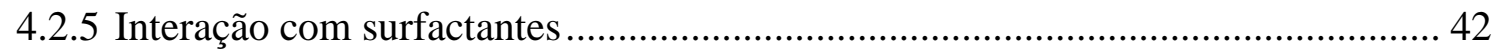

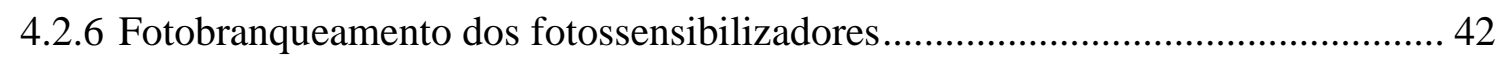

4.2.7 Estimativa do rendimento quântico de geração de oxigênio singleto pela oxidação do ácido úrico.

4.2.8 Estimativa do rendimento quântico de geração de oxigênio singleto pela oxidação do RNO...

4.2.9 Estimativa do rendimento quântico de geração de oxigênio singleto pela oxidação do DPBF. . .44

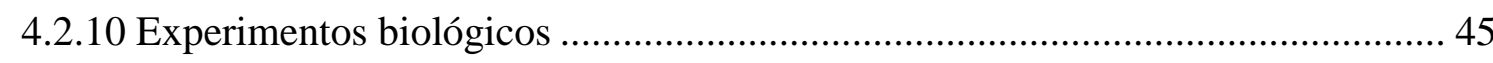

4.2.10.1 Ação fotodinâmica sobre células de mamíferos ............................................ 45

4.2.10.2 Acumulação intracelular de fotossensibilizadores ........................................... 46

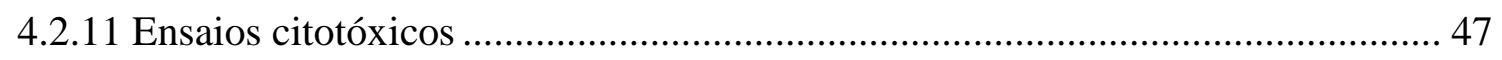

4.2.11.1 Ensaios na presença de planejamento fatorial ........................................... 47

4.2.11.2 Ensaios na ausência de planejamento fatorial ........................................... 49

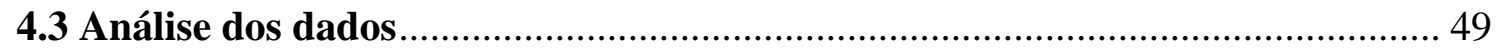

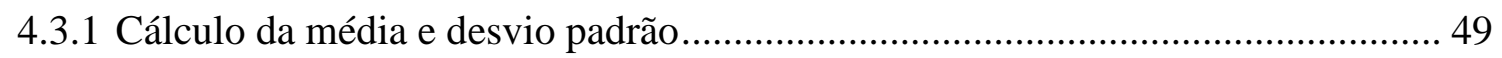

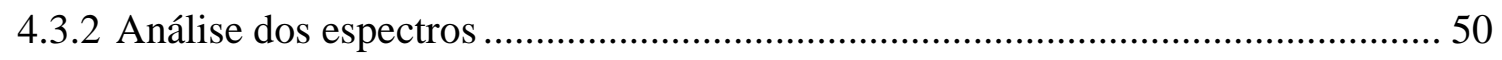

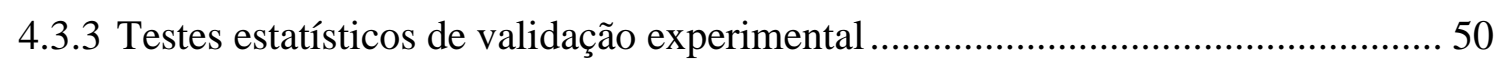

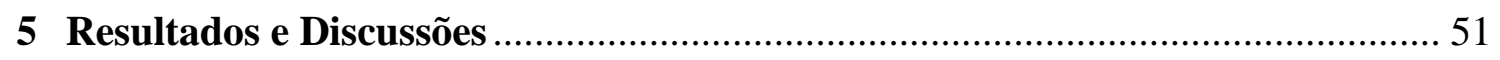

5.1 Caracterização espectroscópica dos fotossensibilizadores.............................. 51

5.2 Estudos da estabilidade dos fotossensibilizadores em função do tempo de

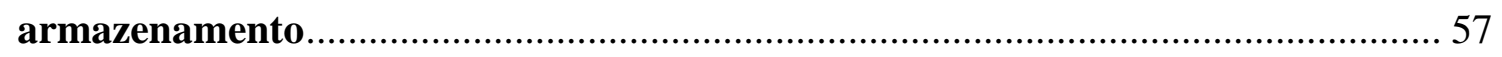

5.3 Análise da influência da força iônica em solução sobre os fotossensibilizadores .58

5.4 Determinação da constante de partição dos fotossensibilizadores (P).............. 60

5.5 Processo de autoagregação dos fotossensibilizadores........................................ 61

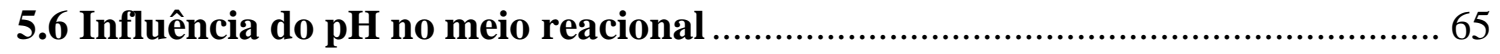

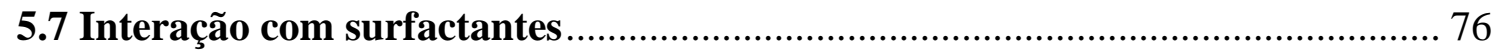


5.9 Determinação da formação de oxigênio singleto pelo método estacionário 85

5.9.1 Avaliação da atividade fotodinâmica dos fotossensibilizadores 87

5.9.2 Determinação do rendimento quântico de geração de oxigênio singleto por DPBF .93

5.10 Experimentos celulares . 96

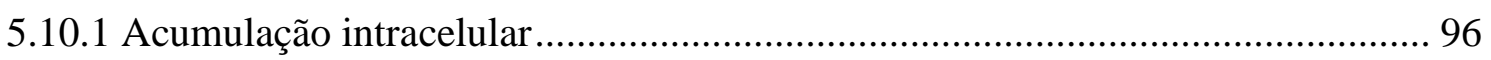

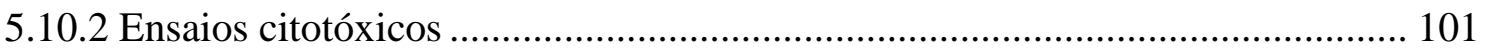

5.10.2.1 Influência da luz incidida sob as culturas celulares..................................... 101

5.10.2.2 Análise de citotoxicidade dos fotossensibilizadores utilizando planejamento

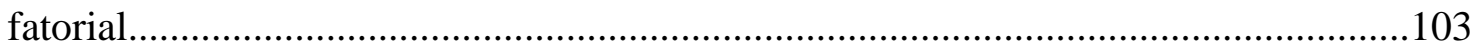

5.10.2.3 Efeito da dose de luz na citotoxicidade dos fotossensibilizadores ............... 108

5.10.2.4 Comparação entre os valores de $\mathrm{IC}_{50}$ experimental e teórico......................... 112

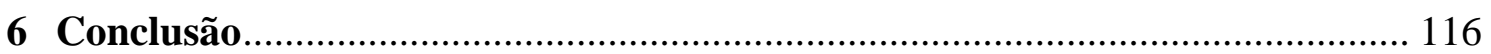

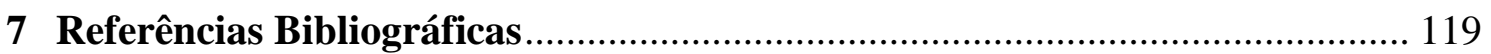




\section{INTRODUÇÃOO}

Os fotossensibilizadores são compostos que possuem em sua estrutura molecular grupos cromóforos que fazem com que estas substâncias tornem-se ativadas pela absorção de radiação eletromagnética (1). O fotossensibilizador no estado excitado pode interagir diretamente com um substrato ou propiciar a formação de oxigênio singleto e/ou de radicais que irão promover a destruição de tecidos biológicos $(2,3)$.

A Terapia Fotodinâmica vem explorando esta propriedade dos fotossensibilizadores na erradicação de tumores e doenças com crescimento desordenado de tecidos, impedimento de proliferação bacteriana, inativação de organismos patogênicos do sangue, esterilização de água e desinfecção e limpeza de superfícies (4). O principal agente citotóxico formado neste processo é o oxigênio singleto $\left({ }^{1} \mathrm{O}_{2}\right)$ que reage com biomoléculas presentes nas membranas biológicas ocasionando a morte celular $(5,6)$. Outra propriedade interessante no estudo destes compostos é o fato de serem usualmente luminescentes, o que possibilita a aplicação destes como sondas em diagnósticos clínicos.

Várias metodologias são descritas na literatura com a finalidade de comparar-se a eficiência fotodinâmica dos fotossensibilizadores (7-11). Contudo, o principal interesse está na capacidade que o composto possui em formar ${ }^{1} \mathrm{O}_{2}$. Uma das metodologias mais empregadas na detecção e quantificação de ${ }^{1} \mathrm{O}_{2}$ tem como base a oxidação de substratos específicos que atuam como sequestradores químicos de ${ }^{1} \mathrm{O}_{2}(7$, 12, 13). Contudo, esta metodologia pode ser limitada pela baixa solubilidade dos sequestradores químicos em meio aquoso. Uma forma de minimizar esse problema nos estudos em fase aquosa tem sido o emprego de microambientes hidrofóbicos que podem ainda retardar o estágio de início do processo de agregação dos fotossensibilizadores.

A agregação dos fotossensibilizadores inviabiliza seu uso como fármaco, uma vez que, normalmente, são introduzidos no paciente por via intravenosa. Desta forma, sua agregação poderia provocar o entupimento das veias e até mesmo o óbito do paciente. Tais agregados são diretamente influenciados pelas distribuições de cargas e presença de microambientes no meio reacional.

Além da agregação, outros fatores podem influenciar na potencialidade do fotossensibilizador, tais como decomposição química, interações com componentes sanguíneos, fotobranqueamento, lipofilicidade, rendimento quântico de fluorescência e de formação de ${ }^{1} \mathrm{O}_{2}$, toxicidade, seletividade, etc. 
Concomitantemente às análises físico-químicas, podem ser realizados ensaios com linhagens celulares para avaliar a biocompatibilidade dos fotossensibilizadores (1416). A acumulação intracelular consiste na quantificação do fotossensibilizador que adentrou a estrutura da célula, enquanto que os ensaios citotóxicos são baseados na quantificação da eficiência em inibir a proliferação celular.

De maneira geral, o dano celular causado em ensaios citotóxicos é dependente de vários fatores como tipo de linhagem celular e fotossensibilizador empregados, taxa de incorporação deste composto no interior da célula e dose de luz (17). Em sua maioria, estes ensaios são realizados de forma univariada. No entanto, somente experimentos multivariados possibilitam correlacionar estes fatores e evidenciar as interações significativas (18). 


\section{REFERENCIAL TEÓRICO}

\subsection{Tratamentos e diagnósticos fotodinâmicos: princípios e aplicações}

A Terapia Fotodinâmica (TFD) é uma metodologia seletiva e não invasiva para destruição de células e tecidos indesejáveis (4). Esta metodologia caracteriza-se por um conjunto de processos físicos, químicos e biológicos resultantes da ação conjunta de um fotossensibilizador, radiação eletromagnética de comprimento de onda correspondente ao espectro de absorção do fotossensibilizador e oxigênio molecular (19, 20). Separadamente, nenhum destes elementos é tóxico à célula e/ou tecidos.

Apesar dos primeiros relatos sobre esta modalidade de tratamento datar do início do século XX (21), ela só foi clinicamente aprovada no final dos anos 70 para um número seleto de tumores (6). Desde então, o seu uso vem sendo vastamente descrito não apenas na oncologia (22) como também na oftalmologia (23), cardiologia (24), urologia (25), dermatologia (26) e odontologia (27). Outras modalidade de tratamento por TFD são infecções por microrganismos (27-30), bactérias resistentes à antibióticos (31), cepas fúngicas, entre outras.

A principal vantagem da TFD é a acumulação seletiva do fotossensibilizador nas células alvo, seguido da formação de espécies citotóxicas in situ causando a destruição tecidos doentes (32).

As principais limitações desta técnica consistem na dificuldade do tratamento de grandes massas tumorais e a profundidade das lesões em que estes compostos são capazes de atuar, uma vez que a faixa de penetração da luz vermelha em tecidos não é superior a $5-10 \mathrm{~nm}(4)$.

Estas desvantagens têm sido minimizadas em tratamentos oncológicos em que as terapias convencionais (cirurgia, radioterapia e quimioterapia) são associadas à TFD. Além disso, sistemas constituídos de fibras ópticas facilitam o tratamento de tumores internos (33).

Os fotossensibilizadores têm sido utilizados ainda como sonda em diagnósticos clínicos por meio de emissão de fluorescência, e quando complexados a um metal paramagnético, podem atuar como agentes de contraste em imagem por ressonância magnética nuclear. Ambas as técnicas de diagnósticos clínicos são consideradas promissoras pela possibilidade de obtenção de imagens funcionais e não invasivas (34). 
Os diagnósticos por fluorescência consistem em monitorar a intensidade de fluorescência do fotossensibilizador incorporado ao tecido (35). O diagnóstico da doença de Bowen (carcinoma) pode ser realizado pelo acompanhamento da fluorescência emitida pela protoporfirina IX produzida pelo ácido 5-aminolevulínico (ALA), após irradiação da pele com radiação eletromagnética na região visível (370-400 nm) $(36,37)$.

Os diagnósticos por imagens de Ressonância Magnética (IRM) apresentam dados topográficos em três dimensões com alta resolução espacial e informações do tecido em tempo real sem fazer uso de radiação ionizante. Apesar da IRM já apresentar uma enorme potencialidade referente a contraste, permite ainda a utilização de agentes de contraste que aperfeiçoam a visibilidade das imagens, promovendo a diferenciação entre o tumor e os tecidos vizinhos saudáveis(38).

As aplicações clínicas da IRM são amplas, contudo a neurologia é uma das áreas em que ela é mais explorada, principalmente no diagnóstico de tumores. Entretanto, outras doenças degenerativas, inflamatórias ou cardiovasculares podem ser detectadas através desta técnica. Como exemplo clínico cita-se imagens da coluna vertebral onde se visualiza tumores, compressões ou qualquer má formação na coluna. Outro exemplo são imagens da região do abdômen onde pode ser visualizada qualquer lesão ou alteração de estrutura com nitidez de todos os órgãos.

\subsubsection{Processos fotofísicos envolvidos nas aplicações dos fotossensibilizadores}

Os processos fotofísicos envolvidos em diagnósticos por fluorescência e TFD são ilustrados pela interpretação do diagrama de Jablonski (39) (Figura 1). No caso da aplicação em diagnósticos por fluorescência, o fotossensibilizador é previamente excitado e o decaimento da emissão de fluorescência é monitorado (40). Na TFD, posteriormente à excitação do fotossensibilizador há uma interação deste com o oxigênio molecular presente nos tecidos, resultando em espécies reativas que induzem a inviabilização das células (2). 
Figura 1: Diagrama de Jablonski: processos fotofísicos presentes na TFD.

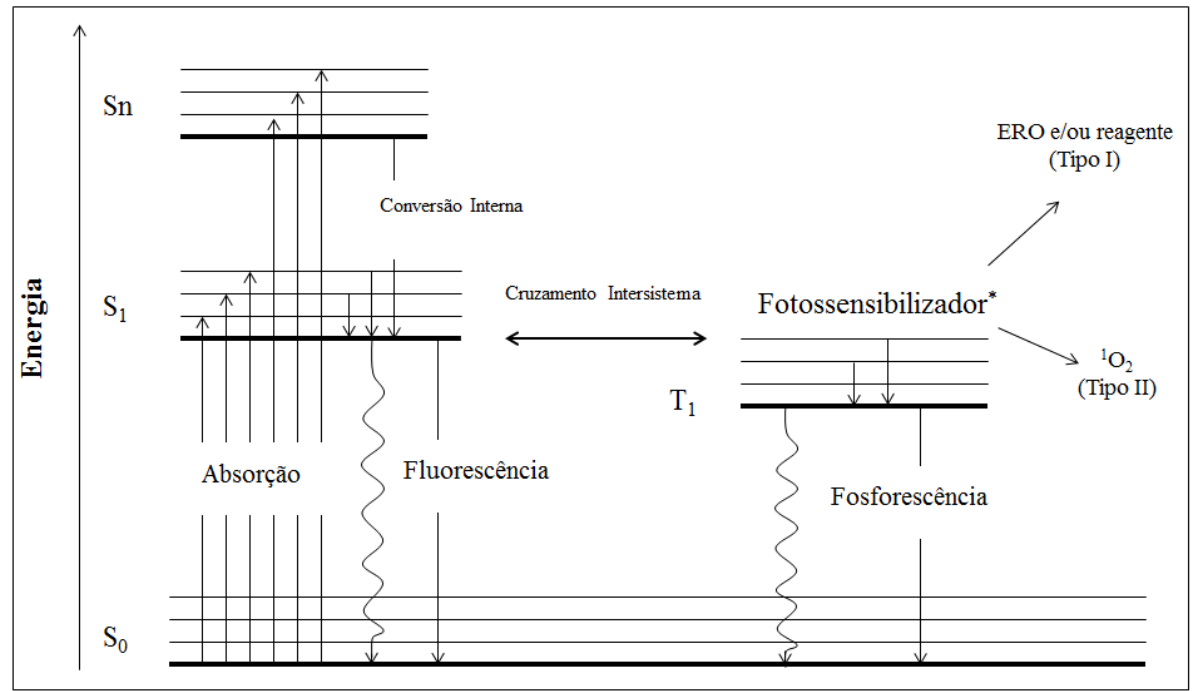

Fonte: Adaptado de Lacowitz (2006), p.5 (39).

Em ambas as situações, o estado eletrônico fundamental do fotossensibilizador é o estado singleto $\left(\mathrm{S}_{0}\right)$. Quando irradiado com luz de comprimento de onda adequado, o fotossensibilizador é promovido para o estado excitado singleto $\left(\mathrm{S}_{\mathrm{n}}\right)$ constituído de vários sub-níveis vibracionais com tempo de vida curto (1-100 ns). Neste estado, o fotossensibilizador perde rapidamente a sua energia por decaimento vibracional indo para o primeiro nível vibracional do $\mathrm{Sn}$, e posteriormente, por conversão interna para o primeiro estado excitado singleto $\left(\mathrm{S}_{1}\right)$. A partir desta etapa, o fotossensibilizador pode sofrer dois tipos de processos distintos: um radiativo e um não radiativo (41).

No processo radiativo, o fotossensibilizador retorna ao estado fundamental $\left(\mathrm{S}_{0}\right)$ emitindo a energia absorvida na forma de fluorescência (mecanismo utilizado em diagnósticos de fluorescência) $(37,39)$. No entanto, o processo não radiativo pode ocorrer promovendo o fotossensibilizador do primeiro estado singleto excitado, por cruzamento intersistema, ao estado tripleto excitado $\left(\mathrm{T}_{1}\right)$. $\mathrm{O}$ decaimento do fotossensibilizador no estado $\mathrm{T}_{1}$ pode ocorrer por perda de calor, emissão de fosforescência ou pela transferência de energia ou de elétrons (41). O maior tempo de vida (microssegundos) do fotossensibilizador no estado $\mathrm{T}_{1}$ possibilita a colisão com outras moléculas, resultando na formação de espécies quimicamente reativas.

O mecanismo de interação entre o fotossensibilizador no estado tripleto excitado com os tecidos pode ocorrer por dois mecanismos distintos: (i) diretamente com o substrato, por reações de transferência de elétrons ou de hidrogênio, gerando espécies reativas de oxigênio (ERO) ou (ii) pela transferência de energia ao oxigênio molecular 
no estado fundamental (oxigênio tripleto) produzindo oxigênio singleto (mecanismo tipo II) (42). Ambos os mecanismos estão presentes em TFD e são capazes de oxidar uma grande variedade de biomoléculas (3).

Sugere-se que existam três mecanismos possivelmente correlacionados e responsáveis pela erradicação do tumor por TDF: (i) diretamente pela geração de ERO e ${ }^{1} \mathrm{O}_{2}$ causando necrose e/ou apoptose celular, (ii) danos na vascularização da região tumoral acarretando na limitação de oxigênio e nutrientes ao tecido e (iii) ativação de resposta imune contra este tipo de radicais $(43,44)$.

\subsubsection{A janela terapêutica e os sistemas óticos para fotossensibilização}

Os diagnósticos e tratamentos fotodinâmicos requerem não apenas a acumulação seletiva do fotossensibilizador nas células alvos, como também que o comprimento de onda de emissão da fonte de radiação eletromagnética seja correspondente ao espectro de absorção do fotossensibilizador (45).

O espalhamento e a absorção de luz por cromóforos endógenos presentes nos tecidos limitam a penetração da luz nos tecidos biológicos. As proteínas e o DNA absorvem na faixa do ultravioleta $(200-350 \mathrm{~nm})$, a melanina em comprimentos de onda entre 200 a $400 \mathrm{~nm}$ e a hemoglobina na região entre 400-600 nm. Acima de $1300 \mathrm{~nm}$ as moléculas de água presentes nos tecidos podem absorver a radiação incidida, reduzindo assim, a penetração da luz nos tecidos (4).

A região restante, compreendida entre $600-800 \mathrm{~nm}$, na qual os tecidos biológicos são relativamente transparentes é denominada janela terapêutica $(19,20)$. Nesta região não há competição de absorção entre os cromóforos endógenos e os fotossensibilizadores, ocorrendo assim, a máxima absorção de irradiação pelos tecidos. A maioria dos estudos clínicos é realizada com luz de comprimentos entre 625 e 633 $\mathrm{nm}$, que permitem maior penetração na pele e ainda devido a possibilidade de absorção desta radiação pelos compostos porfirírnicos. (46).

Morton e colaboradores observaram que a irradiação de comprimento de onda de $635 \mathrm{~nm}$ foi capaz de penetrar na pele em aproximadamente $6 \mathrm{~mm}$, enquanto que a de comprimento de onda entre $400-500 \mathrm{~nm}$ penetrou apenas 1 a $2 \mathrm{~mm}$. A profundidade terapeutica efetiva observada pelos autores foi cerca de 1-3 mm, quando irradiado em 635 nm (45). 
As fontes de irradiação disponíveis para tratamentos fotodinâmicos podem ser do tipo coerentes (lasers) ou não coerentes (lâmpadas de halogênios, tungstênio, ou de diodos emissores). O laser apresenta um comprimento de onda específico, correspondente ao pico de absorção do fotossensibilizador. Sua capacidade de emissão de luz monocromática de alta fluência, associada à precisão do foco, permite tratar seletivamente pequenas lesões com mínimo dano ao tecido e em curto intervalo de tempo (45). Todavia, esse tipo de sistema é de alto custo e requer a presença de um técnico para aplicação e manutenção do sistema (47).

Neste âmbito tem-se utilizado os diodos emissores de luz (do inglês Ligth Emitting Diode- LED) como fontes de irradiação, pois possibilitam a redução dos custos dos procedimentos e facilidade de operação (48). Os LED emitem luz visível através da combinação de dois semicondutores diferentes, os quais possuem excesso ou falta de elétrons. Os elétrons conectam-se sempre que é aplicada tensão sobre a combinação de ambos os semicondutores. A principal vantagem do uso do LED em tratamentos fotodinâmicos é que eles possuem uma banda relativamente grande $( \pm 10$ nm), não ficando restritos a um único comprimento de onda, como é o caso dos lasers.

\subsection{Fotossensibilizadores: propriedades e aplicações}

As características mais relevantes para o uso clínico de um fotossensibilizador são a farmacocinética favorável que propicia o acúmulo seletivo no organismo alvo e a potencialidade na geração de espécies citotóxicas (32). Além disso, o fotossensibilizador ideal deve apresentar as seguintes características (20, 49-51):

(i) composição química constante com alto grau de pureza, atóxico, baixo custo e facilidade de produção em escala industrial;

(ii) elevado coeficiente de absorção em comprimentos de onda na região espectral correspondente à janela terapêutica (600-850 nm) cuja faixa os tecidos apresentam maior penetração de luz;

(iii) alto rendimento quântico de estado tripleto e tempo de vida suficiente para que a reação de transferência de energia para o oxigênio molecular se processe formando o oxigênio singleto;

(iv) ser estável sob irradiação; 
(v) ser solúvel em meio aquoso, todavia contendo grupamentos hidrofóbicos para facilitar a passagem através das membranas celulares e

(vi) não induzir efeitos mutagênicos.

A maioria dos fotossensibilizadores empregados atualmente em TFD são estruturas cíclicas tetrapirrólicas: porfirinóides, clorinas, bacterioclorinas, ftalocianinas, etc. Novas substâncias vêm sendo desenvolvidas visando obter-se a otimização do processo fotodinâmico dos fotossensibilizadores.

Os fotossensibilizadores porfirínicos são denominados como primeira geração. Dentre eles incluem-se a hematoporfirina (Hp) e seus derivados $(40,52)$. Schwartz e colaboradores (53) demonstraram que o preparado contendo Hp, uma porfirina existente no sangue, era acompanhado por impurezas e que posteriormente às purificações o resíduo era mais retido no tecido tumoral que a própria Hp. Com isto iniciou-se o estudo de derivados de hematoporfirinas $(\mathrm{HpD})$ como fotossensibilizador.

O Photofrin ${ }^{\circledR}$ é obtido a partir da purificação parcial da Hp resultando em uma forma liofilizada concentrada de monômeros e oligômeros. Este foi o primeiro fotossensibilizador comercial e é utilizado até hoje em tratamentos de câncer de pulmão, colo do útero, bexiga e esôfago com TFD $(54,55)$.

Apesar do êxito obtido empregando-se estas substâncias como fotossensibilizadores, elas possuem um tempo de eliminação do organismo relativamente alto, sendo que os pacientes devem evitar a luz solar por até oito semanas. As bandas de absorção da maioria destes compostos estão centradas em comprimentos de ondas inferiores à faixa correspondente à janela terapêutica. Para os compostos que apresentam bandas de absorção nesta faixa, o coeficiente de absortividade molar é baixo, implicando na necessidade de grandes quantidades de fotossensibilizadores para obter o efeito fotodinâmico (43).

$\mathrm{Na}$ busca para suprimir estas desvantagens surgiu uma variedade de fotossensibilizadores chamada de segunda geração. Dentre eles incluem-se as clorinas, baterioclorinas, benzoporfirinas, ftalocianinas, naftalocianinas, purpurinas, hipercina, entre outros $(56,57)$. Em relação à primeira geração, estes compostos apresentam melhorias farmacocinéticas e físico-químicas, acarretando no maior rendimento quântico de formação de oxigênio singleto proveniente da irradiação na janela terapêutica (20). Por exemplo, a $m$-tetrahidroxifenil clorina (Foscan $®$ ), um fotossensibilizador de segunda geração, apresenta uma banda de absorção mais intensa e 
centrada em comprimento de onda maior que o Photofrin ${ }^{\circledR}$. O Foscan ${ }^{\circledR}$ é utilizado para tratamentos de câncer de esôfago, pulmão, laringe e de pele $(50,58,59)$.

Em geral, os fotossensibilizadores de segunda geração apresentam baixa solubilidade em meio aquoso. Para aprimorar esta limitação, sistemas que transportam os fotossensibilizadores até o tecido alvo com seletividade e especificidade (fotossensibilizadores de terceira geração) têm sido empregados (60-62). Idealmente, este sistema de transporte permite que concentrações terapêuticas de fotossensibilizador se acumulem seletivamente no tecido doente enquanto que a captação em tecidos normais seja desprezível (60). Estes sistemas incluem micelas, lipossomos (63), dendrímeros (64), nanopartículas poliméricas, metálicas, cerâmicas (65-67) entre outros.

\subsubsection{Clorinas}

As clorinas são derivadas de um composto natural, a clorofila, cujas funções estão correlacionadas à fotossíntese (68). Similarmente aos derivados porfirínicos, a estrutura molecular destas substâncias é constituída por quatro anéis pirrólicos ligados por pontes de carbono, porém com a saturação de uma ligação dupla na periferia do anel macrocíclico Figura 2 (69). Esta redução do anel pirrólico acarreta na diminuição da conjugação de ligações duplas e da simetria da molécula, conferindo às clorinas características fotofísicas e fotoquímicas favoráveis para o uso como fotossensibilizador (56).

Figura 2- Estrutura molecular genérica das clorinas.

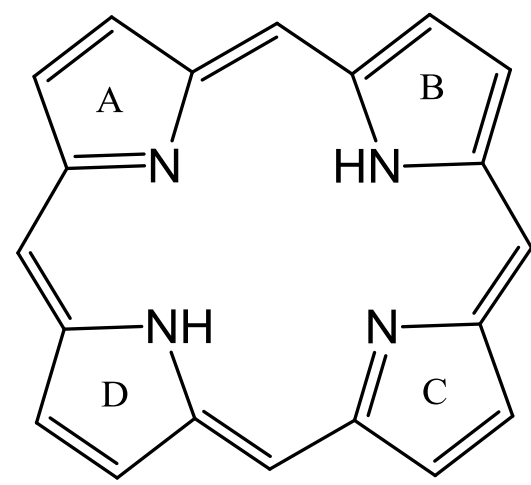

Fonte: Adaptação de Oliveira (2014), p.42 (69).

As clorinas são fotossensibilizadores de segunda geração, os quais têm como principal característica um coeficiente de absortividade molar relativamente intenso na 
região compreendida entre 630-680 $\mathrm{nm}$. Isto permite o tratamento de lesões mais profundas devido à alta penetração da luz na região da janela terapêutica (70). Além disso, são eficientes na geração de espécies reativas de oxigênio e possuem baixa toxicidade (69).

Em função da redução de um dos anéis pirrólicos, as clorinas são termodinamicamente favoráveis a se oxidarem durante o processo. Em geral, como forma de contornar o processo oxidativo emprega-se substituintes volumosos ou anéis exocíclicos ligados ao anel (56).

A literatura descreve três principais métodos para a síntese das clorinas $(56,69)$ : (i) a derivatização de porfirinas- promove uma reação de redução, oxidação ou cicloadiação em compostos porfirínicos (71); (ii) a síntese total- utiliza uma rota de síntese complexa e com várias etapas que permite a inserção de grupos distintos em cada um dos anéis macrocíclicos aumentando a estabilidade foto-oxidativa do composto (72) e (iii) a modificação de produtos naturais- inserção de um grupo funcional em uma substância que ocorre naturalmente, por exemplo, a clorofila a (73).

Assim como a maioria dos fotossensibilizadores de segunda geração, algumas clorinas são altamente lipofílicas. Esta característica propicia a penetração do fotossensibilizador na bicamada fosfolipídica da célula. Em contrapartida, a hidrofobicidade e a baixa solubilidade em meio aquoso constituem empecilhos para o desenvolvimento de fármacos. Além disso, são responsáveis pela agregação destes compostos que, por sua vez, modificam as propriedades fotoquímicas e de biodistribuição do fotossensibilizador.

O processo de autoagregação das clorinas reduz o rendimento quântico de fluorescência, de estado tripleto e de formação de oxigênio singleto, consequentemente diminuindo a potencialidade destes fotossensibilizadores $(74,75)$. Neste âmbito, têm-se desenvolvido novas clorinas no intuito de minimizar esse processo.

Zhang e colaboradores desenvolveram uma nova clorina denominada mesotetra-3-morflinometil-4-metoxifenil (TMMC) que apresentou um alto coeficiente de absortividade molar $\left(\varepsilon_{\mathrm{DMF}}=17,667 \mathrm{~L} \mathrm{~mol}^{-1} \mathrm{~cm}^{-1}\right)$ em $655 \mathrm{~nm}, \Phi_{\Delta}=0,59$, acumulou-se preferencialmente no citoplasma e nas membranas nucleares e foi capaz de inativar as linhagens tumorais de esôfago humano (Eca-109) e nasofaríngico humano (KB) em concentrações relativamente baixas (76).

Outro estudo realizado por de Assis e colaboradores descreveu a síntese total de uma nova clorina contendo vários grupos funcionais ligados aos anéis pirrólicos. A estrutura obtida impediu a formação de agregados do tipo $\mathrm{H}$ devido à distorção da 
planaridade do centro porfirínico e ainda resultou em um composto fotoestável, com alto rendimento quântico de formação de oxigênio singleto e de fluorescência $\left(\Phi_{\Delta}=0,42\right.$ e $\left.\Phi_{\mathrm{F}}=0,34\right)$, implicando na possível aplicação deste composto tanto em TFD como em diagnósticos por fluorescência (77).

Fotossensibilizadores do tipo clorina vem sendo empregados em TFD, principalmente em tratamentos oncológicos de cabeça e pescoço $(22,58)$. A clorina conhecida comercialmente como Visudyne ${ }^{\circledR}$ foi o primeiro fármaco aprovado pela agência americana de controle de alimentos e fármacos para o tratamento de degeneração macular da retina por TFD (78). A clorina m-HTPC comercializada como Foscan ${ }^{\circledR}$ tem sido usada para TFD em tratamentos oncológicos de próstata, mama, pâncreas, gastrointestinal entre outros $(22,59,79)$. Cita-se ainda que estudos de inativação fotodinâmica de células (80) e de microrganismos patogênicos (81) utilizando a clorina e6 e seus derivados têm sido reportados nos últimos anos.

\subsubsection{Hipericinas}

A hipericina, (HY, 4,5,7,4,5 ,7 -hexahidroxi-2,2 - dimetilnaftodiantrona) é um agente fotossensível natural constituinte da planta herbácea do gênero Hipericum perforatum, popularmente conhecida como erva de São João $(57,82)$. Este composto também pode ser obtido sinteticamente utilizando como precursor um derivado de antraquinona denominado 1,3,8-trihidroxi-6-metil-10H-antraceno-9-ona (83).

Durante muitos séculos, plantas do tipo Hipericum foram empregadas na medicina popular para o tratamento de inflamações nos brônquios, infecções do trato geniturinário e como agente cicatrizante no tratamento de feridas, traumas e queimaduras (57). Atualmente, o extrato de Hipericum é amplamente empregado contra depressão suave e moderada (82).

$\mathrm{O}$ recente interesse neste composto é devido ao seu potencial como agente antiviral, antiretroviral, bactericida, antipsoriático e antitumoral; além de apresentar muitas propriedades de um fotossensibilizador ideal: baixa toxicidade, alto rendimento quântico de estado tripleto e formação do oxigênio singleto e ânions superóxidos (82, 84).

A estrutura molecular da HY (Figura 3) é constituída de várias ligações duplas conjugadas que possuem metilas e hidroxilas ligadas a carbonos da chamada região de 
baía e hidroxilas ligadas a carbonos periféricos. Este composto é classificado quimicamente como um derivado de naftodiantrona.

Figura 3- Estrutura molecular da hipericina (HY).<smiles></smiles>

Fonte: Adaptado de Agostinis (2002), p.222 (82).

A HY é solúvel em uma gama de solventes orgânicos polares como dimetilsulfóxido, acetona, acetato de etila e álcoois. Nestes solventes, este composto encontra-se na forma monomérica até uma concentração de aproximadamente $10^{-3} \mathrm{~mol}$ $\mathrm{L}^{-1}$ e possui um rendimento quântico de fluorescência próximo a 0,2 (85). Em meio biológico é igualmente solúvel devido ao complexo formado com macromoléculas (DNA, albumina e outras proteínas do plasma sanguíneo, fragmentos de membranas e outros compostos celulares) (86).

No entanto, na maioria dos solventes apolares e em meio aquoso a HY é insolúvel e hidrofóbica. A formação de cargas líquidas está intimamente relacionada à solubilidade na molécula. Em meio ácido a HY apresenta-se em sua forma neutra, enquanto que em $\mathrm{pH}$ em torno de 7,0 ela existe predominantemente na forma de monoânion. Em ambos os casos a HY é insolúvel. Em soluções alcalinas este composto torna-se parcialmente solúvel devido à formação de diânions em solução (87).

Existem dois mecanismos distintos para o processo de autoagregação da HY em soluções aquosas: (i) agregação do tipo empilhamento (face a face) em que se formam agregados do tipo H e (ii) agregação planar (agregados do tipo J) através de ligações de hidrogênio entre as metilas e as hidroxilas da região de baía de diferentes moléculas (82, 87).

Apesar de sua hidrofobicidade, estudos in vitro tem revelado a versatilidade fotodinâmica da HY. Alguns autores sugerem que ela provavelmente seja o fotossensibilizador mais poderoso encontrado na natureza $(83-85,88,89)$. A conjugação 
deste fotossensibilizador em sistemas carreadores como nanopartículas lipídicas, micelas, dendrímeros e/ou a inserção de grupamentos hidrofílicos otimizam a solubilidade em meio aquoso e a ação fotodinâmica da HY.

Lima e colaboradores demonstraram que a encapsulação da HY em nanopartículas lipídicas sólidas gerou um formulado com solubilidade, fotoestabilidade, rendimento quântico de formação de oxigênio singleto, acumulação intracelular e fototoxicidade melhoradas em relação à HY (66). Outro estudo realizado por Souza e colaboradores observou que a funcionalização de nanotubos peptídicos pela HY aumentou não apenas a geração de espécies reativas de oxigênio como também o tempo de vida de fluorescência, sugerindo a possibilidade de uso deste formulado para TFD e diagnósticos por fluorescência (90).

Estudos envolvendo a combinação de fotossensibilizadores têm sido uma abordagem inovadora no intuito de maximizar a potencialidade fotodinâmica dos compostos empregados em diagnósticos e tratamentos clínicos (91). Gyenge e colaborados observaram que tanto a HY quanto um formulado lipossomal da clorina mTHPC, comercialmente conhecido como Foslipos $®$ e ainda a mistura equivalente entre eles foram capazes de gerar oxigênio singleto, acumular-se no interior das células e inativar as linhagens celulares tumorais UMB-SCC 745 e UMB-SCC 969 (92, 93).

\subsection{Avaliação da eficiência dos fotossensibilizadores}

\subsubsection{Formação de oxigênio singleto em ambientes micelares}

Diferentes métodos vêm sendo empregados para detecção e quantificação de oxigênio singleto, sendo eles os métodos direto e estacionário. No método direto, acompanha-se a emissão de fosforescência em $1270 \mathrm{~nm}$ em função do tempo (94). Este método é altamente eficiente, porém exige um sistema sofisticado que dificulta a difusão desta técnica. No método estacionário, quantifica-se a oxidação de substratos específicos que atuam como sequestradores químicos de oxigênio singleto. Os sequestradores usuais são o 1,3-difenilisobenzofurano (DPBF) (12), o p-nitroso dimetilanilina (RNO) (13) e o ácido úrico (AU) (7).

A baixa solubilidade de alguns sequestradores e fotossensibilizadores em meio aquoso pode ser uma desvantagem para o uso do método estacionário. Empregando-se microambientes hidrofóbicos constituídos por micelas, carreadores ou nanopartículas pode-se minimizar os efeitos da agregação nestas condições. 
Os microambientes micelares (MA) são formados por moléculas de surfactantes anfifílicas constituídas de uma parte apolar (hidrofóbica) e uma parte polar (hidrofílica) (95). Os surfactantes são classificados como iônicos possuindo cargas elétricas (aniônicos, catiônicos ou zwiteriônicos) e não iônicos que são neutros. Sua característica comum é a formação espontânea, acima de uma determinada concentração, de estruturas auto-organizadas denominadas micelas (96).

Os MA são amplamente utilizados na Química, cujas principais finalidades são modificar o meio reacional permitindo a solubilização de espécies de baixa solubilidade ou otimizar o meio para influenciar a velocidade reacional, a posição e o tempo que as reações químicas necessitam para atingirem o equilíbrio e em alguns casos até mesmo a estereoquímica da reação (95).

Outra propriedade importante das micelas é apresentarem uma estrutura muito similar às membranas biológicas (95). As membranas biológicas são constituídas por uma dupla camada de fosfolipídios organizados analogamente ás micelas: cadeia apolar hidrocarbônica apontando para dentro da membrana e a parte polar das moléculas formam a superfície da membrana.

As membranas biológicas são sistemas funcionais onde ocorrem fenômenos de penetração, transporte, diferenciação morfológica, entre outros (97). Devido à sua complexidade e a semelhança existente com ambientes micelares, estudos mostram que o uso destes sistemas biométricos é satisfatório para uma triagem inicial da interação de fotossensibilizadores com as membranas celulares (98-100).

\subsubsection{Lipofilicidade}

A biodistribuição de um fotossensibilizador pode ser estimada pela determinação in vitro do coeficiente de partição $(\log \mathrm{P})$. Esta análise mimetiza o equilíbrio de partição do composto entre o meio aquoso e o meio hidrofóbico das membranas celulares ou proteínas (50). Para o meio aquoso emprega-se água ou soluções tampão e para o ambiente hidrofóbico é empregado o 1-octanol.

A partição de um soluto entre duas fases líquidas parcialmente miscíveis é um fenômeno governado pela Lei de Distribuição. Se o soluto, neste caso especificamente o fotossensibilizador, distribui-se entre a fase aquosa e a fase orgânica, o equilíbrio resultante pode ser escrito como: 


$$
F S_{(a q)} \rightleftarrows F S_{(o r g)}
$$

Equação 1

onde $(a q)$ e $($ org) referem-se à fase aquosa e orgânica, respectivamente.

Considerando-se a temperatura constante, a razão das atividades de fotossensibilizador nas duas fases no equilíbrio, idealmente, é constante e independente da quantidade total de fotossensibilizador. Esta constante de equilíbrio é conhecida como constante de partição $(\mathrm{P})$. Geralmente o valor de $\mathrm{P}$ aproxima-se da razão entre a solubilidade do soluto em cada um dos solventes (101). O coeficiente de partição P é comumente descrito em sua forma logarítmica na base $10(\log \mathrm{P})$ e permite comparar a solubilidade dos FS, ou seja, o caráter lipofílico ou hidrofílico dos FS.

\subsubsection{Agregação}

Agregados moleculares são aglomerados macroscópicos de moléculas com tamanhos intermediários entre cristais e monômeros. Em geral, o processo de autoagregação dos fotossensibilizadores em solução é devido a fortes interações intermoleculares do tipo Van der Walls entre o sistema conjugado dos componentes com orbitais $\pi$ estendidos (102).

A espectroscopia de absorção e a espectrometria de emissão de fluorescência são os métodos mais sensíveis para o estudo quantitativo das propriedades de agregação de fotossensibilizadores em solução. Isso se deve ao fato de que, normalmente, a relação monômero-dímero existente em equilíbrio pode ser detectada nas faixas de concentrações empregadas nestes métodos. Tais metodologias permitem diferenciar monômeros e dímeros através de mudanças espectrais.

Geralmente, os agregados moleculares são classificados com base nos deslocamentos espectrais da máxima absorção e/ou fluorescência em relação ao posicionamento das bandas espectrais do monômero (39). Os agregados do tipo H são caracterizados por deslocamento hipsocrômico, enquanto que agregados do tipo J normalmente acarretam em deslocamento batocrômico (Figura 4) (103).

Em agregados do tipo $\mathrm{H}$, dois ou mais monômeros são sobrepostos entre si, sendo que a direção do empilhamento é aproximadamente perpendicular ao plano da molécula (face a face). Em agregados do tipo J, os monômeros são deslocados entre si paralelamente ao plano da molécula. 
Figura 4- Representação gráfica da formação de agregados do tipo H e J para moléculas com orbitais $\pi$ estendidos e seus respectivos espectros de absorção.

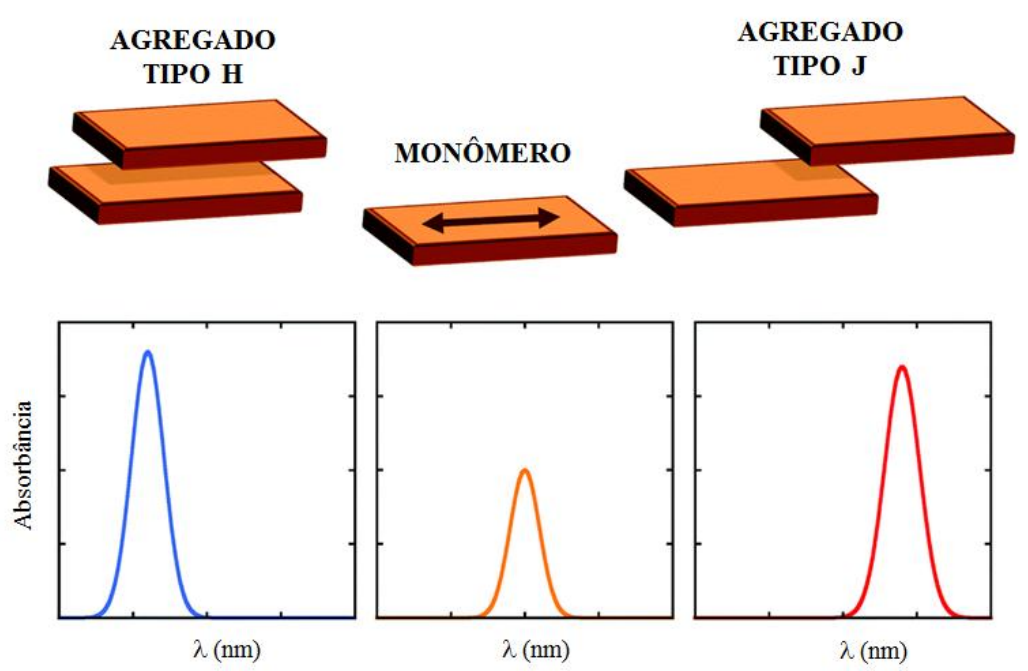

Fonte: Adaptado de Pescitelli (2014), p 5217 (102).

Estes agregados ocorrem em consequência de vários fatores: estéricos e eletrostáticos, hidrofobicidade, interações iônicas, força iônica, $\mathrm{pH}$, presença de microambientes de membranas e proteínas (104). A concentração necessária de FS para resultar no efeito citotóxico é outro fator a ser considerado. O aumento da concentração destes compostos favorece a formação de agregados e pode causar efeitos colaterais quando administrados sistemicamente.

A formação de agregados minimiza a eficiência quântica do processo fotodinâmico, uma vez que podem ocorrer decaimentos não radiativos por conversão interna, acarretando na redução do tempo de vida do estado tripleto e dificultando a transferência de energia do fotossensibilizador para o ${ }^{1} \mathrm{O}_{2}(74,75)$.

\subsubsection{Decomposições químicas e fotoinduzidas}

Outro fator que pode afetar a concentração do fotossensibilizador ativo é a sua decomposição. Uma decomposição limitada pode ocorrer mesmo sob o abrigo da luz em ambiente refrigerado, ou seja, em condições de armazenamento. Esta decomposição pode ser agravada pela irradiação cujo fenômeno é denominado como fotobranqueamento de corantes.

O fotobranqueamento é um processo fotoquímico identificado pelo decréscimo na intensidade de absorção ou emissão das moléculas do fluoróforo quando submetidas 
à exposição de luz $(11,105)$. O fotobranqueamento puro é caracterizado por mudanças químicas intensas que resultam no desaparecimento total da absorção ou fluorescência do composto, enquanto que a fotomodificação é a diminuição que pode ser acompanhado do deslocamento espectral de absorção ou de fluorescência $(19,106)$.

Para alguns fotossensibilizadores estas fotomodificações tornam-se uma vantagem, pois podem gerar fotoprodutos que exibem características mais favoráveis para o uso em TFD do que o composto de origem. Correa e colaboradores (107) demostraram que a irradiação utilizando luz vermelha no Photoditazine, um derivado de clorina e6, gera fotoprodutos cujas bandas de absorção são deslocadas para comprimentos de onda maiores do espectro. A maior citotoxicidade do derivado nos ensaios com culturas celulares cancerígenas foi atribuída aos fotoprodutos.

\subsubsection{Propriedades fotofísicas}

O rendimento quântico de fluorescência $\left(\Phi_{\mathrm{F}}\right)$ e o tempo de vida de fluorescência $\left(\tau_{\mathrm{F}}\right)$ são outras características fotofísicas importantes para os fluoróforos, principalmente relacionados às aplicações em diagnósticos por fluorescência (108).

Para aplicações em fototerapias, uma das características almejadas para um fotossensibilizador é que o composto apresente um alto rendimento quântico de formação de estado tripleto. Entretanto para diagnósticos é mais relevante que o fotossensibilizador exiba um alto $\Phi_{\mathrm{F}}$.

Idealmente, o tratamento de tumores deve ser precedido na demarcação da região comprometida, seguida de sua completa eliminação. O monitoramento da fluorescência promove o aumento da precisão no processo de erradicação de célulasalvo por TFD (109). Portanto, fotossensibilizadores que apresentem características intermediárias de $\Phi_{\mathrm{F}}$ e $\tau_{\mathrm{F}}$ podem ser úteis em ambas as aplicações.

\subsubsection{Acumulação intracelular}

Os mecanismos envolvidos na acumulação preferencial dos fotossensibilizador nas células tumorais ainda não estão totalmente elucidados, no entanto, a hipótese mais difundida na literatura relaciona a seletividade do fotossensibilizador com a lipofilicidade dos tecidos (110). Observa-se que FS lipofílicos são melhores incorporados pelas células tumorais (50). A carga elétrica e a estrutura molecular 
também são descritos como primordiais no processo de acumulação intracelular de fotossensibilizadores (4).

Estudos envolvendo o efeito da carga elétrica na acumulação de fotossensibilizadores tem revelado que cargas negativas são desfavoráveis para a penetração em membranas celulares. Todavia, a difusão do composto através da membrana plasmática pode ser facilitada se o composto apresentar até duas cargas negativas e alta lipofilicidade (4).

Além disto, fatores como a especificidade celular, características extracelulares do tumor e diferença de $\mathrm{pH}$ entre os tecidos saudáveis e tumorais podem contribuir para esta seletividade (111).

\subsubsection{Ensaios citotóxicos em culturas celulares e o planejamento fatorial}

Estudos comparativos utilizando-se ensaios citotóxicos em culturas celulares é o passo inicial para o protocolo de desenvolvimento de fármacos, pois pode-se mimetizar as interações que ocorrem in vivo (10). Dentre estes ensaios são possíveis a comparação da eficiência de inibição da proliferação pela contagem de células viáveis ou elucidando-se o mecanismo das alterações bioquímicas.

A cultura de células se refere a culturas derivadas de células dispersas retiradas do tecido original, de uma cultura primária ou de uma linhagem celular já estabelecida em cultura por desagregação enzimática, mecânica ou química (97). Geralmente, células imortalizadas são utilizadas em trabalhos com cultura celular, uma vez que podem ser usadas indefinidamente (112).

A viabilidade celular pode ser quantificada indiretamente pelo monitoramento da integridade da mitocôndria empregando-se o corante 3-(4,5-dimetiltiazol-2yl)-2,5difenil brometo de tetrazolina (MTT). As desidrogenases mitocondriais das células viáveis reduzem o MTT (corante amarelo) a um produto conhecido como Formazan (violeta) que pode ser mensurado espectroscopicamente em $570 \mathrm{~nm}$ (113-115).

Através dos ensaios citotóxicos em culturas celulares é possível obter a concentração inibitória média $\left(\mathrm{IC}_{50}\right)$. Esse parâmetro é um indicativo da quantidade necessária de fotossensibilizador para inibir, em 50\%, o crescimento celular (116). O $\mathrm{IC}_{50}$ pode ser interpretado como a quantificação da eficiência de um fotossensibilizador em inviabilizar o crescimento celular. Em experimentos de fototoxicidade, o valor $\mathrm{IC}_{50}$, é inversamente proporcional à fotoatividade do fotossensibilizador. 
De maneira geral, o processo de morte celular observado nos ensaios citotóxicos é dependente de vários fatores como, por exemplo, do tipo de linhagem celular e fotossensibilizador empregado bem como da taxa de incorporação deste composto no interior da célula e da dose de luz empregada em cada ensaio (17).

Em sua maioria, estes ensaios são realizados de forma univariada, isto é, varia-se um dos fatores e mantêm-se os demais constantes. No entanto, utilizando-se experimentos multivariados é possível correlacionar os diferentes fatores e evidenciar as interações relevantes por meio da quimiometria (18).

O uso do planejamento experimental permite avaliar simultaneamente o efeito de um grande número de variáveis, a partir de um número reduzido de ensaios experimentais, quando comparados aos processos univariados $(18,117)$. Dentre os métodos de planejamento experimental disponíveis na literatura, o planejamento fatorial é o mais indicado quando se deseja estudar os efeitos de duas ou mais variáveis de influência, considerando-se que todas as combinações possíveis dos níveis de cada variável serão investigadas (18). 


\section{OBJETIVOS}

\subsection{Objetivo Geral}

O objetivo geral deste trabalho foi caracterizar as propriedades físico-químicas e fotodinâmicas de fotossensibilizadores por técnicas espectroscópicas, investigar os processos envolvidos na interação destes compostos com sistemas biofísicos modelos e determinar a eficiência fotodinâmica destes compostos em cultura celulares. Os fotossensibilizadores estudados foram uma Clorina (CHL) e uma Hipericina (HY) e seus derivados com solubilidade em sistema aquoso melhorada pela inserção de grupamentos hidrofílicos, denominado Clorina Trizma (CHL-T) e Hipericina Glucamina (HY-G).

\subsection{Objetivos Específicos}

(i) Analisar a influência do $\mathrm{pH}$, força iônica e formação de agregados moleculares para os fotossensibilizadores;

(ii) Investigar a interação destes compostos com os surfactantes iônicos;

(iii) Avaliar a estabilidade química destas substâncias frente à irradiação;

(iv) Quantificar a formação de oxigênio singleto pela fotoativação do fotossensibilizador;

(v) Determinar o rendimento quântico e o tempo de vida de fluorescência dos compostos;

(vi) Avaliar o grau de lipofilicidade dos fotossensibilizadores;

(vii) Quantificar a concentração de fotossensibilizador acumulado no interior das células;

(viii) Avaliar a influência da concentração do fotossensibilizador, tempo de incubação e dose de luz na toxicidade dos fotossensibilizadores em culturas celulares utilizando planejamento fatorial;

(ix) Determinar a concentração inibitória média $\left(\mathrm{IC}_{50}\right)$ na presença e ausência de luz em células tumorais e células normais;

(x) Propor um modelo matemático para a determinação do $\mathrm{IC}_{50}$ empregando planejamento fatorial. 


\section{MATERIAIS E MÉTODOS}

\subsection{Reagentes e equipamentos}

Neste trabalho utilizou-se uma clorina (CHL) e seu derivado obtido pela inserção do grupo hidrofílico trizma, denominando-o Clorina Trizma (CHL-T) (Figura 5). As duas substâncias foram sintetizadas no Laboratório de Química Bio-orgânica, do Departamento de Química da Universidade Federal de São Carlos, coordenado pelo professor Kleber T. de Oliveira.

Figura 5- Estrutura molecular da (a) Clorina (CHL) e (b) Clorina Trizma (CHL-T).

(a)

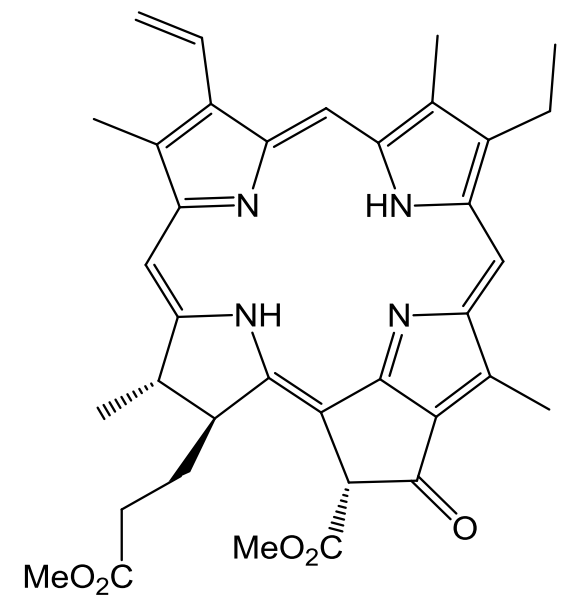

(b)

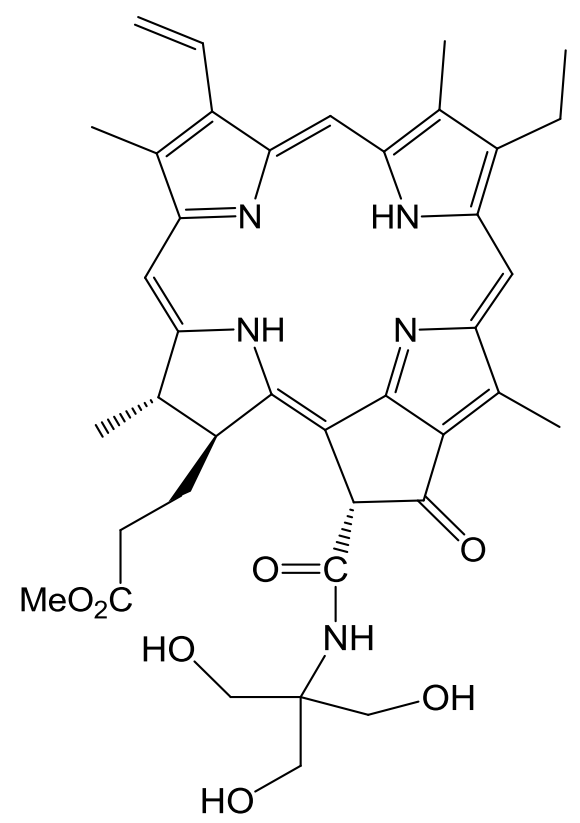

Além das clorinas, utilizou-se a hipericina (HY) e a hipericina-glucamina (HYG) obtida pela inserção de um grupo hidrofílico N-metil-glucamina (Figura 6). Estes compostos foram sintetizados no Centro de Ciências Naturais e Humanas da Universidade Federal do ABC coordenado pelo professor Anderson O. Ribeiro. 
Figura 6- Estrutura molecular da (a) Hipericina (HY) e (b) Hipericina Glucamina (HYG).

(a)<smiles></smiles>

(b)<smiles></smiles>

Todos os compostos foram gentilmente cedidos para o desenvolvimento do presente trabalho.

Para cada um dos fotossensibilizadores preparou-se uma solução estoque de concentração $1 \mathrm{mg} \mathrm{mL}^{-1}$ em dimetilsulfóxido (DMSO), esterilizada por filtração em membrana com poro de $0,22 \mu \mathrm{m}$ e mantida ao abrigo da luz a $4^{\circ} \mathrm{C}$. O dimetilsulfóxido tem sido empregado há décadas por sua miscibilidade em água e baixa toxicidade até aproximadamente $3 \% \mathrm{v} / \mathrm{v}$. Possui a capacidade de solubilizar muitos fármacos insolúveis em meio aquoso, facilitando a distribuição das drogas nos microambientes de sistemas químicos ou biológicos ou mesmo auxiliando nas suas permeações através das membranas biológicas; e ainda quando é desejável, um solvente com acidez negligenciável.

Como modelos simplificados de membranas foram utilizados os surfactantes iônicos dodecil sulfato de sódio- SDS (Sigma), brometo de hexadeciltrimetilamônioCTAB (Riedel de Haën) e o surfactante não iônico monolaurato de polioxietilenosorbitan- Tween 20 (Sigma), cujas estruturas e propriedades relevantes para o presente trabalho estão apresentadas na Tabela 1. O surfactante Tween 20 foi empregado ainda em determinados experimentos, cuja função específica foi solucionar a baixa solubilidade dos fotossensibilizadores em solução aquosa em pH 7,0.

Os espectros eletrônicos na região ultravioleta e visível foram obtidos em um espectrofotômetro HITACHI U-2800, utilizando-se cubeta de quartzo, com duas faces polidas e caminho ótico de $1,00 \mathrm{~cm}$. As medidas de fluorescência foram realizadas em espectrofluorímetro HITACHI F-4500 utilizando-se cubeta de quartzo, com quatro faces polidas e caminhos óticos de $1,00 \mathrm{~cm}$. 
Tabela 1- Propriedades dos surfactantes utilizados neste estudo.

\begin{tabular}{ccccc} 
Nome & $\begin{array}{c}\text { Característica } \\
\text { do surfactante }\end{array}$ & $\begin{array}{c}\mathrm{CMC} \\
\left(\mathrm{mol} \mathrm{L}^{-1}\right)\end{array}$ \\
\hline CDS & Aniônico & $8,0 \times 10^{-3}$ \\
CaAB & Catiônico & $9,2 \times 10^{-4}$ & \\
Tween & Não iônico & $5,9 \times 10^{-5}$ &
\end{tabular}

onde CMC é a concentração micelar crítica.

Os experimentos para a determinação do tempo de vida de fluorescência foram realizados no laboratório de Fotoquímica do Instituto de Química de São Carlos (IQSC). Utilizou-se um fluorímetro Easy Life $\mathrm{V}^{\mathrm{TM}}$ equipado com um LED pulsado (1,5 ns) centrado em $370 \mathrm{~nm}$ para a excitação dos fotossensibilizadores e um filtro passa-banda centrado em $420 \mathrm{~nm}$.

As determinações de células viáveis para os ensaios citotóxicos foram realizadas em um leitor de placas modelo Benchmark (BIO-RAD) determinando-se as absorbâncias com filtro com máximo de transmissão em $570 \mathrm{~nm}$. Foram realizados experimentos paralelos de contagens de células viáveis em câmara de Newbauer.

Todas as análises físico-químicas foram realizadas em temperatura ambiente $\left(20^{\circ} \mathrm{C}\right)$ e os solventes DMSO (Synth) e etanol (Synth) de grau analítico foram empregados sem purificações adicionais. As soluções aquosas foram obtidas empregando-se água deionizada com padrão Milli-Q (Millipore Corporation, Billerica, MA, EUA).

As fontes de luz utilizadas neste trabalho são protótipos desenvolvidos pelo Laboratório de Apoio Técnico do Centro de Pesquisas em Ótica e Fotônica (CEPOF) do IFSC-USP. O conjunto de LED em forma de matriz denominada Biotable é adequado para irradiação de culturas celulares em placas e frascos planos. As fontes empregadas apresentam a emissão centrada em 590 nm (amarelo) e em 660 nm (vermelho), com irradiâncias selecionáveis. Ambas as fontes exibem o perfil de gaussiana com largura de $\pm 10 \mathrm{~nm}$. A escolha do comprimento de onda da emissão do LED foi realizada de acordo 
com a estrutura molecular e consequentemente, do espectro de absorção dos fotossensibilizadores.

\subsection{Metodologia}

4.2.1 Determinação do rendimento quântico de fluorescência ( $\Phi F)$ e do tempo de vida de fluorescência $(\tau \mathrm{F})$

Para a determinação do $\Phi_{\mathrm{F}}$ dos fotossensibilizadores, utilizou-se o método que relaciona o $\Phi_{\mathrm{F}}$ de um composto padrão com o da amostra em estudo (Equação 2) (118). Como padrão utilizou-se a rodamina B solubilizada em etanol $\left(\Phi_{\mathrm{F}}=0,65\right)(119)$. Preparou-se soluções dos fotossensibilizadores e de rodamina B em etanol e em DMSO. Os valores das absorbâncias das soluções no comprimento de onda de excitação ( $\lambda_{\text {ex }}=$ $510 \mathrm{~nm}$ ) foram monitorados para assegurar a obediência da lei de Beer-Lambert bem como para minimizar o efeito de filtro interno (118).

$$
\Phi_{F}=\frac{F_{a} \times A_{p} \times \eta_{a}^{2}}{F_{p} \times A_{a} \times \eta_{p}^{2}} \Phi_{F p}
$$

onde: $F$ é a integral da área sob a curva de emissão de fluorescência, $A$ é a absorbância no comprimento de onda de excitação e $\eta$ é o índice de refração dos solventes usados. Os índices $p$ e $a$ identificam o padrão e a amostra problema, respectivamente.

Para a determinação do tempo de vida de fluorescência $\left(\tau_{\mathrm{F}}\right)$ utilizou-se a técnica estroboscópica. Preparou-se soluções de aproximadamente $1 \times 10^{-5} \mathrm{~mol} \mathrm{~L}^{-1}$ dos FS em DMSO. As curvas de resposta do equipamento foram obtidas através da média da análise de quatro experimentos de decaimento de fluorescência que foram ajustados com cinética monoexponencial utilizando-se como referência uma suspensão espalhadora de sílica coloidal (Ludox) com concentração adequada para obter-se uma intensidade de sinal semelhante ao das soluções de FS. Para cada análise o número de canais foi 600 e o tempo de integração foi de 4 segundos. 
4.2.2 Determinação dos coeficientes de partição dos fotossensibilizadores (log P)

Com o intuito de se determinar a hidrofilicidade dos compostos determinou-se o logaritmo da constante de partição $\left(\begin{array}{lll}\log & \mathrm{P}\end{array}\right)$ de soluções $1,43 \times 10^{-5}$ mol $\mathrm{L}^{-1}$ de fotossensibilizadores solubilizados em 1-octanol em relação à fase aquosa (tampão fosfato de sódio $2,0 \times 10^{-2} \mathrm{~mol} \mathrm{~L}^{-1}, \mathrm{pH} 7,0$ ). A suspensão foi agitada vigorosamente por $3 \mathrm{~h}$ protegida da luz para promover a partição do fotossensibilizador entre a fase orgânica e aquosa. A mistura foi centrifugada por 10 minutos a $1000 \mathrm{rpm}$ para a separação das duas fases. Todas as determinações envolveram sistemas compostos por uma fase aquosa e 1-octanol utilizado como fase orgânica previamente saturadas e a temperatura a $20{ }^{\circ} \mathrm{C}$.

A espectroscopia UV-Vis foi utilizada para monitorar as absorbâncias dos fotossensibilizadores na fase orgânica em $667 \mathrm{~nm}$ para CHL e CHL-T e em $590 \mathrm{~nm}$ para HY e HY-G antes e após a partição. O $\log \mathrm{P}$ foi calculado de acordo com uma adaptação do método proposto inicialmente por Pooler e Valenzeno (120): ao invés de se medir a absorbância da fase aquosa, o monitoramento da concentração foi feita comparando-se as absorbâncias da fase orgânica, uma vez que a solubilidade dos fotossensibilizadores estudados é limitada na fase aquosa (Equação 3 ).

$$
\log P=\log \frac{\left(A_{\lambda d}\right)}{\left(A_{\lambda_{0}}-A_{\lambda d}\right)}
$$

onde $\log \mathrm{P}=\log$ aritmo do coeficiente de partição; $A_{\lambda_{0}}=$ absorção da solução antes da partição e $A_{\lambda_{d}}=$ absorção da solução após a partição, ambas medidas no comprimento de onda $\lambda$.

\subsubsection{Formação de agregados moleculares}

Visando-se analisar a susceptibilidade dos fotossensibilizadores em formar agregados, foram preparadas soluções de CHL, CHL-T, HY e HY-G variando-se as concentrações de $1,00 \times 10^{-6}$ a $1,00 \times 10^{-5} \mathrm{~mol} \mathrm{~L}^{-1}$ em tampão fosfato de sódio $2,0 \times 10^{-2}$ mol L ${ }^{-1}$ em pH 7,0. Foram coletados os espectros de absorção UV-Vis de $250 \mathrm{~nm}$ a 800 $\mathrm{nm}$. 
Foram preparadas ainda soluções dos fotossensibilizadores $1,00 \times 10^{-7} \mathrm{~mol} \mathrm{~L}^{-1} \mathrm{em}$ DSMO variando-se a porcentagem de água em solução entre 10 e $90 \%$ para obtenção dos espectros de fluorescência (CHL e CHL-T $\lambda_{\text {ex }}=610 \mathrm{~nm}$ e HY e HY-G $\lambda_{\text {ex }}=545 \mathrm{~nm}$ ).

\subsubsection{Influência do $\mathrm{pH}$ e da força iônica no meio reacional}

Os estudos espectroscópicos dos fotossensibilizadores em função do $\mathrm{pH}$ foram realizados em solução tampão fosfato de sódio $2,0 \times 10^{-2} \mathrm{~mol} \mathrm{~L}^{-1}\left(\mathrm{pK}_{1} 2,12, \mathrm{pK}_{2} 7,21 \mathrm{e}\right.$ $\mathrm{pK}_{3}$ 12,67). As concentrações de fotossensibilizador empregadas foram na ordem de $10^{-6} \mathrm{molL}^{-1}$. O pH foi variado de 0,5 a 13,5 utilizando-se alíquotas de soluções estoques de $\mathrm{HCl}$ e $\mathrm{NaOH}$ em várias concentrações, e tomando-se medidas espectroscópicas a cada variação de $\sim 0,5$ unidade de $\mathrm{pH}$. Para a análise da influência da força iônica no meio reacional, foram utilizadas soluções dos fotossensibilizadores na ordem de $10^{-6}$ mol L ${ }^{-1}$ solubilizados em água e variando-se a concentração de $\mathrm{NaCl}$ de 0 até $8,0 \times 10^{-1}$ mol L ${ }^{-1}$.

\subsubsection{Interação com surfactantes}

Neste estudo utilizou-se os surfactantes iônicos SDS e CTAB e o não iônico Tween 20. Preparou-se soluções de CHL e CHL-T $2,0 \times 10^{-6} \mathrm{~mol} \mathrm{~L}^{-1}$ e HY e HY-G $5,0 \times 10^{-6} \mathrm{~mol} \mathrm{~L}^{-1}$ solubilizadas em diferentes concentrações dos surfactantes em tampão fosfato de sódio $2,0 \times 10^{-2} \mathrm{~mol} \mathrm{~L}^{-1}$ e $\mathrm{pH} 7,0$. As concentrações de surfactantes empregadas variaram de 0 até pelo menos duas vezes a concentração micelar crítica (cmc) do respectivo surfactante (Tabela 1).

\subsubsection{Fotobranqueamento dos fotossensibilizadores}

Para se analisar a fotoestabilidade dos fotossensibilizadores foram empregadas soluções $1,5 \times 10^{-6} \mathrm{~mol} \mathrm{~L}^{-1}$ quando solubilizadas em DMSO e $3,0 \times 10^{-6} \mathrm{~mol} \mathrm{~L}^{-1} \mathrm{em}$ tampão fosfato de sódio $2,0 \times 10^{-2} \mathrm{~mol} \mathrm{~L}^{-1}, \mathrm{pH} 7,0$. As soluções foram irradiadas ininterruptamente por até 1 hora sob agitação para manter constante a reposição de oxigênio. Para as clorinas empregou-se LED com emissão em $660 \pm 10 \mathrm{~nm}$ a uma irradiância de $26,7 \mathrm{~mW} \mathrm{~cm}^{-2}$. As soluções de HY e HY-G foram obtidas nas mesmas 


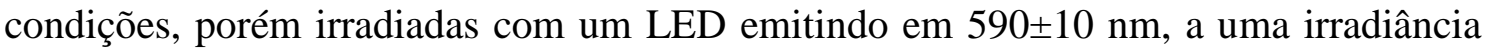
de $15,8 \mathrm{~mW} \mathrm{~cm}^{-2}$. Periodicamente foram separadas alíquotas das respectivas soluções para a obtenção dos espectros de absorção.

As medidas de fluorescência foram empregadas apenas para as soluções de fotossensibilizador em DMSO $\left(\lambda_{\mathrm{ex}}=610 \mathrm{~nm}\right.$ para as clorinas e $545 \mathrm{~nm}$ para as hipericinas), haja vista, que a emissão de fluorescência para os fotossensibilizadores em meio aquoso em pH 7,0 é extremamente baixa.

4.2.7 Estimativa do rendimento quântico de geração de oxigênio singleto pela oxidação do ácido úrico

Neste estudo, empregou-se uma adaptação do método proposto por Fischer e colaboradores (7). A modificação introduzida foi o emprego de 0,001\% de Tween 20 a fim de se minimizar o efeito da baixa solubilidade dos fotossensibilizadores estudados em meio aquoso em $\mathrm{pH}$ 7,0.

Foi preparada uma solução de ácido úrico $1,20 \times 10^{-4} \mathrm{~mol} \mathrm{~L}^{-1}$ em tampão fosfato de sódio $2,0 \times 10^{-2} \mathrm{~mol} \mathrm{~L}^{-1}$, $\mathrm{pH} 7,0$ contendo $0,001 \%$ de Tween 20 . Cada experimento era iniciado após a adição de diferentes concentrações dos fotossensibilizadores $\left(1 \times 10^{-8}\right.$ a $1 \times 10^{-6} \mathrm{~mol} \mathrm{~L}^{-1}$ ) à esta solução. As misturas foram submetidas à irradiação, sob agitação constante. Para as soluções contendo CHL e CHL-T foi empregado o LED vermelho $\left(660 \pm 10 \mathrm{~nm}, \mathrm{I}=27,6 \mathrm{~mW} \mathrm{~cm}^{-2}\right)$ e aquelas contendo HY e HY-G empregou-se o LED amarelo $\left(590 \pm 10 \mathrm{~nm}, \mathrm{I}=15,8 \mathrm{~mW} \mathrm{~cm}^{-2}\right)$.

As absorbâncias dessas soluções foram medidas em $291 \mathrm{~nm}$ ao término das irradiações durante 0, 300, 600, 900 e 1200 s. Considerando o decaimento da intensidade de absorção do ácido úrico neste comprimento de onda, decorrente da reação de oxidação da molécula de ácido úrico pelo oxigênio singleto, determinou-se os valores de atividade fotodinâmica em função da concentração, utilizando-se a Equação 4:

$$
A F=\frac{\Delta A b s_{A U} \times 10^{5}}{I \times \Delta t \times A b s_{(\lambda)}}
$$

Equação 4

onde $A F$ é a atividade fotodinâmica $\left(\mathrm{m}^{2} \mathrm{~W}^{-1} \mathrm{~s}^{-1}=\mathrm{m}^{2} \mathrm{~J}^{-1}\right) ; \Delta A b s_{A U}$ é a variação da intensidade da absorção do ácido úrico em $291 \mathrm{~nm}$, antes e após a irradiação; $I$ é a irradiância da luz $\left(\mathrm{W} \mathrm{m}^{-2}\right) ; \Delta t$ é o intervalo de tempo de irradiação $(\mathrm{s}) ; A b s_{(\lambda)}$ é a 
absorbância do fotossensibilizador na solução (Fotossensibilizador+AU) no comprimento de onda da irradiação do LED.

4.2.8 Estimativa do rendimento quântico de geração de oxigênio singleto pela oxidação do RNO

A solução de p-nitrosanilina (RNO) $5,00 \times 10^{-5} \mathrm{~mol} \mathrm{~L}^{-1}$ e L-histidina $5,00 \times 10^{-5}$ mol $\mathrm{L}^{-1}$ foi preparada em tampão fosfato de sódio $2,0 \times 10^{-2}$ mol L $\mathrm{L}^{-1}$, pH 7,0 contendo $0,001 \%$ de Tween 20 para auxiliar a solubilização dos fotossensibilizadores. O procedimento fotoquímico era iniciado após a adição à esta solução diferentes quantidades dos fotossensibilizadores resultando em concentrações de $1 \times 10^{-8}$ a $1 \times 10^{-6} \mathrm{~mol} \mathrm{~L}{ }^{-1}$. As condições para a excitação dos fotossensibilizadores foram as mesmas empregadas nos ensaios com o AU.

A decomposição do RNO foi acompanhada pela medida da absorbância em 441 $\mathrm{nm}$ a cada 30s durante um período de tempo de 300s. A formação de oxigênio singleto é proporcional à queda da absorbância em função do tempo de irradiação. Portanto, podese quantificar a capacidade do fotossensibilizador em produzir oxigênio singleto comparando-se o coeficiente angular da reta que expressa esta fotodecomposição em função da concentração do fotossensibilizador.

4.2.9 Estimativa do rendimento quântico de geração de oxigênio singleto pela oxidação do DPBF

A oxidação do 1,3-Difenilisobenzofurano (DPBF) foi acompanhada pela absorbância em $411 \mathrm{~nm}$ de uma solução etanólica de $10 \mathrm{~mL}$ de DPBF $\left(1,4 \times 10^{-4} \mathrm{~mol} \mathrm{~L}^{-1}\right)$ e fotossensibilizador com absorção média de 0,0035 para as clorinas e 0,026 para as hipericinas no $\lambda$ máximo de emissão do LED empregado. Estas soluções foram irradiadas nas mesmas condições descritas para o AU. Foram retiradas alíquotas desta solução em intervalos de tempo de 5s para o monitoramento da absorbância.

A quantificação dos rendimentos quânticos da geração de oxigênio singleto foi realizada relativo à ftalocianina de zinco solubilizada em DMSO $\left(\Phi_{\Delta} \mathrm{ZnPC}=0,72\right)(121)$ empregando-se a Equação 5: 


$$
\Phi_{\Delta}=\frac{k_{a} \times\left(1-10^{A b s_{p}}\right) \times \eta_{p}^{2}}{k_{p} \times\left(1-10^{A b s_{a}}\right) \times \eta_{a}^{2}} \Phi_{\Delta_{p}}
$$

onde $\mathrm{k}$ é a constante de velocidade de fotodecomposição do DPBF, $\eta$ é o índice de refração dos solventes usados, Abs é a absorbância do fotossensibilizador no comprimento de onda da irradiação e os índices $p$ e $a$ identificam o padrão e a amostra problema, respectivamente.

\subsubsection{Experimentos biológicos}

\subsubsection{Ação fotodinâmica sobre células de mamíferos}

Nos ensaios citotóxicos foram utilizadas as linhagens de células epiteliais de rim de macaco verde africano VERO (ATCC CCL-81) e de carcinoma epidermóide de laringe humana, HEp- 2 (ATCC CCL-23) e endotelial de cordão umbilical humano, HUVEC (ATCC CRL-1730) (122). Devido às suas características biológicas, essas linhagens foram cultivadas aderidas a um substrato sólido, neste caso, garrafas de polipropileno com fundo chato, em meio de cultura Dulbecco modificado por Iscovis, acrescido de $10 \%$ de soro fetal bovino (SFB) e antibióticos penicilina 10000 U.I. $\mathrm{mL}^{-1}$ e estreptomicina $10 \mathrm{mg} \mathrm{mL}^{-1}$. As células foram mantidas em estufa a $37{ }^{\circ} \mathrm{C}, 95 \%$ de ar e $5 \%$ de $\mathrm{CO}_{2}$ gasoso. Todas as manipulações celulares foram realizadas em ambiente previamente esterilizado com radiação ultravioleta, numa capela de fluxo laminar, com materiais estéreis $(97,123)$.

O subcultivo celular foi feito a cada três dias removendo-se o meio de cultura seguido de adição de PBS para retirar os resíduos de meio de cultura. Na sequência, adicionou-se a enzima tripsina com $0,03 \%$ de etilenodiaminotetracético (EDTA), um agente quelante que se liga ao $\mathrm{Ca}^{2+}$ responsável pela adesão entre as células e o substrato. O meio de cultura foi adicionado logo após a desagregação das células para inativar a tripsina pela ação do soro fetal bovino. As células foram transferidas para um tubo cônico e centrifugadas a $1000 \mathrm{rpm}$ durante $1 \mathrm{~min}$, descartou-se o sobrenadante e ressuspendeu-se as células em meio de cultura (97). Posteriormente a homogeneização em meio de cultura, retirou-se uma alíquota para contagem e distribuiu-se as células 
conforme a concentração celular desejada, em frascos de cultura ou recipientes apropriados para os ensaios celulares.

A viabilidade celular foi determinada utilizando-se o método da contagem em câmara de Newbauer empregando-se o teste de discriminação das células mortas das viáveis pela incorporação seletiva de corante, denominando-se, portanto teste de exclusão do corante. $\mathrm{O}$ azul de tripano, ou do inglês- trypan blue, é um corante seletivo para as células cuja integridade da membrana foi danificada, ou seja, ele é incorporado somente em células mortas. Portanto, retirou-se uma alíquota de $100 \mu \mathrm{L}$ da suspensão celular, adicionou-se $500 \mu \mathrm{L}$ de PBS e $400 \mu \mathrm{L}$ de solução $0,4 \%$ de azul de tripano. Esta suspensão celular foi inserida parcialmente na câmara de Newbauer e as células de todos os quadrantes foram contadas. A média aritmética do número de células foi multiplicada por $10^{4}$ e pelo fator de diluição 10 obtendo-se desta forma o número de células por $\mathrm{mL}$ de suspensão (124).

Considerando-se a determinação do número de células mortas (que apresentam uma coloração violeta devido à incorporação do corante) e vivas (incolores devido a ausência de corante incorporado), calculou-se a viabilidade celular em porcentagem (\%) (Equação 6).

Viabilidade celular $(\%)=\frac{\text { número de células não coradas } \times 100}{\text { número total células }} \quad$ Equação 6

Todos os ensaios biológicos foram realizados com a viabilidade celular superior a $85 \%$.

\subsubsection{Acumulação intracelular de fotossensibilizadores}

Cinco mililitros de uma suspensão contendo de $1 \times 10^{5}$ células $\mathrm{mL}^{-1}$ foram introduzidos em placas de Petri de $60 \mathrm{~mm}$ de diâmetro contendo meio de cultura Dulbecco modificado por Iscovis, acrescido de $10 \%$ de soro fetal bovino (SFB) e antibióticos penicilina 10000 U.I. $\mathrm{mL}^{-1}$ e estreptomicina $10 \mathrm{mg} \mathrm{mL}^{-1}$. Após $24 \mathrm{~h}$ de condicionamento das células, isto é, a adesão do filme de células, substituiu-se por meio de cultura contendo $1,5 \times 10^{-6} \mathrm{~mol} \mathrm{~L}^{-1}$ de fotossensibilizador. As células foram mantidas em contato com os fotossensibilizadores nos tempos de 0,$5 ; 1 ; 2$ e $4 \mathrm{~h}$. 
Retirou-se o meio contendo o fotossensibilizador, lavou-se a monocamada celular com PBS, adicionou-se $0,5 \mathrm{~mL}$ de tripsina/EDTA para a remoção das células, transferindo-se a suspensão celular para um tubo cônico. Reservou-se o precipitado de células resultante da centrifugação por $1 \mathrm{~min}$ a $1000 \mathrm{rpm}$. As células foram lavadas com $1 \mathrm{~mL}$ de PBS, descartando-se novamente o sobrenadante.

A seguir, homogeneizou-se o sedimento em $500 \mu \mathrm{L}$ de PBS, reservando-se 100 $\mu \mathrm{L}$ da suspensão para a determinação de proteína pelo método de Lowry (125) e empregando-se como padrão a albumina de soro bovino (BSA). A concentração proteica foi estimada empregando-se uma curva padrão obtida com soluções de BSA com concentrações entre 0,02 a $0,2 \mathrm{mg} \mathrm{mL}^{-1}$.

O restante da suspensão celular foi centrifugado descartando-se o sobrenadante. Ao sedimento celular adicionou-se $1 \mathrm{~mL}$ de etanol para se extrair o fotossensibilizador. Após leve agitação aguardou-se 1 h e novamente centrifugou-se por $10 \mathrm{~min}$ a $1000 \mathrm{rpm}$, em seguida comparou-se a leitura de fluorescência com os valores de uma curva padrão para se determinar as concentrações dos fotossensibilizadores. As concentrações de cada fotossensibilizador foram normalizadas pela concentração de proteína na amostra que é diretamente proporcional ao número de células.

\subsubsection{Ensaios citotóxicos}

\subsubsection{Ensaios na presença de planejamento fatorial}

Para a avaliação do potencial fotodinâmico da CHL, CHL-T, HY e HY-G em uma possível aplicação terapêutica, foram realizados experimentos de citotoxicidade dos fotossensibilizadores utilizando-se um planejamento fatorial completo $2^{3}$, ou seja, dois níveis em cada um dos três fatores (18). A atribuição dos fatores foi baseada na concentração de fotossensibilizador, tempo de incubação do fotossensibilizador na célula e dose de luz enquanto que a resposta foi referente ao índice de sobrevivência celular. Em relação aos níveis, para cada fator têm-se o inferior (-) e o superior (+) (Tabela 2).

Com exceção da concentração do fotossensibilizador, os outros dois fatores foram os mesmos para todos os compostos e para as duas linhagens celulares estudadas. No caso do fator tempo de incubação do fotossensibilizador na célula o nível inferior corresponde à $1 \mathrm{~h}$ e o nível superior à $2 \mathrm{~h}$ de incubação. Para o fator dose de luz os 
valores foram 6 e $12 \mathrm{~J} \mathrm{~cm}^{-2}$ para o nível inferior e superior, respectivamente. A irradiação foi realizada utilizando LED vermelho $660 \pm 10 \mathrm{~nm}, \mathrm{I}=26,7 \mathrm{~mW} \mathrm{~cm}{ }^{-2}$ para CHL e CHL-T e LED amarelo 590 $\pm 10 \mathrm{~nm}, \mathrm{I}=15,8 \mathrm{~mW} \mathrm{~cm}^{-2}$ para HY e HY-G.

Tabela 2- Matriz de planejamento aplicado nos experimentos de citotoxicidade dos fotossensibilizadores para o planejamento fatorial $2^{3}$.

\begin{tabular}{c|c|c|c}
\hline Experimento & [Fotossensibilizador] & $\begin{array}{c}\text { Tempo de } \\
\text { incubação }\end{array}$ & Dose de Luz \\
\hline 1 & - & - & - \\
2 & + & - & - \\
3 & - & + & - \\
4 & + & + & - \\
5 & - & - & + \\
6 & + & - & + \\
7 & - & + & + \\
8 & + & + & + \\
\hline
\end{tabular}

onde os fatores são concentração de fotossensibilizador (CHL, CHL-T, HY e HY-G), tempo de incubação do fotossensibilizador na célula e dose de luz.

As concentrações empregadas no planejamento experimental para os fotossensibilizadores foram determinadas baseadas em estudos anteriores do grupo de Fotossensibilizadores $(66,126)$ e encontram-se listadas na Tabela 3.

Tabela 3- Concentrações molares dos fotossensibilizadores empregados no planejamento experimental.

\begin{tabular}{c|c|c|c|c}
\hline Nível & CHL $\left(\mathrm{mol} \mathrm{L}^{-1}\right)$ & CHL-T $\left(\mathrm{mol} \mathrm{L}^{-1}\right)$ & $\mathrm{HY}\left(\mathrm{mol} \mathrm{L}^{-1}\right)$ & $\mathrm{HY}-\mathrm{G}\left(\mathrm{mol} \mathrm{L}^{-1}\right)$ \\
\hline- & $6 \times 10^{-8}$ & $2 \times 10^{-8}$ & $2 \times 10^{-8}$ & $2 \times 10^{-8}$ \\
+ & $1,2 \times 10^{-7}$ & $4 \times 10^{-8}$ & $4 \times 10^{-8}$ & $4 \times 10^{-8}$ \\
\hline
\end{tabular}

Para a aplicação do planejamento experimental, $1 \times 10^{5}$ células $\mathrm{mL}^{-1}$ em meio de cultura foram distribuídas em placas de cultura de 96 poços e incubadas a $37^{\circ} \mathrm{C}$ e $5 \%$ de $\mathrm{CO}_{2}$ gasoso. Após $24 \mathrm{~h}$, removeu-se o meio de cultura e empregou-se PBS para retirar qualquer resíduo de meio de cultura. Em seguida, as células foram incubadas em 
meio de cultura contendo a concentração de fotossensibilizador desejada. Executou-se o planejamento fatorial proposto, isto é, variando-se as concentrações do fotossensibilizador e o tempo de incubação nos dois níveis supracitados. Após o período de incubação, retirou-se o meio de cultura contendo o fotossensibilizador, procedendose a lavagem com PBS a fim de eliminar possíveis resíduos de fotossensibilizadores livres em solução. Adicionou-se meio de cultura sem fotossensibilizadores irradiando-se então com o devido LED em doses previamente determinadas no planejamento experimental. Após a irradiação, as células foram mantidas em estufa de cultura por 48 h para se determinar as células sobreviventes após submetidos ao tratamento fotodinâmico (127). Decorrido este tempo o meio de cultura foi substituído por uma solução $1 \mathrm{mg} \mathrm{mL}^{-1}$ de 3-4,5-dimetiltiazol-2-il-2,5-difenil brometo de tetrazolio (MTT) solubilizado em meio de cultura. O método de contagem celular baseia-se na redução do MTT a um derivado denominado Formazan. Esta redução é feita pelas desidrogenases mitocondriais ativas somente nas células vivas. Após $3 \mathrm{~h}$ de incubação o meio com MTT foi retirado e $50 \mu \mathrm{L}$ de etanol foi adicionado para completa solubilização dos cristais de Formazan. Adicionou-se $150 \mu \mathrm{L}$ de uma mistura de PBS e álcool isopropílico $50 \%$ v/v para se medir a absorbância em $570 \mathrm{~nm}(113,114)$.

\subsubsection{Ensaios na ausência de planejamento fatorial}

O procedimento experimental para a execução dos ensaios na ausência do planejamento fatorial foi semelhante à metodologia previamente descrita para os ensaios utilizando esta ferramenta estatística. Contudo, as células foram incubadas com diferentes faixas de concentração para cada fotossensibilizador por um período de $2 \mathrm{~h}$.

Por meio destes ensaios, foi possível a obtenção do valor da concentração inibitória média $\left(\mathrm{IC}_{50}\right)$, que representa a concentração da substância capaz de matar $50 \%$ da população de células, utilizando-se o programa CalcuSyn (128).

\subsection{Análise dos dados}

\subsubsection{Cálculo da média e desvio padrão}


Os valores experimentais foram expressos como média \pm desvio padrão. A média foi calculada empregando-se a Equação 7 e o desvio padrão a Equação 8, respectivamente $(18,129)$ :

$$
\begin{gathered}
\overline{x l}=\frac{\sum_{i=1}^{n} \overline{x l}}{n} \\
s=\sqrt{\frac{\sum_{i=1}^{n}(X i-X i)^{2}}{n-1}}
\end{gathered}
$$

Equação 7

Equação 8

onde: $\bar{x}$ é a média amostral, i é a i=ésima observação, $n$ é o número total de observações e $s$ é o desvio padrão amostral.

\subsubsection{Análise dos espectros}

Os espectros de UV-Vis e de fluorescência foram analisados utilizando-se o algoritmo "Convex Constraint Algorithm" (CCA) desenvolvido por Perczel e coloboradores (130). O CCA é um método geral de deconvolução para um conjunto completo de funções que são obtidas pela combinação linear de outras funções. Este programa requer a definição do número de funções base $\left(\mathrm{f}_{\mathrm{i}}\right)$. A definição é baseada em dois princípios. No primeiro caso cada função base corresponde ao espectro de uma das substâncias presentes na solução. Quando há dúvida quanto ao número de espécies químicas, a aplicação do algoritmo baseia-se em sequências de tentativas escolhendo-se a combinação que apresente o menor valor de chi-quadrado.

\subsubsection{Testes estatísticos de validação experimental}

O número de réplicas para cada experimentos foi 3. Aplicou-se o teste $Q$ de Dixon para identificação e rejeição de valores anômalos. A análise estatística dos valores experimentais foi feita utilizando-se o teste $\mathrm{t}$ de Student para mostrar a significância da diferença entre pares de médias analisados (129). O nível de significância é de $95 \%$ para todas as análises estatísticas. Todos os tratamentos estatísticos e quimiométricos foram realizados no programa Excel ${ }^{\circledR} 2010$. 


\section{RESULTADOS E DISCUSSÕES}

Como previamente descrito no item 2.2 os fotossensibilizadores além de apresentarem bandas com elevado coeficiente de absorção na região da janela terapêutica, devem conter diversas propriedades para que sejam úteis em diagnósticos e na TFD. Por isso, é de suma importância o estudo das propriedades físico-químicas e fotodinâmicas da Clorina (CHL), Clorina Trizma (CHL-T), Hipericina (HY) e Hipericina Glucamina (HY-G). Dentre essas propriedades destacam-se a lipofilicidade, agregação, interação com sistemas biofísicos modelo, estabilidade, eficiência na produção de oxigênio singleto e toxicidade dos compostos.

\subsection{Caracterização espectroscópica dos fotossensibilizadores}

As soluções em DMSO da CHL e do seu derivado CHL-T apresentaram os espectros de absorção característicos de compostos tetrapirrólicos reduzidos: uma banda intensa assimétrica denominada de Soret com máximos de absorção em 411, 396 e 366 $\mathrm{nm}$ e quatro bandas $\mathrm{Q}$ simétricas de menor intensidade, denominadas $\mathrm{Q}_{\mathrm{y}}(1,0), \mathrm{Q}_{\mathrm{y}}(0,0)$, $\mathrm{Q}_{\mathrm{x}}(1,0)$ e $\mathrm{Q}_{\mathrm{x}}(0,0)$ com máximos de absorção em 506, 538, 607 e 667 nm, respectivamente (Figura 7).

De uma maneira geral, os espectros de absorção de clorinas e porfirinas são semelhantes. No entanto, para as clorinas a banda de Soret é assimétrica, possuindo um comprimento de onda máximo e três desdobramentos denominados ombros. Isso ocorre devido à contribuição dos três esteroisômeros existentes devido à redução da ligação dupla de um dos anéis pirrólico (anel $\mathrm{D}$ da Figura 2) (131). Em relação à banda $\mathrm{Q}_{\mathrm{x}}(0,0)$ de clorinas, apresentam-se com maior intensidade de absorção devido à diminuição da simetria molecular causada por esta redução. Além disso, esta banda apresenta-se deslocada para comprimento de ondas maiores, uma vez que a energia necessária para a excitação de um elétron do macrociclo porfirínico é proporcional ao número de elétrons $\pi$ conjugados existentes na molécula.

O número de elétrons $\pi$ é de 20 para as clorinas e 22 para as porfirinas. Portanto, a energia necessária para a excitação de elétrons em clorinas é menor do que para as porfirinas e, consequentemente a absorção ocorrerá em um maior comprimento de onda (132). 
Figura 7: Espectros de absorção (a) CHL e (b) CHL-T em DMSO e tampão fosfato de sódio $2,0 \times 10^{-2} \mathrm{~mol} \mathrm{~L}^{-1}, \mathrm{pH} \mathrm{7,0}$.

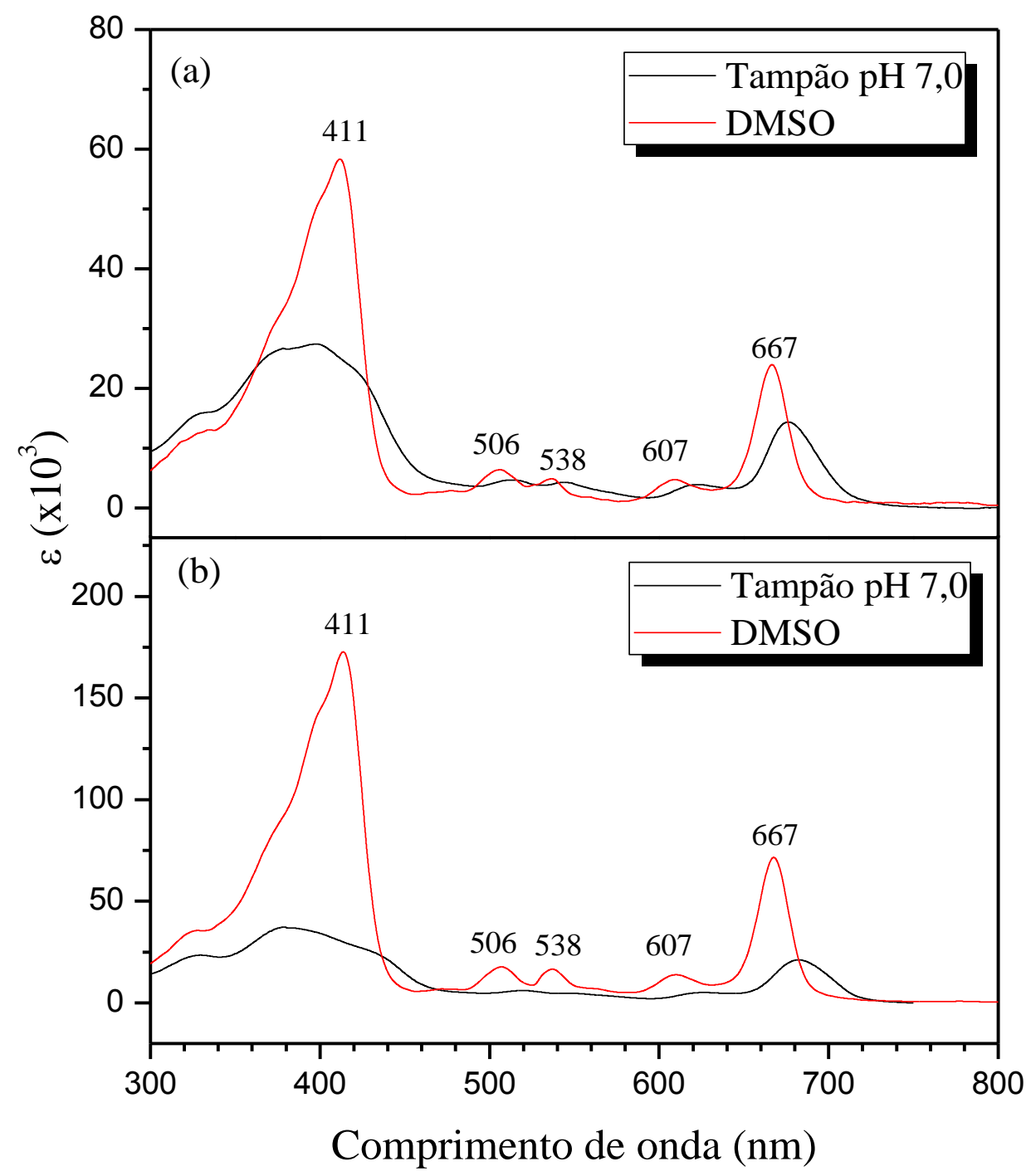

As transições eletrônicas de maior energia para estes compostos são provenientes do tipo $\pi \rightarrow \pi^{*}$ e caracterizam-se na região da banda de Soret. As transições do tipo $n \rightarrow \pi^{*}$ são as de menor energia e situam-se na região da banda Q ( $\varepsilon_{667}=22900 \mathrm{e}$ $72900 \mathrm{~L} \mathrm{~mol}^{-1} \mathrm{~cm}^{-1}$ para CHL e CHL-T, respectivamente).

Para ambas as clorinas estudadas, observou-se que o coeficiente de absortividade molar $(\varepsilon)$ da banda de Soret foi 2,4 vezes maior que da banda $Q_{x}(0,0)$. Contudo, a aplicabilidade desta banda de absorção em TFD é limitada pelo baixo grau de penetração da luz desta faixa de comprimento de onda em tecidos biológicos.

Outra limitação para o uso de clorinas como fotossensibilizador é a sua solubilidade em meio aquoso. A hidrofobicidade e a estrutura planar do orbital $\pi$ estendido de algumas clorinas podem favorecer a agregação em meio aquoso de 
sistemas biológicos. A tendência de agregação da CHL e CHL-T em meio aquoso (tampão fosfato de sódio $2,0 \times 10^{-2} \mathrm{~mol} \mathrm{~L}^{-1}, \mathrm{pH} 7,0$ ) foi evidenciada pela análise dos espectros de absorção. As bandas $\mathrm{Q}_{\mathrm{x}}(0,0)$ presentes no espectro tornam-se alargadas em relação às características espectrais em DMSO (os valores de largura a meia altura são 39 e 23 e 36 e 23) para CHL e CHL-T em meio aquoso e DMSO, respectivamente). Ocorre também um ligeiro deslocamento para comprimentos de onda maiores para as bandas Q e menores para a banda de Soret (Figura 7).

A hipericina e muitos de seus derivados também apresentam baixa solubilidade em meio aquoso $(66,87)$. A polaridade do solvente afeta diretamente características espectrais como posicionamento e largura de bandas não apenas deste composto, mas também de seus derivados $(87,133,134)$. A Figura 8 apresenta os espectros de absorção para a HY e HY-G em DMSO e tampão fosfato de sódio 2,0×10 $\mathrm{mol} \mathrm{L}^{-1}$.

Figura 8: Espectros de absorção da (a) HY e (b) HY-G em DMSO e tampão fosfato de sódio $2,0 \times 10^{-2} \mathrm{~mol} \mathrm{~L}^{-1}$, pH 7,0.

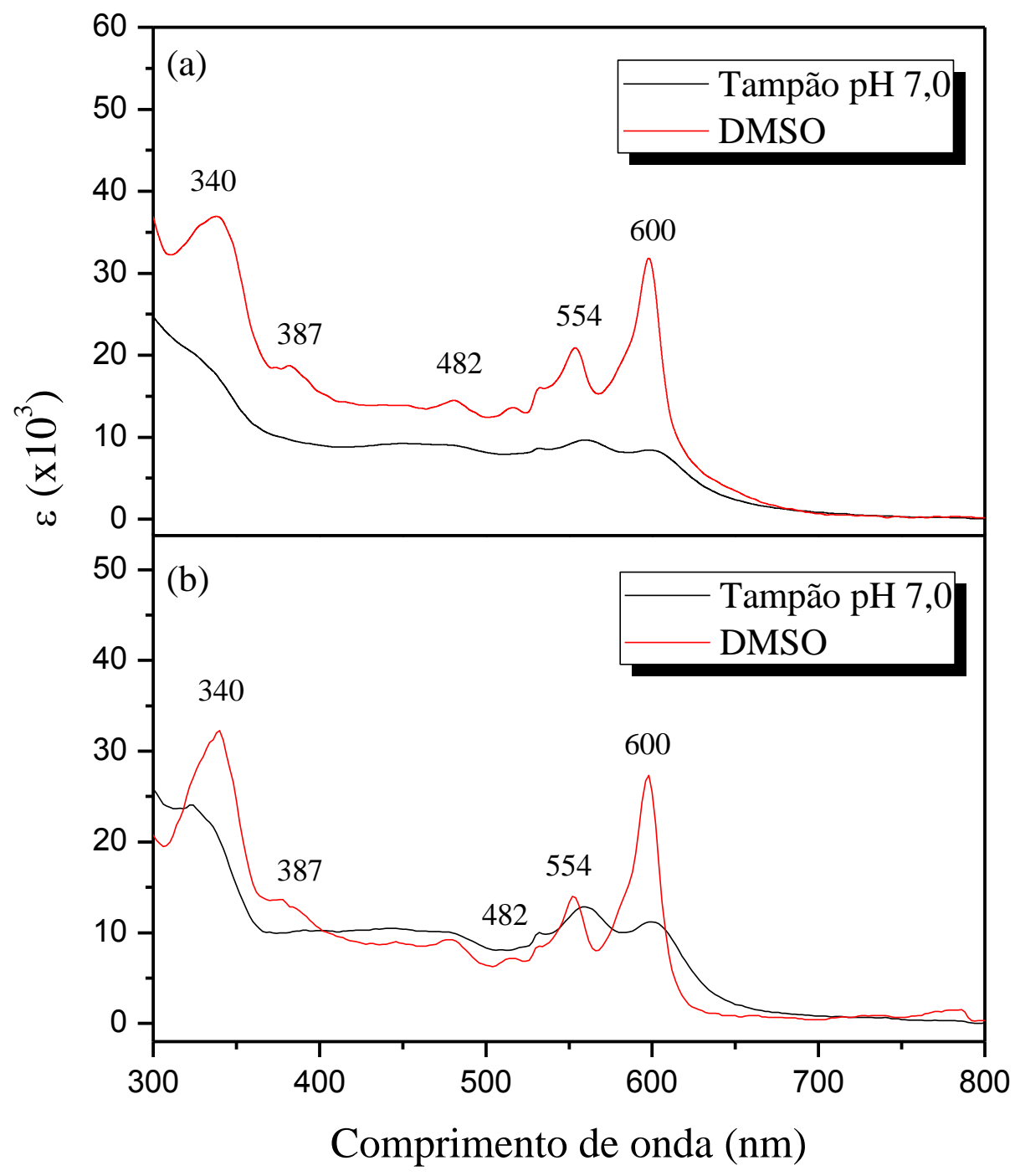


Observou-se que a HY e HY-G apresentaram duas principais bandas de absorção centradas em 556 e 598 nm, atribuídas à forma agregada e monomérica, respectivamente. Semelhante ao que acontece com CHL e CHL-T, as diferenças na intensidade e largura das bandas foram causadas pela baixa solubilidade destes compostos em meio aquoso. Isso foi evidenciado pela diminuição da banda de absorção atribuída à forma agregada e o aumento concomitante da banda do monômero em DMSO. Estas discrepâncias nos espectros de absorção causadas pela agregação da HY já foram anteriormente descritas para este composto solubilizado em etanol (135), lipossomas (133), ligados a proteínas (134) entre outros.

Os espectros de absorção e emissão de fluorescência são modificados devido à presença de agregados em solução e de outros fatores que causam deslocamentos das bandas e desvios na lei de Beer-Lambert (39, 136). Dentre estes fatores, o solvente empregado pode promover a competição entre processos não radiativos e emissão de fluorescência, acarretando em sua supressão. Para os fotossensibilizadores empregados neste estudo, o meio aquoso neutro favoreceu a supressão da emissão de fluorescência que será melhor descrita no item 5.9. Desta forma, foi possível obter-se os espectros de emissão de fluorescência apenas em DMSO ilustrados na Figura 9.

Observou-se que CHL e CHL-T (Figura 9(a)) quando excitadas na região da banda Q (610nm) exibiram uma banda na região compreendida entre 665-695 nm proveniente de uma única espécie fluorescente. No caso da HY e HY-G (Figura 9(b)), quando excitadas em $545 \mathrm{~nm}$ observou-se duas faixas de emissão distintas compreendidas entre 590-630 nm e 640-670 nm provenientes de duas espécies fluorescentes (monômero e dímero). Os espectros de emissão de fluorescência corroboram com a hipótese previamente inferida pela espectroscopia de absorção de similaridade dos grupos cromóforos, ainda que inseridos grupamentos hidrofílicos nas moléculas. 
Figura 9: Espectros de emissão de fluorescência dos fotossensibilizadores em DMSO para (a) CHL e CHL-T e (b) HY e HY-G. Concentração dos fotossensibilizadores $1,7 \times 10^{-7} \mathrm{~mol} \mathrm{~L}^{-1}$.

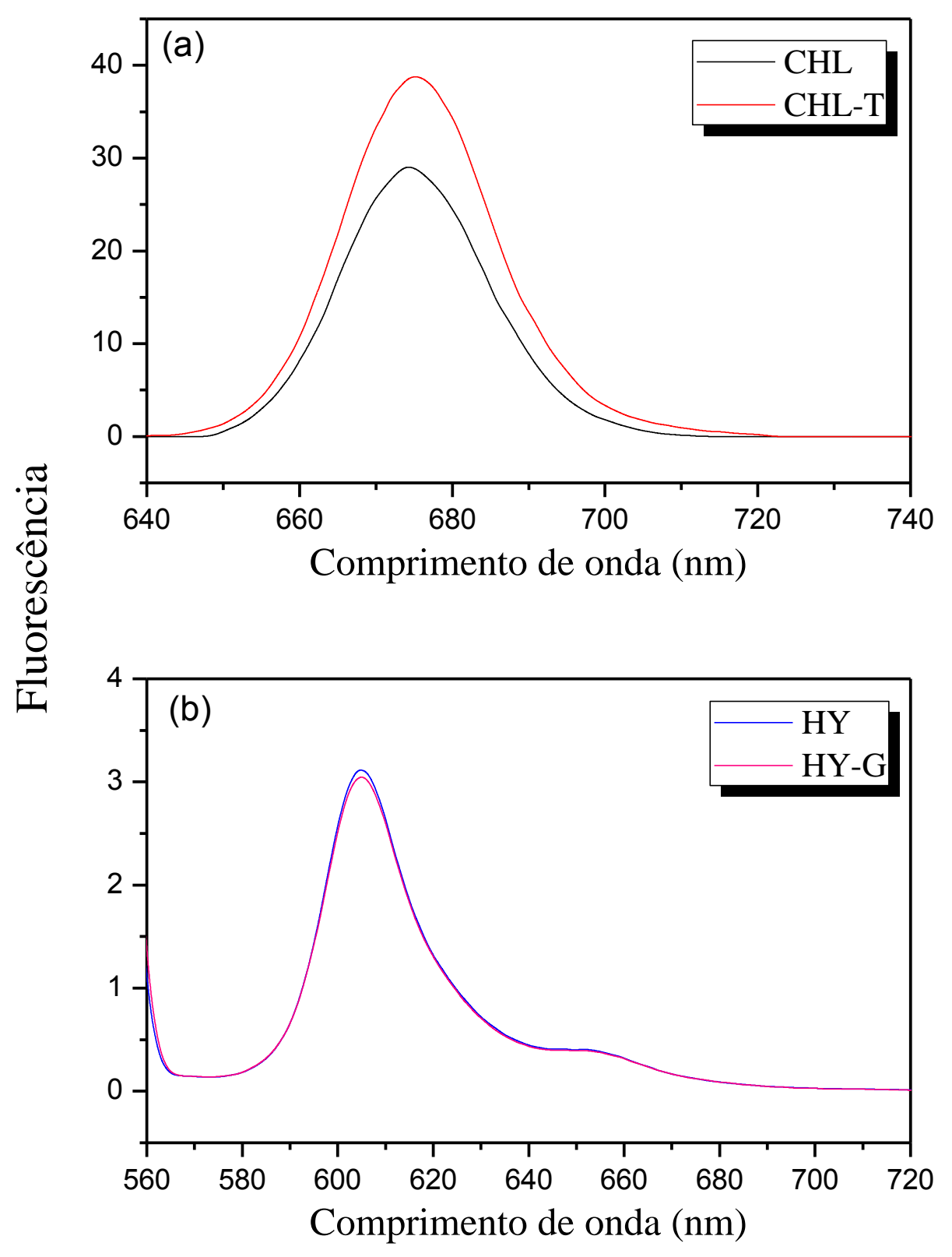

O rendimento quântico de fluorescência $\left(\Phi_{\mathrm{F}}\right)$ é comumente determinado relativamente a uma substância padrão (118). Os valores de $\Phi_{\mathrm{F}}$ para os fotossensibilizadores foram determinados utilizando-se a Equação 2 e empregando-se como padrão de fluorescência a rodamina B (119) (Tabela 4). 
Tabela 4- Parâmetros fotofísicos dos fotossensibilizadores.

\begin{tabular}{cccccc}
\hline Fotossensibilizador & $\Phi_{\mathrm{F}}$ & $\tau_{\mathrm{F}}(\mathrm{ns})$ & $\mathrm{a}_{1}$ & $\chi^{2}$ & D.W. \\
& $0,0218 \pm 0,0022$ & $1,55 \pm 0,01$ & $0,91 \pm 0,02$ & 0,93 & 1,68 \\
CHL & $0,0133 \pm 0,0004$ & $1,80 \pm 0,04$ & $0,82 \pm 0,09$ & 0,92 & 1,73 \\
CHL-T & $0,1083 \pm 0,0056$ & $4,96 \pm 0.02$ & $1,10 \pm 0.01$ & 1.18 & 2,00 \\
HY & $0,0614 \pm 0,0045$ & $1,52 \pm 0,02$ & $0,93 \pm 0,01$ & 1,07 & 1,93 \\
\hline onde: & $\Phi_{\mathrm{F}}$ é o rendimento quântico de fluorescência, $\tau_{\mathrm{F}}$ é o tempo de vida de \\
fluorescência, a & é o fator pré-exponencial, $\chi^{2}$ é a distribuição estatística de resíduos e \\
D.W. é fator de Durbin-Watson.
\end{tabular}

Apesar de a HY apresentar um valor de $\Phi_{\mathrm{F}}$ cerca de 1,7 vezes maior que a $H Y-$ $\mathrm{G}$, considerando-se a análise estatística não há diferenças significativas no $\Phi_{\mathrm{F}}$ entre estes dois fotossensibilizadores (teste t não pareado utilizando-se teste F com $\sigma$ que não difere significativamente). Em análise semelhante, as clorinas exibiram $\Phi_{\mathrm{F}}$ diferentes estatisticamente (teste $t$ não pareado utilizando-se teste $\mathrm{F}$ com $\sigma$ que difere significativamente).

Comparando-se os compostos empregados neste estudo, observou-se que a CHL apresentou um $\Phi_{\mathrm{F}}$ cerca de 3 vezes e a CHL-T cerca de 5 vezes menor que as hipericinas. Todavia, todos os fotossensibilizadores apresentaram baixos valores de $\Phi_{\mathrm{F}}$, quando comparados a substâncias utilizadas como fluoróforos em diagnósticos clínicos. Sugere-se que apenas uma pequena parte da população do estado singleto excitado dos compostos deste estudo resultou na emissão de fluorescência.

As curvas de decaimento para a obtenção do $\tau_{\mathrm{F}}$ foram ajustadas no modelo monoexponencial. A acurácia do modelo foi definida por três fatores: (i) $\chi^{2}$ - que deve apresentar valores reduzidos, (ii) DW- com valores próximos a 2 e (iii) fator préexponencial que deve ser próximo a unidade.

Os valores de $\tau_{\mathrm{F}}$ da CHL e HY-G não apresentaram diferenças significativas (teste $\mathrm{t}$ não pareado utilizando-se teste $\mathrm{F}$ com $\sigma$ que não difere significativamente), contudo foram ligeiramente inferiores à CHL-T, que por sua vez foi aproximadamente 3 
vezes menor que a HY. Isto era esperado, considerando que o $\tau_{\mathrm{F}}$ é diretamente proporcional ao $\Phi_{\mathrm{F}}(137)$.

Portanto, estes resultados mostraram um indício de que a maioria da população do estado singleto excitado sofreu cruzamento intersistema, resultando no estado tripleto de mais baixa energia, favorecendo assim, a conversão do oxigênio molecular (tripleto) existente nos tecidos ao estado singleto.

\subsection{Estudos da estabilidade dos fotossensibilizadores em função do tempo de armazenamento}

Uma das características desejáveis para o fotossensibilizador é a estabilidade em função do tempo de armazenamento (42). As soluções de trabalho foram preparadas por meio da diluição de uma solução estoque armazenada ao abrigo da luz a $4^{\circ} \mathrm{C}$. Para acompanhar a estabilidade ao longo da realização dos experimentos, os espectros de absorção foram monitorados periodicamente (Figura 10).

Figura 10: Espectro de absorção em DMSO no período de 180 dias para (a) CHL, (b) CHL-T e (c) HY e (d) HY-G.
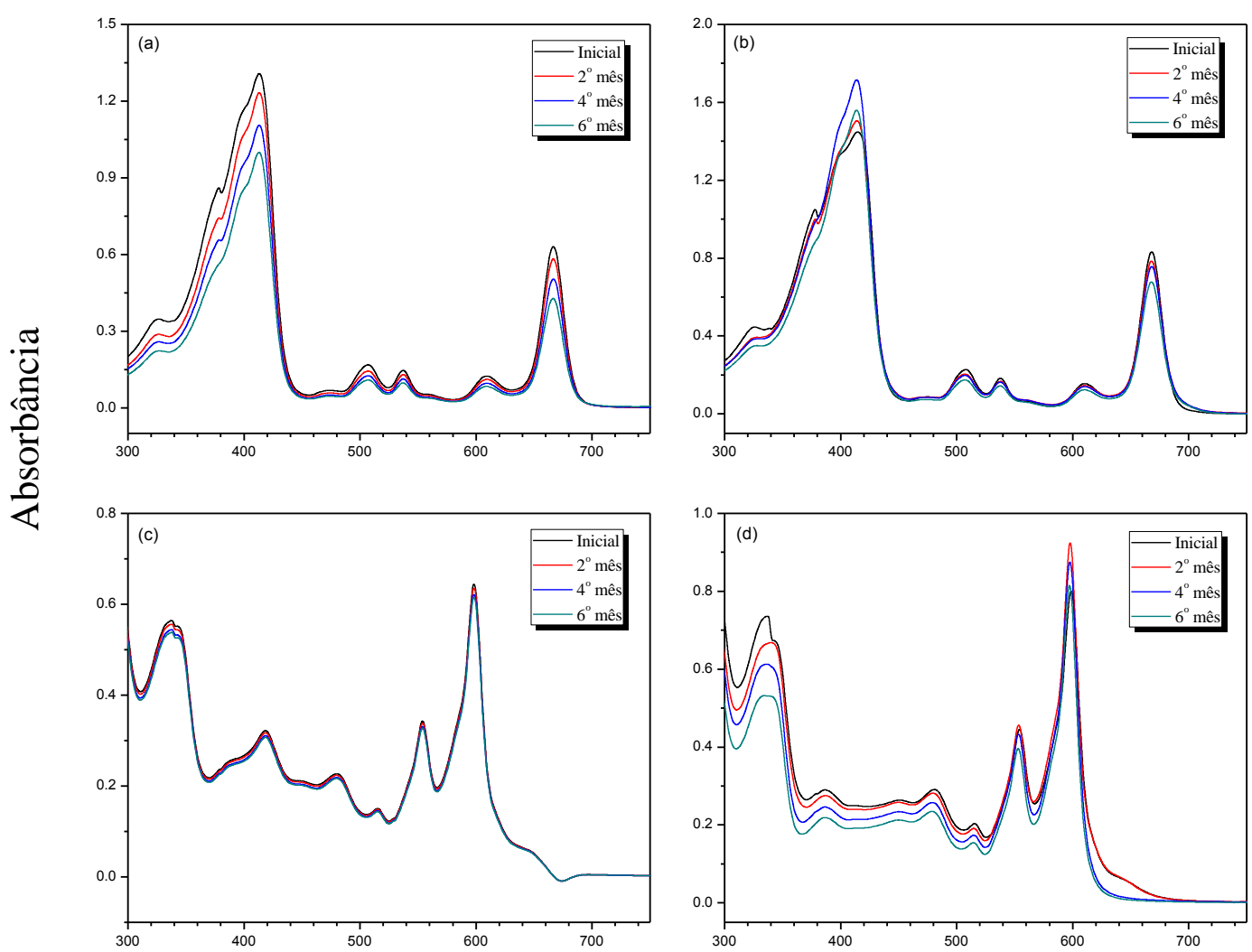

Comprimento de onda (nm) 
Com exceção da HY, observou-se que todos os espectros de absorção dos fotossensibilizadores apresentaram modificações em função do tempo, indicando uma possível degradação. Todavia, nenhuma banda adicional foi observada ao longo deste período. Posteriormente a um período de 180 dias, a diminuição da absorbância foi de cerca de $33 \%$ para a CHL, $29 \%$ para a CHL-T e 13\% para a HY-G. Devido a essas alterações corrigiu-se periodicamente a concentração da solução estoque através do coeficiente de absortividade molar (Tabela 5).

Tabela 5- Valores de coeficiente de absortividade molar para os fotossensibilizadores em DMSO.

\begin{tabular}{ccc}
\hline Fotossensibilizador & $\lambda$ & $(\varepsilon)\left(\times 10^{4} \mathrm{~L} \mathrm{~mol}^{-1} \mathrm{~cm}^{-1}\right)$ \\
\hline CHL & 667 & 2,29 \\
CHL-T & 667 & 7,29 \\
HY & 600 & 2,35 \\
HY-G & 600 & 2,60 \\
\hline
\end{tabular}

onde $\varepsilon$ é o coeficiente de absortividade molar e $\lambda$ é o comprimento de onda em que foi determinado $\varepsilon$.

\subsection{Análise da influência da força iônica em solução sobre os fotossensibilizadores}

Para analisar a influência da força iônica nas propriedades dos fotossensibilizadores em solução aquosa, obteve-se os espectros de absorção em função da concentração de $\mathrm{NaCl}$ (Figura 11).

Os espectros de absorção dos fotossensibilizadores sofreram influência da força iônica de maneira distinta. Para a CHL observou-se um discreto deslocamento batocrômico, isto é, um deslocamento para comprimentos de onda maiores, o decréscimo da banda de Soret e o alargamento da banda $\mathrm{Q}_{\mathrm{x}}(0,0)$ que indicaram o início do processo de agregação. No entanto, para os demais fotossensibilizadores este deslocamento espectral não ocorreu, porém foi observado um decréscimo na intensidade de absorção destes compostos em todas as bandas existentes no espectro. 
Figura 11: Espectros de absorção de (a) CHL, (b) CHL-T e (c) HY e (d) HY-G em função da concentração de $\mathrm{NaCl}, \mathrm{pH} \mathrm{7,0}$. Concentração do fotossensibilizadores $4,5 \times 10^{-6} \mathrm{~mol} \mathrm{~L}^{-1}$.

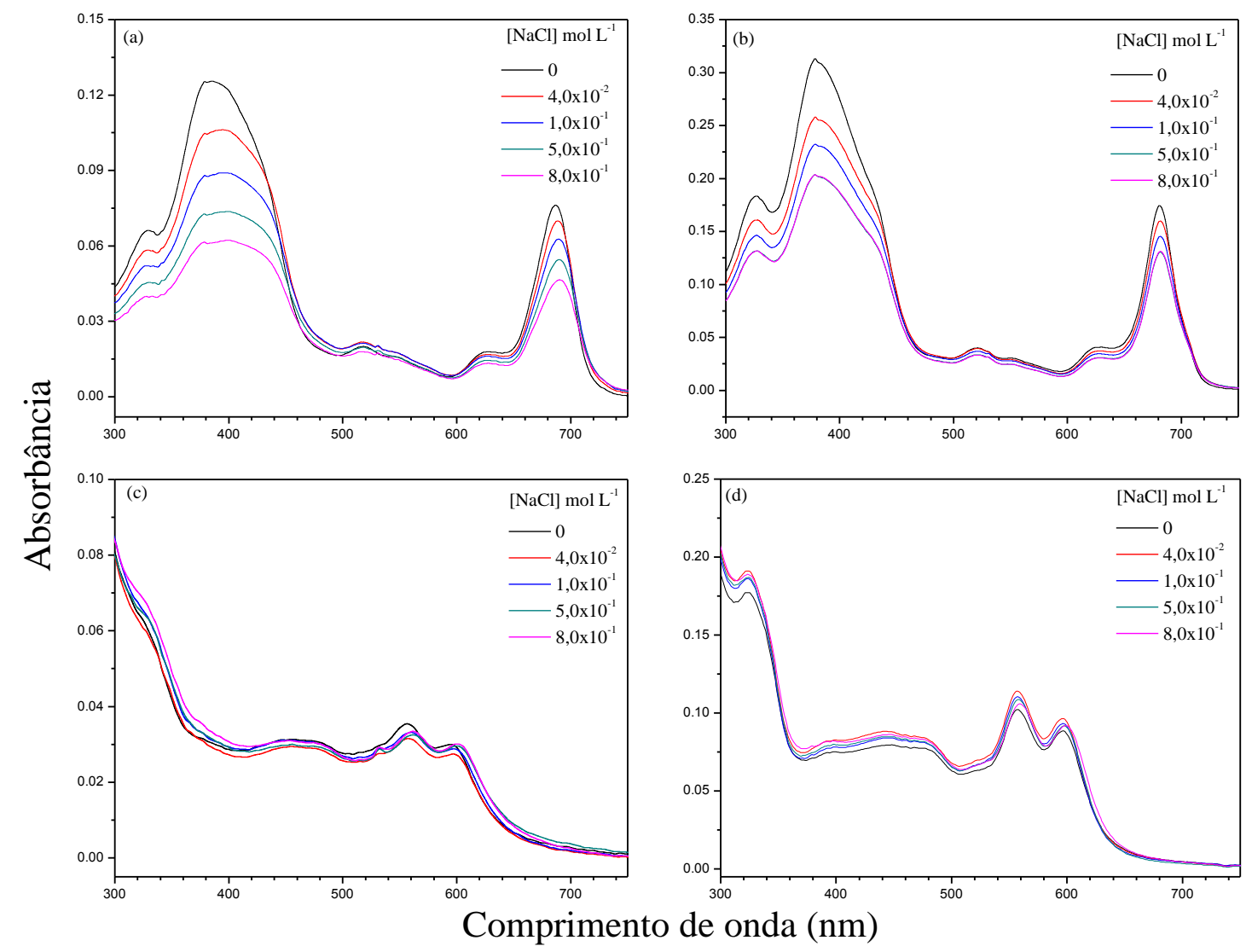

Os conjuntos de espectros experimentais da Figura 11 foram submetidos à análise computacional para a deconvolução de duas espécies distintas existentes em função da concentração de $\mathrm{NaCl}$ em solução. A concentração salina em que coexistem equivalentemente as duas espécies foi denominada concentração salina crítica (concentração crítica) e os valores para cada um dos fotossensibilizadores estão descritos na

Tabela 6.

Tabela 6- Valores de concentração salina crítica para os fotossensibilizadores.

\begin{tabular}{cc}
\hline Fotossensibilizador & Concentração crítica $\left(\times 10^{-2} \mathrm{~mol} \mathrm{~L}^{-1}\right)$ \\
\hline CHL & $5,08 \pm 1,10$ \\
CHL-T & $3,36 \pm 1,16$ \\
HY & $4,72 \pm 1,51$ \\
HY-G & $4,08 \pm 1,10$ \\
\hline
\end{tabular}


onde concentração crítica é a concentração salina em que coexistem equivalentemente as duas espécies.

Em todos os casos, a influência da força iônica ocorreu em concentrações superiores a $2,0 \times 10^{-2} \mathrm{~mol} \mathrm{~L}^{-1}$, portanto, assegura-se que a força iônica do tampão fosfato de sódio empregada neste trabalho não foi um fator relevante nos demais experimentos.

\subsection{Determinação da constante de partição dos fotossensibilizadores (P)}

O balanço lipofílico/hidrofílico de um fotossensibilizador desempenha um papel de importância crucial em sua biodistribuição, pois para gerar espécies citotóxicas ou ser empregado no diagnóstico por fluorescência, é necessário previamente que o composto penetre a membrana celular e se incorpore nas células doentes. No entanto, na maioria das vezes, os fotossensibilizadores são distribuídos de forma sistêmica pela corrente sanguínea sendo necessário que os compostos sejam solúveis no meio aquoso.

Para quantificar este balanço determinou-se a constante de equilíbrio de partição que, normalmente, é descrita pelo valor de seu logaritmo na base $10(\log \mathrm{P})$. O valor de $\log \mathrm{P}$ é diretamente proporcional ao grau de lipofilicidade da molécula. Portanto, os valores positivos de $\log \mathrm{P}$ indicam que os fotossensibilizadores difundem-se melhor através das membranas celulares (138).

Na Tabela 7 estão apresentados os valores de $\log \mathrm{P}$ para os fotossensibilizadores empregados no presente estudo calculados por meio da Equação 3 em sistema previamente saturado de 1-octanol/ tampão fosfato de sódio $2,0 \times 10^{-2} \mathrm{~mol} \mathrm{~L}^{-1}$.

Tabela 7- Coeficientes de partição calculados para os fotossensibilizadores $1,43 \times 10^{-5}$ mol L ${ }^{-1}$ utilizando-se o sistema previamente saturado de 1-octanol/ tampão fosfato de sódio $2,0 \times 10^{-2} \mathrm{~mol} \mathrm{~L}^{-1}, \mathrm{pH} \mathrm{7,0}$.

\begin{tabular}{cc}
\hline Fotossensibilizador & $\log \mathbf{P}$ \\
\hline CHL & $\infty^{*}$ \\
CHL-T & $-2,02 \pm 0,61$ \\
HY & $0,48 \pm 0,14$ \\
HY-G & $0,16 \pm 0,10$
\end{tabular}

*não houve partição. Onde $\log \mathrm{P}$ é o logaritmo da constante de partição. 
A ordem decrescente de lipofilicidade foi CHL> HY> HY-G>CHL-T. Valores positivos de $\log \mathrm{P}$ caracterizaram compostos lipofílicos (CHL), enquanto que valores negativos caracterizam compostos mais solúveis no meio aquoso (CHL-T). Sugere-se que valores próximos de zero como no caso de HY e HY-G indiquem substâncias com comportamentos de solubilidade intermediários.

Dentre os compostos empregados, a CHL apresentou um coeficiente de partição infinito, visto que os espectros de absorção foram iguais antes e após a partição, ou seja, a alta afinidade deste fotossensibilizador com a fase orgânica é tão acentuada que não permite que uma quantidade significativa deixe a fase orgânica para ser solubilizada na fase aquosa.

Comparando-se os pares CHL/CHL- T e HY/HY-G observou-se o decréscimo nos valores de $\log \mathrm{P}$ para os derivados. Isto comprova que ambas as modificações através da inserção de grupamentos hidrofílicos tornaram os derivados mais hidrossolúveis. Huang e colaboradores (139) descreveram que a partir da inserção de grupamentos hidrofílicos em bacterioclorinas foram observadas reduções nos valores de $\log$ P. Ormond e colaboradores (79) determinaram o valor de $\log \mathrm{P}$ para uma série análoga de porfirinas anfifílicas e observaram que a substituição do grupamento $p$-OH por um grupo mais hidrofílico $p$ - $\mathrm{NHSO}_{2} \mathrm{Me}$ reduziu a lipofilicidade de 4,03 $\pm 0,18$ para $2,33 \pm 0,41$.

\subsection{Processo de autoagregação dos fotossensibilizadores}

O processo de autoagregação em solução é comumente observado para corantes devido as atrações intermoleculares do tipo Van der Walls. Uma das formas de identificação deste processo é por espectroscopia. Os agregados tendem a exibir mudanças espectrais quando comparados à forma monomérica do composto.

A Figura 12 apresenta os espectros de absorção dos fotossensibilizadores em função de sua concentração entre $1,00 \times 10^{-6}$ a $1,00 \times 10^{-5}$ mol L ${ }^{-1}$ em tampão fosfato de sódio $2,0 \times 10^{-2} \mathrm{~mol} \mathrm{~L}^{-1} \mathrm{pH} \mathrm{7,0.}$ 
Figura 12: Absorbância em $\lambda$ em função concentração dos fotossensibilizadores, em tampão fosfato de sódio $2,0 \times 10^{-2} \mathrm{~mol} \mathrm{~L}^{-1}$ e $\mathrm{pH} 7,0(\lambda=690 \mathrm{~nm}$ para $\mathrm{CHL}, 680 \mathrm{~nm}$ para CHL-T e 556nm para HY e HY-G).

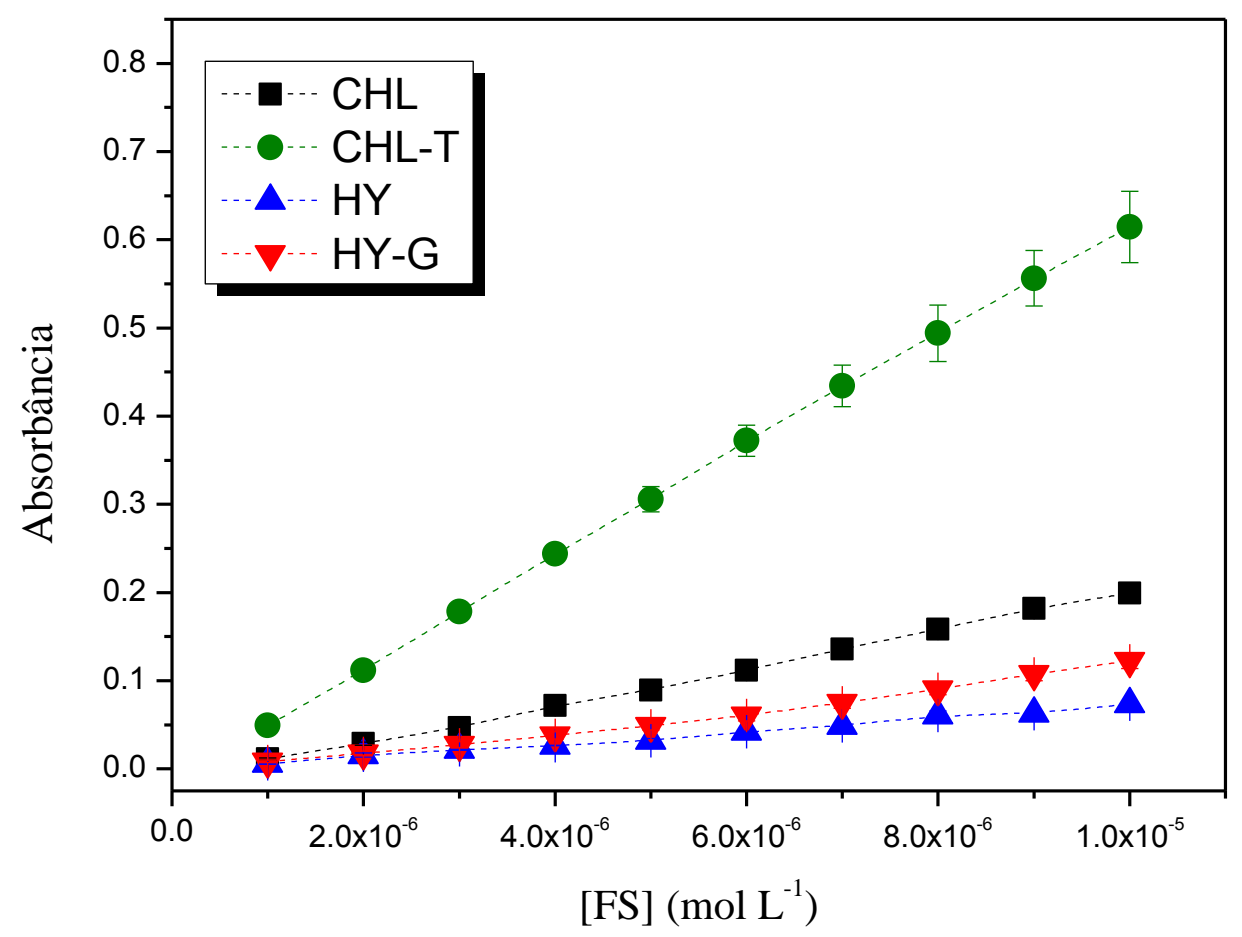

Para todos os fotossensibilizadores estudados não foram observadas mudanças espectrais, cujos deslocamentos para o vermelho poderiam indicar a formação de agregados do tipo $\mathbf{J}$ (cabeça-cauda) e se ocorressem para o azul seria do tipo $\mathrm{H}$ (empilhamento face a face). (140). Concomitantemente, observou-se a relação linear entre intensidade de absorção e as concentrações dos fotossensibilizadores, o que caracteriza a obediência à lei de Beer-Lambert na faixa de concentração estudada.

A Tabela 8 exibe os coeficientes de absortividade molar calculados para os fotossensibilizadores através do modelo matemático de regressão linear.

Tabela 8- Valores de coeficiente de absortividade molar para os fotossensibilizadores em tampão fosfato de sódio $2,0 \times 10^{-2} \mathrm{~mol} \mathrm{~L}^{-1}$, pH 7,0.

\begin{tabular}{ccc}
\hline Fotossensibilizador & $\lambda$ & $(\varepsilon)\left(\times 10^{4} \mathrm{~L} \mathrm{~mol}^{-1} \mathrm{~cm}^{-1}\right)$ \\
\hline CHL & 690 & $2,16 \pm 0,09$ \\
CHL-T & 680 & $6,31 \pm 0,48$ \\
HY & 556 & $0,73 \pm 0,03$ \\
HY-G & 556 & $1,27 \pm 0,07$ \\
\hline
\end{tabular}

onde $\varepsilon$ é o coeficiente de absortividade molar e $\lambda$ é o comprimento de onda em que foi determinado $\varepsilon$. 
De acordo com a lei de Beer-Lambert, sugere-se que a solubilidade destes compostos em meio aquoso seja parcial, pois houve o aumento linear da absorbância em função da concentração, porém os valores de $\varepsilon$ são inferiores àqueles obtidos em DMSO.

Segundo Margalit e colaborados (9), a espectroscopia de emissão de fluorescência pode-se apresentar como uma técnica mais sensível para a identificação de agregados de fotossensibilizadores em solução do que a espectroscopia de absorção. No entanto, como descrito no item 5.1, os fotossensibilizadores empregados neste estudo apresentam baixa emissão de fluorescência em meio aquoso. Portanto, avaliou-se a influência da porcentagem de água em solução diluída de fotossensibilizadores em DMSO utilizando-se espectroscopia de emissão de fluorescência (Figura 13).

Figura 13: Espectros de emissão de fluorescência de soluções em DMSO de (a) CHL, (b) CHL-T, (c) HY e (d) HY-G em função da porcentagem de água em solução. (CHL e CHL-T $\lambda_{\text {ex }}=610 \mathrm{~nm}$ e HY e HY-G $\lambda_{\text {ex }}=545 \mathrm{~nm}$ )
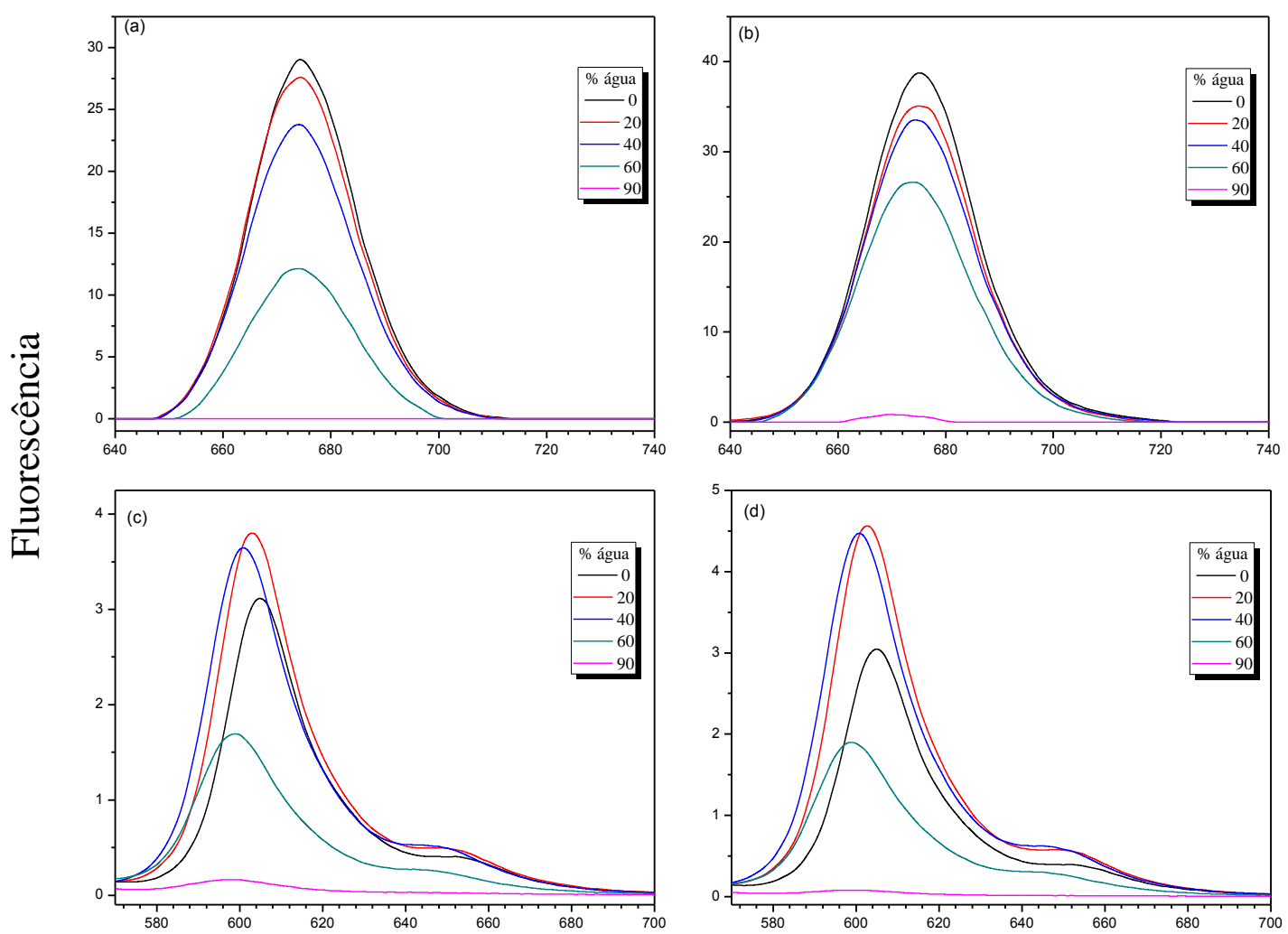

Comprimento de onda (nm)

Como previamente descrito no item 5.1, os fotossensibilizadores CHL e CHL-T solubilizados em DMSO $\left(\lambda_{\mathrm{ex}}=610 \mathrm{~nm}\right)$ exibiram uma banda de fluorescência entre 665 - 
$695 \mathrm{~nm}$ que foi fortemente suprimida com a adição de água em solução. Este comportamento espectral sugere a formação de agregados em solução. No caso das duas bandas de emissão de fluorescência para as hipericinas, além da supressão foi observado deslocamento hipsocrômico que sugere a formação de agregados do tipo H. (140). A presença de um ponto isosbéstico localizado em $633 \mathrm{~nm}$ indica a existência de ao menos duas espécies fluorescentes distintas neste equilíbrio (141).

Confrontando-se os valores da fluorescência integrada dos espectros de emissão dos fotossensibilizadores em função da porcentagem de água em solução (Figura 14) observou-se que para todos os compostos há um patamar até cerca de $40 \%$ de água em solução em que se há fluorescência praticamente constante. Em seguida, inicia-se o processo de supressão de fluorescência não linear com o aumento da porcentagem de água em solução.

Figura 14: Fluorescência integrada de (a) CHL e CHL-T e (b) HY e HY-G em função da porcentagem de água em solução.

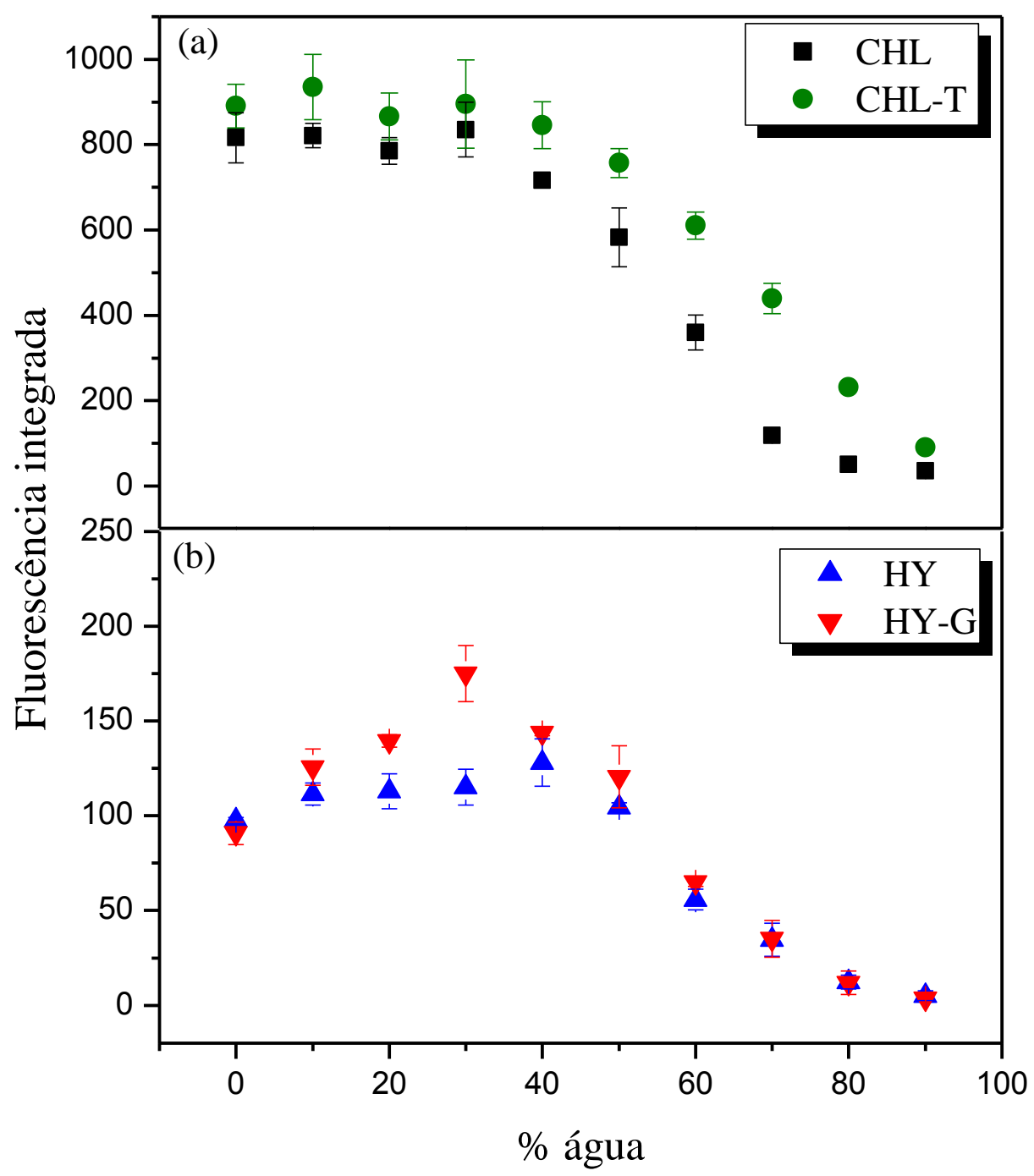


Aplicando-se o método da primeira derivada para as curvas demonstradas na Figura 14, determinou-se a porcentagem de água limite em solução que o fotossensibilizador encontra-se na forma não agregada, chamado de porcentagem de água crítica (\% crítica) (Tabela 9).

Tabela 9- Valores de \% de água críticos para solubilização dos fotossensibilizadores.

\begin{tabular}{cl}
\hline Fotossensibilizador & $\%$ crítica \\
\hline CHL & $60,0 \pm 0,1$ \\
CHL-T & $70,0 \pm 0,1$ \\
HY & $49,8 \pm 0,3$ \\
HY-G & $59,9 \pm 0,3$ \\
\hline
\end{tabular}

onde $\%$ crítica é a porcentagem de água limite em solução em que os fotossensibilizadores são parcialmente solúveis.

De uma forma geral, todos os fotossensibilizadores sofreram o processo de agregação quando adicionou-se água em solução. Contudo, observou-se que os fotossensibilizadores precursores foram mais suscetíveis a este processo. No caso das clorinas, observou-se que a CHL-T permaneceu solúvel em 16,7\% a mais de água do que a CHL. Já para a HY-G esse aumento foi de 20,3\% em relação à HY. Estes resultados corroboram com a hipótese previamente formulada pelos experimentos de $\log \mathrm{P}$.

\subsection{Influência do pH no meio reacional}

Em meio aquoso, a estrutura planar e a grande área superficial dos fotossensibilizadores podem favorecer a agregação destes compostos (142). Estas formações dos agregados são diretamente influenciadas pelas distribuições de cargas do meio reacional, e consequentemente do $\mathrm{pH}$. Para investigar as diferentes formas coexistentes da CHL, CHL-T, HY e HY-G variando-se o pH de 1,0 a 13,0, o comportamento espectral destes fotossensibilizadores foi monitorado visando-se a detecção de cargas elétricas e uma possível formação de agregados.

A Figura 15 ilustra os espectros de absorção em solução aquosa dos fotossensibilizadores CHL e CHL-T em função do pH (solução tampão de fosfato de sódio $2,0 \times 10^{2} \mathrm{~mol} \mathrm{~L}^{-1}$ ). 
Figura 15: Espectros de absorção da (a) CHL e (b) CHL-T em função do pH em solução de fosfato de sódio $2,0 \times 10^{-2} \mathrm{~mol} \mathrm{~L}^{-1}$. (Fotossensibilizadores $6,5 \times 10^{-6} \mathrm{~mol} \mathrm{~L}^{-1}$ ).

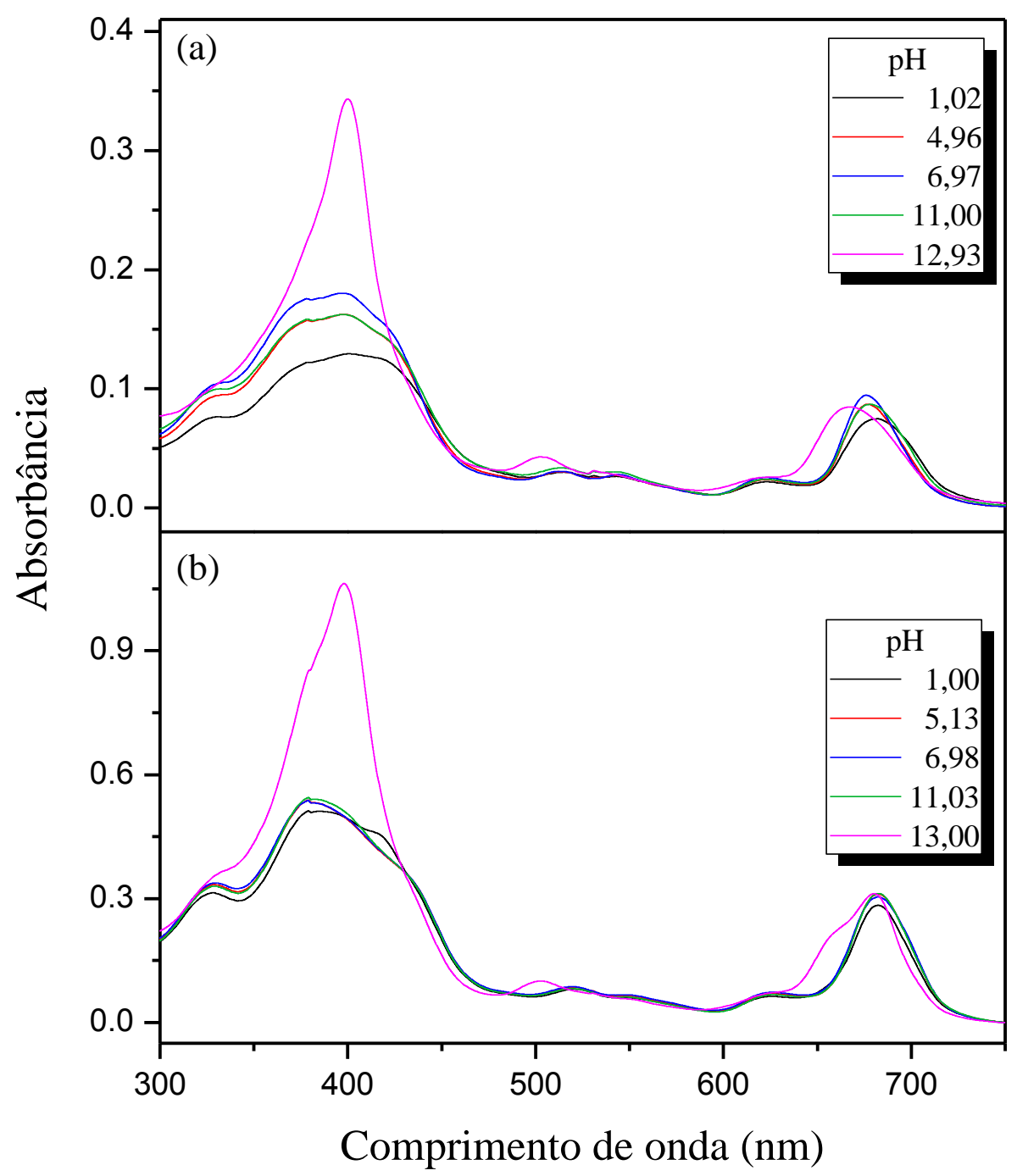

Para a CHL em pH 7,0 identificou-se a banda de Soret centrada em 397 nm e quatro bandas Q centradas em 514, 543, 618 e 677 nm. Em pH ácido houve uma diminuição da intensidade de todas as bandas de absorção dos espectros e um discreto deslocamento para comprimento de ondas maiores da banda $\mathrm{Q}_{\mathrm{x}}(0,0)$. Em $\mathrm{pH}$ extremamente alcalino, observou-se um deslocamento hipsocrômico desta banda de absorção, ou seja, um deslocamento espectral para comprimentos de ondas menores e, ainda, um suposto afinamento da banda de Soret que foram atribuídos à desagregação ou predomínio de uma das espécies de uma mistura.

Para a CHL-T a banda de Soret foi observada em $380 \mathrm{~nm}$ e as bandas Q centradas em 520, 553, 622 e $681 \mathrm{~nm}$. Em meio ácido houve um ligeiro aumento da intensidade de absorção de todas as bandas, porém não foram observados 
deslocamentos espectrais. Com a alcalinização da solução, ocorreu uma diminuição sutil da intensidade de absorção e um ligeiro deslocamento hipsocrômico. Analogamente à $\mathrm{CHL}$, em pH extremamente alcalino observou-se ainda um alargamento da banda $\mathrm{Q}_{(0,0)}$ e o afinamento da banda de Soret para a CHL-T.

A presença de um ponto isosbéstico localizado em $671 \mathrm{~nm}$ em $\mathrm{pH}$ alcalino indicou a existência de ao menos duas espécies distintas neste equilíbrio (141). Confrontando-se a absorbância da banda de Soret para CHL e CHL-T em função do pH (Figura 16), observou-se a presença de pelo menos três espécies em equilíbrio. Além dos deslocamentos espectrais supracitados, a intensidade desta banda aumenta drasticamente em $\mathrm{pH}$ alcalino. A região compreendida entre $\mathrm{pH}$ 4,5 a 8,5 sugere a existência de uma espécie intermediária.

Figura 16: Absorbância em $368 \mathrm{~nm}$ para (a) CHL e (b) CHL-T em função do pH. (Tampão fosfato de sódio $2,0 \times 10^{-2} \mathrm{~mol} \mathrm{~L}^{-1}$ ).

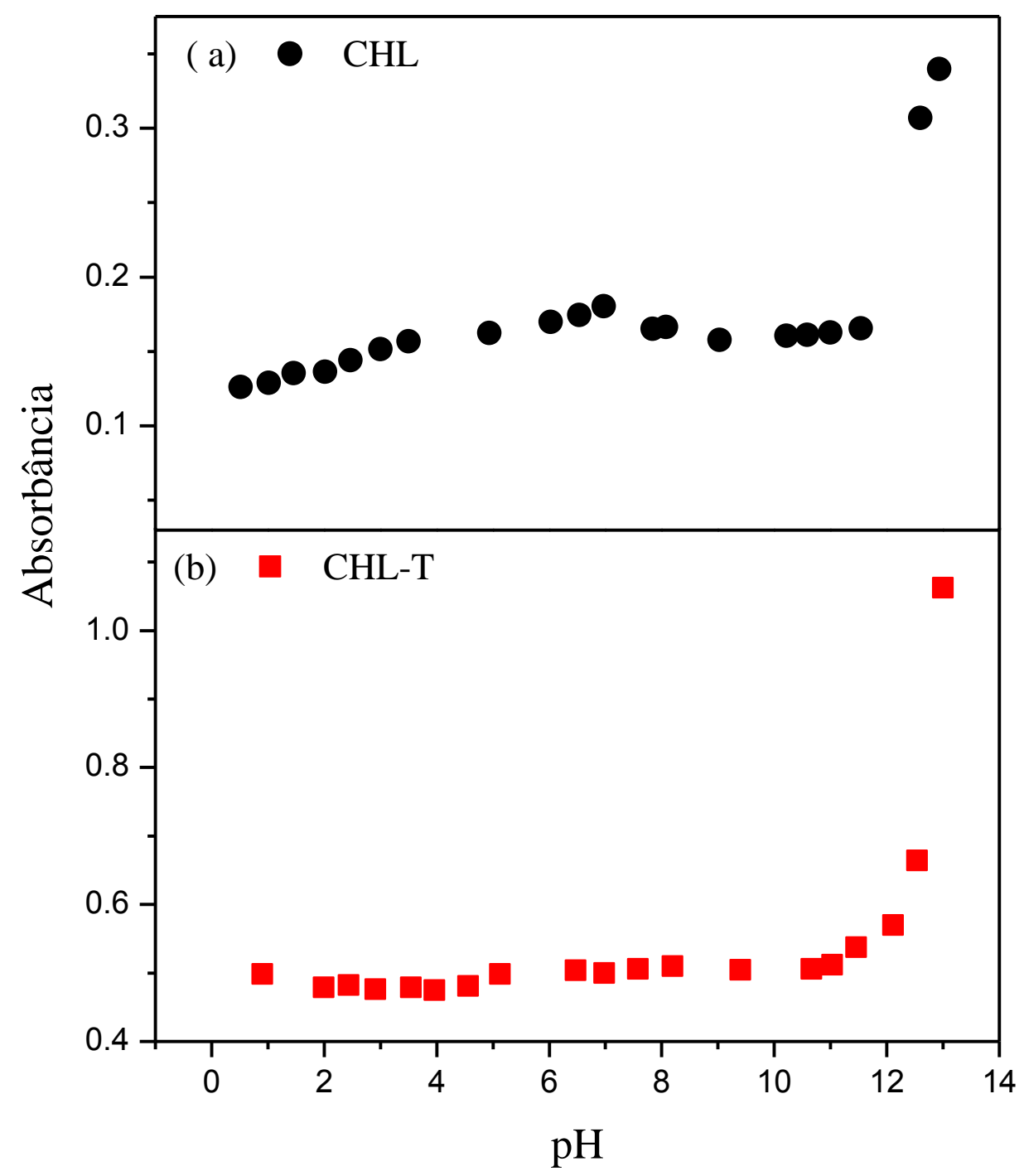


Sugere-se que o equilíbrio em solução existente para as clorinas seja composto por duas transições distintas, conforme descrito no esquema abaixo:

$$
\begin{array}{lr}
C H L(T)^{+2} \rightleftharpoons C H L(T)^{0}+2 H^{+} & \text {Equação } 9 \\
C H L(T)^{0} \rightleftharpoons C H L(T)^{-2}+2 H^{+} & \text {Equação } 10
\end{array}
$$

A transição em meio ácido é impreterivelmente atribuída à protonação dos nitrogênios ionizáveis localizados na região central do macrociclo porfirínicos (143, 144) e a transição em meio alcalino é proveniente da desprotonação dos nitrogênios pirrólicos (144) e/ou da ruptura no anel macrocíclico.

Este processo de protonação/desprotonação é ratificado pelo fato destes fotossensibilizadores não sofrerem histerese química em meio ácido. A histerese é o processo em que uma substância altera suas propriedades quando submetidos a um estímulo. Neste caso, as clorinas conservaram suas características espectrais em pH 7,0 após serem drasticamente acidificadas. Contudo, posteriormente a drástica alcalinização não foi possível retornar ao espectro inicial em $\mathrm{pH} 7,0$, indicando assim mudanças na estrutura química destas moléculas.

Baseado neste modelo, os conjuntos de espectros experimentais da Figura 15 foram submetido à análise computacional para a deconvolução das três componentes puras em função do $\mathrm{pH}$. Para a CHL, atribuiu-se a forma protonada ao espectro com a banda $\mathrm{Q}_{(0,0)}$ centrada em $692 \mathrm{~nm}$, neutra centrada em $678 \mathrm{~nm}$ e para a desprotonada em $668 \mathrm{~nm}$. Através da contribuição de cada uma das espécies em função do pH obteve-se os valores de $\mathrm{pK}_{1}=3,77 \pm 0,76$ e $\mathrm{pK}_{2}=12,65 \pm 0,19$ (Figura 17). Similarmente, a análise de deconvolução para a CHL-T resultou em $\mathrm{pK}_{1}=4,96 \pm 0,81$ e $\mathrm{pK}_{2}=12,76 \pm 0,18$. 
Figura 17: (a) Componentes da deconvolução dos espectros de absorção da CHL (fosfato de sódio $2,0 \times 10^{-2} \mathrm{~mol} \mathrm{~L}^{-1}$ ) e (b) contribuições das frações destas espécies existentes no equilíbrio em função do $\mathrm{pH}$.
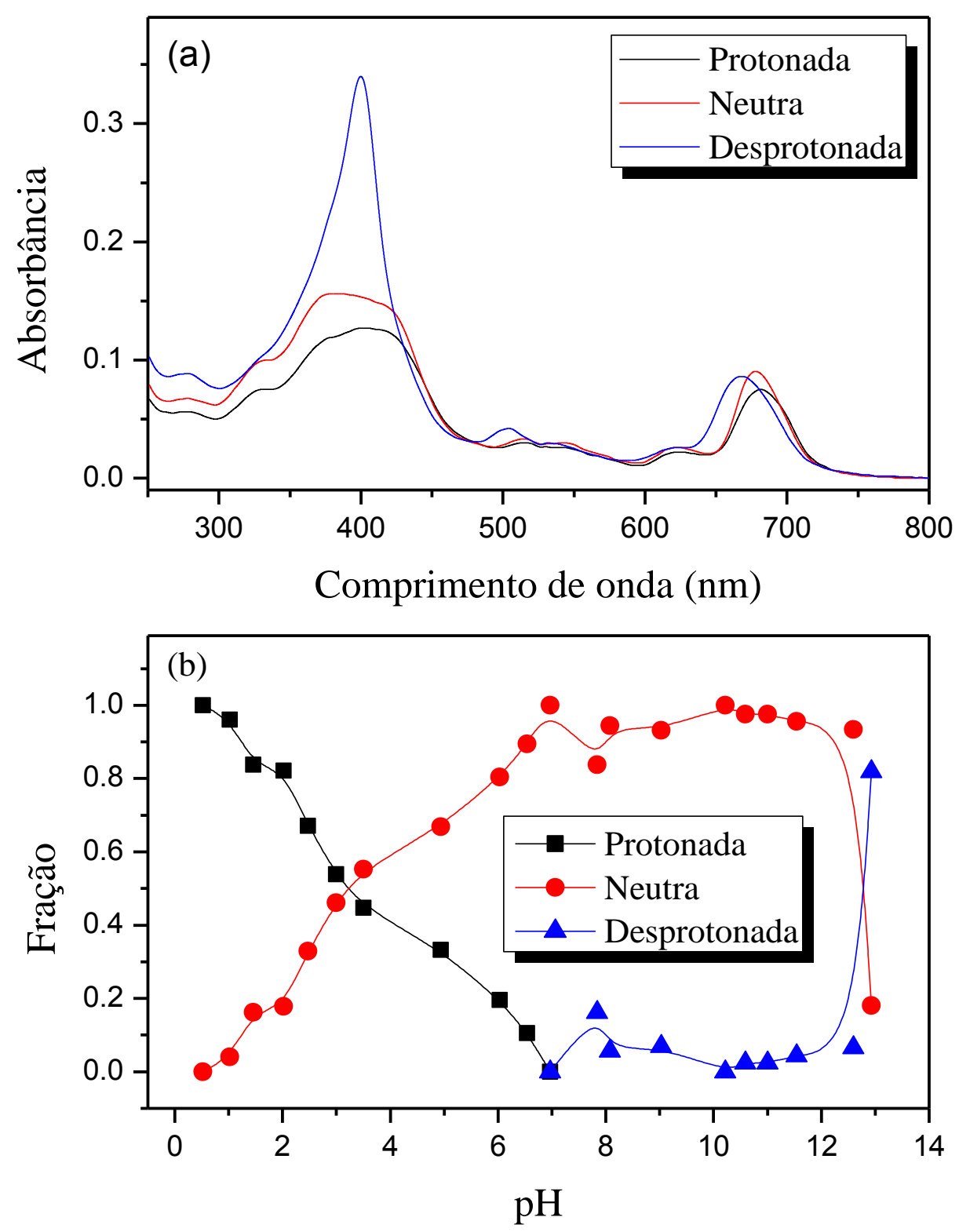

Em geral, os derivados porfirínicos do tipo base-livre sofrem protonação ou desprotonação influenciados pelo pH da solução. Cunderlikova e colaboradores (144) determinaram o pK da transição da protonação dos nitrogênios do macrociclo para as porfirina TPPS $_{4}$ e mTHPP e para a clorina mTHPC como sendo 5,1; 3,8 e 2,4, respectivamente. Lilletvedt e colaboradores analisaram espectroscopicamente as propriedades físico-químicas e de agregação para a clorina $\mathrm{TPCS}_{2 \mathrm{a}}$ e sua porfirina

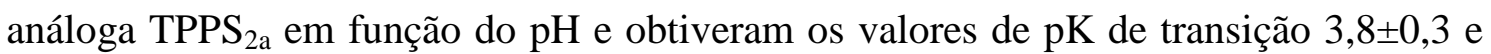

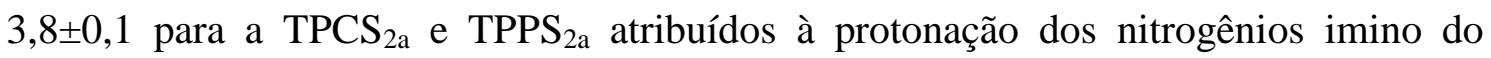
macrociclo porfirínicos (143). Datta e colaboradores (145) observaram que a protonação 
dos grupos carboxílicos ionizáveis da clorina mTHPC devido à diminuição do $\mathrm{pH}$ acarreta no aumento da hidrofobicidade da molécula e consequentemente na agregação. Ressalta-se que não existem grupos carboxílicos ionizáveis para as clorinas empregadas neste estudo visto que foram substituídos por metilas.

Os espectros de emissão de fluorescência das clorinas apresentaram mudanças significativas com a variação do $\mathrm{pH}$ da solução (Figura 18). A baixa emissão de fluorescência em meio aquoso das clorinas em pH 7,0 indicou que não existem cargas elétricas na molécula nestas condições e que devido a sua baixa solubilidade, estes fotossensibilizadores possam estar segregados da solução. Em $\mathrm{pH}$ extremos foi observada a emissão de fluorescência, sugerindo que nestas condições estes compostos estejam solúveis.

Figura 18: Espectros de emissão de fluorescência da (a) CHL e (b) CHL-T em função do pH. (Tampão de fosfato de sódio $2,0 \times 10^{-2} \mathrm{~mol} \mathrm{~L}^{-1}$ e $\lambda_{\mathrm{ex}}=610 \mathrm{~nm}$ ).

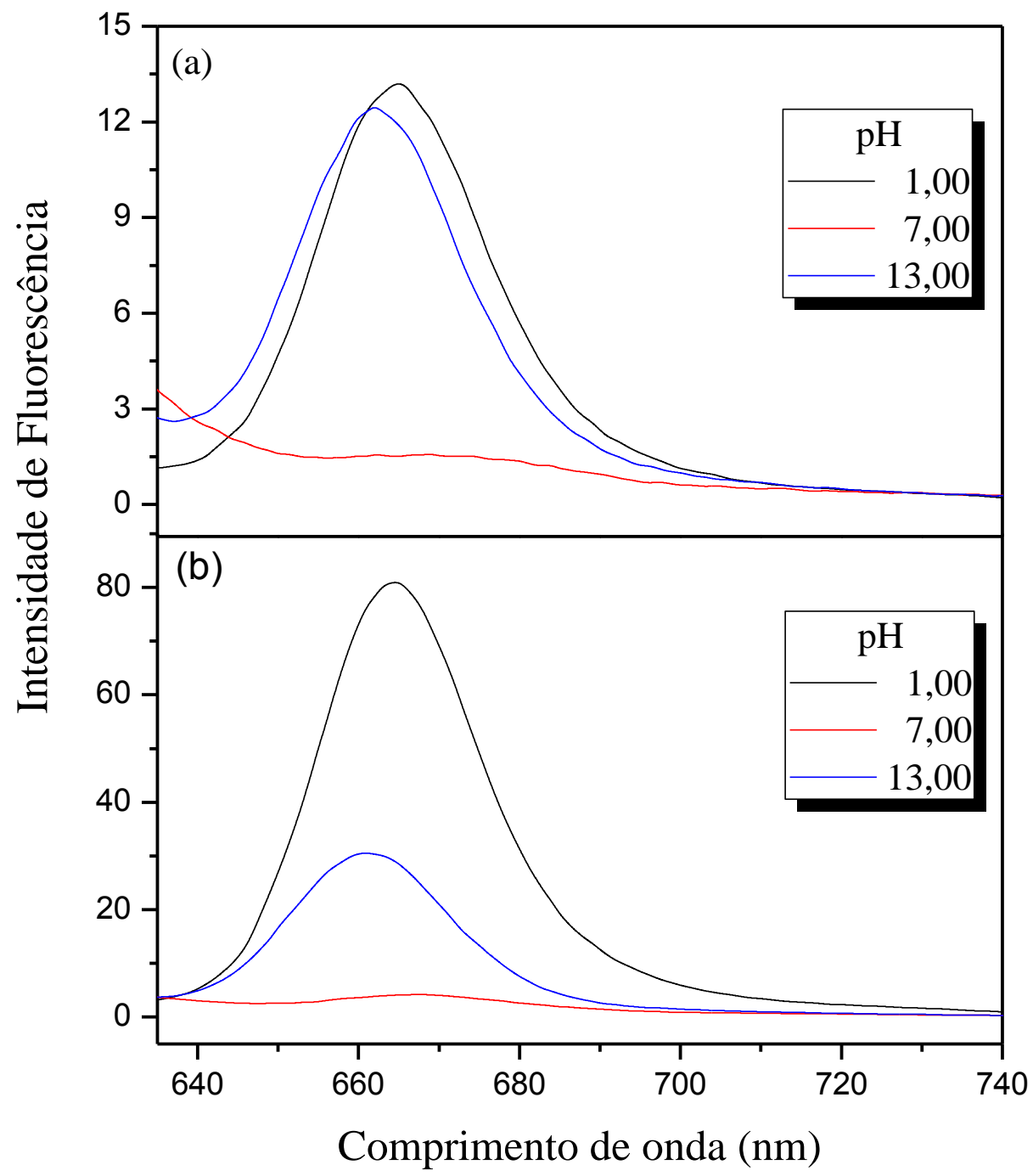


Estas observações corroboram com o modelo previamente proposto em que as clorinas coexistem como três espécies distintas, sendo que predominantemente como agregados em $\mathrm{pH}$ neutro e como monômeros em $\mathrm{pH}$ extremos.

Analogamente às clorinas, as hipericinas também foram influenciadas pelo $\mathrm{pH}$ do meio. Os espectros de absorção da titulação da HY e HY-G, em solução tampão de fosfato de sódio $2,0 \times 10^{-2} \mathrm{~mol} \mathrm{~L}^{-1}$, em função do pH estão ilustrados na Figura 19.

Figura 19: Espectros de absorção da (a) HY e (b) HY-G em solução de fosfato de sódio $2,0 \times 10^{-2}$ mol L-1 em função do pH. (HY 5,0 $\times 10^{-6} \mathrm{~mol} \mathrm{~L}^{-1}$ e HY-G $1,1 \times 10^{-5} \mathrm{~mol} \mathrm{~L}^{-1}$ ).

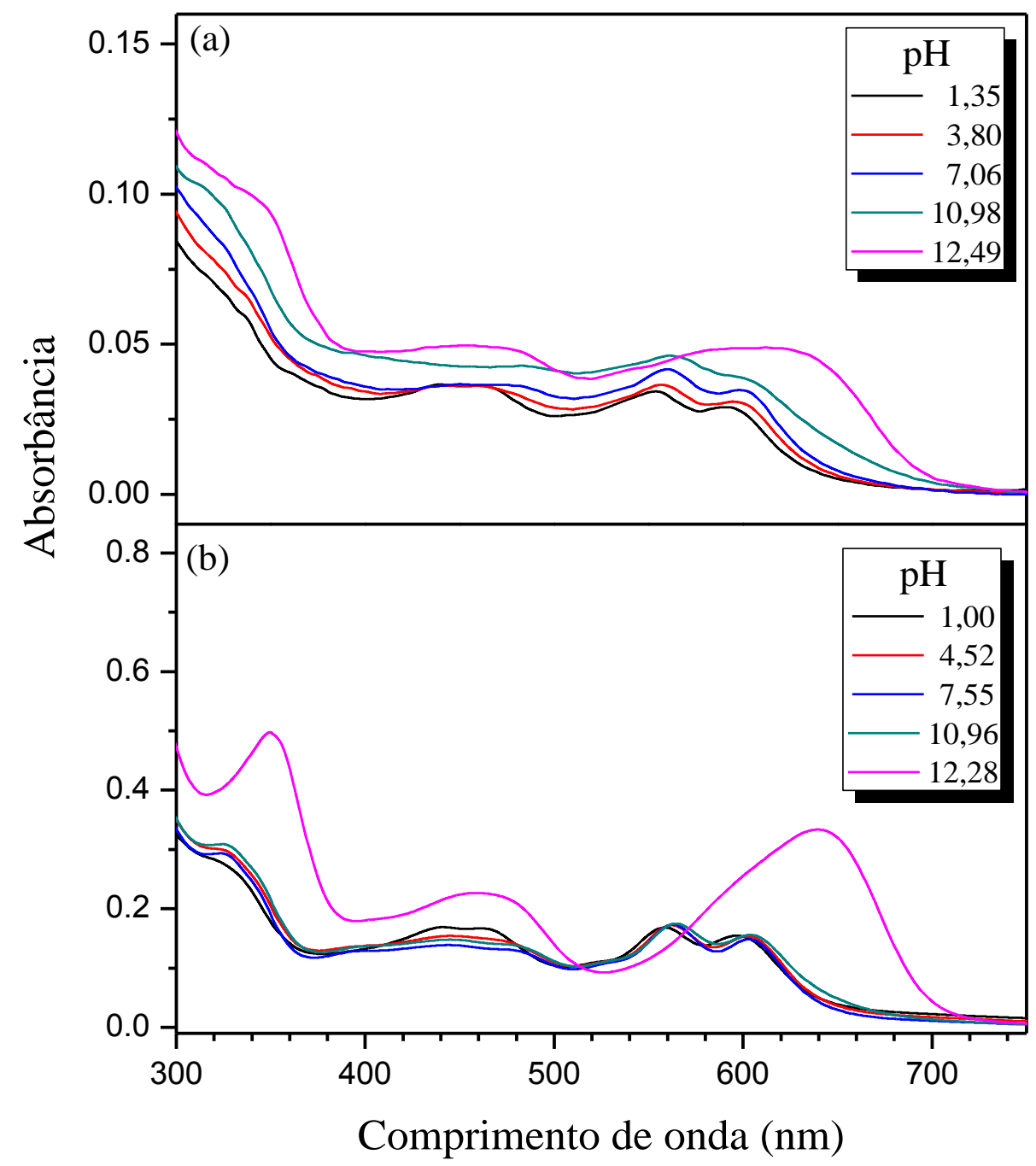

Em pH 7,0, estes compostos apresentaram uma banda de absorção alargada na região do ultravioleta compreendida entre 314 e $370 \mathrm{~nm}$, uma banda ao redor de $450 \mathrm{~nm}$ e as duas bandas principais centradas em 556 e $598 \mathrm{~nm}$ atribuídas à forma agregada e 
monomérica, respectivamente (item 5.1). Nestas condições, sugere-se que estes compostos estejam agregados de forma a compor um empilhamento de moléculas (agregados do tipo H) devido à interação intermolecular dos elétrons $\pi$ presentes na estrutura (146).

Em meio ácido, observou-se uma diminuição da intensidade de absorção de todas as bandas presentes no espectro e um ligeiro deslocamento espectral para comprimento de ondas menores. Estes deslocamentos sugerem que estes compostos possam estar na forma de agregados do tipo H. Além disso, a banda de maior intensidade foi a que previamente atribuiu-se à forma agregada. (147).

Contudo, em pH extremamente alcalino ocorreu a supressão da banda de absorção atribuída ao agregado e houve um aumento de intensidade do sinal e alargamento da banda atribuída a forma monomérica das hipericinas. Observou-se ainda um deslocamento espectral desta banda de absorção para comprimentos de onda maiores e o afinamento da banda de absorção na região do ultravioleta.

Um ponto isosbéstico localizado $570 \mathrm{~nm}$ foi observado em $\mathrm{pH}$ alcalino, indicando a transição entre ao menos duas espécies neste equilíbrio. Confrontando-se a absorbância $(600 \mathrm{~nm})$ em função do $\mathrm{pH}$ observou-se a presença de pelo menos três espécies em equilíbrio. (Figura 20).

Deste modo, sugere-se que o equilíbrio existente para as hipericinas na faixa de pH estudada seja composto por duas transições, conforme descrito no esquema abaixo:

$$
\begin{aligned}
& H Y(G)^{0} \rightleftharpoons H Y(G)^{-1}+1 H^{+} \quad \text { Equação } 11 \\
& H Y(G)^{-1} \rightleftharpoons H Y(G)^{-2}+1 H^{+} \quad \text { Equação } 12
\end{aligned}
$$

A primeira transição é atribuída à retirada de um próton da região de baía da molécula, e a segunda é referente a desprotonação existente na periferia da molécula (87, 147). Estas observações podem ser ratificadas uma vez que as hipericinas sofrem histerese química, conservando as propriedades espectrais quando submetidas à $\mathrm{pH}$ extremos. 
Figura 20: Absorbância em 600 nm para (a) HY e (b) HY-G em função do pH. (Tampão fosfato de sódio $2,0 \times 10^{-2} \mathrm{~mol} \mathrm{~L}^{-1}$ ).

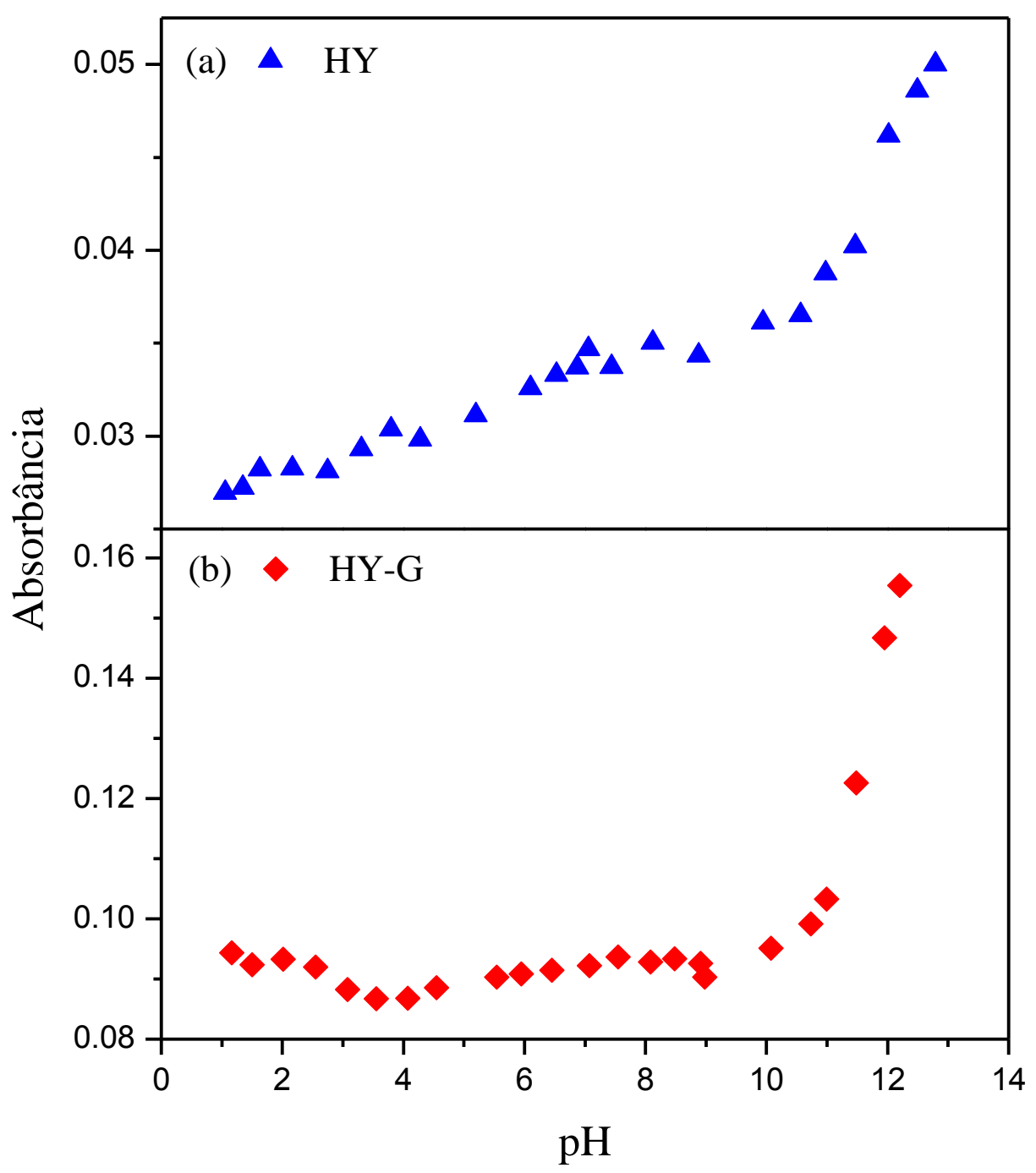

Os conjuntos de espectros da Figura 19 foram submetidos à análise de deconvolução computacional anteriormente descrita para as clorinas considerando-se a existência da combinação de três componentes puras em solução proposto pelo modelo. As três espécies identificadas foram denominadas forma neutra, forma aniônica e forma dianiônica. A contribuição de cada uma das espécies em função do pH resultou nos valores de $\mathrm{pK}_{1}=3,49 \pm 0,26$ e $\mathrm{pK}_{2}=11,89 \pm 0,52$ para a $\mathrm{HY}$ e de $\mathrm{pK}_{1}=3,01 \pm 0,16$ e $\mathrm{pK}_{2}=$ $11,41 \pm 0,33$ para a HY-G (Figura 21). 
Figura 21: (a) Componentes da deconvolução dos espectros de absorção da HY-G (fosfato de sódio $2,0 \times 10^{-2} \mathrm{~mol} \mathrm{~L}^{-1}$ ) e (b) contribuições das frações destas espécies existentes no equilíbrio em função do $\mathrm{pH}$.
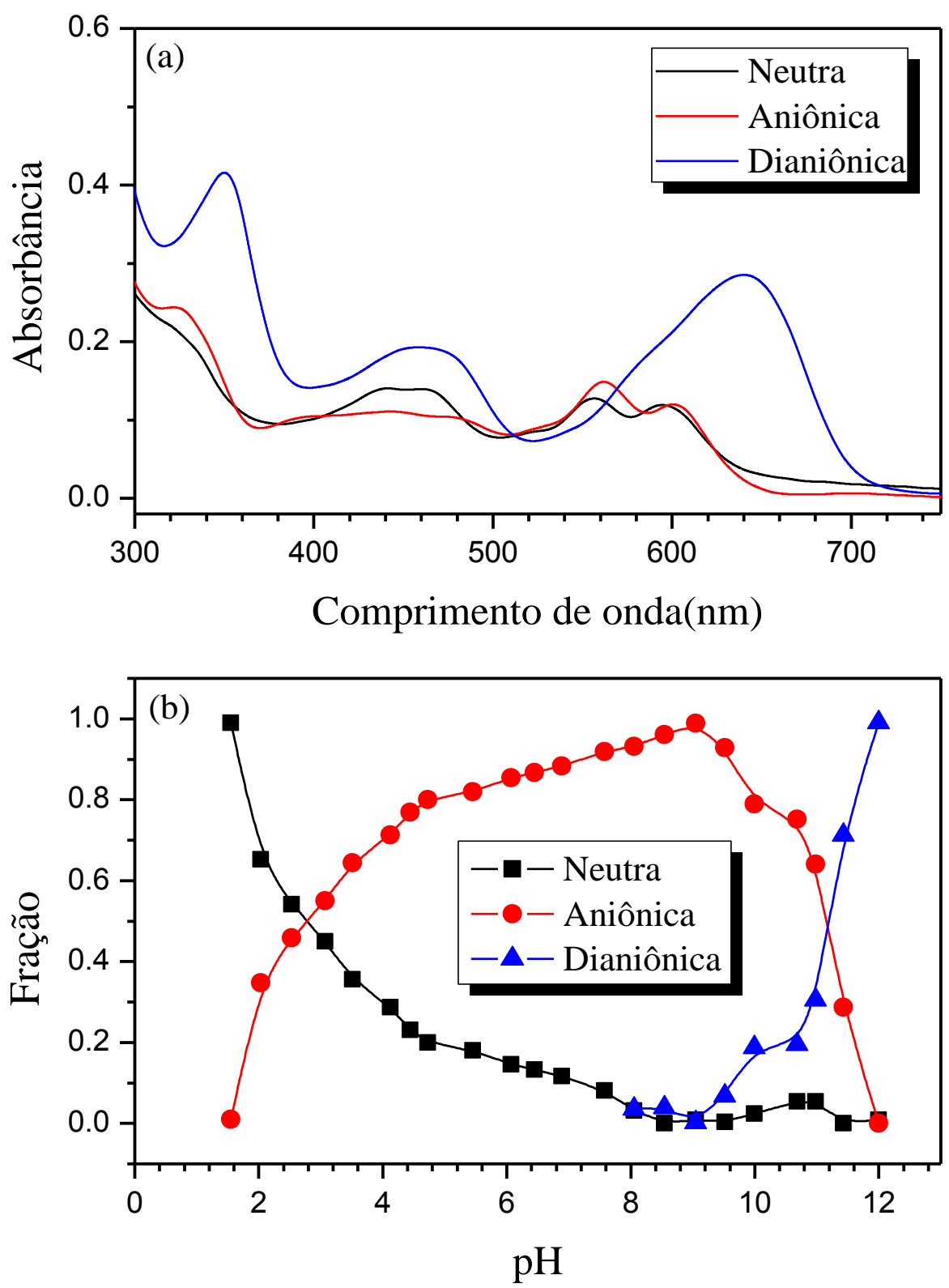

Os espectros de emissão de fluorescência das hipericinas em tampão fosfato de sódio $2,0 \times 10^{-2} \mathrm{~mol} \mathrm{~L}^{-1}$ também sofreram influência do $\mathrm{pH}$ do meio (Figura 22).

Em pH neutro e ácido a intensidade de emissão de fluorescência foi extremamente baixa. Isto pode ser explicado devido a formação de agregados do tipo $\mathrm{H}$ nas hipericinas. Agregados desta natureza acarretam em notável supressão de fluorescência em solução. Todavia, em pH alcalino observou-se uma banda de emissão de fluorescência intensa centrada em 673 nm que pode ser atribuída à forma dianiônica 
das hipericinas, uma vez que a autoagregação desta espécie é dificultada devido à existência de cargas elétricas nas moléculas (147).

Figura 22: Espectros de emissão de fluorescência da (a) HY e (b) HY-G em função do pH. (Tampão de fosfato de sódio $2,0 \times 10^{-2} \mathrm{~mol} \mathrm{~L}-1$ e $\lambda \mathrm{ex}=545 \mathrm{~nm}$ ).

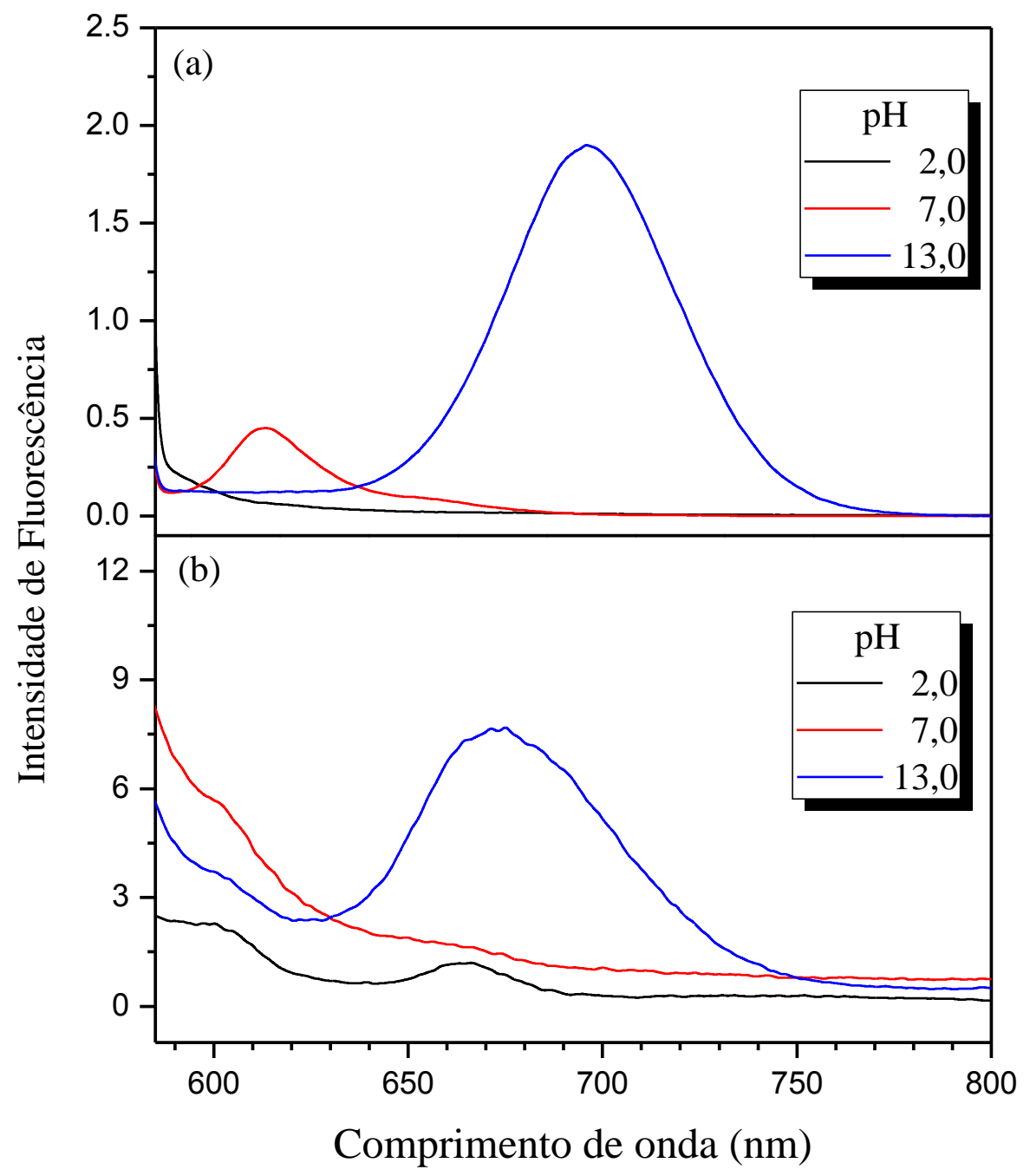

As transições existentes em função do pH observadas para a HY e seu derivado foram descritas de modo similar previamente na literatura. Freeman e colaboradores (148) estudaram espectroscopicamente as propriedades da hipericina e de um derivado no estado fundamental e excitado em função do $\mathrm{pH}$ e observaram que a desprotonação ocorre em ambos os estados. Para a hipericina foram identificadas três espécies em solução com $\mathrm{pK}_{1}=1,7$ e $\mathrm{pK}_{2}=12,5$. No entanto, para o derivado foram identificadas quatro espécies cujos valores de pK de transição foram 1,6; 3,6 e 13,2. Outro derivado 
de hipericina com solubilidade melhorada foi estudado por Altman e Falk (87). A presença de três espécies coexistentes em função do $\mathrm{pH}$ foram observadas, atribuídas a forma neutra, monodesprotonada e didesprotonada, em que $\mathrm{pK}_{1}=1,6$ e $\mathrm{pK}_{2}=9,4$.

De modo geral, o pH do meio foi de extrema importância para o comportamento espectroscópico da CHL, CHL-T, HY e HY-G, visto que os espectros de absorção e emissão de fluorescência sofreram alterações significativas ao longo do $\mathrm{pH}$ estudado. No entanto, ressalta-se que em pH fisiológico, não foram observadas transições para os fotossensibilizadores estudados, o que caracteriza uma das propriedades de um fotossensibilizador ideal (11).

\subsection{Interação com surfactantes}

Visando-se investigar a interação dos surfactantes com esses microambientes micelares, foram realizados experimentos com CHL, CHL-T, HY e HY-G em tampão fosfato de sódio $2,0 \times 10^{-2} \mathrm{~mol} \mathrm{~L}^{-1}, \mathrm{pH} \mathrm{7,0}$ variando-se a concentração dos surfactantes iônicos CTAB e SDS e do surfactante não iônico Tween 20 no meio reacional até exceder sua concentração micelar crítica $(\mathrm{cmc})$.

A Figura 23 ilustra o comportamento espectral da CHL e CHL-T em função da concentração dos surfactantes CTAB e SDS. Na ausência de surfactante o espectro de absorção destes FS apresentou uma banda de Soret larga centrada em cerca de 390nm e quatro bandas Q centradas em 515, 547, 620 e 680nm condizentes com o modelo proposto para estes FS como sendo uma espécie neutra (item 5.6). Para ambos os fotossensibilizadores, a interação com os surfactantes iônicos se caracterizou analogamente em duas faixas distintas de concentração do surfactante: abaixo e acima da cmc.

Observou-se um aumento gradual na intensidade de absorção, bem como um deslocamento batocrômico da banda $\mathrm{Q}_{(0,0)}$ em função da concentração dos surfactantes abaixo da cmc. Em concentrações abaixo da cmc existem predominantemente monômeros de surfactante em solução. Considerando que estas clorinas são pouco solúveis em meio aquoso pode ocorrer uma interação entre o monômero do surfactante e o fotossensibilizador formando um aduto pré-micelar. Comparando-se a interação entre os fotossensibilizadores e os surfactantes para a formação destes adutos, verificouse que a interação com CTAB é facilitada, pois a formação de uma espécie pré-micelar 
ocorreu em uma concentração menor de surfactante $\left(2,00 \times 10^{-5} \mathrm{~mol} \mathrm{~L}^{-1}\right)$ do que na presença de $\operatorname{SDS}\left(2,00 \times 10^{-3} \mathrm{~mol} \mathrm{~L}^{-1}\right)$.

Figura 23- Espectros de absorção da CHL-T em função da concentração dos

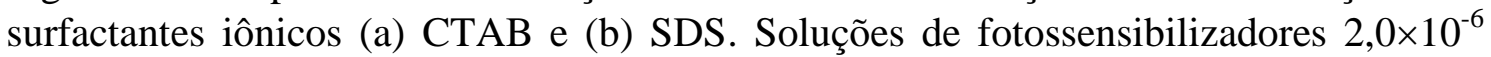
mol L ${ }^{-1}$ em tampão fosfato de sódio $2,0 \times 10^{-2} \mathrm{~mol} \mathrm{~L}^{-1}$ e $\mathrm{pH} 7,0$.

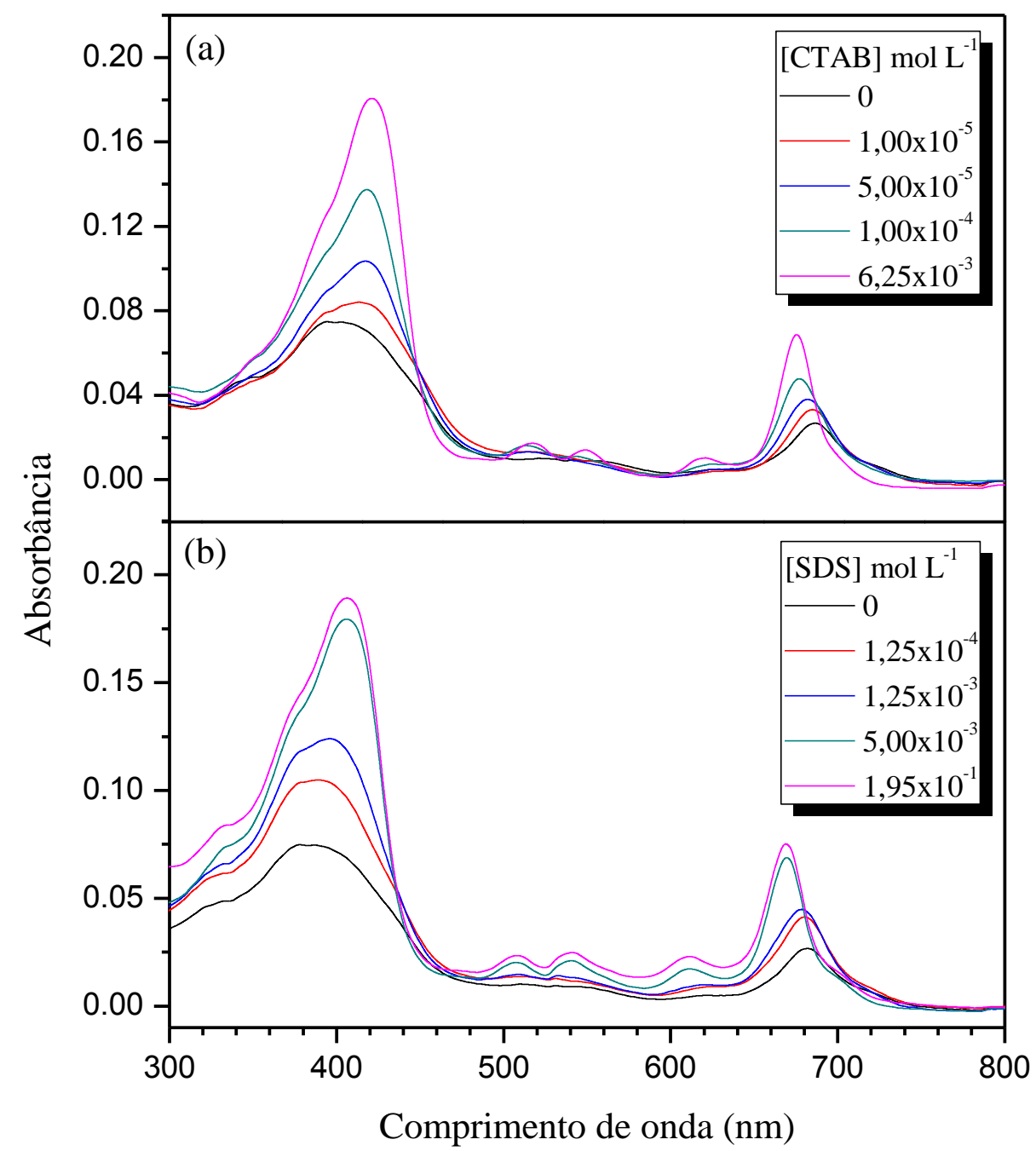

Posteriormente à formação do aduto pré-micelar, ocorreu um deslocamento hipsocrômico para as bandas Q, a intensidade de absorção prosseguiu com o aumento gradativo bem como se observou uma melhor definição de todas as bandas presentes nos espectros. As mudanças na banda de Soret foram menos pronunciadas quando comparadas às bandas $\mathrm{Q}$, todavia foi possível identificar um deslocamento batocrômico de 390 para $407 \mathrm{~nm}$, e um estreitamento desta banda, principalmente quando micelas de CTAB estavam presentes em solução. 
Sugere-se, portanto, que as interações entre CHL e CHL-T e os surfactantes iônicos em meio neutro ocorram através do equilíbrio duplo entre a forma agregada em meio aquoso, interação pré-micelar e a solubilização no microambiente micelar da seguinte forma:

$$
F S_{a g} \rightleftarrows A_{p m} \rightleftarrows F S_{m}
$$

onde $F S_{a g}$ é a forma agregada da CHL e CHL-T em meio aquoso, $A_{p m}$ é o aduto prémicelar e $F S_{m}$ é o monômero destes fotossensibilizadores solubilizados no microambiente micelar.

Gandini e colaboradores (149) também observaram a formação de adutos prémicelares dependentes do $\mathrm{pH}$ entre a porfirina aniônica base livre $\mathrm{TPPS}_{4}$ e o surfactante catiônico CTAC através de espectroscopia UV-Vis. A formação de adutos pré-micelares para Clorina p6 e os surfactantes CTAB e SDS foi descrita como sendo dependente do pH. Em concentrações de surfactantes acima da cmc esta interação é dependente da hidrofilicidade das espécies presentes em equilíbrio (150).

A interação entre os surfactantes iônicos e as hipericinas ocorreu de maneira distinta àquela observada para as clorinas. Na ausência de surfactante o espectro de absorção destes fotossensibilizadores apresentaram uma banda de maior intensidade centrada em $559 \mathrm{~nm}$ (agregado) e outra banda de menor intensidade em $596 \mathrm{~nm}$ (monômero), caracterizada anteriormente pela modelagem como espécie monoaniônica, como ilustrado na Figura 24.

Em função da concentração de SDS e CTAB, observou-se um deslocamento hipsocrômico bem como um aumento gradativo da intensidade de absorção. Com isso, todas as bandas presentes no espectro de absorção tornaram-se melhor definidas e a proporção de intensidade das bandas de absorção atribuídas à forma monomérica/agregada aumentou. Para as hipericinas o processo de formação de estruturas pré-micelares não foi detectado para ambos os surfactantes, uma vez que somente a forma solubilizada em microambiente foi identificada nos espectros de absorção deste fotossensibilizador. 
Figura 24-Espectros de absorção da HY-G em função da concentração dos surfactantes

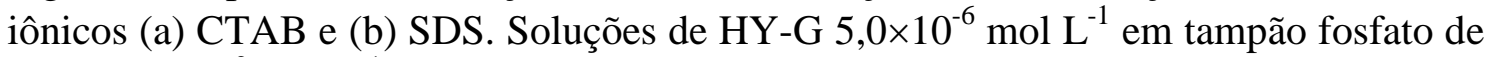
sódio $2,0 \times 10^{-2} \mathrm{~mol} \mathrm{~L}^{-1}$ e pH 7,0 .

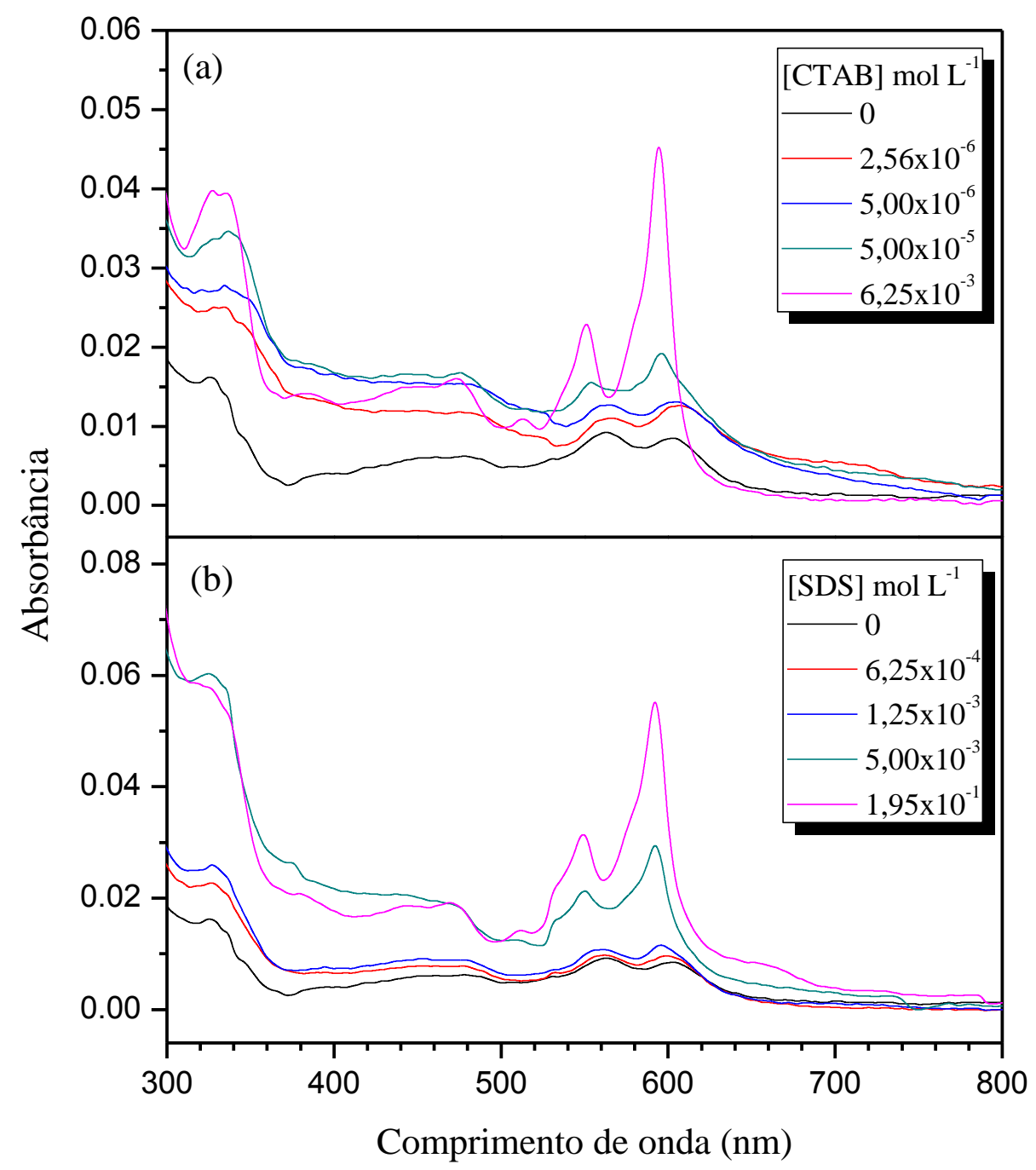

Gonçalves e colaboradores (151) estudaram através de espectroscopia o efeito da interação entre micelas de surfactantes iônicos na formação de agregados de metaloporfirinas iônicas. Os resultados mostraram que a interação entre a porfirina aniônica e micelas de CTAB induziu a formação de J-agregados. Este efeito não foi observado na interação entre esta porfirina e micelas de SDS. Os autores observaram ainda que essa interação afeta significativamente características fotofísicas como absorção, tempo de vida no estado tripleto e rendimento quântico de formação de oxigênio singleto para estas porfirinas.

A Figura 25 ilustra o comportamento espectral da CHL-T e HY em função da concentração do surfactante não iônico Tween 20. 
Figura 25-Espectros de absorção da (a) CHL-T e (b) HY-G em função da concentração do surfactante não iônico Tween 20. Soluções de fotossensibilizadores $2,0 \times 10^{-6} \mathrm{~mol} \mathrm{~L}-1$ em tampão fosfato de sódio $2,0 \times 10^{-2} \mathrm{~mol} \mathrm{L-1} \mathrm{e} \mathrm{pH} \mathrm{7,0.}$

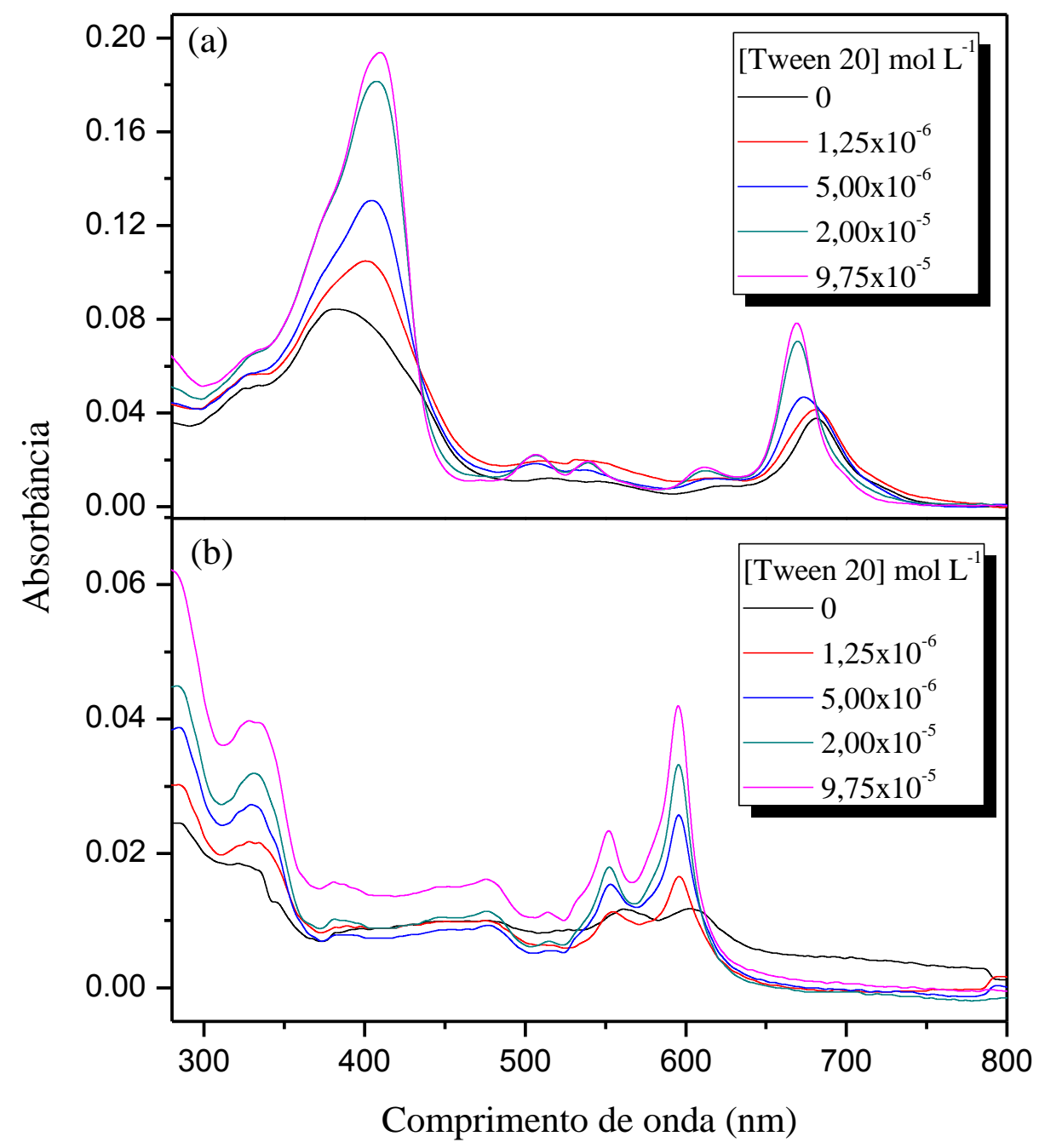

Em função da concentração de Tween 20, todos os fotossensibilizadores apresentaram um deslocamento hipsocrômico e aumento gradativo da intensidade de absorção. Como observado para o processo de solubilização das hipericinas em surfactantes iônicos, todas as bandas presentes no espectro de absorção tornaram-se melhor definidas, caracterizando assim, a completa solubilização destes compostos pelas micelas de Tween 20. Além disso, não foi constatado o processo de formação de estruturas pré-micelares para nenhum dos surfactantes estudados, uma vez que somente a forma solubilizada em microambiente foi identificada nos espectros de absorção destes fotossensibilizadores. 
O perfil dos espectros de absorção de CHL,CHL-T, HY e HY-G solubilizados em microambiente micelar de CTAB, SDS e Tween 20 foi semelhante ao perfil espectral destes fotossensibilizadores solubilizados em DMSO. Todas as considerações atribuídas à formação de adutos micelares e/ou fotossensibilizador solubilizados em microambientes micelares foram caracterizados ainda por espectrometria de fluorescência. Isto corroborou com a interpretação de que a espécie de fotossensibilizador presente em $\mathrm{pH}$ 7,0 é a forma agregada.

\subsection{Fotobranqueamento}

O fotobranqueamento dos fotossensibilizadores foi estudado através de espectroscopia de absorção e de emissão de fluorescência utilizando-se arranjos matriciais de LED como fontes de irradiação. Devido à banda $\mathrm{Q}_{\mathrm{x}}(0,0)$ de CHL e CHL$\mathrm{T}$ estarem posicionadas em torno de $660 \mathrm{~nm}$, estes compostos foram irradiados com LED vermelho (emissão centrada em $660 \pm 10 \mathrm{~nm}$ ) enquanto que as amostras de HY e

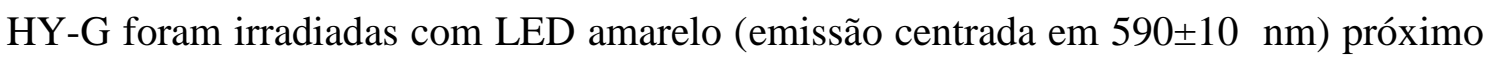
a banda de absorção em torno de $600 \mathrm{~nm}$ do grupo cromóforo comum às naftodiantronas (vide item 5.1). Os espectros de absorção e de fluorescência dos fotossensibilizadores solubilizados em DMSO em função do tempo de irradiação com LED de comprimento de onda adequado estão ilustrados na Figura 26.

Todos os fotossensibilizadores estudados apresentaram essencialmente $\mathrm{o}$ fenômeno de fotobranqueamento. Observou-se unicamente a diminuição da absorbância destes compostos em função do tempo de irradiação sem o surgimento de novas bandas (Figura 26(a) e (c)) que indicariam a formação de fotoprodutos comumente encontrados na fotodecomposição de clorinas $(11,107,126)$. Os resultados experimentais obtidos por espectroscopia de emissão de fluorescência para os fotossensibilizadores solubilizados em DMSO corroboraram com essa interpretação (Figura 26(b) e (d)).

Figura 26: Espectros de absorção e fluorescência dos FS $1,5 \times 10^{-6} \mathrm{~mol} \mathrm{~L}^{-1}$ em DMSO irradiados por até $3600 \mathrm{~s}$. (a) e (b) CHL-T empregando LED vermelho $660 \pm 10 \mathrm{~nm}$ com 
irradiância de $26,7 \mathrm{~mW} \mathrm{~cm}^{-2}$ e (c) e (d) HY-G empregando LED amarelo 590 $\pm 10 \mathrm{~nm}$ irradiância de $15,8 \mathrm{~mW} \mathrm{~cm}^{-2}$.
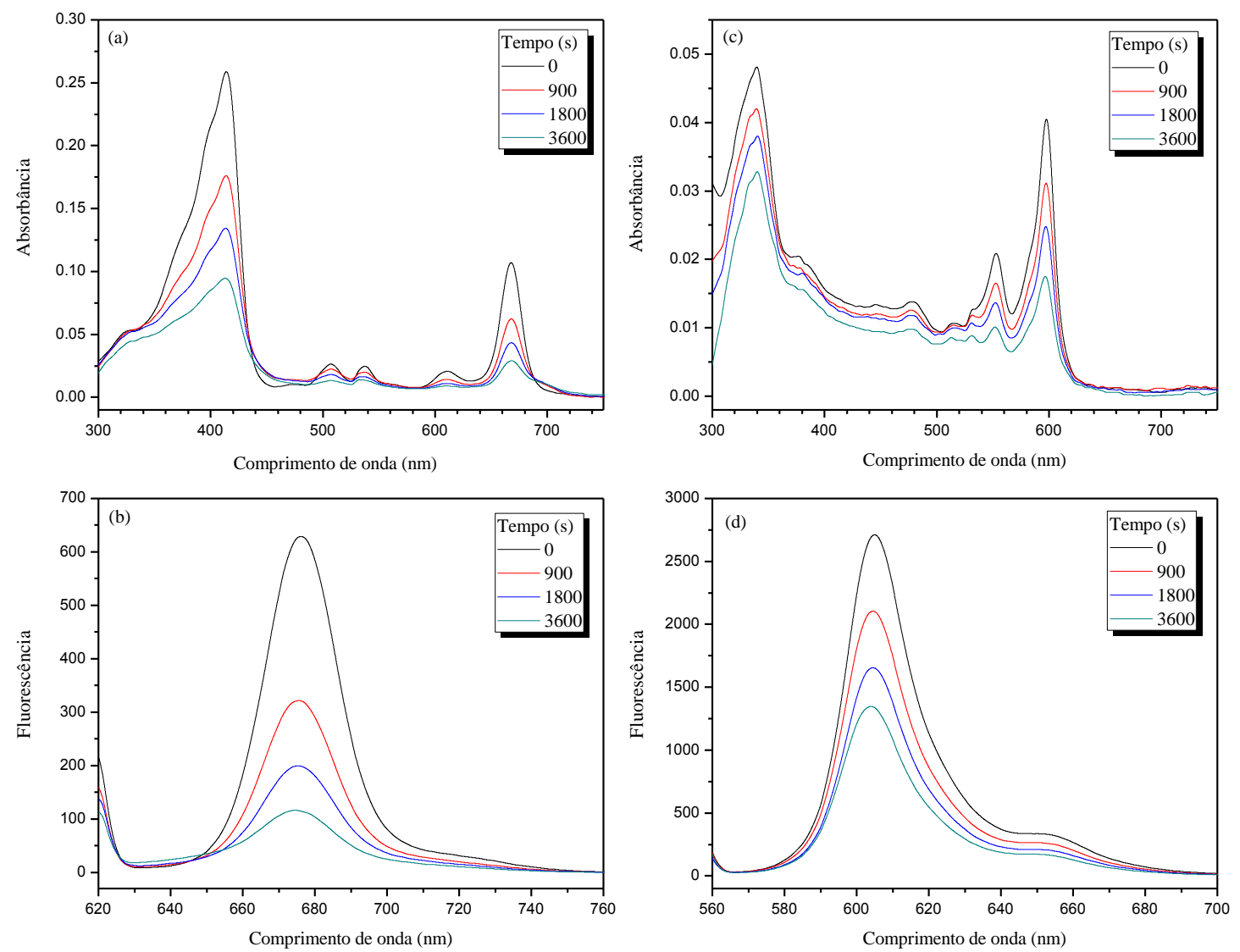

A Figura 27 apresenta a porcentagem de fotossensibilizador remanescente em solução em função do tempo em DMSO e em meio aquoso. Considerando-se o tempo limite de 60 minutos, observou-se que o fotobranqueamento em solução de DMSO foi de $61 \pm 7,81 \pm 9,51 \pm 6$ e 50 $\pm 8 \%$ para CHL, CHL-T, HY e HY-G, respectivamente (Figura 27 (a)). Em meio aquoso, este processo também foi observado, porém após 60 minutos de irradiação o fotobranqueamento em solução foi de apenas $29 \pm 9,40 \pm 15,3 \pm 1$ e $0 \%$ para CHL, CHL-T, HY e HY-G, respectivamente (Figura 27(b)). 
Figura 27: Porcentagem dos fotossensibilizadores remanescentes em solução após a irradiação com LED de comprimento de onda adequado em função do tempo em (a) DMSO e (b) tampão fosfato de sódio $2,0 \times 10^{-2} \mathrm{~mol} \mathrm{~L}^{-1} \mathrm{pH} 7,0$.

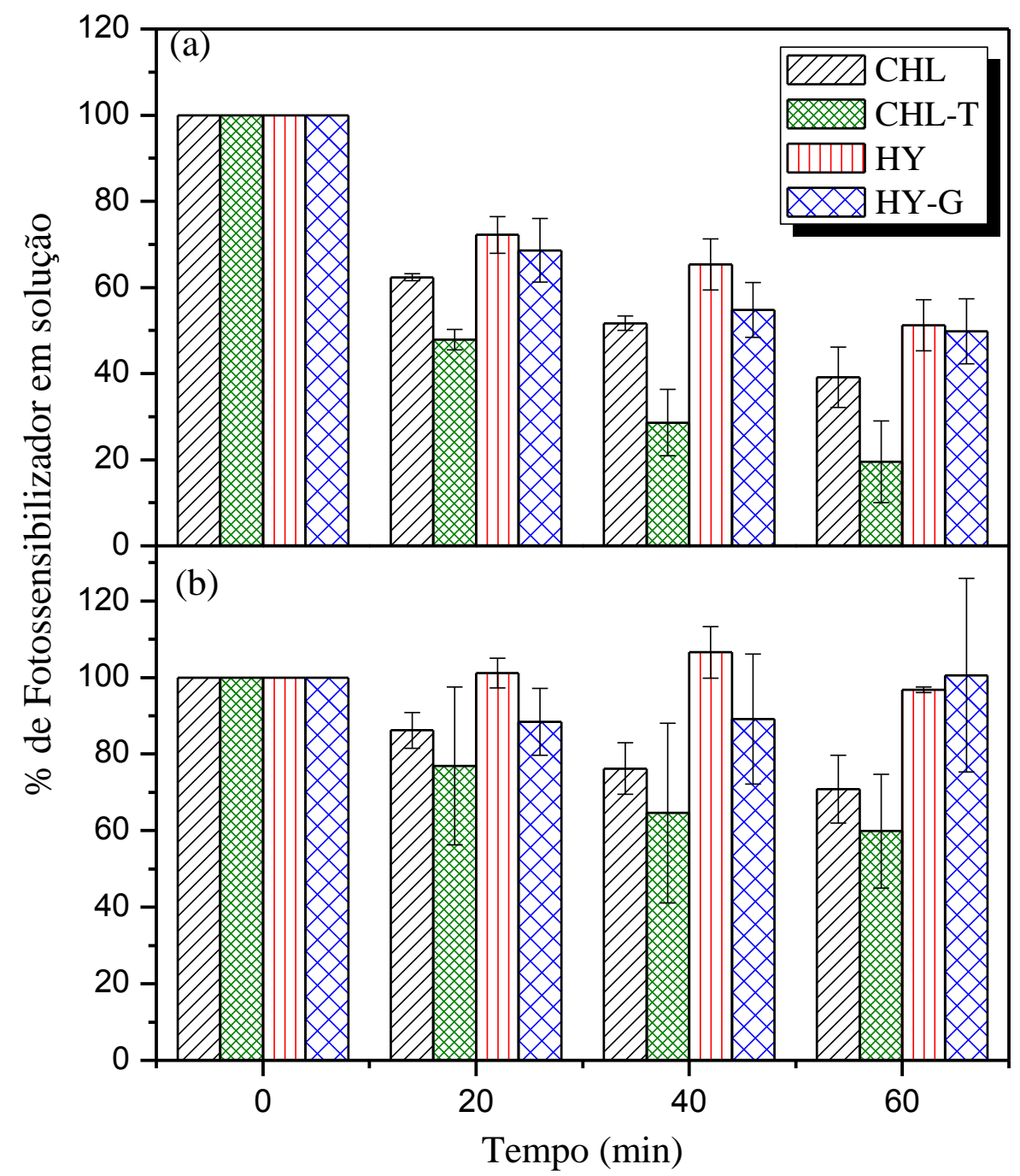

Essa redução nas taxas de fotobranqueamento em meio aquoso é explicada pelo estado e forma de agregação dos fotossensibilizadores. Em estudos realizados em porfirinas $(74,75,152,153)$, o rendimento quântico de formação do oxigênio singleto foi diminuído quando houve a formação do agregado do tipo $\mathrm{H}$ (empilhamento face a face) $(74,75)$. Os autores argumentam que a formação do agregado tipo $\mathrm{J}$ (cabeçacauda) não afetaria o rendimento quântico de formação de oxigênio singleto.

Ferreira e colaboradores estudaram a fotoestabilidade de três clorinas comerciais por emissão de fluorescência e observaram que a ordem de susceptibilidade durante a irradiação em solução aquosa foi Radachlorin ${ }^{\circledR}<$ Photoditazine $<$ Foscan ${ }^{\circledR}$. Os autores 
justificaram o menor fotobranqueamento do Foscan ${ }^{\circledR}$ devido à presença de J-agregados em solução que inibem o processo foto-oxidativo deste composto (126).

Tem sido descrito que a degradação do fotossensibilizador sob a influência da luz obedece à cinética química de pseudo-primeira ordem $(11,126)$. A lei de velocidade que descreve o fotobranqueamento dos fotossensibilizadores pode ser expressa por:

$$
\frac{d[C]}{d t}=-k[C]
$$

onde $[C], k$ e $t$ são a concentração do fotossensibilizador, a constante de fotobranqueamento e o tempo, respectivamente.

Como as representações gráficas da variação do logaritmo natural (base e) das absorbâncias apresentaram um decréscimo linear com o tempo de irradiação, os dados foram ajustados empregando-se modelos cinéticos de pseudo-primeira ordem determinando-se as respectivas constantes de velocidade de fotobranqueamento, $\mathrm{k}_{\mathrm{fb}}$, $\left(\min ^{-1}\right)$, para cada um dos fotossensibilizadores em diferentes solventes (Tabela 10).

Tabela 10- Valores de constante de fotobranqueamento para os fotossensibilizadores em DMSO e meio aquoso.

\begin{tabular}{cccc}
\hline Fotossensibilizador & $\mathrm{k}_{\mathrm{fb}}$ & $\mathrm{k}_{\mathrm{fdf}}$ & $\mathrm{k}_{\mathrm{fb}}^{\prime}$ \\
\hline CHL & $1,44 \pm 0,08(0,95)$ & $1,90 \pm 0,14(0,96)$ & $0,66 \pm 0,02(0,99)$ \\
CHL-T & $2,84 \pm 0,13(0,97)$ & $3,19 \pm 0,15(0,98)$ & $1,14 \pm 0,04(0,98)$ \\
HY & $1,15 \pm 0,14(0,86)$ & $1,07 \pm 0,01(0,99)$ & - \\
HY-G & $1,35 \pm 0,12(0,92)$ & $1,59 \pm 0,03(0,99)$ & -
\end{tabular}

onde $\mathrm{k}_{\mathrm{bd}}$ e $\mathrm{k}_{\mathrm{fbf}}$ são a constante de fotobranqueamento do fotossensibilizador em DMSO obtido por UV-Vis e emissão de fluorescência, respectivamente e $\mathrm{k}_{\mathrm{fb}}^{\prime}$ é a constante de fotobranqueamento do fotossensibilizador em meio aquoso obtido por UV-Vis. As unidades de todas as constantes são expressas em $10^{-2} \mathrm{~min}^{-1} \mathrm{e}$ os valores entre parênteses indicam o $\mathrm{r}^{2}$ do ajuste linear da curva.

Observou-se que enquanto os valores de $\mathrm{k}_{\mathrm{fbf}}$ para as clorinas foram ligeiramente superiores quando comparados aos valores de $\mathrm{k}_{\mathrm{fb}}$, as hipericinas não apresentaram diferenças significativas entre estas constantes. Além disso, para todos os fotossensibilizadores, empregando-se a emissão de fluorescência as dispersões de 
resíduos para o modelo matemático empregado foram inferiores, indicando que esta é a técnica mais sensível para a detecção do fotobranqueamento destes compostos.

Os valores de $\mathrm{k}_{\mathrm{fb}}$ e $\mathrm{k}_{\mathrm{fbd}}$ da CHL-T foram superiores aos valores da CHL, corroborando com cálculos previamente descritos que indicavam uma diferença de cerca de $20 \%$ a mais de CHL em solução de DMSO nas mesmas condições de irradiação da CHL-T. Não foram encontradas diferenças significativas entres estas constantes para HY e HY-G, corroborando com o valor de $50 \%$ de fotossensibilizador em solução de DMSO posteriormente à irradiação que ambas apresentaram anteriormente.

Os valores de $\mathrm{k}_{\mathrm{fb}}$ para as clorinas foram inferiores aos valores das demais constantes, corroborando com a hipótese de um processo de fotobranqueamento com menor velocidade em meio aquoso caracterizando pela agregação destes compostos. Outro fator que se deve considerar é a solubilidade maior do oxigênio em DMSO (154). Não foi possível determinar os valores de k' ${ }_{\text {fb }}$ para as hipericinas, uma vez que não se observou o processo de fotobranqueamento destes compostos em meio aquoso.

\subsection{Determinação da formação de oxigênio singleto pelo método estacionário}

Dentre os diversos métodos que são empregados para a detecção e quantificação de oxigênio singleto $\left({ }^{1} \mathrm{O}_{2}\right)$, o método estacionário destaca-se por sua sensibilidade, praticidade e baixo custo. Neste método, a geração de ${ }^{1} \mathrm{O}_{2}$ pode ser quantificada por meio da oxidação de substratos específicos que atuam como sequestradores químicos. Com o intuito de se comparar diversas metodologias, neste trabalho, a geração de ${ }^{1} \mathrm{O}_{2}$ proveniente dos fotossensibilizadores excitados foi mensurada utilizando-se três diferentes sequestradores químicos: o ácido úrico (AU), o p-nitroso dimetilanilina (RNO) e o 1,3-difenilisobenzofurano (DPBF).

Considerando-se a baixa solubilidade dos fotossensibilizadores empregados neste estudo, para realizar a quantificação de geração de ${ }^{1} \mathrm{O}_{2}$ em função da concentração destes fotossensibilizadores, adicionou-se à solução o surfactante não iônico Tween 20 em concentração inferior a sua cmc. Para a escolha das concentrações dos fotossensibilizadores a serem empregadas nesta quantificação confrontou-se a emissão de fluorescência em $\lambda$ fixo em função da concentração dos fotossensibilizadores (Figura 28). 
Figura 28- Intensidade de fluorescência em $\lambda$ fixo em função da concentração de (a) CHL e CHL-T e (b) HY e HY-G em tampão fosfato de sódio $2,0 \times 10^{-2} \mathrm{~mol} \mathrm{~L}^{-1}$ acrescido de $0,001 \%$ de Tween 20 ( $\lambda_{\text {ex }}=610 \mathrm{~nm}$ para CHL e CHL-T e $545 \mathrm{~nm}$ para HY e HY-G).

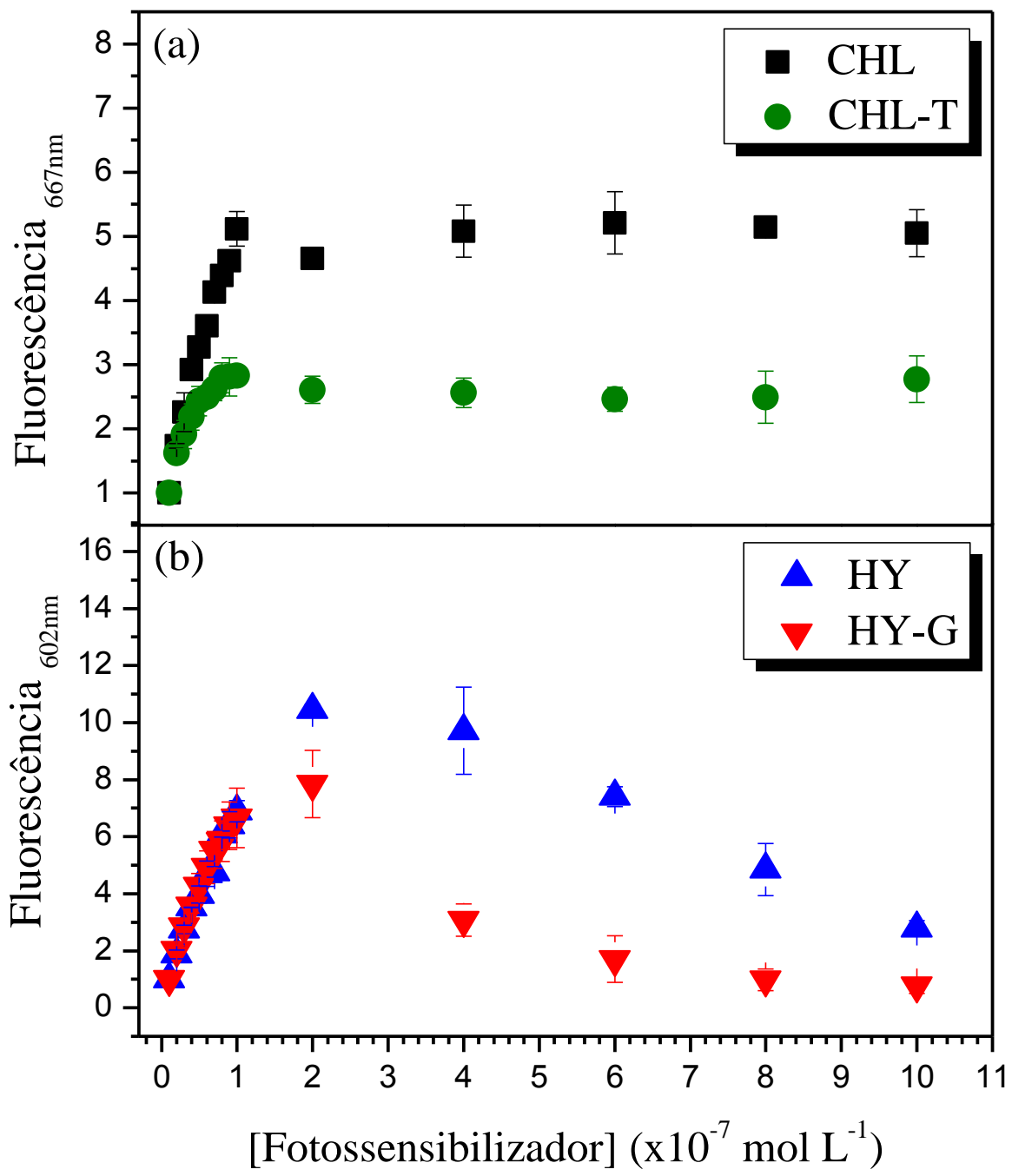

Observou-se o aumento da intensidade de fluorescência dos fotossensibilizadores em função da concentração até cerca de $1 \times 10^{-7} \mathrm{~mol} \mathrm{~L}^{-1}$. Sugere-se que exista a formação estequiométrica de um aduto pré-micelar entre Tween 20 e fotossensibilizador. Acima desta concentração não existe surfactante suficiente para solubilizar o fotossensibilizador e inicia-se o processo de agregação. Portanto a solubilidade do fotossensibilizador foi limitada pela quantidade de surfactante disponível para sua solubilização, fato que será determinante para a quantificação de ${ }^{1} \mathrm{O}_{2}$. 
5.9.1 Avaliação da atividade fotodinâmica dos fotossensibilizadores

Visando-se quantificar indiretamente a produção de ${ }^{1} \mathrm{O}_{2}$, os valores de atividade fotodinâmica (AF) foram determinados em função da concentração dos fotossensibilizadores. Foram obtidos espectros de absorção de soluções destes compostos em diferentes concentrações na presença de excesso de ácido úrico (AU) em solução tampão fosfato de sódio $2,0 \times 10^{-2} \mathrm{~mol} \mathrm{~L}^{-1}$ acrescido de Tween $200,001 \%$. As soluções de CHL e CHL-T foram irradiadas em $660 \mathrm{~nm}$ e as de HY e HY-G em $590 \mathrm{~nm}$ em função do tempo.

$\mathrm{O}$ AU em meio aquoso apresenta exclusivamente duas bandas de absorção em 235 e 291 nm (Figura 29) que não interferem nas excitações dos fotossensibilizadores quando irradiados. Além disso, a absorção dos fotossensibilizadores na região espectral entre 190 e 330 nm é desprezível.

Figura 29- Espectro de absorção do ácido úrico $1,20 \times 10^{-4} \mathrm{~mol} \mathrm{~L}^{-1}$ em solução em tampão fosfato de sódio $2,0 \times 10^{-2} \mathrm{~mol} \mathrm{~L}^{-1} \mathrm{pH} 7,0$ acrescido de $0,001 \%$ de Tween 20 .

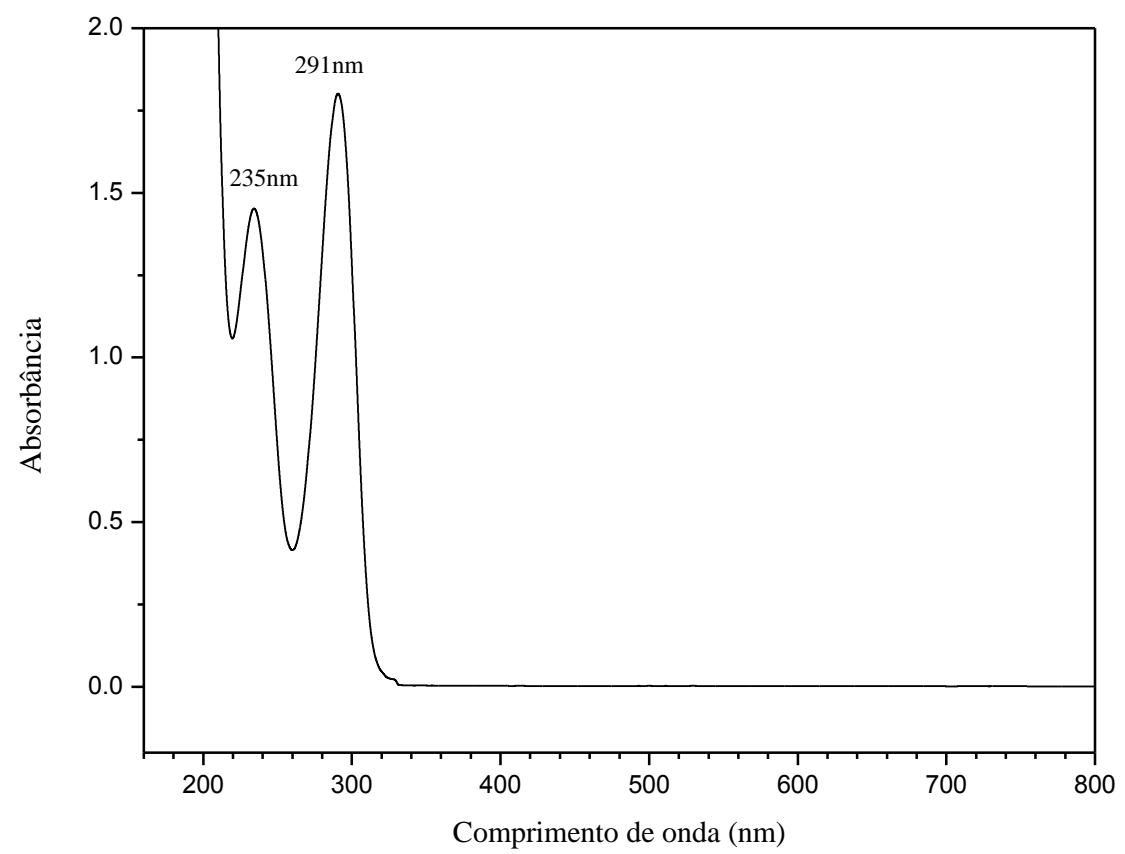

Não foram observadas mudanças espectrais nas soluções contendo AU e/ou AU+fotossensibilizador na ausência de irradiação. Contudo, quando a mistura contendo o fotossensibilizador é irradiada, ${ }^{1} \mathrm{O}_{2}$ é gerado na solução, sendo sequestrado pelo $\mathrm{AU}$ acarretando sua foto-oxidação com cinética de pseudo-primeira ordem. A Figura 30 
apresenta um exemplo deste decaimento causado pelo ${ }^{1} \mathrm{O}_{2}$ proveniente da CHL-T irradiada em $660 \mathrm{~nm}$.

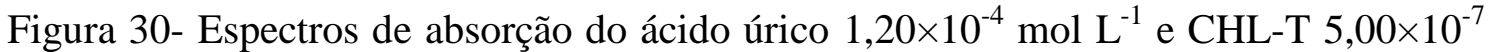
mol L $\mathrm{L}^{-1}$ em função do tempo de irradiação. Solução em tampão fosfato de sódio $2,0 \times 10^{-}$ ${ }^{2} \mathrm{~mol} \mathrm{~L}^{-1} \mathrm{pH}$ 7,0 contendo 0,001\% de Tween 20, irradiado com LED $660 \mathrm{~nm}, \mathrm{I}=27,6$ $\mathrm{mW} \mathrm{cm}{ }^{-2}$.

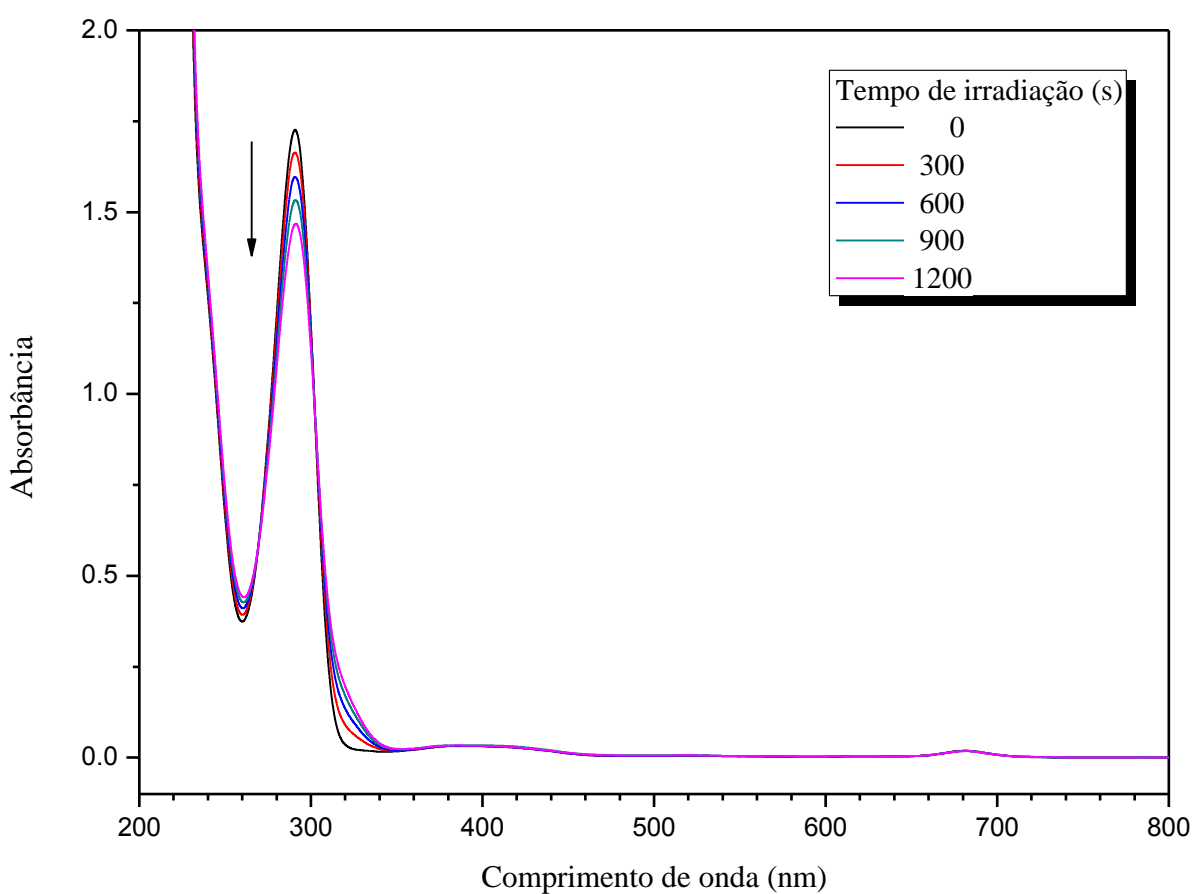

O decréscimo da banda de absorção do AU centrada em $291 \mathrm{~nm}$ foi observado em função do tempo de irradiação para todos os fotossensibilizadores. A decomposição do AU foi decorrente da captura do ${ }^{1} \mathrm{O}_{2}$ gerado pelos fotossensibilizadores no estado tripleto e o oxigênio molecular. Ao longo da irradiação obteve-se uma correlação linear entre o logaritmo da variação da absorbância do AU e a concentração do fotossensibilizador. Desta forma, utilizou-se o tempo fixo de irradiação de $300 \mathrm{~s}$ (7) para avaliar a eficiência fotodinâmica (Equação 4) dos fotossensibilizadores em função de sua concentração. 
Figura 31- Valores de AF em função da concentração de (a) CHL e CHL-T e (b) HY e HY-G. AF $\left(\mathrm{m}^{2} \mathrm{~J}^{-1}\right)$ calculados através da Equação $4(\Delta \mathrm{t}=300 \mathrm{~s})$.

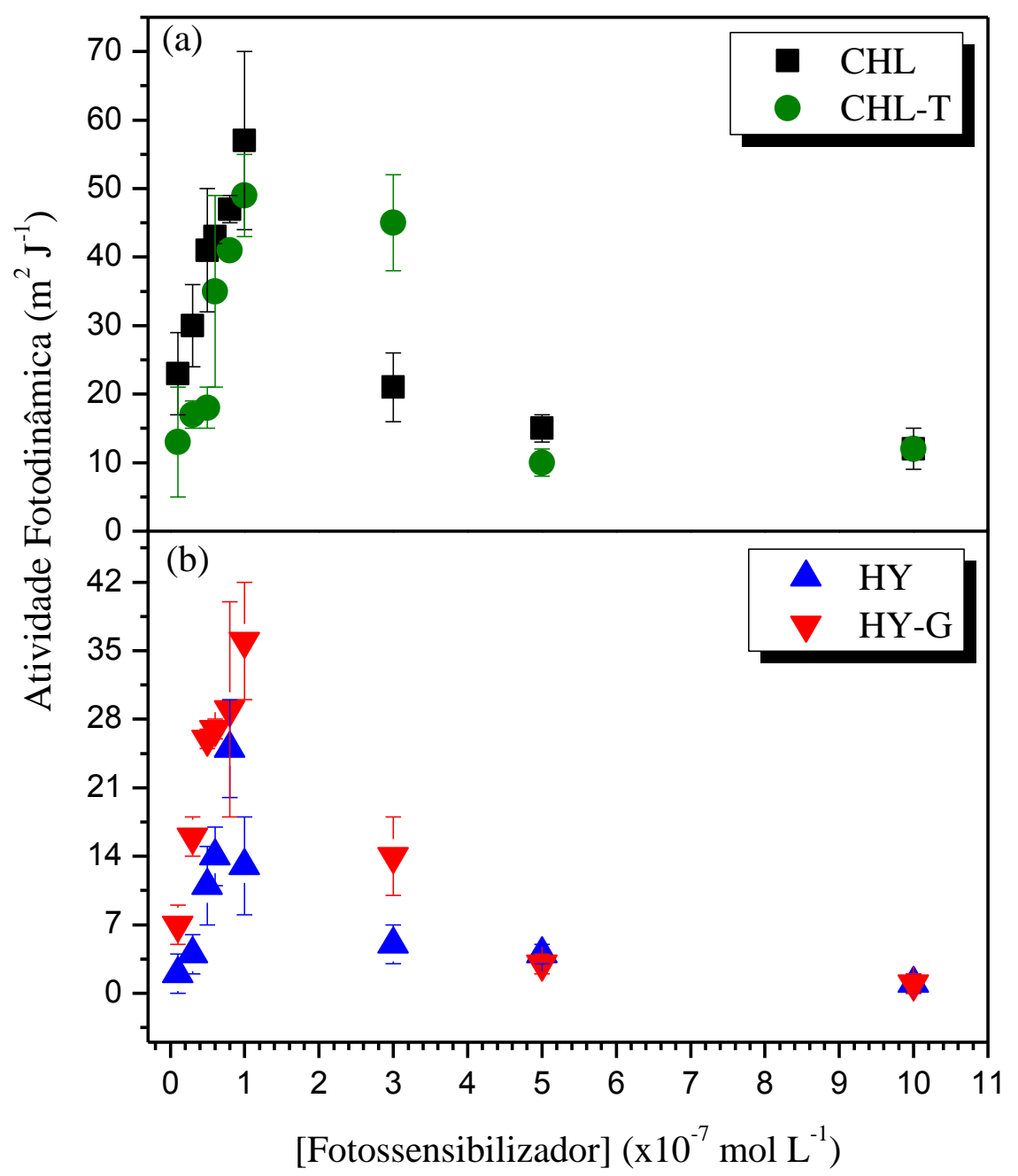

O perfil da curva ilustrado na Figura 31 mostrou que para todos os fotossensibilizadores houve um aumento da AF em função da concentração até cerca de $1,00 \times 10^{-7} \mathrm{~mol} \mathrm{~L}^{-1}$. Para concentrações maiores houve um decréscimo nos valores de AF provavelmente causado pela baixa solubilidade dos fotossensibilizadores que não se encontram na forma de aduto pré-micelar, como discutido na Figura 28.

A constante de formação de ${ }^{1} \mathrm{O}_{2}, \alpha_{\mathrm{AF}}$, foi determinado através do coeficiente angular da correlação entre a atividade fotodinâmica em função da concentração do fotossensibilizador (Tabela 11). Observou-se que CHL, HY e HY-G não apresentaram diferenças significativas (teste t de Student não pareado com desvios padrão que não diferem estatisticamente), porém quando comparados com CHL-T foram ligeiramente inferiores. 
Tabela 11- Valores de constante de velocidade de atividade fotodinâmica para os fotossensibilizadores.

\begin{tabular}{cc}
\hline Fotossensibilizador & $\alpha_{\mathrm{AF}}\left(\times 10^{8}\right)$ \\
\hline CHL & $3,68 \pm 0,27$ \\
CHL-T & $4,31 \pm 0,71$ \\
HY & $3,27 \pm 0,51$ \\
HY-G & $3,06 \pm 0,40$
\end{tabular}

onde $\alpha_{\mathrm{AF}}$ é a constante de formação de ${ }^{1} \mathrm{O}_{2}$ para os fotossensibilizadores referente à atividade fotodinâmica (AU).

Além do AU, empregou-se ainda o RNO que é outro captador de ${ }^{1} \mathrm{O}_{2}$ como dosímetro químico em meio aquoso para a determinação da potencialidade dos fotossensibilizadores $(8,13,88)$. As análises foram realizadas nas mesmas condições experimentais anteriormente citadas para o AU.

O método do RNO consiste na supressão indireta deste sequestrador químico pelo ${ }^{1} \mathrm{O}_{2}$ quando há um substrato em solução. $\mathrm{O}{ }^{1} \mathrm{O}_{2}$ é capturado pela L-Histidina que atua como substrato, e como subproduto forma-se um composto oxidado que por sua vez é capaz de foto-oxidar o RNO. O mecanismo desta reação pode ser descrito como:

$$
\begin{array}{cc}
{ }^{1} \mathrm{O}_{2}+\mathrm{S} \rightarrow \mathrm{SO}_{2} & \text { Equação } 15 \\
\mathrm{SO}_{2}+\mathrm{RNO} \rightarrow \cdot \mathrm{RNO}+\text { produtos } & \text { Equação } 16
\end{array}
$$

onde $S$ é o substrato (L-Histidina) e $\cdot R N O$ é o RNO foto-oxidado.

Assim como o AU, o RNO em meio aquoso apresenta uma banda de absorção em 440 nm que não interfere nas excitações das clorinas quando irradiadas em $660 \mathrm{~nm}$ e as hipericinas em $590 \mathrm{~nm}$ (Figura 32). 


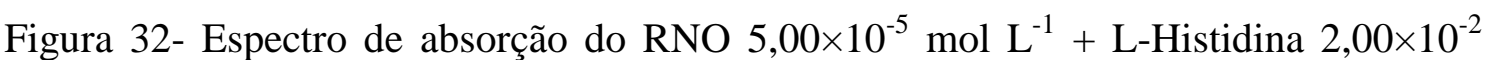
mol L $\mathrm{L}^{-1}$ em solução de tampão fosfato de sódio $2,0 \times 10^{-2} \mathrm{~mol} \mathrm{~L}^{-1} \mathrm{pH} \mathrm{7,0}$ acrescido de $0,001 \%$ de Tween 20 .

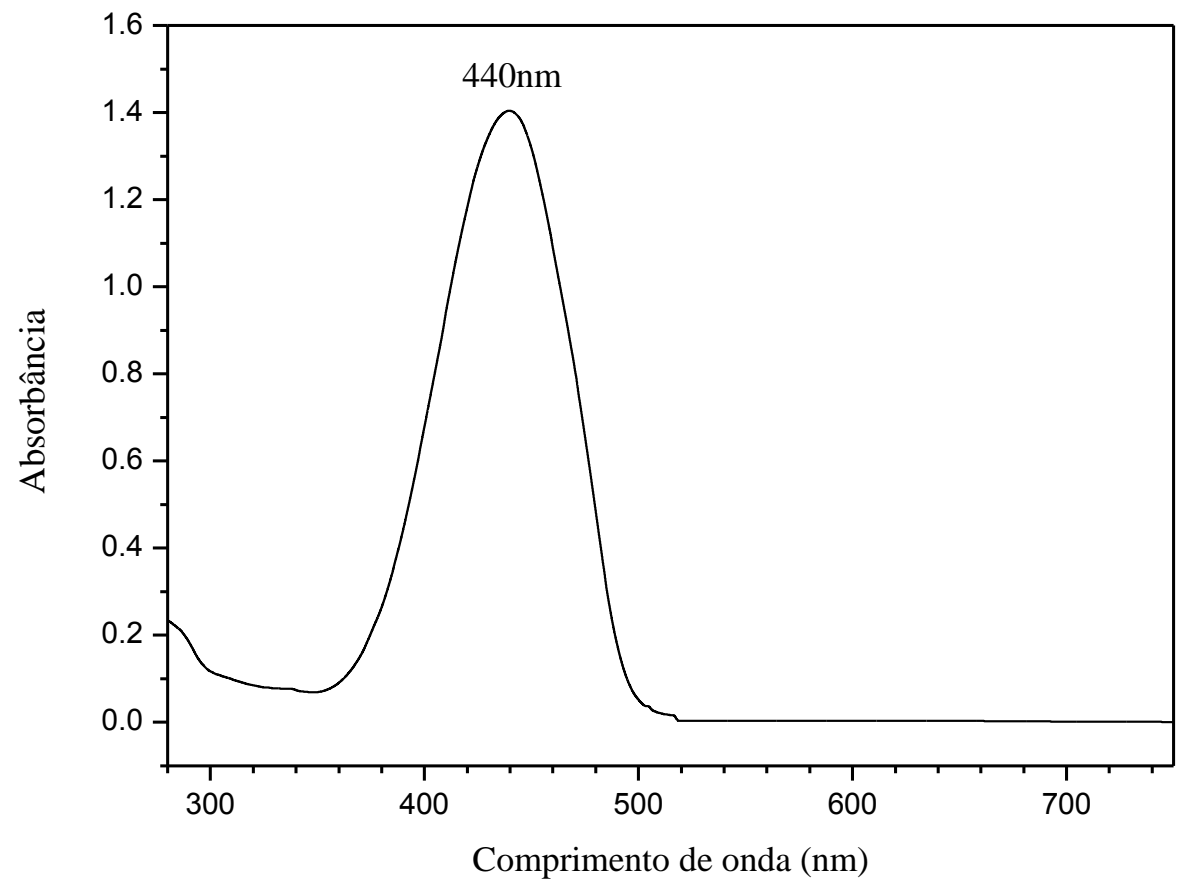

Analogamente ao ocorrido nos experimentos utilizando AU como captador, o decréscimo da banda de absorção do RNO foi observado após a irradiação das soluções contendo RNO, L-Histidina e os fotossensibilizadores, segundo o mecanismo de degradação descrito acima. Esta reação seguiu cinética de ordem zero na faixa de concentração mensurável, ou seja, a densidade ótica do RNO apresentou correlação linear em função do tempo. O coeficiente de correlação desta regressão linear foi definido como constante de velocidade de degradação do RNO $\left(k_{\mathrm{RNO}}\right)$, calculado para cada uma das concentrações empregadas neste estudo.

A determinação da constante de formação de ${ }^{1} \mathrm{O}_{2}$, utilizando-se o método do RNO foi baseada na correlação entre $k_{R N O}$ em função da concentração do fotossensibilizador (Figura 33). 
Figura 33- Valores da constante de velocidade de decomposição do RNO em função da concentração dos fotossensibilizadores.

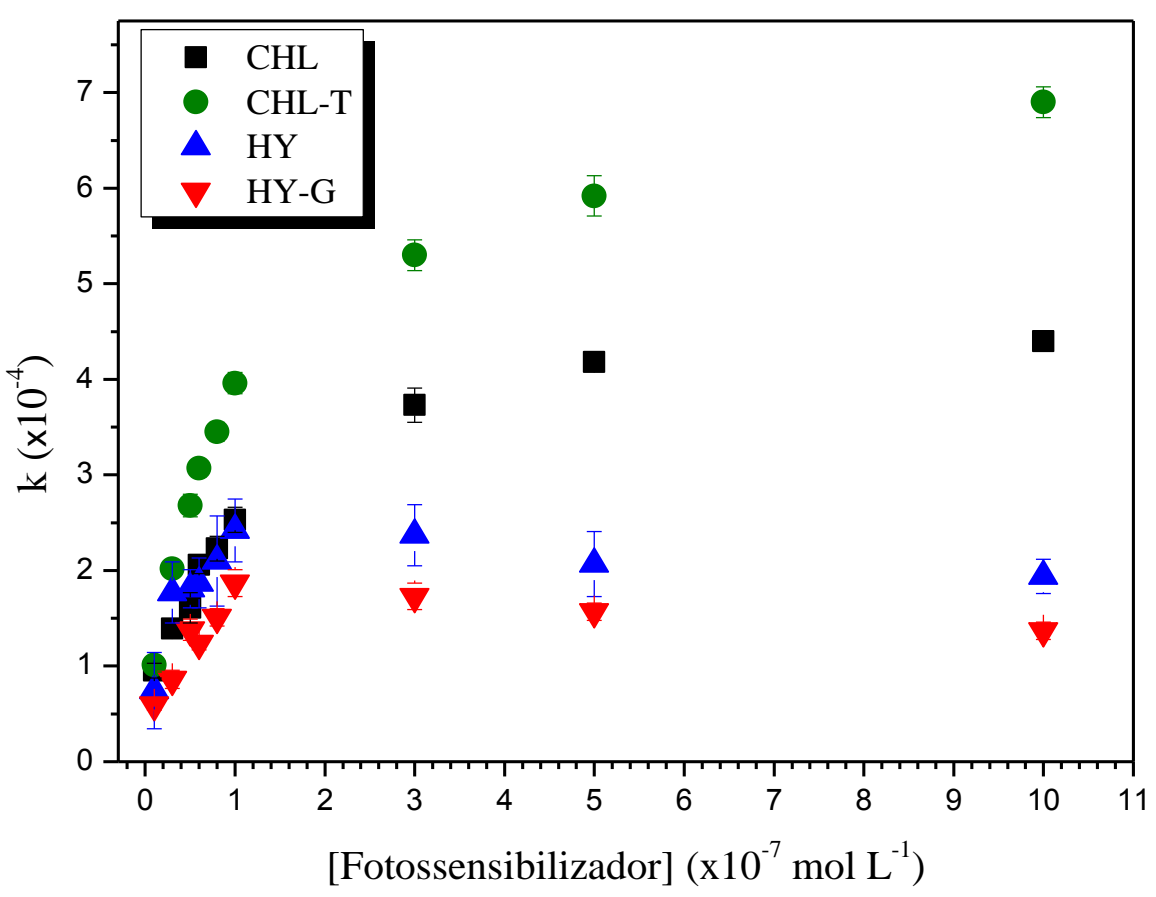

O perfil da curva mostrou que para todos os compostos houve um aumento de $\mathrm{k}_{\mathrm{RNO}}$ em função da concentração até cerca de $1,00 \times 10^{-7} \mathrm{~mol} \mathrm{~L}{ }^{-1}$. Posteriormente a esta concentração houve uma interrupção da linearidade causada pela baixa solubilidade dos fotossensibilizadores que não se encontram na forma de aduto pré-micelar. Além disto, similarmente ao observado em experimentos anteriores, CHL, HY e HY-G não apresentam diferenças estatísticas na geração de espécies citotóxicas, enquanto que a CHL-T mostrou-se ao menos 1,8 vezes mais eficiente que os demais fotossensibilizadores (coeficiente angular do $k_{\mathrm{RNO}} \mathrm{em}$ função da concentração do fotossensibilizador, $\alpha_{\mathrm{RNO}}$; Tabela 12 ).

Tabela 12- Valores de constante de velocidade de formação de oxigênio singleto para os fotossensibilizadores.

\begin{tabular}{cc}
\hline Fotossensibilizador & $\alpha_{\text {RNO }}\left(\times 10^{3}\right)$ \\
\hline CHL & $1,71 \pm 0,15$ \\
CHL-T & $3,19 \pm 0,29$ \\
HY & $1,57 \pm 0,36$ \\
HY-G & $1,36 \pm 0,16$
\end{tabular}

onde $\alpha_{\text {RNO }}$ é a a constante de formação de ${ }^{1} \mathrm{O}_{2}$ para os fotossensibilizadores referente ao RNO. 
Estes resultados corroboram com experimentos prévios (emissão de fluorescência e atividade fotodinâmica) em que se demonstrou que a agregação destes fotossensibilizadores ocorre nestas condições em concentrações superiores a $1,00 \times 10^{-7}$ mol L ${ }^{-1}$.

Tem sido descrito que a agregação do fotossensibilizador é uma das causas da diminuição do rendimento quântico de formação de ${ }^{1} \mathrm{O}_{2}(66,155-157)$. Outro estudo envolvendo hipericina e um derivado obtido por encapsulamento em partículas peptídicas funcionalizadas mostrou que o derivado apresentou uma atividade fotodinâmica cerca de $57 \%$ maior que o composto original devido à menor agregação em meio aquoso (90).

5.9.2 Determinação do rendimento quântico de geração de oxigênio singleto por DPBF

A reação entre o DPBF e o ${ }^{1} \mathrm{O}_{2}$ pode ser monitorada espectroscopicamente através da formação de um endoperóxido que não possui absorção na região do visível. O DPBF apresenta uma banda de absorção em $411 \mathrm{~nm}$ que diminui em função do tempo, caracterizando a sua degradação proveniente da reação com o ${ }^{1} \mathrm{O}_{2}$ produzido pelo fotossensibilizador excitado (158). Na região do espectro eletromagnético em que os fotossensibilizadores foram excitados (clorinas em $660 \mathrm{~nm}$ e hipericinas em $590 \mathrm{~nm}$ ), este sequestrador químico não apresenta bandas de absorção, portanto, assegura-se que a degradação do DPBF ocorreu essencialmente pela fotodinamização destes compostos (Figura 34). 
Figura 34- Espectros de absorção do DPBF $5,00 \times 10^{-5} \mathrm{~mol} \mathrm{~L}^{-1}$ em etanol.

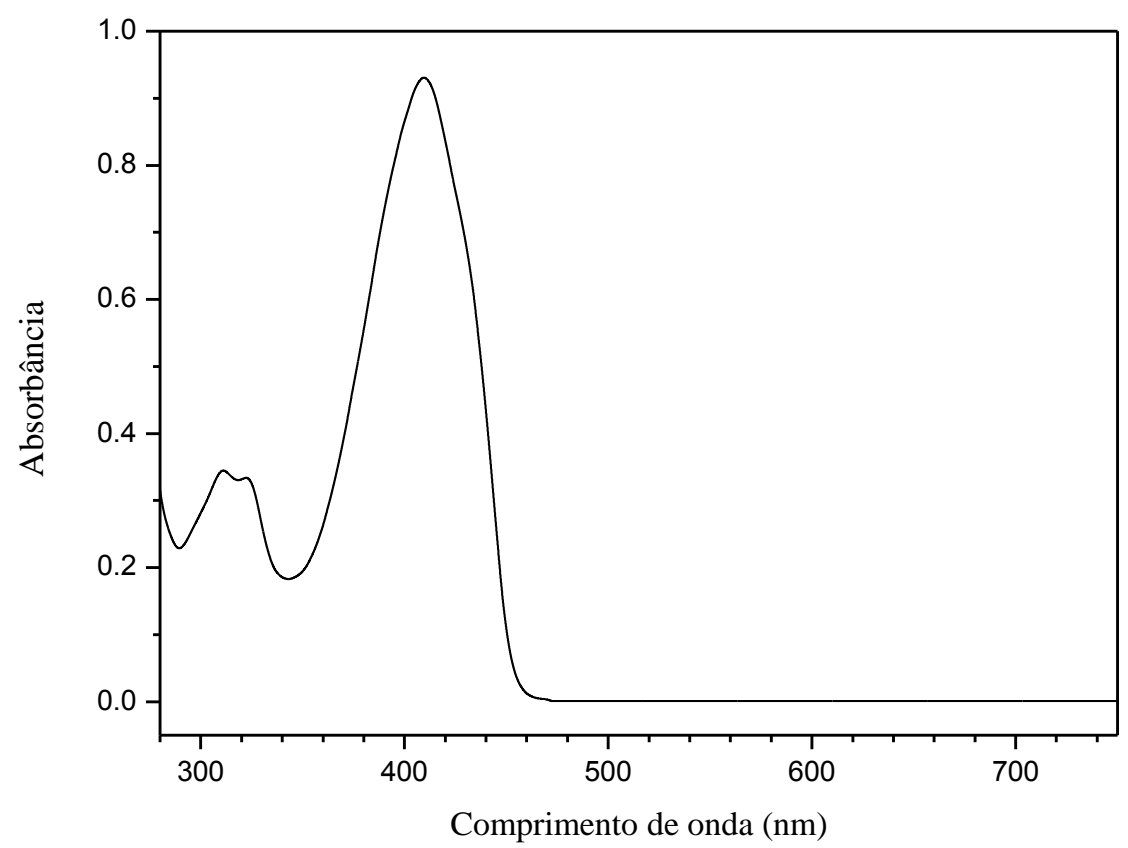

A Tabela 13 apresenta os valores de determinação indireta do rendimento quântico de oxigênio singleto $\left(\Phi_{\Delta}\right)$ empregando-se o DPBF como sequestrador químico relativo à ZnPC em DMSO $\left(\Phi_{\Delta} \mathrm{ZnPC}=0,72\right.$ (121)), calculados através da Equação 5. Esta equação relaciona as constantes cinéticas de decaimento de pseudo-primeira ordem do DPBF na presença da amostra problema e da ZnPC considerando suas respectivas densidades óticas. $\mathrm{O}$ etanol foi utilizado como solvente, pois em experimentos prévios não foram observados agregados dos fotossensibilizadores neste solvente. Todavia, como a solução de referência foi empregada em um solvente distinto ao dos fotossensibilizadores foi necessário aplicar o fator de correção para o índice de refração dos solventes (vide item 4.2.1).

Tabela 13- Valores de rendimento quântico de formação de oxigênio singleto para os fotossensibilizadores utilizando DPBF como sequestrador químico.

\begin{tabular}{cc}
\hline Fotossensibilizador & $\Phi_{\Delta}$ \\
\hline CHL & $0,52 \pm 0,08$ \\
CHL-T & $0,46 \pm 0,03$ \\
HY & $0,02 \pm 0,01$ \\
HY-G & $0,03 \pm 0,01$
\end{tabular}

onde $\Phi_{\Delta}$ é o rendimento quântico de formação de oxigênio singleto. 
$\mathrm{O}$ teste $\mathrm{t}$ de Student não pareado com desvios padrão que não diferem estatisticamente confirmou que os pares CHL/CHL-T e HY/HYG possuem a mesma eficiência de geração de ${ }^{1} \mathrm{O}_{2}$, o que era esperado devido a similaridade dos grupos cromóforos inferidos pelos estudos espectroscópicos.

As clorinas foram ao menos 15 vezes mais eficientes do que as hipericinas na produção de $\Phi_{\Delta}$. Isto era esperado devido ao menor rendimento quântico de fluorescência que estes compostos exibiram (entre 3 a 5 vezes menor que as hipericinas). Portanto, foi evidente a competição da emissão da fluorescência no rendimento quântico da geração dos respectivos estados tripletos.

Comparando-se os valores de $\Phi_{\Delta}$ dos fotossensibilizadores estudados com compostos descritos na literatura (Tabela 14), observa-se que as clorinas apresentam $\Phi_{\Delta}$ equiparáveis ou superiores, enquanto que as hipericinas apresentam valores inferiores. Fotossensibilizadores do tipo clorina são descritos como eficientes na geração de ${ }^{1} \mathrm{O}_{2}$ (69, 77). Em relação aos fotossensibilizadores do tipo hipericina sabe-se que são eficientes em estudos envolvendo TFD, no entanto são descritos valores de $\Phi_{\Delta}$ apenas para compostos encapsulados em lipossomas (88) ou nanopartículas (159).

Tabela 14- Valores de rendimento quântico de fluorescência para fotossensibilizadores descritos na literatura.

\begin{tabular}{cccc}
\hline Fotossensibilizador & $\Phi_{\Delta}$ & Solvente & Referência \\
\hline AM & 0,52 & Etanol & $(160)$ \\
TMMC & 0,59 & DMF & $(76)$ \\
m-THPC & 0,30 & Etanol & $(161)$ \\
Porfirinas & $0,11-0,67$ & DMF & $(162)$ \\
HY-LNC & $0,29-0,35$ & PBS & $(88)$ \\
ZnPTS & $048-0,55$ & DMF & $(158)$
\end{tabular}

onde AM é azul de metileno, TMMC é clorina meso-tetra (3-morfilinometil-4metoxifenil), m-THPC é clorina meta (tetrahidroxifenil), HY-LNC é hipericina encapsulada em nanopartículas lipídicas, ZnPTS são zinco ftalocianinas tetrasulfonadas.

De um modo geral, os resultados obtidos para todos os sequestradores químicos empregados neste estudo comprovaram que CHL, CHL-T, HY e HY-G são capazes de gerar ${ }^{1} \mathrm{O}_{2}$ que é apontado como o principal fator de inativação celular em tratamentos envolvendo TFD $(5,6)$. No entanto, além da geração de ${ }^{1} \mathrm{O}_{2}$ outros fatores devem ser 
considerados para a inativação celular, como por exemplo, acumulação intracelular, geração de outras espécies citotóxicas, influência da dose de luz entre outros.

\subsection{Experimentos celulares}

Com o intuito de se comparar a potencialidade fotodinâmica dos fotossensibilizadores em linhagens celulares, neste estudo foram utilizadas as células epiteliais de carcinoma epidermóide de laringe humana, HEp- 2, de rim de macaco verde africano, Vero e endotelial de cordão umbilical humano, HUVEC.

5.10.1 Acumulação intracelular

O ensaio de acumulação intracelular consiste na quantificação do fotossensibilizador incubado em determinada linhagem celular em função do tempo. Esta metodologia consiste em induzir a ruptura celular para possibilitar a determinação da concentração do fotossensibilizador acumulado na célula.

A determinação da concentração intracelular é realizada através de uma curva padrão para validação do método analítico. Neste trabalho, a melhor sensibilidade da curva analítica para os fotossensibilizadores foi obtida empregando-se etanol como solvente (Figura 35). 
Figura 35- (a) Espectros de emissão de fluorescência da CHL-T em etanol em função da concentração e (b) curva analítica da CHL-T obtida a partir das intensidades de fluorescência integradas em função da concentração $\left(\lambda_{\text {ex }}=610 \mathrm{~nm}\right)$.
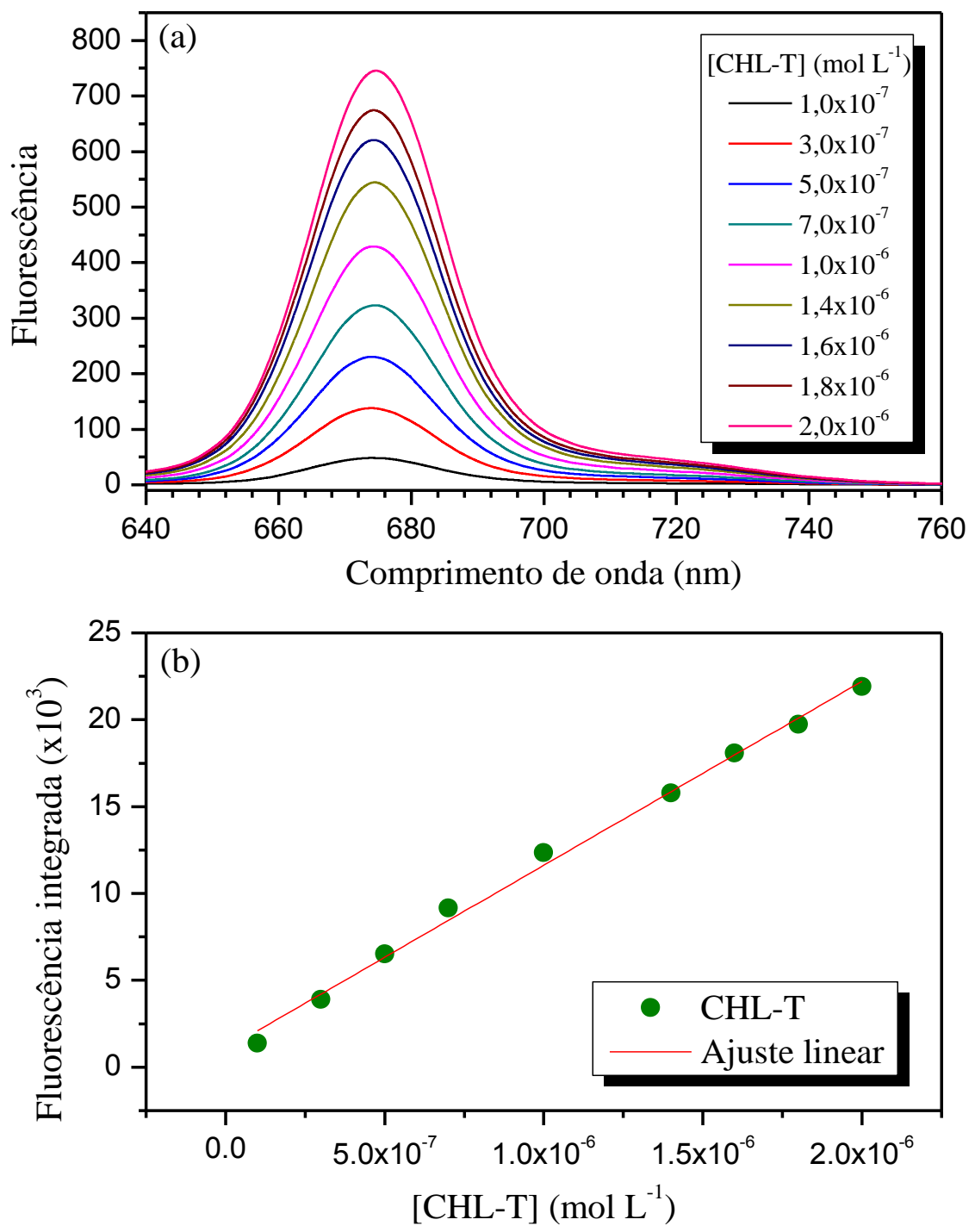

Para a elaboração da curva analítica empregou-se a fluorescência integrada em função da concentração do fotossensibilizador no intuito de minimizar possíveis interferentes devido à agregação do fotossensibilizador. A curva padrão apresentou-se linear, e consequentemente, foi possível quantificar a concentração do fotossensibilizador acumulado utilizando-se a equação da reta para cada um dos fotossensibilizadores (Tabela 15). 
Tabela 15- Parâmetros analíticos da curva padrão de fluorescência para os fotossensibilizadores.

\begin{tabular}{ccccc}
\hline Fotossensibilizador & $\lambda(\mathrm{nm})$ & $\lambda^{\prime}(\mathrm{nm})$ & $\mathrm{r}^{2}$ & $\mathrm{y}$ \\
\hline CHL & 610 & $640-760$ & 0,994 & $192,60+3,80 \times 10^{9} \mathrm{x}$ \\
CHL-T & 610 & $640-760$ & 0,994 & $1051,64+1,06 \times 10^{10} \mathrm{x}$ \\
HY & 545 & $565-800$ & 0,998 & $10,60+2,27 \times 10^{9} \mathrm{x}$ \\
HY-G & 545 & $565-730$ & 0,999 & $7,05+2,89 \times 10^{9} \mathrm{x}$ \\
\hline
\end{tabular}

onde $\lambda$ é o comprimento de onda de excitação, $\lambda$ ' é a faixa de comprimento de onda em que a fluorescência foi integrada, $r^{2}$ é o coeficiente de determinação da regressão linear e y é a equação da reta.

Os valores das concentrações obtidos pela curva padrão dos fotossensibilizadores foram normalizados pela concentração de proteína obtida pelo método de Lowry (125). Este método de determinação de proteína consiste em monitorar a absorção de um composto em $750 \mathrm{~nm}$ que se forma posteriormente à redução do reagente Folin-Ciocalteau quando reage com proteínas na presença de um catalizador (cobre II). A principal vantagem deste método é sua alta sensibilidade. No entanto, apresenta a desvantagem de seguir a lei de Beer-Lambert apenas numa pequena faixa de concentração de proteínas (163).

Semelhante à curva analítica para os fotossensibilizadores, a validação desta metodologia deu-se pela linearidade da curva padrão da absorbância da albumina de soro bovino (BSA) em função de sua concentração em $750 \mathrm{~nm}$. Portanto, a BSA foi empregada como sistema modelo de proteínas para a elaboração da curva padrão para as linhagens celulares empregadas. A equação da reta para a BSA é descrita como $\mathrm{y}=0,01248+1,5626 x$ com $^{2}$ igual a 0,991 (164).

Desta forma, visando-se a determinação da concentração intracelular de CHL, CHL-T, HY e HY-G, foram realizados experimentos incubando-se os fotossensibilizadores entre 0,5 e $4 \mathrm{~h}$. Os resultados de acumulação dos fotossensibilizadores nas células HEp-2 em função do tempo de incubação estão apresentados na Figura 36. 
Figura 36- Acumulação dos fotossensibilizadores em células HEp-2 normalizada pela concentração de proteína em função do tempo de incubação $(n=3)$.

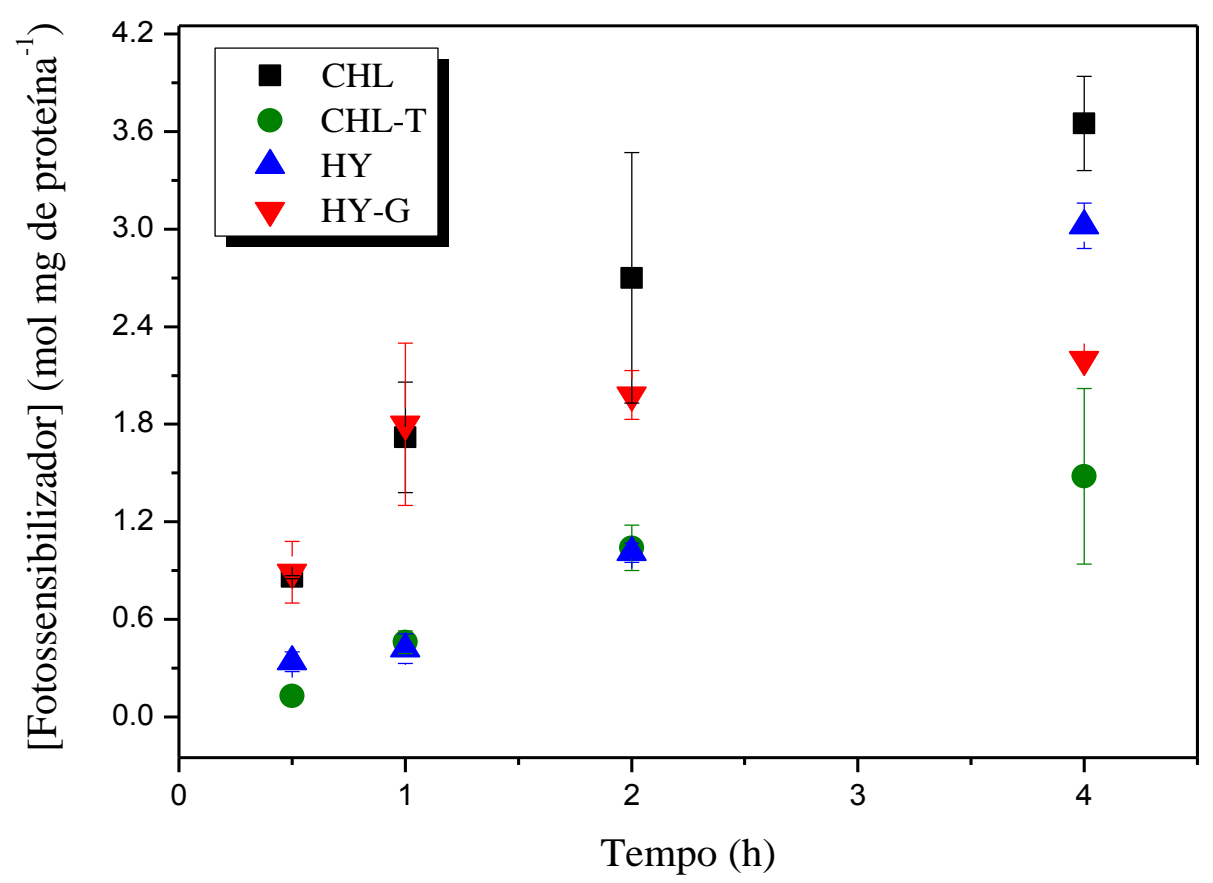

Comparando-se a acumulação intracelular em $2 \mathrm{~h}$, observou-se o aumento da concentração de todos os fotossensibilizadores incorporados às células em função do tempo de incubação. A ordem decrescente de acumulação dos fotossensibilizadores na linhagem HEp-2 foi CHL $>$ HY-G $>$ HY $>$ CHL-T. Sabe-se que a incorporação do fotossensibilizador em linhagens celulares está relacionada a sua lipofilicidade. Um composto que apresente valores de $\log \mathrm{P}$ extremamente positivos ou negativos pode constituir um obstáculo para sua difusão em uma possível aplicação clínica.

Além disso, observa-se que quanto mais hidrofóbico o fotossensibilizador, maior a sua incorporação pelas células do tumor e melhor o efeito da TFD (165). Neste âmbito, os valores de $\log \mathrm{P}(\infty ; 0,16 \pm 0,10$ e -2,02 $\pm 0,61$ para CHL, HY-G e CHL-T, respectivamente) obtidos anteriormente corroboram com os resultados de acumulação celular obtidos para a linhagem HEp-2. Considerando-se a hidrofobicidade da HY (logP $0,48 \pm 0,14)$ era esperado que este composto apresentasse uma acumulação intracelular inferior à da CHL e superior à da HY-G, porém, isto não foi observado.

A Figura 37 demonstra a acumulação intracelular para os fotossensibilizadores nas linhagens celulares não tumorais Vero e HUVEC. 
Figura 37- Acumulação dos fotossensibilizadores em células (a) Vero e (b) HUVEC normalizadas pela concentração de proteína em função do tempo de incubação $(n=3)$.

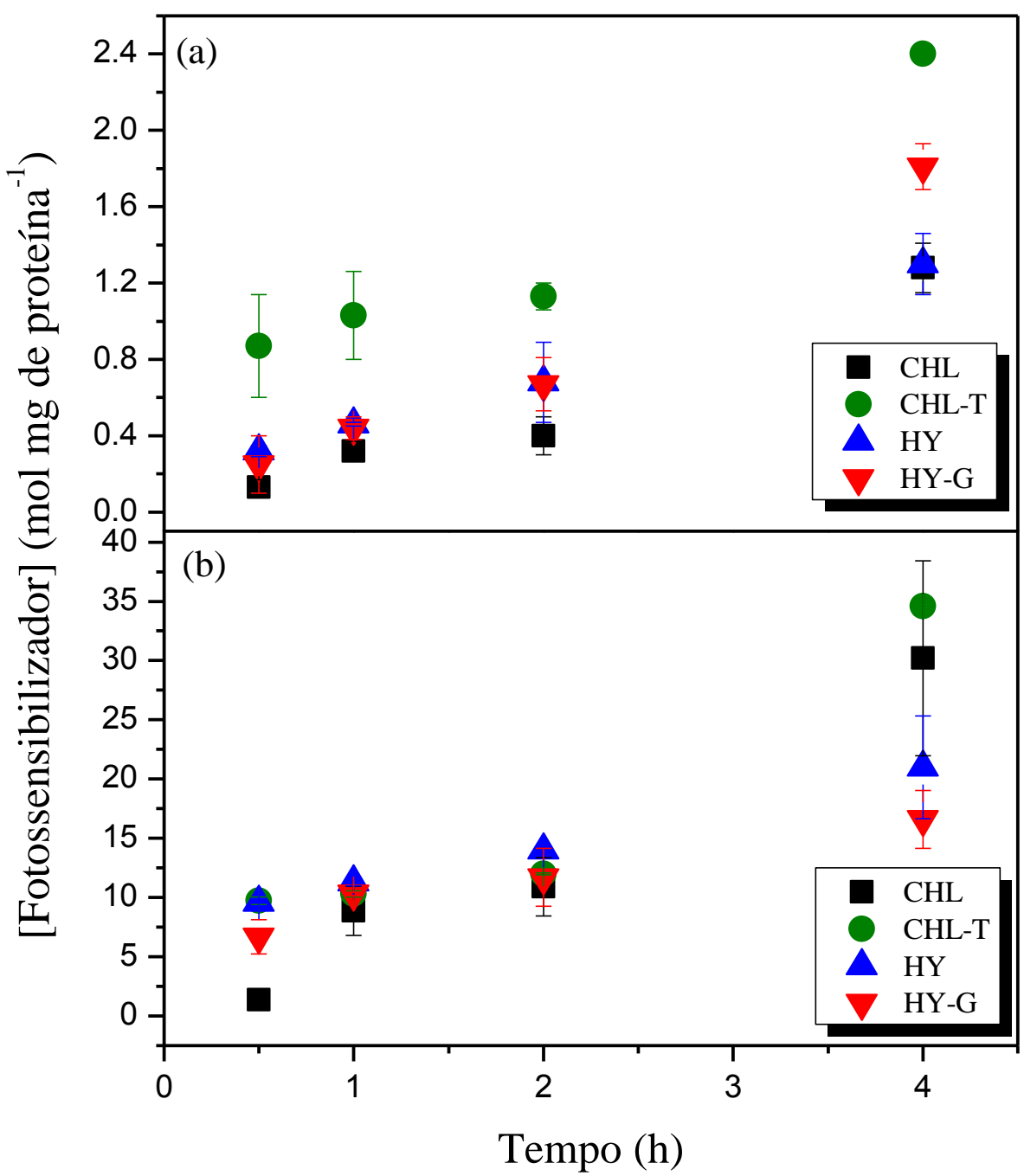

Analogamente ao que foi observado para a linhagem celular HEp-2, as células Vero e HUVEC também apresentaram um aumento da acumulação intracelular em função do tempo até cerca de $2 \mathrm{~h}$ de incubação, posteriormente a este período esse aumento foi mais pronunciado do que na linhagem tumoral. A ordem crescente de acumulação celular dos fotossensibilizadores foi $\mathrm{CHL}-\mathrm{T}>\mathrm{HY}>\mathrm{HY}-\mathrm{G}>\mathrm{CHL}$, ao contrário da ordem observada para as células HEp-2.

Apesar do mecanismo de acumulação intracelular de fotossensibilizadores não estar totalmente elucidado, sabe-se que sua distribuição e localização são influenciadas por vários fatores como concentração do fotossensibilizador, tempo de incubação, tipo de linhagem celular, presença de proteínas, entre outros. 
As diferenças observadas na acumulação intracelular de hipericinas e clorinas nas três linhagens celulares estudadas podem ser explicadas por sua localização subcelular. Gyenge e colaboradores determinaram que em células de carcinoma UMBSCC 745 e UMB-SCC 969 a hipericina acumulou-se em sistemas de membranas (no exterior da membrana, membranas nucleares, complexo de Golgi e perinuclearmente), enquanto que o Foslipos ${ }^{\circledR}$, um formulado de clorina m-THPC solubilizado em sistema lipossomal, difundiu-se no citoplasma celular. Outros estudos descrevem a localização da hipericina em diferentes linhagens celulares desde membranas lipídicas e núcleos até organelas celulares como mitocôndria, retículo endoplasmático, complexo de Golgi ou lisossomos (166). Já a acumulação do Foslipos® em células PC-3, GBC e BDC foi descrita como não localizada em organelas específicas $(58,167)$, corroborando com os resultados obtidos por Gyenge e colaboradores.

\subsubsection{Ensaios citotóxicos}

Estudos comparativos utilizando-se ensaios citotóxicos em culturas celulares é o passo inicial para o protocolo de desenvolvimento de fármacos, pois pode-se mimetizar grande parte das interações que ocorrem in vivo (10). Dentre estes ensaios são possíveis a comparação da eficiência de inibição da proliferação pela contagem de células viáveis. Nestes ensaios citotóxicos utilizou-se o método do MTT para a quantificação indireta do índice de sobrevivência (IS) celular.

\subsubsection{Influência da luz incidida sob as culturas celulares}

O uso de dose de luz excessiva em tratamentos envolvendo irradiação de células em cultura pode causar aquecimento local resultando em alterações nos níveis dos constituintes celulares sensíveis às variações de temperatura, tais como proteínas, DNA ou RNA, acarretando na inibição do crescimento celular (168). Além disso, idealmente, para a aplicação da terapia fotodinâmica, a luz na ausência do composto fotoativo não deve apresentar efeito tóxico às células.

Com o intuito de avaliar a influência da irradiação em linhagens celulares na ausência de fotossensibilizador, neste estudo analisou-se o efeito das doses de luz de 6 e $12 \mathrm{Jcm}^{-2}$ nas linhagens celulares HEp-2, Vero e HUVEC (Figura 38). Para isto empregou-se LED com emissão em $660 \pm 10 \mathrm{~nm}, \mathrm{I}=26,7 \mathrm{~mW} \mathrm{~cm}^{-2}$ e LED emitindo em 
$590 \pm 10 \mathrm{~nm}, \mathrm{I}=15,8 \mathrm{~mW} \mathrm{~cm}^{-2}$ em intervalos de tempos adequado de modo a obter-se as supracitadas doses de luz.

Figura 38- Índice de sobrevivência para as linhagens celulares HEp-2, Vero e HUVEC em função da dose de luz incidida para (a) LED $590 \mathrm{~nm}$ e (b) LED $660 \mathrm{~nm}$. (n=6)

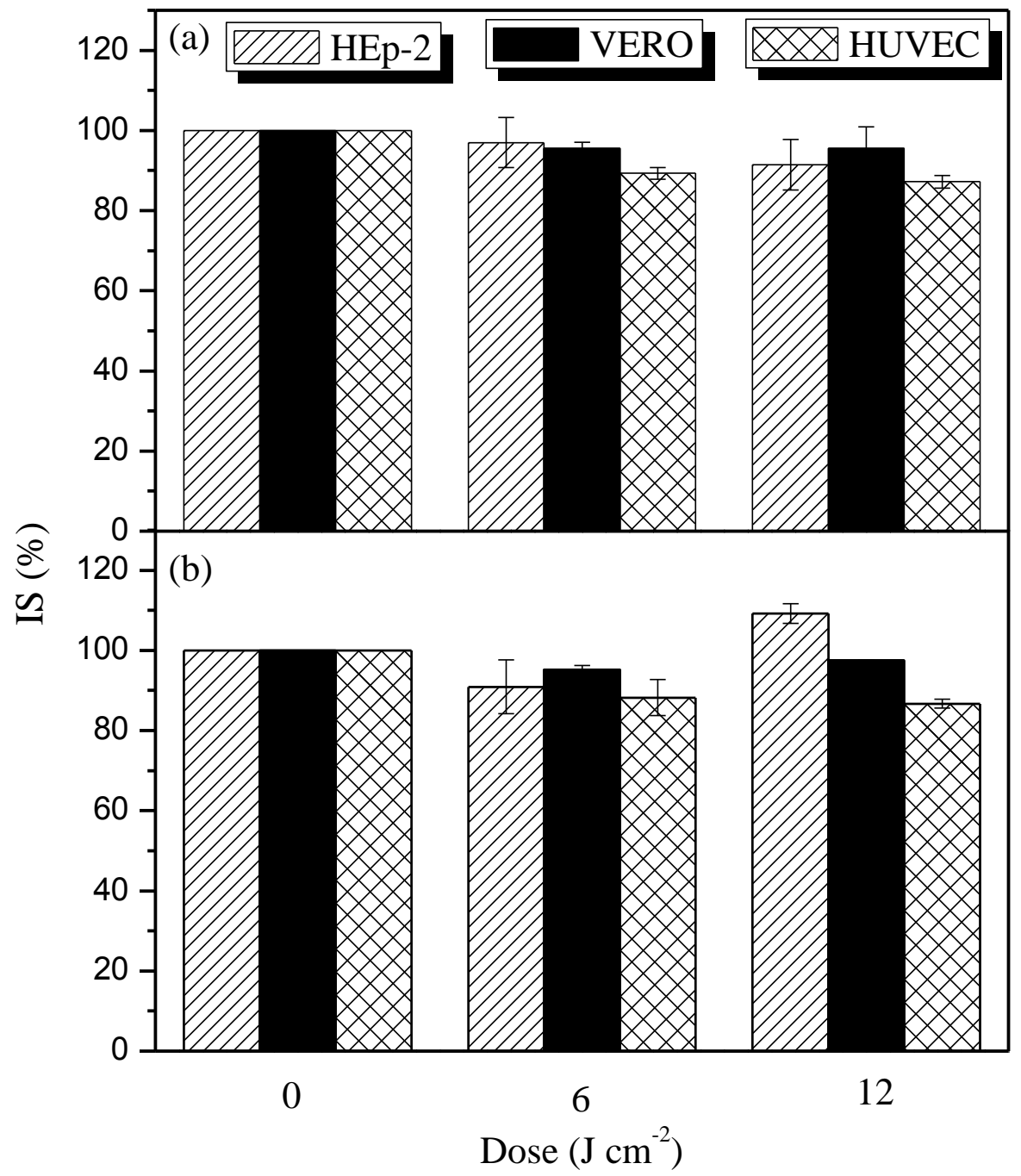

Observou-se que empregando o LED $590 \mathrm{~nm}$ não foram observadas diferenças significativas no IS celular em ambas as doses nas três linhagens celulares estudadas (teste $\mathrm{F}$, seguido de teste $\mathrm{t}$ de Student não pareado para desvios padrão que não diferem significativamente). Todavia, este teste estatístico mostrou que para o LED $660 \mathrm{~nm}$ a irradiação influencia de forma diferente as linhagens celulares. As células HUVEC apresentaram-se mais sensíveis à irradiação do que as demais linhagens celulares. Porém em ambas as doses de luz empregadas o IS das células HUVEC não se alterou significativamente como ocorreu para as outras linhagens. No caso das células HEp-2 a 
menor dose de luz causa uma ligeira diminuição do IS enquanto a maior dose promove uma proliferação celular. Para as células Vero, o IS também é maior na dose de luz $12 \mathrm{~J}$ $\mathrm{cm}^{-2}$.

Song e colaboradores (168) estudaram a fototoxicidade da luz de diversas fontes como LED, lâmpadas incandescente, UVA e UVB sobre três linhagens celulares de mamíferos. Os resultados mostraram que na mesma dose de irradiação todas as culturas celulares foram mais sensíveis à irradiação UVA, seguida da UVB e da luz originada de uma lâmpada incandescente. A luz de LED foi a que apresentou a menor fototoxicidade dentre as fontes de luz estudadas, causando uma redução no IS de aproximadamente $11 \%$ nas células endoteliais e $32 \%$ nas células de fibroblastos devido à peroxidação lipídica.

Portanto, as alterações na sobrevivência celular para as condições experimentais empregadas neste estudo, ou seja, uso de LED como fonte de irradiação, não são significativas, garantindo que a luz na ausência de fotossensibilizador não apresenta a capacidade de inibição do crescimento celular.

5.10.2.2 Análise de citotoxicidade dos fotossensibilizadores utilizando planejamento fatorial

Visando-se a comparação da influência dos fatores (concentração de fotossensibilizador, tempo de incubação e dose de luz) bem como de suas interações sobre o IS de células tumorais (HEp-2) e não tumorais (Vero e HUVEC), realizou-se experimentos de citotoxicidade dos fotossensibilizadores com base em um planejamento fatorial completo $2^{3}$. O planejamento utilizado está apresentado nas primeiras colunas da Tabela 16 e nas colunas subsequentes estão apresentados os resultados de IS para a linhagem celular HUVEC.

De um modo geral, o aumento isolado da concentração (ensaios 1 e 2) ou do tempo de incubação dos fotossensibilizadores (ensaios 1 e 3) promove uma diminuição do IS em todas as linhagens celulares. Essa queda foi intensificada em casos cuja dose de luz empregada encontra-se no nível superior. Comparando-se os ensaios 1 e 5 utilizando-se a HY-G como fotossensibilizador não se observa uma diminuição do IS com o aumento da dose. A influência desses fatores isoladamente sobre o IS é denominada de efeito principal. 
Tabela 16- Planejamento fatorial $2^{3}$ completo para avaliação da citoxicidade dos fotossensibilizadores na linhagem celular HEp-2.

\begin{tabular}{|c|c|c|c|c|c|c|c|}
\hline & & & & \multicolumn{4}{|c|}{ HEp-2 (IS \%) } \\
\hline & [Fotossensibilizador] & $\begin{array}{l}\text { Tempo de } \\
\text { incubação }\end{array}$ & $\begin{array}{l}\text { Dose } \\
\text { de luz }\end{array}$ & CHL & CHL-T & HY & $\mathrm{HY}-\mathrm{G}$ \\
\hline 1 & - & - & - & $90 \pm 10$ & $94 \pm 5$ & $86 \pm 6$ & $74 \pm 1$ \\
\hline 2 & + & - & - & $99 \pm 2$ & $95 \pm 7$ & $79 \pm 8$ & $82 \pm 4$ \\
\hline 3 & - & + & - & $97 \pm 3$ & $95 \pm 4$ & $74 \pm 3$ & $79 \pm 7$ \\
\hline 4 & + & + & - & $70 \pm 5$ & $67 \pm 4$ & $32 \pm 4$ & $50 \pm 7$ \\
\hline 5 & - & - & + & $98 \pm 2$ & $95 \pm 4$ & $91 \pm 7$ & $68 \pm 4$ \\
\hline 6 & + & - & + & $88 \pm 7$ & $99 \pm 2$ & $77 \pm 3$ & $60 \pm 5$ \\
\hline 7 & - & + & + & $98 \pm 2$ & $92 \pm 4$ & $59 \pm 3$ & $61 \pm 3$ \\
\hline 8 & + & + & + & $37 \pm 5$ & $37 \pm 6$ & $14 \pm 2$ & $24 \pm 2$ \\
\hline
\end{tabular}

onde: o tempo de incubação, $(-)=1 \mathrm{~h}$ e $(+)=2 \mathrm{~h}$, dose de luz $(-)=6 \mathrm{Jcm}^{-2}$ e $(+)=12 \mathrm{Jcm}^{-2} \mathrm{e}$ a concentração para CHL $(-)=6 \times 10^{-8} \mathrm{~mol} \mathrm{~L}^{-1} \mathrm{e}(+)=1,2 \times 10^{-7} \mathrm{~mol} \mathrm{~L}^{-1}, \mathrm{CHL}-\mathrm{T} \quad(-)=2 \times 10^{-}$ ${ }^{8} \mathrm{~mol} \mathrm{~L}^{-1}$ e $(+)=4 \times 10^{-8} \mathrm{~mol} \mathrm{~L}^{-1}$ e HY e HY-G $(-)=2 \times 10^{-8} \mathrm{~mol} \mathrm{~L}^{-1}$ e $(+)=4 \times 10^{-8} \mathrm{~mol} \mathrm{~L}^{-1}$.

A ambiguidade observada para o efeito principal da dose de luz evidencia a hipótese de que existem correlações entre um ou mais fatores empregados, que são denominados interações ou efeitos de segunda ordem. Essas correlações devem ser caracterizadas como estatisticamente significativas ou não significativas. A atribuição de significância de um efeito principal ou de uma interação é baseada no teste estatístico denominado t de Student (18).

As Figura 39,Figura 40 e Figura 41 apresentam os efeitos principais, secundários e terciários para as células HEp-2, Vero e HUVEC, aplicando-se este teste com $95 \%$ de confiança. O sinal negativo existente em alguns efeitos caracterizou a diminuição no IS através da troca destes fatores ou interações do nível inferior para o superior. 
Figura 39- Diagrama de Pareto para os efeitos principais e secundários dos fotossensibilizadores na linhagem celular HEp-2. * valores não significativos estatisticamente (teste t de Student, 95\% de confiança).

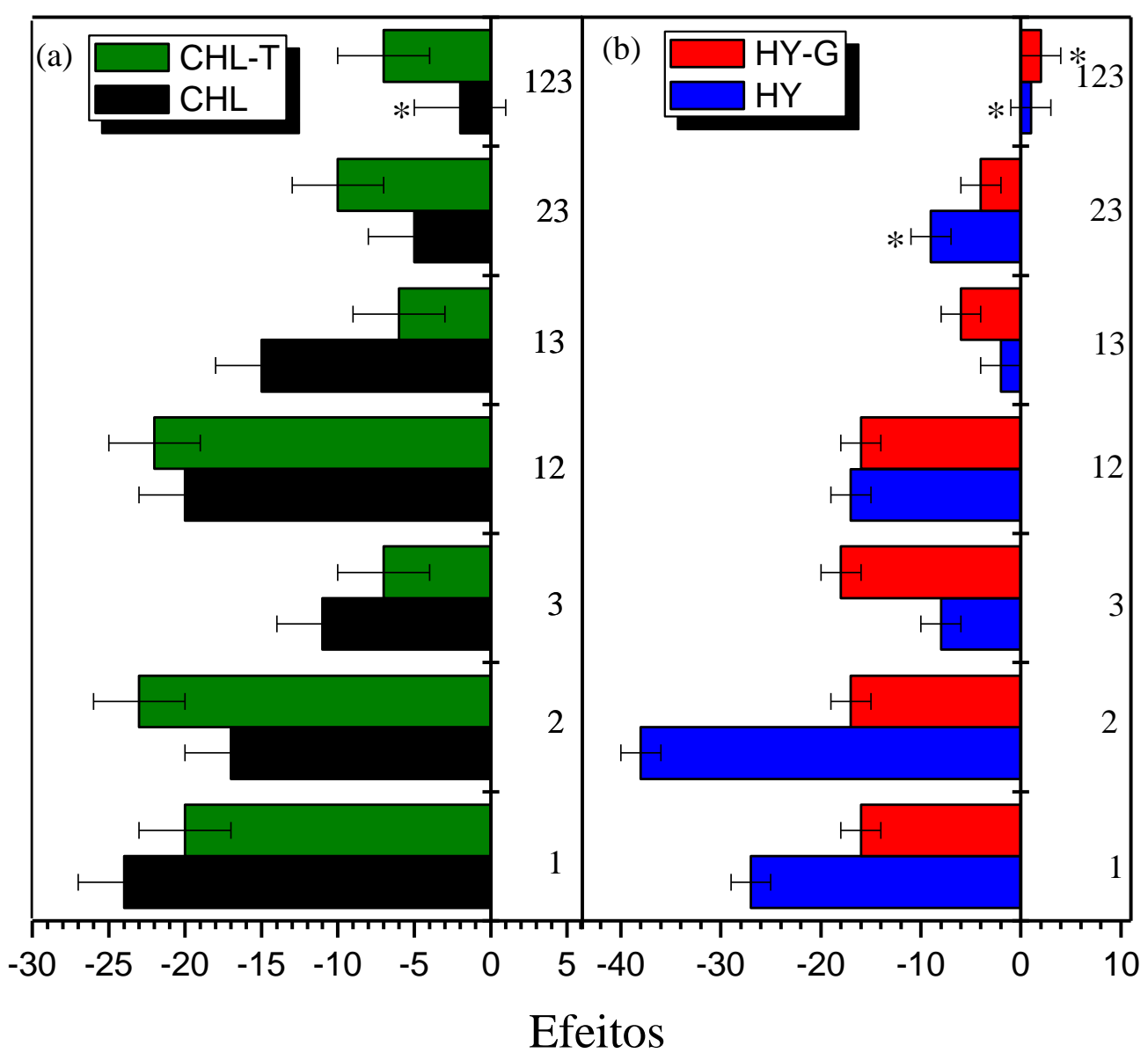

onde 1 é a concentração de fotossensibilizador, 2 é o tempo de incubação do fotossensibilizador na célula e 3 é a dose de luz empregada.

O fator mais expressivo para esta linhagem celular foi a concentração do fotossensibilizador para CHL e CHL-T. No caso da CHL-T, estatisticamente além da concentração, o tempo de incubação é igualmente importante neste processo de inibição celular. Para as clorinas, a interação entre concentração e tempo de incubação se mostrou tão importante quanto os efeitos principais. A dose de luz apresentou-se menos expressiva que a interação entre a concentração do fotossensibilizador e o tempo de incubação.

No caso da HY, o tempo de incubação foi o fator mais expressivo seguido da concentração do fotossensibilizador e da dose de luz empregada. Já para a HY-G observou-se que os três fatores foram igualmente significativos. Similararmente às 
clorinas, a interação entre a concentração do fotossensibilizador e o tempo de incubação foi significativos para ambas as hipericinas.

Figura 40- Diagrama de Pareto para os efeitos principais e secundários dos fotossensibilizadores na linhagem celular Vero. * valores não significativos estatisticamente (teste t de Student, 95\% de confiança).

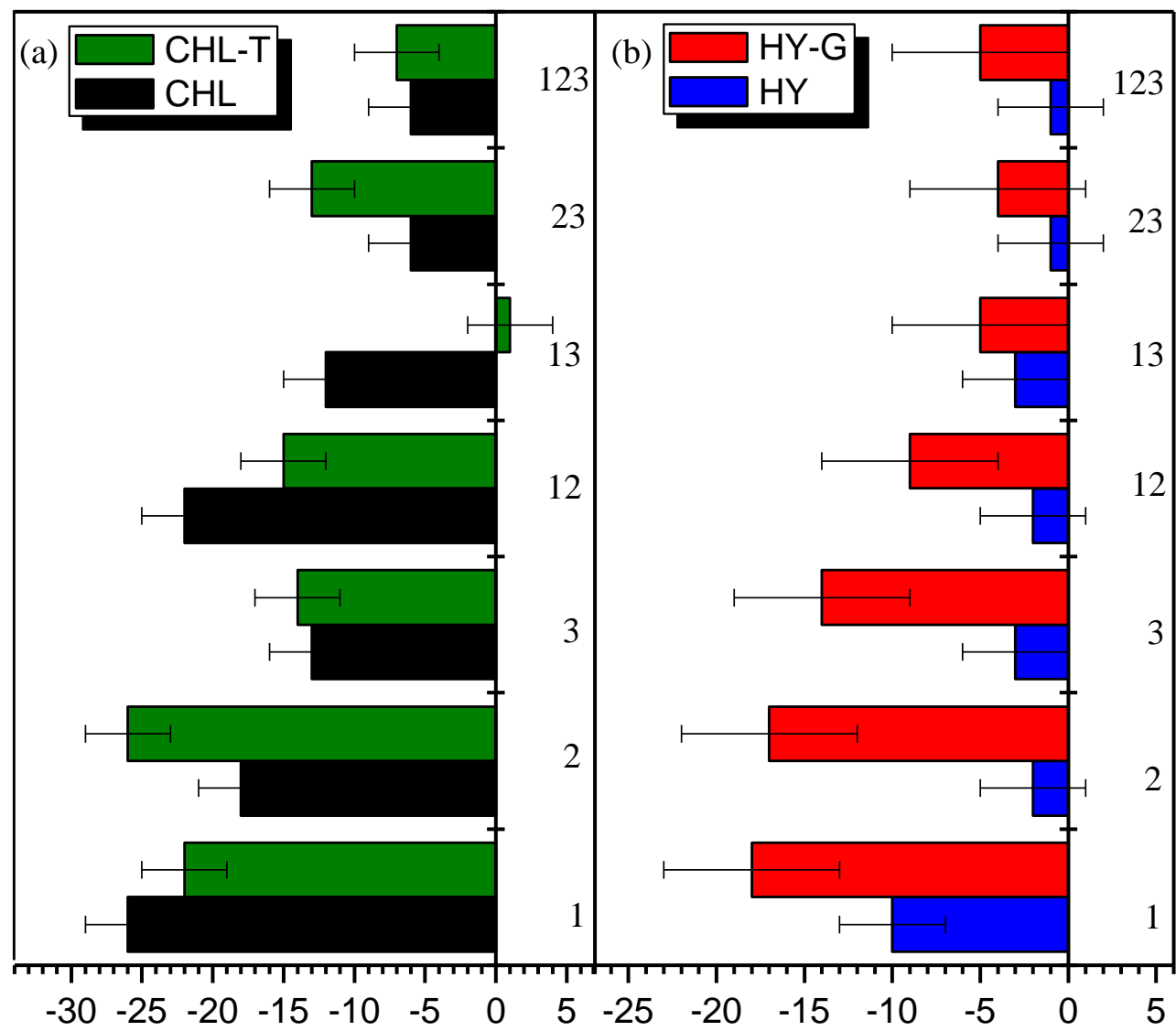

Efeitos

onde 1 é a concentração de fotossensibilizador, 2 é o tempo de incubação do fotossensibilizador na célula e 3 é a dose de luz empregada.

Analogamente, para as células Vero a concentração de CHL e CHL-T permanece inibindo drasticamente o crescimento celular. No entanto, para a CHL-T o tempo de incubação do fotossensibilizador passa a ser o fator mais expressivo. Além disto, o tempo de incubação deixa de ser o fator mais significativo para a HY que agora é expresso pela concentração, seguido do tempo de incubação do fotossensibilizador que é equivalente à dose de luz. Para a HY-G, novamente os três fatores principais são equivalentes. 
A linhagem celular HUVEC é a mais sensível à concentração para todos os fotossensibilizadores nos ensaios fotodinâmicos. Com exceção da CHL-T, o segundo fator mais expressivo foi a dose de luz empregada, corroborando com os resultados de influência da luz incidida sob as culturas celulares. O tempo de incubação foi o segundo fator mais expressivo para este fotossensibilizador.

Figura 41- Diagrama de Pareto para os efeitos principais e secundários dos fotossensibilizadores na linhagem celular HUVEC. * valores não significativos estatisticamente (teste t de Student, 95\% de confiança).

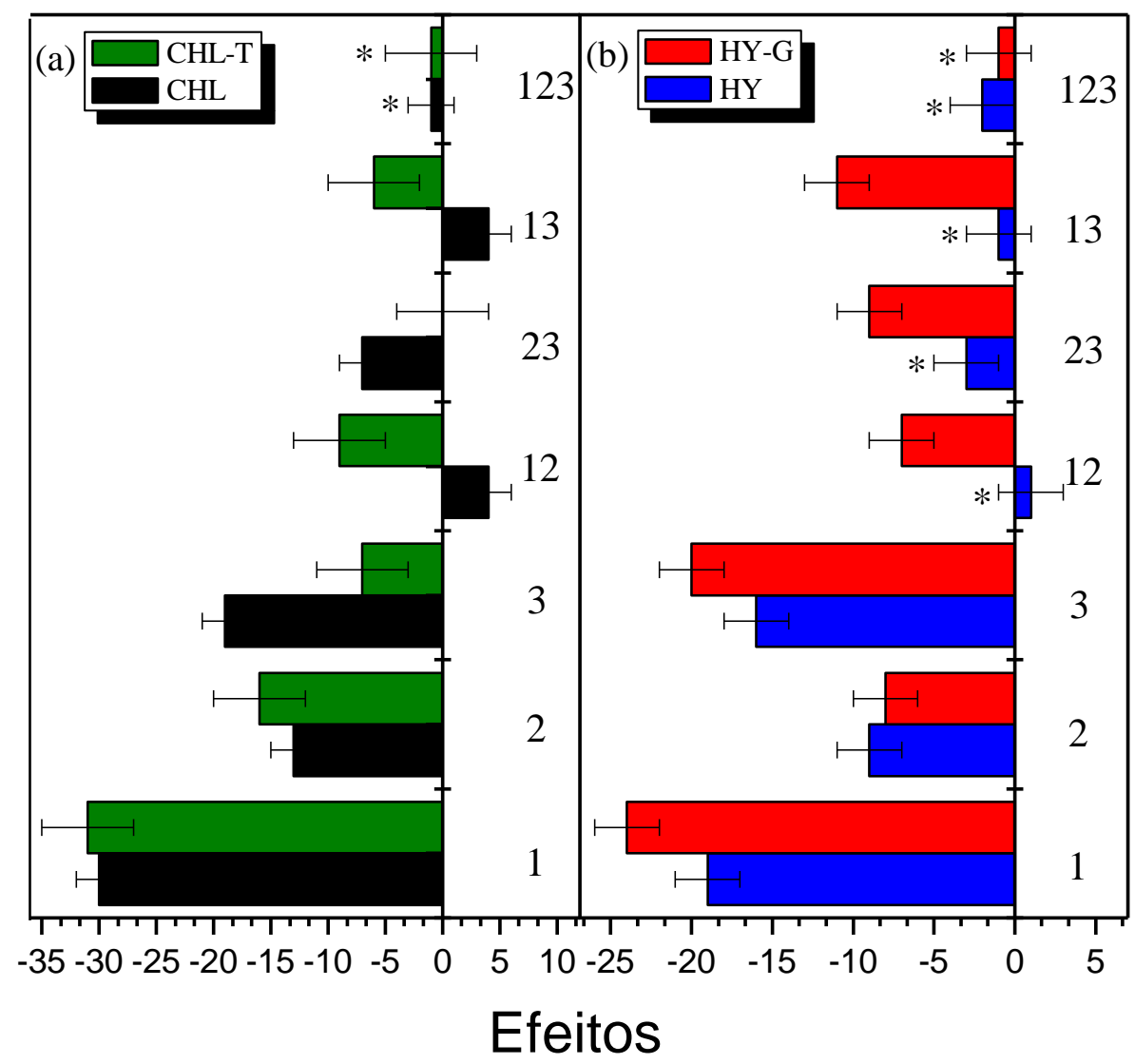

onde 1 é a concentração de fotossensibilizador, 2 é o tempo de incubação do fotossensibilizador na célula e 3 é a dose de luz empregada.

Os efeitos dos fatores e das interações existentes entre eles mostraram que as linhagens celulares foram influenciadas de formas distintas pelas condições do experimento. No entanto, em todos os experimentos observou-se que as interações entre os fatores foram significativas. Sobretudo, essas interações foram mais expressivas que os efeitos principais nos experimentos empregando-se CHL como fotossensibilizador para as linhagens celulares HEp-2 e Vero. 
Observou-se que as interações entre a dose de luz e outros fatores foram cruciais em todas as linhagens celulares. A importância da irradiação associada à excitação do fotossensibilizadores em aplicações de TFD já foi vastamente explorada na literatura, principalmente no que se refere à formação de ${ }^{1} \mathrm{O}_{2}(2,19,20)$.

A análise quimiométrica efetuada nos experimentos de citotoxicidade dos fotossensibilizadores para estas linhagens celulares mostraram que dentro das condições empregadas, o tempo de incubação do fotossensibilizador apresentou-se como um fator relevante para a restrição de morte celular apenas em células cancerígenas. Pode-se empregar concentrações menores de fotossensibilizador e/ou dose de luz e aumentar-se ao tempo de incubação para provocar maiores danos em células tumorais e, consequentemente, preservar as células saudáveis. Ressalta-se ainda que o emprego de baixas concentrações de fotossensibilizador é apropriado para aplicações em TFD, pois minimizam os possíveis efeitos colaterais devido à agregação, bem como a supressão de formação de ${ }^{1} \mathrm{O}_{2}$, como previamente discutido no item 5.9.

\subsubsection{Efeito da dose de luz na citotoxicidade dos fotossensibilizadores}

Com o intuito de analisar-se a toxicidade da CHL, CHL-T, HY e HY-G in vitro, foram realizados ensaios citotóxicos em células HEp-2, Vero e HUVEC e doses de luz 6 e $12 \mathrm{~J} \mathrm{~cm}^{-2}$ como descrito no item 5.10.2.2. Foram realizados ainda, ensaios citotóxicos na ausência de irradiação a fim de se verificar a toxicidade intrínseca dos fotossensibilizadores nas células, ou seja, a citotoxicidade no escuro (dose de luz $0 \mathrm{~J}$ $\mathrm{cm}^{-2}$ ). Como previamente descrito, para todos os fotossensibilizadores e linhagens celulares empregadas o tempo de incubação apresentou-se como fator significativo na inativação celular. Portanto, os ensaios citotóxicos foram realizados em $2 \mathrm{~h}$ de incubação para potencializar o efeito fotodinâmicos dos fotossensibilizadores.

Nestes ensaios citotóxicos utilizou-se a quantificação indireta do IS celular para a determinação da concentração inibitória média $\mathrm{IC}_{50}$, através do programa Calcusyn (128). A determinação do $\mathrm{IC}_{50}$ é baseada na correlação linear de um conjunto de dados de dose-resposta. Especificamente, para os ensaios citotóxicos estes dados são o confronto do IS (normalizado) em função da dose de luz. A regressão linear deste confronto fornece o $\mathrm{IC}_{50}$. Para otimizar a correlação da curva dose-resposta, que normalmente não é linear, as componentes são comumente descritas em sua forma logarítmica na base 10 . 
Em experimentos de fototoxicidade, o $\mathrm{IC}_{50}$ pode ser interpretado como uma quantificação da eficiência de um fotossensibilizador em inviabilizar o crescimento celular. $\mathrm{O} \mathrm{IC}_{50}$ é inversamente proporcional à dose de luz empregada, isto é, quanto menor o $\mathrm{IC}_{50}$ maior a fotoativivade do fotossensibilizador. A Tabela 17 apresenta os resultados de $\mathrm{IC}_{50}$ obtidos para os fotossensibilizadores para a linhagem celular HEp-2 em função da dose de luz empregada.

Tabela 17- Valores de $\mathrm{IC}_{50}\left(\mathrm{nmol} \mathrm{L} \mathrm{L}^{-1}\right)$ para os fotossensibilizadores para a linhagem HEp-2 em função da dose de luz. Tempo de incubação $2 \mathrm{~h}$. Clorinas irradiadas com LED $660 \mathrm{~nm}, \mathrm{I}=27,6 \mathrm{~mW} \mathrm{~cm}{ }^{-2}$ e hipericinas com LED $590 \mathrm{~nm}, \mathrm{I}=15,8 \mathrm{~mW} \mathrm{~cm}{ }^{-2}$ $(n=3)$.

\begin{tabular}{ccccc}
\hline $\mathrm{D}\left(\mathrm{J} \mathrm{cm}^{-2}\right)$ & CHL & CHL-T & HY & HY-G \\
\hline 0 & $1198 \pm 119$ & $1308 \pm 182$ & $1704 \pm 145$ & $1026 \pm 56$ \\
6 & $148 \pm 35$ & $39 \pm 3$ & $25 \pm 2$ & $24 \pm 4$ \\
12 & $57 \pm 6$ & $23 \pm 5$ & $11 \pm 1$ & $14 \pm 2$ \\
\hline
\end{tabular}

onde $\mathrm{D}$ é a dose de luz.

Os resultados mostram que todos os fotossensibilizadores sofreram uma redução nos valores de $\mathrm{IC}_{50}$ em função da dose de luz empregada. Na ausência de irradiação, o $\mathrm{IC}_{50}$ foi cerca de 8, 34, 68 e 43 vezes maior para CHL, CHL-T, HY e HY-G quando comparada à dose $6 \mathrm{~J} \mathrm{~cm}^{-2}$ e 21, 52, 155 e 73 vezes maior quando comparada à dose 12 $\mathrm{J} \mathrm{cm}^{-2}$, respectivamente. Não houve diferenças significativas entre a fototoxicidade de HY e HY-G, todavia a CHL-T apresentou-se como aproximadamente quatro vezes mais fototóxica na dose $6 \mathrm{~J} \mathrm{~cm}^{-2}$ e 2,5 vezes na dose $12 \mathrm{~J} \mathrm{~cm}^{-2}$. Os fotossensibilizadores mais ativos para a inibição do crescimento das células HEp-2 foram as hipericinas.

Apesar das hipericinas apresentarem $\Phi_{\Delta}$ cerca de 15 vezes menores que as clorinas, os valores de $\mathrm{IC}_{50}$ para as hipericinas foram menores, caracterizando uma maior eficiência das hipericinas na inibição celular. Isto pode ser explicado pelo fato do ${ }^{1} \mathrm{O}_{2}$ não ser o único responsável pelo processo de morte celular. Sabe-se que concomitantemente ao mecanismo tipo II, em que há transferência de energia ao oxigênio molecular no estado fundamental (oxigênio tripleto) produzindo ${ }^{1} \mathrm{O}_{2}$, têm-se 
ainda as reações de transferência de elétrons ou de hidrogênio, gerando espécies reativas de oxigênio (mecanismo tipo I) (42).

Resultados similares aos das células HEp-2 foram observados para a linhagem celular Vero (Tabela 18). Na ausência de irradiação, o IC $_{50}$ foi cerca de 10, 25, 36 e 21 vezes maior para CHL, CHL-T, HY e HY-G quando comparado à dose $6 \mathrm{~J} \mathrm{~cm}^{-2}$ e 25 , 60,81 e 55 vezes maior quando comparado à dose $12 \mathrm{~J} \mathrm{~cm}^{-2}$, respectivamente. Os valores de $\mathrm{IC}_{50}$ para as células Vero foram ligeiramente menores do que para as células HEp-2. As linhagens celulares não tumorais são, normalmente, mais sensíveis à ação de agentes externos. Não houve diferenças significativas entre a fototoxicidade de HY e HY-G, todavia a CHL-T apresentou-se como aproximadamente duas vezes mais fototóxica em ambas as doses de luz empregadas. Os fotossensibilizadores mais ativos para a inibição do crescimento das células Vero foram novamente as hipericinas, contudo na dose $12 \mathrm{~J} \mathrm{~cm}^{-2} \mathrm{CHL}-\mathrm{T}$, HY e HY-G foram igualmente eficientes.

Tabela 18- Valores de $\mathrm{IC}_{50}\left(\mathrm{nmol} \mathrm{L} \mathrm{L}^{-1}\right)$ para os fotossensibilizadores para a linhagem Vero em função da dose de luz. Tempo de incubação $2 \mathrm{~h}$. Clorinas irradiadas com LED $660 \mathrm{~nm}, \mathrm{I}=27,6 \mathrm{~mW} \mathrm{~cm}^{-2}$ e hipericinas com LED $590 \mathrm{~nm}, \mathrm{I}=15,8 \mathrm{~mW} \mathrm{~cm}^{-2} \quad(\mathrm{n}=3)$.

\begin{tabular}{ccccc}
\hline $\mathrm{D}\left(\mathrm{J} \mathrm{cm}^{-2}\right)$ & CHL & CHL-T & HY & HY-G \\
\hline 0 & $1146 \pm 189$ & $1133 \pm 207$ & $976 \pm 28$ & $713 \pm 14$ \\
6 & $113 \pm 12$ & $45 \pm 4$ & $26 \pm 4$ & $35 \pm 4$ \\
12 & $45 \pm 4$ & $19 \pm 3$ & $12 \pm 1$ & $13 \pm 2$ \\
\hline
\end{tabular}

onde D é a dose de luz.

A linhagem celular não diferenciada HUVEC apresentou valores de $\mathrm{IC}_{50}$ semelhantes aos das células Vero (Tabela 19). Na dose $0 \mathrm{~J} \mathrm{~cm}^{-2}$, o $\mathrm{IC}_{50}$ foi cerca de 9 , 15, 27 e 15 vezes maior para CHL, CHL-T, HY e HY-G quando comparada à dose $6 \mathrm{~J}$ $\mathrm{cm}^{-2}$ e 30, 34, 61 e 34 vezes maior quando comparada à dose $12 \mathrm{~J} \mathrm{~cm}^{-2}$, respectivamente. Ao contrário do observado para as demais linhagens celulares, para as células HUVEC a HY-G foi menos fototóxica do que a $\mathrm{HY}$. Os valores de $\mathrm{IC}_{50}$ do derivado foram aproximadamente $40 \%$ maiores para ambas as doses de luz. A CHL-T foi cerca de duas vezes mais fototóxica do que a CHL. Os fotossensibilizadores mais ativos para a inibição do crescimento das células HUVEC foram a HY e a CHL-T. 
Tabela 19- Valores de $\mathrm{IC}_{50}\left(\mathrm{nmol} \mathrm{L} \mathrm{L}^{-1}\right)$ para os fotossensibilizadores para a linhagem HUVEC em função da dose de luz. Tempo de incubação $2 \mathrm{~h}$. Clorinas irradiadas com LED $660 \mathrm{~nm}, \mathrm{I}=27,6 \mathrm{~mW} \mathrm{~cm}{ }^{-2}$ e hipericinas com LED $590 \mathrm{~nm}, \mathrm{I}=15,8 \mathrm{~mW} \mathrm{~cm}^{-2}$ $(n=3)$.

\begin{tabular}{ccccc}
\hline $\mathrm{D}\left(\mathrm{J} \mathrm{cm}^{-2}\right)$ & CHL & CHL-T & HY & HY-G \\
\hline 0 & $1201 \pm 92$ & $807 \pm 115$ & $901 \pm 114$ & $779 \pm 24$ \\
6 & $136 \pm 15$ & $53 \pm 6$ & $33 \pm 4$ & $53 \pm 3$ \\
12 & $40 \pm 5$ & $24 \pm 2$ & $15 \pm 5$ & $23 \pm 2$ \\
\hline
\end{tabular}

onde D é a dose de luz.

A ação de todos os fotossensibilizadores foi intensamente potencializada pela irradiação. Em geral, observou-se uma queda de cerca de $50 \%$ nos valores de $\mathrm{IC}_{50} \mathrm{em}$ todas as linhagens celulares quando a dose de luz foi aumentada em duas vezes para todos os fotossensibilizadores. Isto caracteriza a dependência da dose de luz para a inativação celular nos ensaios fotodinâmicos.

AlSalhi e colaboradores (2012) (169) analisaram o efeito da dose de luz na fototoxicidade da protoporfirina IX induzido pelo Ácido 5-Aminolevulínico (ALA), irradiado com LED $633 \mathrm{~nm}$ em linhagens celulares. Os resultados mostraram que o IS das células tumorais HEp-2 e A-549 decresceu drasticamente em função do tempo de exposição à irradiação. Os autores concluíram que a morte celular foi dependente da dose de energia a que as células foram submetidas. As células epiteliais cancerígenas humanas A-431 na presença de clorina m-THPC irradiadas com LED $660 \pm 5 \mathrm{~nm}$, I=16 $\mathrm{W} / \mathrm{m}^{2}$ tiveram o IS reduzido em cerca de $50 \%$ com apenas um minuto de irradiação e aproximadamente $80 \%$ em três minutos de irradiação (170).

Outro fator que contribui para aumentar a eficiência é a acumulação intracelular. Estudos em células endoteliais de córnea humana, HCECs, mostraram que a clorina e-6 aumentou a fototoxicidade em função da concentração acumulada em ensaios fotodinâmicos (81). Como previamente descrito no item 5.10.1, a acumulação celular foi não somente dependente da linhagem celular estudada como também da lipofilicidade dos compostos. Para as células cancerígenas HEp-2, a CHL e a HY-G apresentaram valores de acumulação intracelular superiores aos seus respectivos pares. Entretanto, nas linhagens celulares não tumorais Vero e HUVEC isto não foi observado. 
5.10.2.4 Comparação entre os valores de $\mathrm{IC}_{50}$ experimental e teórico

A aplicação do planejamento fatorial promove o estudo simultâneo de diversas variáveis e, consequentemente, a possibilidade de triagem destes fatores e suas interações. Além disso, esta ferramenta estatística resulta em um modelo empírico que faz uso de uma função matemática para descrever o perfil das respostas observadas (18).

Neste trabalho utilizou-se uma adaptação do modelo estatístico comumente obtido por quimiometria para a determinação do $\mathrm{IC}_{50}$ dos fotossensibilizadores nas linhagens celulares estudadas. O modelo empírico empregado foi formulado a partir dos valores de cada um dos efeitos e interações significativas obtidas no planejamento fatorial para cada fotossensibilizador e linhagem celular separadamente, descritas no item 5.10.2.2.

A Tabela 20 apresenta os valores dos fatores e interações significativas para a HY determinadas pelo planejamento fatorial para a linhagem celular HUVEC.

Tabela 20- Efeitos calculados para o planejamento fatorial $2^{3}$ para a HY-G na linhagem celular HUVEC.

\begin{tabular}{cc}
\hline Efeito & Valores \\
\hline Média & $57 \pm 4$ \\
1 & $-24 \pm 2$ \\
2 & $-8 \pm 2$ \\
3 & $-20 \pm 2$ \\
12 & $-7 \pm 2$ \\
13 & $-11 \pm 2$ \\
23 & $-9 \pm 2$ \\
123 & $-1 \pm 2^{*}$ \\
\hline $\mathrm{t}$ & 5
\end{tabular}

onde 1 é a concentração de HY-G, 2 é o tempo de incubação, 3 é a dose de luz e t é o valor mínimo para que o efeito seja significativo.

A equação quimiométrica que descreve o perfil do IS desta célula na presença de HY-G foi determinada considerando-se a média e a metade dos valores dos efeitos significativos: 
$y=57-12 \times[\mathrm{HYG}]-4 \times \mathrm{t}-10 \times \mathrm{D}-3,5 \times[\mathrm{HYG}] \times \mathrm{t}-5,5 \times[\mathrm{HYG}] \times \mathrm{D}-4,5 \times \mathrm{t} \times \mathrm{D} \quad$ Equação 17 onde [HYG] é a concentração de HY-G, t é o tempo de incubação e D é a dose de luz.

Para a determinação do $\mathrm{IC}_{50}$ teórico, aplicou-se a Equação 17, mantendo-se para todos os casos o tempo de incubação do fotossensibilizador no nível superior e substituindo y por 50, e os efeitos por suas variáveis codificadas (-1 ou 1). Este cálculo resulta no valor codificado da concentração de HY-G necessária para inibir o crescimento de $50 \%$ das células para as doses 6 e $12 \mathrm{~J} \mathrm{~cm}^{-2}$. Posteriormente, calculou-se o valor de $\mathrm{IC}_{50}$ teórico, a partir do valor de $\mathrm{IC}_{50}$ codificado.

$\mathrm{O}$ valor de $\mathrm{IC}_{50}$ teórico calculado a partir desta modelagem empírica foi determinado para os demais fotossensibilizadores para a linhagem celular HUVEC e os resultados estão ilustrados na Figura 42.

Figura 42- Valores de $\mathrm{IC}_{50}$ experimentais e teóricos em função da dose de luz para (a) CHL e CHL-T e (b) HY e HY-G para a linhagem celular HUVEC.
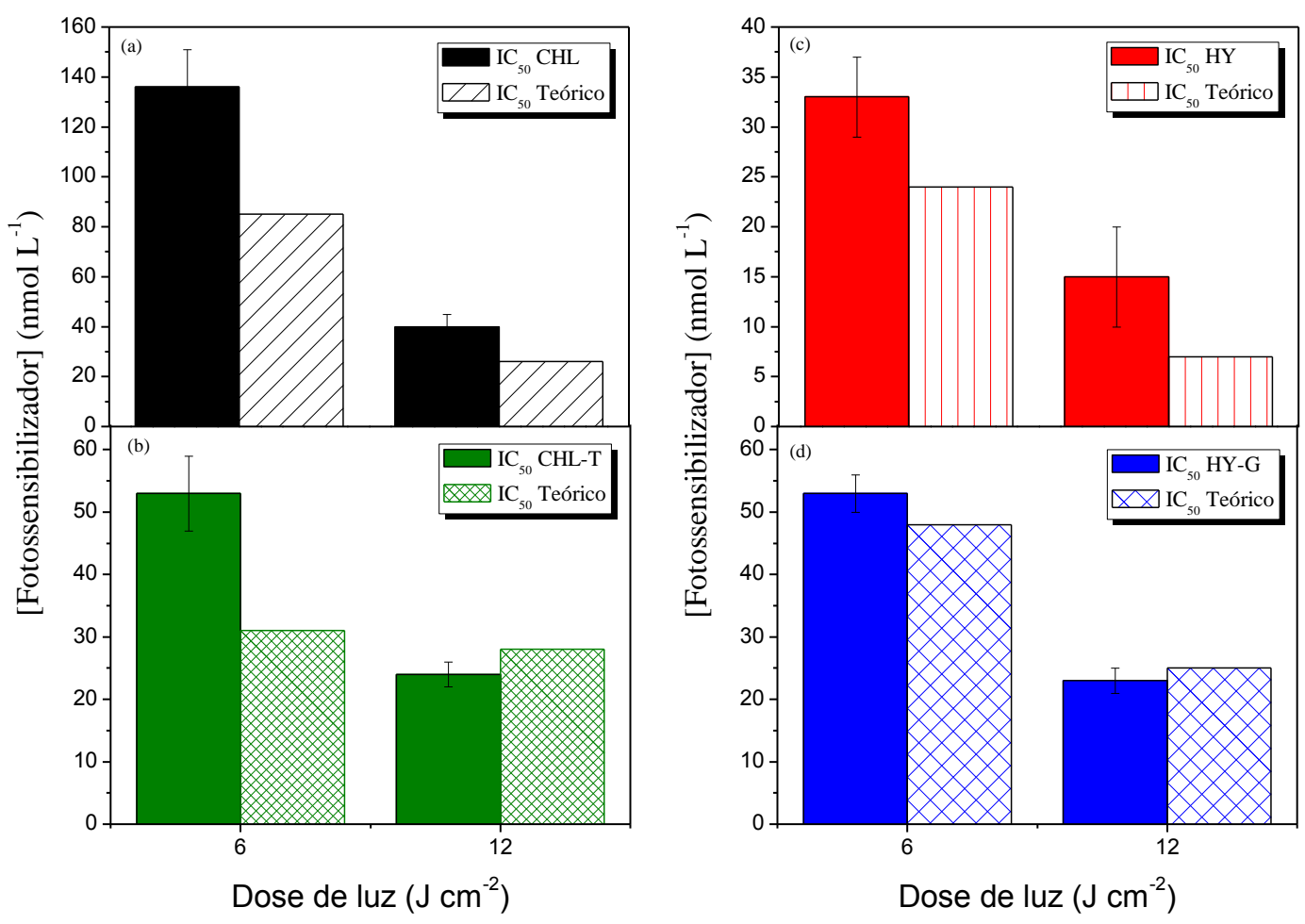
Observa-se que os valores teóricos de $\mathrm{IC}_{50}$ calculados empregando-se o modelo empírico correspondem aos valores de $\mathrm{IC}_{50}$ obtidos experimentalmente. $\mathrm{O}$ teste $\mathrm{t}$ de Student corrobora que não há diferenças significativas entre os valores experimentais e teóricos para a maioria dos fotossensibilizadores. As exceções de acurácia do modelo foram a CHL e CHL-T na dose $6 \mathrm{~J} \mathrm{~cm}^{-2}$ que apresentaram valores teóricos de $\mathrm{IC}_{50}$ incompatíveis com os valores experimentais. No caso da HY, essa diferença foi de aproximadamente $28 \%$ inferior ao valor experimental, indicando que, apesar de não ser exato, ainda seria possível determinar o $\mathrm{IC}_{50}$ nestas condições.

A comparação entre o valor de $\mathrm{IC}_{50}$ experimental e teórico para as clorinas fotossensibilizadores nas linhagens celulares HEp-2 e Vero está descrita na Tabela 21. Analogamente ao que foi observado para a linhagem celular HUVEC, o valor do $\mathrm{IC}_{50}$ teórico é compatível com o valor do $\mathrm{IC}_{50}$ experimental (teste t de Student) para todos os fotossensibilizadores na dose $6 \mathrm{~J} \mathrm{~cm}^{-2}$. As exceções de compatibilidade foram os valores de $\mathrm{IC}_{50}$ para a maioria dos fotossensibilizadores na dose $12 \mathrm{~J} \mathrm{~cm}^{-2}$, sendo cerca de $50 \%$ superiores ao valor experimental para em ambas as linhagens celulares.

Tabela 21-Valores de $\mathrm{IC}_{50}$ experimentais e teóricos $\left(\mathrm{nmol} \mathrm{L}^{-1}\right)$ em função da dose de luz para os fotossensibilizadores nas linhagens celulares HEp-2 e VERO.

\begin{tabular}{c|c|c|c|c|c|c|c|c}
\cline { 2 - 8 } & \multicolumn{4}{c|}{ HEp-2 } & \multicolumn{4}{c}{ VERO } \\
\cline { 2 - 9 } & \multicolumn{2}{|c|}{ Dose 6 $\left(\mathrm{J} \mathrm{cm}^{-2}\right)$} & \multicolumn{2}{c}{ Dose $12\left(\mathrm{~J} \mathrm{~cm}^{-2}\right)$} & \multicolumn{2}{c}{ Dose 6 $\left(\mathrm{J} \mathrm{cm}^{-2}\right)$} & \multicolumn{2}{c}{ Dose $12\left(\mathrm{~J} \mathrm{~cm}^{-2}\right)$} \\
\cline { 2 - 9 } & $\mathrm{IC}_{50} \mathrm{E}$ & $\mathrm{IC}_{50} \mathrm{~T}$ & $\mathrm{IC}_{50} \mathrm{E}$ & $\mathrm{IC}_{50} \mathrm{~T}$ & $\mathrm{IC}_{50} \mathrm{E}$ & $\mathrm{IC}_{50} \mathrm{~T}$ & $\mathrm{IC}_{50} \mathrm{E}$ & $\mathrm{IC}_{50} \mathrm{~T}$ \\
\hline CHL & $148 \pm 35$ & 159 & $57 \pm 6$ & 108 & $113 \pm 2$ & 123 & $45 \pm 4$ & 88 \\
CHL-T & $39 \pm 3$ & 51 & $23 \pm 5$ & 35 & $45 \pm 4$ & 44 & $19 \pm 3$ & 23 \\
HY & $25 \pm 2$ & 32 & $11 \pm 1$ & 24 & $26 \pm 4$ & 34 & $12 \pm 1$ & 28 \\
HY-G & $24 \pm 4$ & 41 & $11 \pm 1$ & 26 & $35 \pm 4$ & 37 & $13 \pm 2$ & 33 \\
\hline
\end{tabular}

onde: $\mathrm{IC}_{50} \mathrm{E}$ e $\mathrm{IC}_{50} \mathrm{~T}$ são os valores de $\mathrm{IC}_{50}$ experimental e teórico $\left(\mathrm{nmol} \mathrm{L}{ }^{-1}\right.$ ), respectivamente.

A melhor compatibilidade de $\mathrm{IC}_{50}$ experimental e teórico foi obtida nos casos em que a concentração do fotossensibilizador empregada para o nível inferior era aproximadamente o valor do $\mathrm{IC}_{50}$ experimental na dose $12 \mathrm{~J} \mathrm{~cm}^{-2}$, e para o nível superior era semelhante ao valor do $\mathrm{IC}_{50}$ experimental na dose $6 \mathrm{~J} \mathrm{~cm}^{-2}$. Contudo, esta limitação do modelo empírico foi observada apenas quando os experimentos de $\mathrm{IC}_{50}$ experimental foram realizados, ou seja, posteriormente à obtenção do planejamento experimental. Em experimentos em que se empregou concentrações distintas à 
limitação do modelo, observou-se que foi possível a obtenção do valor de $\mathrm{IC}_{50}$, no entanto o valor teórico foi sub ou superestimado.

Esta desvantagem do modelo empírico pode ser facilmente superada, considerando-se que para a aplicação do planejamento fatorial são necessários apenas oito ensaios para cada fotossensibilizador em cada linhagem celular, enquanto que para a determinação experimental este valor foi de pelo menos 72 ensaios (12 concentrações, em duas doses e três experimentos). Ressalta-se ainda que o valor do $\mathrm{IC}_{50}$ teórico é uma estimativa do valor experimental determinado por amostragem e deve ser usado como apoio para a determinação experimental deste parâmetro fotodinâmico. 


\section{CONCLUSÃO}

\section{Conclusão}

Neste trabalho foram estudadas as propriedades físico-químicas e fotodinâmicas de quatro moléculas com potencial aplicação como fotossensibilizadores: a CHL, a HY e seus derivados obtidos por meio de inserções dos grupamentos hidrofílicos trizma (CHL-T) e glucamina (HY-G).

A inserção dos grupamentos hidrofílicos acarretou no aumento de 16,7 e 20,3\% na solubilidade em meio aquoso da CHL-T e HY-G quando comparadas com CHL e HY, respectivamente. Não foram observados desvios da Lei de Beer-Lambert para os fotossensibilizadores estudados indicando que estes compostos não sofreram autoagregação. Todavia, considerando-se a redução da intensidade e alargamento das bandas de absorção e emissão de fluorescência nula em meio aquoso e neutro, sugere-se que a solubilidade de todos os fotossensibilizadores seja parcial e que parte do composto possa estar segregado da solução.

$\mathrm{O}$ processo de agregação dos fotossensibilizadores em função do $\mathrm{pH}$ e presença de íons em solução foi relacionado com a existência de cargas elétricas na molécula. As clorinas exibiram três espécies distintas em função do $\mathrm{pH}$ que foram atribuídas às formas protonada, neutra e desprotonada, identificadas em meio ácido, neutro e alcalino, respectivamente. A primeira transição foi atribuída à protonação dos imino nitrogênios do macrociclo, enquanto que transição em meio alcalino foi devido à retirada destes nitrogênios e/ou ruptura do anel macrocíclico.

Analogamente, foram identificadas três espécies de hipericina coexistentes em solução em função do $\mathrm{pH}$ atribuídas às formas neutra, aniônica e dianiônica. As transições foram atribuídas à retirada de prótons da região de baía e periferia da molécula. Somente as formas bivalentes de clorinas e hipericinas foram definidas como solúveis pelos espectros de absorção e emissão de fluorescência, sugerindo que nas demais faixas de $\mathrm{pH}$ possam existir agregados do tipo $\mathrm{H}$.

Contudo, os agregados formados em meio aquoso neutro foram prontamente solubilizados pelas micelas dos surfactantes iônicos CTAB e SDS e o não iônico Tween 20. As clorinas apresentaram ainda formação de adutos pré-micelares com os surfactantes iônicos. Tais adutos asseguraram a solubilização parcial dos agregados até mesmo abaixo da concentração micelar crítica. No caso das hipericinas não foram 
observadas as formações desses adutos, porém todos os surfactantes garantiram a total solubilidade dos agregados de fotossensibilizadores no ambiente micelar.

O fotobranqueamento foi observado para todos os fotossensibilizadores pela diminuição das intensidades de absorção e emissão de fluorescência com cinética de primeira ordem. A ordem de susceptibilidade à irradiação foi CHL-T> CHL> HYG>HY. Em solução aquosa a taxa de fotobranqueamento foi cerca de $50 \%$ inferior àquela em DMSO. Em nenhum solvente identificou-se a formação de foto-produtos. Esta redução do fotobranqueamento em meio aquoso foi atribuída à formação de agregados do tipo $\mathrm{H}$ (face a face) corroborando com o modelo previamente proposto.

Os parâmetros fotofísicos indicaram que as características estruturais das clorinas foram mais favoráveis a sofrerem cruzamento intersistema do que as das hipericinas. Esta hipótese foi confirmada com a determinação de rendimento quântico de formação de oxigênio singleto empregando-se o 1,3-difenilisobenzofurano como dosímetro químico resultando que as clorinas foram até 15 vezes mais eficientes dos que as hipericinas. Entretanto, em microambiente hidrofóbico e utilizando-se o ácido úrico e o p-nitroso dimetilanilina como capturadores de oxigênio singleto, não foram observadas diferenças significativas no potencial de CHL, HY e HY-G em gerar este radical citotóxico, provavelmente devido à solubilidade parcial destes compostos nestas condições.

Em concordância com a atividade fotodinâmica, os ensaios celulares mostraram que os fotossensibilizadores acumularam-se no interior de células tumorais HEp-2 proporcionalmente e, em células não tumorais Vero e HUVEC, inversamente à sua lipofilicidade.

Em geral, a $\mathrm{HY}$ apresentou os menores valores de $\mathrm{IC}_{50} \mathrm{em}$ todas as doses de luz e linhagens celulares estudadas. A HY-G apresentou valores ligeiramente superiores aos da HY em todas as condições, sugerindo que, apesar de ser mais solúvel, este derivado não é mais fototóxico que $\mathrm{HY}$. Os valores de $\mathrm{IC}_{50}$ da $\mathrm{CHL}-\mathrm{T}$ foram em média, o dobro dos exibidos pela HY e consequentemente, os maiores valores foram exibidos pela CHL. A irradiação potencializou em 150 vezes a fototoxicidade da clorina.

A dose de luz empregada foi inversamente proporcional ao valor do $\mathrm{IC}_{50}$, certificando a fotoatividade dos compostos estudados. A irradiação não provocou morte significativa na ausência de fotossensibilizador e nas condições experimentais empregadas. Sugere-se reduzir a concentração dos fotossensibilizadores e aumentar a dose de luz no intuito de inibir o crescimento celular e favorecer as condições farmacocinéticas. 
A aplicação do planejamento fatorial $2^{3}$, cujos fatores foram concentração do fotossensibilizador, tempo de acumulação do fotossensibilizador no interior da célula e dose de luz, possibilitou não apenas a determinação da hierarquia de parâmetros significativos bem como de suas interações para o processo de inativação celular. As significâncias destes parâmetros foram diferentes para células tumorais e para não tumorais. Desta forma, pode-se manipular os fatores estudados de modo a afetar uma maior quantidade de células tumorais causando menores danos às células saudáveis, promovendo assim a seletividade.

Além disso, esta ferramenta estatística forneceu um modelo matemático satisfatório para a estimativa do $\mathrm{IC}_{50}$ dos fotossensibilizadores em condições variadas de tempo de incubação e dose de luz, baseado num número mínimo de ensaios.

A aplicabilidade desses fotossensibilizadores em diagnósticos e tratamentos fotodinâmicos é promissora devido as suas características estruturais, químicas e fotofísicas que permitem que as transições eletrônicas destes fotossensibilizadores sejam energeticamente favoráveis, implicando assim, na geração de fluorescência e/ou espécies citotóxicas que acarretam a destruição de células indesejáveis. Além disso, devido ao aumento da solubilidade em meio aquoso dos derivados, a aplicação intravenosa e a eliminação destes compostos são facilitadas pelo organismo. 


\section{REFERÊNCIAS BIBLIOGRÁFICAS}

1 SHARMAN, W. M.; ALLEN, C. M.; VAN LIER, J. E. Photodynamic therapeutics: basic principles and clinical applications. Drug Discovery Today, v. 4, n. 11, p. 507$517,1999$.

2 HENDERSON, B. W.; DOUGHERTY, T. J. How does photodynamic therapy work? Photochemistry and Photobiology, v. 55, n. 1, p. 145-57, 1992.

3 FOOTE, C. S. Definition of type-I and type-II photosensitized oxidation.

Photochemistry and Photobiology, v. 54, n. 5, p. 659-659, 1991.

4 BENOV, L. Photodynamic therapy: current status and future directions. Medical Principles and Practice, v. 24, n. 1, p. 14-28, 2015.

5 DOUGHERTY, T. J. Photosensitization of malignant tumors. Seminars in Surgical Oncology, v. 2, n. 1, p. 24-37, 1986.

6 DOUGHERTY, T. J.; GOMER, C. J.; HENDERSON, B. W.; JORI, G.; KESSEL, D.; KORBELIK, M.; MOAN, J.;PENG, Q. Photodynamic therapy. Jounal of the National Cancer Institute, v. 90, n. 12, p. 889-905, 1998.

7 FISCHER, F.; GRASCHEW, G.; SINN, H.J.; MAIER-BORST, W.; LORENZ, W.J.; SCHLAG, P.M. A chemical dosimeter for the determination of the photodynamic activity of photosensitizers. Clinical Chimica Acta, v. 274, n. 1, p. 89-104, 1998.

8 KRALJIC, I. Detection of singlet oxygen and its role in dye-sensitized photooxidation in aqueous and micellar solutions. Biochimie, v. 68, n. 6, p. 807-11, 1986.

9 MARGALIT, R.; ROTENBERG, M. Thermodynamics of porphyrin dimerization in aqueous-solutions. Biochemical Journal, v. 219, n. 2, p. 445-450, 1984.

10 CARREL, A. On the permanent life of tissues outside of the organism. The Jounal of Experimental Medicine, v. 15, n. 5, p. 516-28, 1912.

11 BONNETT, R.; MARTINEZ, G. Photobleaching of sensitisers used in photodynamic therapy. Tetrahedron, v. 57, n. 47, p. 9513-9547, 2001.

12 HOWARD, J. A.; MENDENHALL, G. D. Autoxidation and photooxidation of 1,3diphenylisobenzofuran - kinetic and product study. Canadian Journal of ChemistryRevue Canadienne De Chimie, v. 53, n. 14, p. 2199-2201, 1975.

13 KRALJIC, I.; SHARPATYI, V. A. Determination of singlet oxygen rate constants in aqueous-solutions. Photochemistry and Photobiology, v. 28, n. 4-5, p. 583-586, 1978.

14 LI, A. P. Screening for human ADME/Tox drug properties in drug discovery. Drug Discovery Today, v. 6, n. 7, p. 357-366, 2001. 
15 LOW, K.; KNOBLOCH, T.; WAGNER, S.; WIEHE, A.; ENGEL, A.; LANGER, K.; VON BRIESEN, H. Comparison of intracellular accumulation and cytotoxicity of free mTHPC and mTHPC-loaded PLGA nanoparticles in human colon carcinoma cells. Nanotechnology, v. 22, n. 24, p.1-12, 2011.

16 LI, F.; PARK, S.; LING, D.; PARK, W.; HAN, J. Y.; NA, K.; CHAR, K. Hyaluronic acid-conjugated graphene oxide/photosensitizer nanohybrids for cancer targeted photodynamic therapy. Journal of Materials Chemistry B, v. 1, n. 12, p. 1678-1686, 2013.

17 OLEINICK, N. L.; MORRIS, R. L.; BELICHENKO, T. The role of apoptosis in response to photodynamic therapy: what, where, why, and how. Photochemical \& Photobiological Sciences, v. 1, n. 1, p. 1-21, 2002.

18 BARROS NETO, B. SCARMÍNIO, I. S.; BRUNS, R.E. Como fazer experimentospesquisa e desenvolvimento na ciência e na indústria. 4.ed. Porto Alegre: Bookman, 2010. 414p.

19 BONNETT, R. Photodynamic therapy in historical perspective. Reviews in Contemporary Pharmacotherapy, v. 10, n. 1, p. 1-17, 1999.

20 ALLISON, R.R.; DOWNIE, G.H.; CUENCA, R.; HU, X.H.; CHILDS, C.J.H.; SIBATA, C.H. Photosensitizers in clinical PDT. Photodiagnosis and Photodynamic Therapy, v. 1, n. 1, p. 27-42, 2004.

21 RAAB, O. Effect of fluorescent substances on infusoria. Zeitschrift Fur Biologie, v. 39, n.6, p. 524-546, 1900.

22 ALLISON, R. R.; MOGHISSI, K. Oncologic photodynamic therapy: clinical strategies that modulate mechanisms of action. Photodiagnosis and Photodynamic Therapy, v. 10, n. 4, p. 331-341, 2013.

23 TAMAKI, Y. Prospects for nanomedicine in treating age-related macular degeneration. Nanomedicine, v. 4, n. 3, p. 341-352, 2009.

24 ABRAHAMSE, H. Photodynamic cancer therapy - recent advances. AIP Conference Procedings, v. 1380, n.5, p.5-11 2011.

25 BOZZINI, G.; COLIN, P.; BETROUNI, N.; NEVOUX, P.; OUZZANE, A.; PUECH, P.; VILLERS, A.; MORDON, S. Photodynamic therapy in urology: what can we do now and where are we heading? Photodiagnosis Photodynamic Therapy, v. 9, n. 3, p. 261-73, 2012.

26 KACEROVSKA, D.; PIZINGER, K.; KUMPOVA, M.; CETKOVSKA, P. Genital warts treated by photodynamic therapy. SKINmed: Dematology of the Clinician, v. 6, n. 6, p. 295-7, 2007.

27 NUNEZ, S. C.; RIBEIRO, M. S.; GARCEZ, A. S. PDT- Terapia fotodinâmica antimicrobiana na odontologia. Amsterdan: Elsevier. 2013. 312p. 
28 PEREIRA, D. L. C. D.; GUERRA, P. J.; DI PAULA, C. S. C.; RODRIGUES, B. F.R.; KHOURI, S.; FERREIRA, S. J. Study of photodynamic therapy in the control of isolated microorganisms from infected wounds-an in vitro study. Lasers in Medical Science, v. 29, n. 1, p. 113-20, 2014.

29 MEIRE, M.A.; COENYE, T.; NELIS, H.J.; DE MOOR, R.J. Evaluation of Nd:YAG and Er:YAG irradiation, antibacterial photodynamic therapy and sodium hypochlorite treatment on Enterococcus faecalis biofilms. International Endodontic Jounal, v. 45, n. 5, p. 482-91, 2012.

30 TONNESEN, H.H.; MYSTERUD, I.; KARLSEN, J.; SKULBERG, O.M.; LAANE, C.M.; SCHUMACHER, T. Identification of singlet oxygen photosensitizes in lambs drinking water in an alveld risk area in West Norway. Jounal of Photochemistry and Photobiology B, v. 119, p. 37-45, 2013.

31 SPERANDIO, F. F.; HUANG, Y. Y.; HAMBLIN, M. R. Antimicrobial photodynamic therapy to kill gram-negative bacteria. Recent Patents on Anti-Infective Drug Discovery, v. 8, n. 2, p. 108-20, 2013.

32 JOSEFSEN, L. B.; BOYLE, R. W. Photodynamic therapy and the development of metal-based photosensitisers. Metal Based Drugs, v. 2008, p. 276109-276133, 2008.

33 JUARRANZ, A.; JAEN, P.; SANZ-RODRIGUEZ, F.; CUEVAS, J.; GONZALEZ, $\mathrm{S}$. Photodynamic therapy of cancer. Basic principles and applications. Clinical and Translational Oncology, v. 10, n. 3, p. 148-54, 2008.

34 LEE, T.; ZHANG, X.A.; DHAR, S.; FAAS, H.; LIPPARD, S.J.; JASANOFF, A. In vivo imaging with a cell-permeable porphyrin-based MRI contrast agent. Chemistry \& Biology, v. 17, n. 6, p. 665-673, 2010.

35 KENNEDY, J. C.; MARCUS, S. L.; POTTIER, R. H. Photodynamic therapy (PDT) and photodiagnosis (PD) using endogenous photosensitization induced by 5 aminolevulinic acid (ALA): mechanisms and clinical results. Journal of Clinical Laser Medicine \& Surgery, v. 14, n. 5, p. 289-304, 1996.

36 CAIRNDUFF, F.; STRINGER, M.R.; HUDSON, E.J.; ASH, D.V.; BROWN, S.B. Superficial photodynamic therapy with topical 5-aminolaevulinic acid for superficial primary and secondary skin cancer. British Journal of Cancer, v. 69, n. 3, p. 605-8, 1994.

37 TRUCHUELO, M.T.; PEREZ, B.; FERNANDEZ-GUARINO, M.; MORENO, C.; JAEN-OLASOLO, P. Fluorescence diagnosis and photodynamic therapy for Bowen's disease treatment. Journal of the European Academy of Dermatology and Venereology, v. 28, n. 1, p. 86-93, 2014.

38 XIAO, Y.; WU, Y.J.; ZHANG, W.J.; LI, X.J.; PEI, F.K. Research progress of magnetic resonance imaging contrast agents. Chinese Journal of Analytical Chemistry, v. 39, n. 5, p. 757-764, 2011.

39 LAKOWICZ, J. R. Principles of fluorescence spectroscopy. 3.ed. New York: Springer, 2006. 954p. 
40 ACKROYD, R.; KELTY, C.; BROWN, N.; REED, M. The history of photodetection and photodynamic therapy. Photochemistry and Photobiology, v. 74, n. 5, p. 656-69, 2001.

41 TURRO, N. J. Modern molecular photochemistry. Sausalito: University Science Books, 1991. 614p.

42 STERNBERG, E. D.; DOLPHIN, D.; BRUCKNER, C. Porphyrin-based photosensitizers for use in photodynamic therapy. Tetrahedron, v. 54, n. 17, p. 41514202, 1998.

43 CASTANO, A. P.; DEMIDOVA, T. N.; HAMBLIN, M. R. Mechanisms in photodynamic therapy: part one-photosensitizers, photochemistry and cellular localization. Photodiagnosis and Photodynamic Therapy, v. 1, n. 4, p. 279-293, 2004.

44 CASTANO, A. P.; DEMIDOVA, T. N.; HAMBLIN, M. R. Mechanisms in photodynamic therapy: part two-cellular signaling, cell metabolism and modes of cell death. Photodiagnosis and Photodynamic Therapy, v. 2, n. 1, p. 1-23, 2005.

45 MORTON, C. A. Photodynamic therapy for nonmelanoma skin cancer - and more? Archives of Dermatology, v. 140, n. 1, p. 116-120, 2004.

46 KALKA, K.; MERK, H.; MUKHTAR, H. Photodynamic therapy in dermatology. Journal of the American Academy of Dermatology, v. 42, n. 3, p. 389-413, 2000.

47 MANG, T. S. Lasers and light sources for PDT: past, present and future. Photodiagnosis and Photodynamic Therapy, v. 1, n. 1, p. 43-48, 2004.

48 BROWN, S. B.; TRUSCOTT, T. G. New light on cancer-therapy. Chemistry in Britain, v. 29, n. 11, p. 955-958, 1993.

49 RODER, B.; NATHER, D. Characterization of photobiophysical properties of sensitizers used in photodynamic therapy. Future Trends in Biomedical Applications of Lasers, v. 1525, p. 377-384, 1991.

50 BONNETT, R. Photosensitizers of the porphyrin and phthalocyanine series for photodynamic therapy. Chemical Society Reviews, v. 24, n. 1, p. 19-33, 1995.

51 KUDINOVA, N. V.; BEREZOV, T. T. Photodynamic therapy: search for ideal photosensitizer. Biomed Khim, v. 55, n. 5, p. 558-69, 2009.

52 NYMAN, E. S.; HYNNINEN, P. H. Research advances in the use of tetrapyrrolic photosensitizers for photodynamic therapy. Journal of Photochemistry and Photobiology B-Biology, v. 73, n. 1-2, p. 1-28, 2004.

53 SCHWARTZ, S. K., ABSOLON, K..; VERMUND, H. Some relationships of porphyrins, X-rays and tumours. University of Minnesota Medical Bulletin, v. 27, p.7$8,1955$. 
54 TANAKA, M.; KINOSHITA, M.; YOSHIHARA, Y.; SHINOMIYA, N.; SEKI, S.; NEMOTO, K.; HAMBLIN, M. R.; MORIMOTO, Y. Photodynamic therapy using intraarticular Photofrin for murine MRSA arthritis: biphasic light dose response for neutrophil-mediated antibacterial effect. Lasers in Surgery and Medicine, v. 43, n. 3, p. 221-229, 2011.

55 SHISHKOVA, N.; KUZNETSOVA, O.; BEREZOV, T. Photodynamic therapy in gastroenterology. Jounal of Gastrointestinal Cancer, v. 44, n. 3, p. 251-259, 2013.

56 CALVETE, M. J. F. G., A. T. P. C.; MOURA, N. M. M. Clorinas em terapia fotodinâmica - síntese e aplicações. Revista Virtual de Química, v. 1, n. 2, p. 92-103, 2009.

57 KARIOTI, A.; BILIA, A. R. Hypericins as potential leads for new therapeutics. International Journal of Molecular Sciences, v. 11, n. 2, p. 562-594, 2010.

58 GYENGE, E.B.; HIESTAND, S.; GRAEFE, S.; WALT, H.; MAAKE, C. Cellular and molecular effects of the liposomal mTHPC derivative Foslipos in prostate carcinoma cells in vitro. Photodiagnosis Photodynamic Therapy, v. 8, n. 2, p. 86-96, 2011.

59 SENGE, M. O.; BRANDT, J. C. Temoporfin (Foscan(R), 5,10,15,20-tetra(mhydroxyphenyl)chlorin)--a second-generation photosensitizer. Photochemistry and Photobiology, v. 87, n. 6, p. 1240-1296, 2011.

60 KONAN, Y. N.; GURNY, R.; ALLEMANN, E. State of the art in the delivery of photosensitizers for photodynamic therapy. Journal of Photochemistry and Photobiology B-Biology, v. 66, n. 2, p. 89-106, 2002.

61 SUN, Y.; CHEN, Z.L.; YANG, X.X.; HUANG, P.; ZHOU, X.P.; DU, X.X. Magnetic chitosan nanoparticles as a drug delivery system for targeting photodynamic therapy. Nanotechnology, v. 20, n. 13, p. $135102-135109,2009$.

62 GARCIA-DIAZ, M.; KAWAKUBO, M.; MROZ, P.; SAGRISTA, M. L.; MORA, M.; NONELL, S.; HAMBLIN, M. R. Cellular and vascular effects of the photodynamic agent temocene are modulated by the delivery vehicle. Journal of Controlled Release, v. 162, n. 2, p. 355-363, 2012.

63 TSAI, T.; YANG, Y.T.; WANG, T.H.; CHIEN, H.F.; CHEN, C.T. Improved photodynamic inactivation of gram-positive bacteria using hematoporphyrin encapsulated in liposomes and micelles. Lasers in Surgery and Medicine, v. 41, n. 4, p. 316-322, 2009.

64 KLAJNERT, B.; ROZANEK, M.; BRYSZEWSKA, M. Dendrimers in photodynamic therapy. Current Medicinal Chemistry, v. 19, n. 29, p. 4903-4912, 2012.

65 HAMBLIN, M.R.; MILLER, J.L.; RIZVI, I.; ORTEL, B.; MAYTIN, E.V.; HASAN, T. Pegylation of a chlorin(e6) polymer conjugate increases tumor targeting of photosensitizer. Cancer Research, v. 61, n. 19, p. 7155-62, 2001. 
66 LIMA, A. M.; PIZZOL, C. D..; MONTEIRO, F. B.; CRECZYNSKI-PASA, T. B.; ANDRADE, G. P.; RIBEIRO, A. O.; PERUSSI, J. R. Hypericin encapsulated in solid lipid nanoparticles: phototoxicity and photodynamic efficiency. Jounal of

Photochemistry and Photobiology B, v. 125, p. 146-54, 2013.

67 SCHMITT, F.; JUILLERAT-JEANNERET, L. Drug targeting strategies for photodynamic therapy. Anticancer Agents Medicinal Chemistry Anticancer Agents Med Chem, v. 12, n. 5, p. 500-525, 2012.

68 BJORN, L.; PAPAGEORGIOU, G. C.; BLANKENSHIP, R. E.; GOVINDJEE. A viewpoint: why chlorophyll a? Photosynthesis Research, v. 99, n. 2, p. 85-98, 2009.

69 DE OLIVEIRA, K.T.; MOMO, P.B.; DE ASSIS, F.F.; FERREIRA, M.A.B.; BROCKSOM, T.J. Chlorins: natural sources, synthetic developments and main applications. Current Organic Synthesis, v. 11, n. 1, p. 42-58, 2014.

70 DE OLIVEIRA, K. T.; GOBO, N. R. S.; DE ASSIS, F. F.; BROCKSOM, T. J. Conceitos fundamentais e aplicações de fotossensibilizadores do tipo porfirinas, clorinas e ftalocianinas em terapias fotônicas. Revista Virtual de Química, v. 7, n. 1, p. $26,2015$.

71 DOS SANTOS, F. A. B.; UCHOA, A. F.; BAPTISTA, M. S.; IAMAMOTO, Y.; SERRA, O. A.; BROCKSOM, T. J.; DE OLIVEIRA, K. T. Synthesis of functionalized chlorins sterically-prevented from self-aggregation. Dyes and Pigments, v. 99, n. 2, p. 402-411, 2013.

72 MONTFORTS, F. P. A Directed synthesis of the chlorin system. Angewandte Chemie-International Edition in English, v. 20, n. 9, p. 778-779, 1981.

73 YOU, H.; YOON, H.E.; YOON, J.H.; KO, H.; KIM, Y.C. Synthesis of pheophorbide-a conjugates with anticancer drugs as potential cancer diagnostic and therapeutic agents. Bioorganic \& Medicinal Chemistry, v. 19, n. 18, p. 5383-5391, 2011.

74 BLUM, A.; GROSSWEINER, L. I. Singlet oxygen generation by hematoporphyrinIX, uroporphyrin-I and hematoporphyrin derivative at $546 \mathrm{~nm}$ in phosphate buffer and in the presence of egg phosphatidylcholine liposomes. Photochemistry and Photobiology, v. 41, n. 1, p. 27-32, 1985.

75 REDMOND, R. W.; LAND, E. J.; TRUSCOTT, T. G. Aggregation effects on the photophysical properties of porphyrins in relation to mechanisms involved in photodynamic therapy. Advances in Experimental Medicine and Biology, v. 193, p. 293-302, 1985.

76 ZHANG, L. J.; BIAN, J.; BAO, L. L.; CHEN, H. F.; YAN, Y. J.; WANG, L.; CHEN, Z. L. Photosensitizing effectiveness of a novel chlorin-based photosensitizer for photodynamic therapy in vitro and in vivo. Journal of Cancer Research and Clinical Oncology, v. 140, n. 9, p. 1527-36, 2014.

77 DE ASSIS, F.F.; DE SOUZA, J.M.; ASSIS, B.H.K.; BROCKSOM, T.J.; DE OLIVEIRA, K.T. Synthesis and photophysical studies of a chlorin sterically designed to prevent self-aggregation. Dyes and Pigments, v. 98, n. 1, p. 153-159, 2013. 
78 FREUND, K. B.; MREJEN, S.; GALLEGO-PINAZO, R. An update on the pharmacotherapy of neovascular age-related macular degeneration. Expert Opinion on Pharmacotherapy, v. 14, n. 8, p. 1017-1028, 2013.

79 ORMOND, A. B.; FREEMAN, H. S. Effects of substituents on the photophysical properties of symmetrical porphyrins. Dyes and Pigments, v. 96, n. 2, p. 440-448, 2013.

80 SZLISZKA, E.; CZUBA, Z.P.; KAWCZYK-KRUPKA, A.; SIERON-STOLTNY, K.; SIERON, A.; KROL, W. Chlorin-based photodynamic therapy enhances the effect of tumor necrosis factor-related apoptosis-inducing ligand (TRAIL) in bladder cancer cells. Medical Science Monitor, v. 18, n. 1, p. BR47-53, 2012.

81 WANG, J.; STACHON, T.; EPPIG, T.; LANGENBUCHER, A.; SEITZ, B.; SZENTMARY, N. Impact of photodynamic inactivation (PDI) using the photosensitizer chlorin e6 on viability, apoptosis, and proliferation of human corneal endothelial cells. Graefes Archive for Clinical and Experimental Ophthalmology, v. 251, n. 4, p. 1199-1204, 2013.

82 AGOSTINIS, P.; VANTIEGHEM, A.; MERLEVEDE, W.; DE WITTE, P.A.M. Hypericin in cancer treatment: more light on the way. International Journal of Biochemistry \& Cell Biology, v. 34, n. 3, p. 221-241, 2002.

83 KUBIN, A.; WIERRANI, F.; BURNER, U.; ALTH, G.; GRUNBERGER, W. Hypericin - the facts about a controversial agent. Current Pharmaceutical Design, v. 11, n. 2, p. 233-253, 2005.

84 HADJUR, C.; RICHARD M.J.; PARAT, M.O.; JARDON, P.; FAVIER A. Photodynamic effects of Hypericin on lipid peroxidation and antioxidant status in melanoma cells. Photochemistry and Photobiology, v. 64, n. 2, p. 375-381, 1996.

85 BANO, G.; STANICOVA, J.; JANCURA, D.; MAREK, J.; BANO, M.; ULICNY, J.; STREJCKOVA, A.; MISKOVSKY, P. On the diffusion of Hypericin in dimethylsulfoxide/water mixtures-the effect of aggregation. Journal of Physical Chemistry B, v. 115, n. 10, p. 2417-2423, 2011.

86 MISKOVSKY, P. Hypericin - A new antiviral and antitumor photosensitizer: Mechanism of action and interaction with biological macromolecules. Current Drug Targets, v. 3, n. 1, p. 55-84, 2002.

87 ALTMANN, R.; FALK, H. The deprotonation and protonation equilibria of a Hypericin derivative in aqueous solution. Monatshefte Fur Chemie, v. 128, n. 6-7, p. 571-583, 1997.

88 BARRAS, A.; BOUSSEKEY, L.; COURTADE, E.; BOUKHERROUB, R. Hypericin-loaded lipid nanocapsules for photodynamic cancer therapy in vitro. Nanoscale, v. 5, n. 21, p. 10562-10572, 2013. 
89 HOPFNER, M.; MAASER, K.; THEISS, A.; LENZ, M.; SUTTER, A. P.; KASHTAN, H.; VON LAMPE, B.; RIECKEN, E. O.; ZEITZ, M.; SCHERUBL, H. Hypericin activated by an incoherent light source has photodynamic effects on esophageal cancer cells. International Journal of Colorectal Disease, v. 18, n. 3, p. 239-247, 2003.

90 SOUZA, M. I.; JAQUES, Y. M.; DE ANDRADE, G. P.; RIBEIRO, A. O.; DA SILVA, E. R.; FILETI, E. E.; AVILLA, E. D.; PINHEIRO, M. V. B.; KRAMBROCK, K.; ALVES, W. A. Structural and photophysical properties of peptide micro/nanotubes functionalized with Hypericin. Journal of Physical Chemistry B, v. 117, n. 9, p. 26052614, 2013.

91 ACEDO, P.; STOCKERT, J.C.; CANETE, M.; VILLANUEVA, A. Two combined photosensitizers: a goal for more effective photodynamic therapy of cancer. Cell Death \& Disease, v. 5, p. 2605-2614, 2014.

92 GYENGE, E.B.; FORNY, P.; LUSCHER, D.; LAASS, A.; WALT, H.; MAAKE, C. Effects of Hypericin and a chlorin based photosensitizer alone or in combination in squamous cell carcinoma cells in the dark. Photodiagnosis and Photodynamic Therapy, v. 9, n. 4, p. 321-331, 2012.

93 GYENGE, E. B.; LUSCHER, D.; FORNY, P.; ANTONIOL, M.; GEISBERGER, G.; WALT, H.; PATZKE, G.; MAAKE, C. Photodynamic mechanisms induced by a combination of Hypericin and a chlorin based-photosensitizer in head and neck squamous cell carcinoma cells. Photochemistry and Photobiology, v. 89, n. 1, p. 150$62,2013$.

94 WILKINSON, F.; HELMAN, W. P.; ROSS, A. B. Rate constants for the decay and reactions of the lowest electronically excited singlet-state of molecular-oxygen in solution - an expanded and revised compilation. Journal of Physical and Chemical Reference Data, v. 24, n. 2, p. 663-1021, 1995.

95 PRAMAURO, E.; PELIZZETTI, E. Micelles - a new dimension in analyticalchemistry. Trac-Trends in Analytical Chemistry, v. 7, n. 7, p. 260-265, 1988.

96 CARABIAS-MARTINEZ, R.; RODRIGUEZ-GONZALO, E.; MORENOCORDERO, B.; PEREZ-PAVON, J.L.; GARCIA-PINTO, C.; LAESPADA, E.F. Surfactant cloud point extraction and preconcentration of organic compounds prior to chromatography and capillary electrophoresis. Journal of Chromatography A, v. 902, n. 1, p. 251-265, 2000.

97 FRESHNEY, R. I. Culture of animal cells: a manual of basic technique and specialized. 6.ed. Wiley-Blackwell, 2010. 796p.

98 BORISSEVITCH, I.E.; BORGES, C.P.F.; YUSHMANOV, V.E.; TABAK, M. Localization of dipyridamole molecules in ionic micelles - effect of micelle and drug charges. Biochimica Et Biophysica Acta-Biomembranes, v. 1238, n. 1, p. 57-62, 1995. 
99 SANTIAGO, P.S.; GANDINI, S.C.M.; MOREIRA, L.M.; TABAK, M. Interaction of cationic water-soluble meso-tetrakis(4-N-methylpyridiniumyl)porphyrin (TMPyP) with ionic and nonionic micelles: aggregation and binding. Journal of Porphyrins and Phthalocyanines, v. 12, n. 8, p. 942-952, 2008.

100 TULUMELLO, D. V.; DEBER, C. M. SDS micelles as a membrane-mimetic environment for transmembrane segments. Biochemistry, v. 48, n. 51, p. 12096-12103, 2009.

101 SKOOG, D. A. W., DONALD M.; HOLLER, F. JAMES.; CROUCH, STANLEY R. Fundamentos de química analítica. 8.ed. São Paulo: Thomson Learning, 2006. 999p.

102 PESCITELLI, G.; BARI, L.; BEROVA, N. Application of electronic circular dichroism in the study of supramolecular systems. Chemical Society Reviews, v. 43, n. 15 , p. 5211-5233, 2014.

103 EISFELD, A.; BRIGGS, J. S. The J- and H-bands of organic dye aggregates. Chemical Physics, v. 324, n. 2-3, p. 376-384, 2006.

104 CANNON, J. B. Pharmaceutics and drug delivery aspects of heme and porphyrin therapy. Journal of Pharmaceutical Sciences, v. 82, n. 5, p. 435-446, 1993.

105 SALAS-GARCIA, I.; FANJUL-VELEZ, F.; ORTEGA-QUIJANO, N.; ARCEDIEGO, J.L. Influence of the photosensitizer photobleaching in the propagation of light during photodynamic therapy. SPIE Conference Procedings, v. 8210, 2012.

106 SERGEEVA, N.N.; SHAKER, Y.M.; FINNIGAN, E.M.; MCCABE, T.; SENGE, M.O. Synthesis of hydroporphyrins based on comparative studies of palladiumcatalyzed and non-catalyzed approaches. Tetrahedron, v. 63, n. 50, p. 12454-12464, 2007.

107 CORREA, J.C.; BAGNATO, V.S; IMASATO, H.; PERUSSI, J.R. Previous illumination of a water soluble chlorine photosensitizer increases its cytotoxicity. Laser Physics, v. 22, n. 9, p. 1387-1394, 2012.

108 RUBIN, M. B.; BRASLAVSKY, S. E. Quantum yield: the term and the symbol. A historical search. Photochemical \& Photobiological Sciences, v. 9, n. 5, p. 670-674, 2010.

109 DOUGHERTY, T. J. Photosensitizers: therapy and detection of malignant tumors. Photochemistry and Photobiology, v. 45, n. 6, p. 879-89, 1987.

110 CASTANO, A. P.; DEMIDOVA, T. N.; HAMBLIN, M. R. Mechanisms in photodynamic therapy: Part three- Photosensitizer pharmacokinetics, biodistribution, tumor localization and modes of tumor destruction. Photodiagnosis and

Photodynamic Therapy, v. 2, n. 2, p. 91-106, 2005.

111 GERWECK, L. E.; SEETHARAMAN, K. Cellular pH gradient in tumor versus normal tissue: Potential exploitation for the treatment of cancer. Cancer Research, v. 56, n. 6, p. 1194-1198, 1996. 
112 MAQSOOD, M.I.; MATIN, M.M.; BAHRAMI, A.R.; GHASROLDASHT, M.M. Immortality of cell lines: challenges and advantages of establishment. Cell Biology International, v. 37, n. 10, p. 1038-45, 2013.

113 DENIZOT, F.; LANG, R. Rapid colorimetric assay for cell-growth and survival modifications to the tetrazolium dye procedure giving improved sensitivity and reliability. Journal of Immunological Methods, v. 89, n. 2, p. 271-277, 1986.

114 CARMICHAEL, J.; DEGRAFF, W.G.; GAZDAR, A.F.; MINNA, J.D.;

MITCHELL, J.B. Evaluation of a tetrazolium-based semiautomated colorimetric assay assessment of chemosensitivity testing. Cancer Research, v. 47, n. 4, p. 936-942, 1987.

115 OLIVEIRA, A. L.; SALLES, G. N.; COUCEIRO, J.M.C.; EBNER, C.; SILVA, N.S.; SOARES, C.P. Avaliação da atividade mitocondrial no processo de morte celular em células tumorais de mama após tratamento com Ciclosporina A e Photosan3.

Revista Brasileira de Engenharia Biomédica, v. 29, n. 2, p. 6, 2013.

116 SEBAUGH, J. L. Guidelines for accurate EC50/IC50 estimation. Pharmaceutical Statistics, v. 10, n. 2, p. 128-34, 2011.

117 VANDEGINSTE, B. G. M.; KLAESSENS, J. W. A.; KATEMAN, G. A Chemometric tool for computer-aided decision-making in analytical laboratory management. Trac-Trends in Analytical Chemistry, v. 6, n. 10, p. 252-259, 1987.

118 FERY-FORGUES, S.; LAVABRE, D. Are fluorescence quantum yields so tricky to measure? A demonstration using familiar stationery products. Journal of Chemical Education, v. 76, n. 9, p. 1260-1264, 1999.

119 MUROV, S. L. C., I.; HUG, G. L. Handbook of photochemistry. 2.ed. New York: Marcel Dekker, 1993. 420p.

120 POOLER, J. P.; VALENZENO, D. P. Physicochemical determinants of the sensitizing effectiveness for photooxidation of nerve membranes by fluorescein derivatives. Photochemistry and Photobiology, v. 30, n. 4, p. 491-498, 1979.

121 IQBAL, Z.; OGUNSIPE, A.; NYOKONG, T.; LYUBIMTSEV, A.; HANACK, M.; ZIEGLER, T. Photophysics and photochemistry of octaglucosylated zinc phthalocyanine derivatives. Journal of Porphyrins and Phthalocyanines, v. 16, n. 4, p. 413-422, 2012.

122 ATCC. The Essentials of Life Science Research. Cell lines, 2014. Disponível em: <http://www.atcc.org/Products/Cells_and_Microorganisms/Cell_Lines.aspx>. Acesso em: 05 Jan 2014.

123 HARRISON, M. A. RAE, I. F. General techniques of cell culture. New York: Cambridge University, 1997. 162p.

124 FRESHNEY, R. I. Culture of animal cells. New York: Wiley-Liss, 1994. 486p. 
125 LOWRY, O.H.; ROSEBROUGH, N.J.; FARR, A.L.; RANDALL, R.J. Protein measurement with the folin phenol reagent. Journal of Biological Chemistry, v. 193, n. 1, p. 265-275, 1951.

126 FERREIRA, J.; MENEZES, P.F.C.; KURACHI, C.; SIBATA, C.; ALLISON, R.R.; BAGNATO, V.S. Photostability of different chlorine photosensitizers. Laser Physics Letters, v. 5, n. 2, p. 156-161, 2008.

127 BUTLER, M. Mammalian cell biotechnology: a practical approach. New York: Oxford University, 1991. 245p.

128 CHOU, T. C. H., M. Calcusyn: Windows software for dose effect analysis. Cambridge: Biosoft ,1997.

129 MEIER, P. C. ZÜND, R.E. Statistical methods in analytical chemistry. New York: John Wiley, 1993. 321p.

130 PERCZEL, A.; PARK, K.; FASMAN, G. D. Analysis of the circular-dichroism spectrum of proteins using the convex constraint algorithm - a practical guide.

Analytical Biochemistry, v. 203, n. 1, p. 83-93, 1992.

131 LILLETVEDT, M.; TONNESEN, H.H.; HOGSET, A.; NARDO, L.;

KRISTENSEN, S. Physicochemical characterization of the photosensitizers TPCS2a and TPPS2a 1. Spectroscopic evaluation of drug - solvent interactions. Pharmazie, v. 65 , n. 8 , p. 588-595, 2010.

132 MACDONALD, I. J.; DOUGHERTY, T. J. Basic principles of photodynamic therapy. Journal of Porphyrins and Phthalocyanines, v. 5, n. 2, p. 105-129, 2001.

133 LENCI, F.; ANGELINI, N.; GHETTI, F.; SGARBOSSA, A.; LOSI, A.; VECLI, A.; VIAPPIANI, C.; TARONI, P.; PIFFERI, A.; CUBEDDU, R. Spectroscopic and photoacoustic studies of Hypericin embedded in liposomes as a photoreceptor model. Photochemistry and Photobiology, v. 62, n. 1, p. 199-204, 1995.

134 UZDENSKY, A.B.; IANI, V.; MA, L.W.; MOAN, J. Photobleaching of Hypericin bound to human serum albumin, cultured adenocarcinoma cells and nude mice skin.

Photochemistry and Photobiology, v. 76, n. 3, p. 320-328, 2002.

135 MALKIN, J.; MAZUR, Y. Hypericin derived triplet-states and transients in alcohols and water. Photochemistry and Photobiology, v. 57, n. 6, p. 929-933, 1993.

136 THOMAS, M. J. K. Ultraviolet and visible spectroscopy. 2.ed. New York: John Willey 1996. 229p.

137 DURMUS, M.; AHSEN, V. Water-soluble cationic gallium(III) and indium(III) phthalocyanines for photodynamic therapy. Journal of Inorganic Biochemistry, $\mathrm{v}$. 104 , n. 3, p. 297-309, 2010.

138 SMITH, D. W., H.; WALKER, D.; MANNHOLD, R.; KUBINYI, H. E TIMMERMAN, H. Pharmacokinetics and metabolism in drug design. 3.ed. New York: Wiley Verlag, 2012. 268p. 
139 HUANG, L.; HUANG, Y. Y.; MROZ, P.; TEGOS, G. P.; ZHIYENTAYEV, T.; SHARMA, S. K.; LU, Z.; BALASUBRAMANIAN, T.; KRAYER, M.; RUZIE, C.; YANG, E.; KEE, H. L.; KIRMAIER, C.; DIERS, J. R.; BOCIAN, D. F.; HOLTEN, D.; LINDSEY, J. S.; HAMBLIN, M. R. Stable synthetic cationic bacteriochlorins as selective antimicrobial photosensitizers. Antimicrobial Agents and Chemotherapy, v. 54, n. 9, p. 3834-3841, 2010.

140 MAITI, N. C.; MAZUMDAR, S.; PERIASAMY, N. J- and H-aggregates of porphyrin-surfactant complexes: time-resolved fluorescence and other spectroscopic studies. Journal of Physical Chemistry B, v. 102, n. 9, p. 1528-1538, 1998.

141 MCNAUGHT, A.D.; WILKINSON, A. IUPAC: compendium of chemical terminology. Oxford: Blackwell Scientific, 1997. 450p.

142 RUBIRES, R.; CRUSATS, J.; EL-HACHEMI, Z.; JARAMILLO, T.; LOPEZ, M.; VALLS, E.; FARRERA, J. A.; RIBO, J. M. Self-assembly in water of the sodium salts of meso-sulfonatophenyl substituted porphyrins. New Journal of Chemistry, v. 23, n. 2, p. 189-198, 1999.

143 LILLETVEDT, M.; TONNESEN, H.H.; HOGSET, A.; SANDE, S.A.; KRISTENSEN, S. Evaluation of physicochemical properties and aggregation of the photosensitizers TPCS2a and TPPS2a in aqueous media. Pharmazie, v. 66, n. 5, p. 325$333,2011$.

144 CUNDERLIKOVA, B.; BJORKLUND, E.G.; PETTERSEN, E.O.; MOAN, J. pHdependent spectral properties of HpIX, TPPS2a, mTHPP and mTHPC. Photochemistry and Photobiology, v. 74, n. 2, p. 246-252, 2001.

145 DATTA, A.; DUBE, A.; JAIN, B.; TIWARI, A.; GUPTA, P.K. The effect of pH and surfactant on the aggregation behavior of chlorin p6: a fluorescence spectroscopic study. Photochemistry and Photobiology, v. 75, n. 5, p. 488-94, 2002.

146 FALK, H.; MEYER, J. On the homo-association and heteroassociation of Hypericin. Monatshefte Fur Chemie, v. 125, n. 6-7, p. 753-762, 1994.

147 LAJOS, G.; JANCURA, D.; MISKOVSKY, P.; GARCIA-RAMOS, J.V.;

SANCHEZ-CORTES, S. Surface-enhanced fluorescence and Raman scattering study of antitumoral drug Hypericin: an effect of aggregation and self-spacing depending on $\mathrm{pH}$. Journal of Physical Chemistry C, v. 112, n. 33, p. 12974-12980, 2008.

148 FREEMAN, D.; FROLOW, F.; KAPINUS, E.; LAVIE, D.; LAVIE, G.; MERUELO, D.; MAZUR, Y. Acidic properties of Hypericin and its octahydroxy analog in the ground and excited-states. Journal of the Chemical Society-Chemical Communications, n. 7, p. 891-892, 1994.

149 GANDINI, S.C.M.; YUSHMANOV, V.E.; BORISSEVITCH, I.E.; TABAK, M. Interaction of the tetra(4-sulfonatophenyl)porphyrin with ionic surfactants: Aggregation and location in micelles. Langmuir, v. 15, n. 19, p. 6233-6243, 1999.

150 MISHRA, P. P.; BHATNAGAR, J.; DATTA, A. Fluorescence monitoring of pH dependent complexation of chlorin $\mathrm{p}(6)$ with surfactants. Chemical Physics Letters, v. 386, n. 1-3, p. 158-161, 2004. 
151 GONCALVES, P. J.; CORREA, D. S.; FRANZEN, P. L.; DE BONI, L.; ALMEIDA, L. M.; MENDONCA, C. R.; BORISSEVITCH, I. E.; ZILIO, S. C. Effect of interaction with micelles on the excited-state optical properties of zinc porphyrins and J-aggregates formation. Spectrochimica Acta Part a-Molecular and Biomolecular Spectroscopy, v. 112, p. 309-317, 2013.

152 MOAN, J.; SOMMER, S. Action spectra for hematoporphyrin derivative and Photofrin II with respect to sensitization of human cells in vitro to photoinactivation. Photochemistry and Photobiology, v. 40, n. 5, p. 631-4, 1984.

153 REDDI, E.; JORI, G. Steady-state and time-resolved spectroscopic studies of photodynamic sensitizers - porphyrins and phthalocyanines. Reviews of Chemical Intermediates, v. 10, n. 3, p. 241-268, 1988.

154 FUJINAGA, T.; IZUTSU, K.; ADACHI, T. Polarographic studies of dissolved oxygen in dmso-water mixtures. Bulletin of the Chemical Society of Japan, v. 42, n. 1, p. 140-145, 1969.

155 AGGARWAL, L. P. F.; BAPTISTA, M. S.; BORISSEVITCH, L. E. Effects of $\mathrm{NaCl}$ upon TPPS4 triplet state characteristics and singlet oxygen formation. Journal of Photochemistry and Photobiology a-Chemistry, v. 186, n. 2-3, p. 187-193, 2007.

156 MOAN, J. The photochemical yield of singlet oxygen from porphyrins in different states of aggregation. Photochemistry and Photobiology, v. 39, n. 4, p. 445-449, 1984.

157 CAVALCANTE, R.S.; IMASATO, H.; BAGNATO, V.S.; PERUSSI, J.R. A combination of techniques to evaluate photodynamic efficiency of photosensitizers. Laser Physics Letters, v. 6, n. 1, p. 64-70, 2009.

158 SPILLER, W.; KLIESCH, H.; WOHRLE, D.; HACKBARTH, S.; RODER, B.; SCHNURPFEIL, G. Singlet oxygen quantum yields of different photosensitizers in polar solvents and micellar solutions. Journal of Porphyrins and Phthalocyanines, v. 2, n. 2, p. 145-158, 1998.

159 YOUSSEF, T.; FADEL, M.; FAHMY, R.; KASSAB, K. Evaluation of Hypericinloaded solid lipid nanoparticles: physicochemical properties, photostability and phototoxicity. Pharmaceutical Development and Technology, v. 17, n. 2, p. 177-186, 2012.

160 USUI, Y. Determination of quantum yield of singlet oxygen formation by photosensitization. Chemistry Letters, n. 7, p. 743-744, 1973.

161 HADJUR, C.; LANGE, N.; REBSTEIN, J.; MONNIER, P.; VAN DEN BERGH, H.; WAGNIERES, G. Spectroscopic studies of photobleaching and photoproduct formation of meta(tetrahydroxyphenyl) chlorin (m-THPC) used in photodynamic therapy. The production of singlet oxygen by m-THPC. Journal of Photochemistry and Photobiology B-Biology, v. 45, n. 2-3, p. 170-178, 1998. 
162 VENKATESAN, R.; PERIASAMY, N.; SRIVASTAVA, T. S. Singlet molecularoxygen quantum yield measurements of some porphyrins and metalloporphyrins.

Proceedings of the Indian Academy of Sciences-Chemical Sciences, v. 104, n. 6, p. 713-722, 1992.

163 ZAIA, D. A. M.; ZAIA, C.T.B.V.; LICHTING, J. Determinação de proteínas totais via espectrofometria: vantagens e desvantagens dos métodos existentes. Química Nova, v. 21 , n. 6 , p. $7,1998$.

164 LIMA, A. M. Encapsulação de fotossensibilizadores em nanopartículas lipídicas sólidas para maximização da eficiência fotodinâmica e fototoxicidade. 2013. 95f. Dissertação (Mestrado em Química Analítica e Inorgânica)- Instituto de Química de São Carlos, Universidade de São Paulo, São Carlos, 2013.

165 SONCIN, M.; FABRIS, C.; BUSETTI, A.; DEI, D.; NISTRI, D.; RONCUCCI, G.; JORI, G. Approaches to selectivity in the Zn(II)-phthalocyanine-photosensitized inactivation of wild-type and antibiotic-resistant Staphylococcus aureus.

Photochemical \& Photobiological Sciences, v. 1, n. 10, p. 815-819, 2002.

166 THEODOSSIOU, T.A.; HOTHERSALL, J.S.; DE WITTE, PA; PANTOS, A; AGOSTINIS, P. The multifaceted photocytotoxic profile of Hypericin. Molecular Pharmaceutics, v. 6, n. 6, p. 1775-1789, 2009.

167 KIESSLICH, T.; NEUREITER, D.; ALINGER, B.; JANSKY, G. L.; BERLANDA, J.; MKRTCHYAN, V.; OCKER, M.; PLAETZER, K.; BERR, F. Uptake and phototoxicity of meso-tetrahydroxyphenyl chlorine are highly variable in human biliary tract cancer cell lines and correlate with markers of differentiation and proliferation.

Photochemistry and Photobiology Science, v. 9, n. 5, p. 734-43, 2010.

168 SONG J.; GAO T.; YE M.; BI H.; LIU G. The photocytotoxicity of different lights on mammalian cells in interior lighting system. Jounal of Photochemistry and Photobiology B, v. 117, p. 13-8, 2012.

169 ALSALHI, M.S.; ATIF, M.; ALOBIADI, A.A.; ALDWAYYAN, A.S. A study of the photodynamic effect on cancerous cells. Laser Physics Letters, v. 9, n. 8, p. 611$617,2012$.

170 SASNAUSKIENE, A.; KADZIAUSKAS, J.; VEZELYTE, N,; JONUSIENE, V.; KIRVELIENE, V. Apoptosis, autophagy and cell cycle arrest following photodamage to mitochondrial interior. Apoptosis, v. 14, n. 3, p. 276-286, 2009. 